\title{
CARTOGRAPHIES OF VIOLENCE:
}

WOMEN, MEMORY, AND

THE SUBJECT(S) OF THE "INTERNMENT"

by

Mona Gail Oikawa

A thesis submitted in conformity with the requirements

for the degree of Doctor of Philosophy

Department of Sociology and Equity Studies in Education

Ontario Institute for Studies in Education of the University of Toronto

C Copyright by Mona Gail Oikawa 1999 
Acquisitions and Bibliographic Services

395 Wellington Street Ottawa ON K1A ONA Canada
Bibliothèque nationale du Canada

Acquisitions et services bibliographiques

395, rue Wellington Otawa ON KIA ON4 Canada
The author has granted a nonexclusive licence allowing the National Library of Canada to reproduce, loan, distribute or sell copies of this thesis in microform, paper or electronic formats.

The author retains ownership of the copyright in this thesis. Neither the thesis nor substantial extracts from it may be printed or otherwise reproduced without the author's permission.
L'auteur a accordé une licence non exclusive permettant à la Bibliothèque nationale du Canada de reproduire, prêter, distribuer ou vendre des copies de cette thèse sous la forme de microfiche/film, de reproduction sur papier ou sur format électronique.

L'auteur conserve la propriété du droit d'auteur qui protège cette thèse. $\mathrm{Ni}$ la thèse ni des extraits substantiels de celle-ci ne doivent être imprimés ou autrement reproduits sans son autorisation. 


\title{
CARTOGRAPHIES OF VIOLENCE: \\ WOMEN, MEMORY, AND \\ THE SUBJECT(S) OF THE 'INTERNMENT' \\ Mona Gail Oikawa, Doctor of Philosophy, 1999 \\ Department of Sociology and Equity Studies in Education \\ University of Toronto
}

\begin{abstract}
In this thesis, it is argued that the expulsion of Japanese Canadians from the Canadian west coast and their incarceration, dispossession, and displacement in the 1940s were critical acts in Canadian nation-building. acts that served to further the notion of Canada as a space of white supremacy. These nation-building processes, aimed at producing a hegemonic notion of nation and citizenship, were also intrinsically violent. Yet in order to reproduce the notion of Canada as a benevolent country, violence of such enormous consequence must be forgotten through various processes and the thesis examines how certain representational discourses contribute to the forgetting of the enormity of the violence and its long-term effects.

Through interviews with eleven women who were incarcerated and their daughters, I trace how memory of this history is mobilized and transmitted across generations. Using a contrapuntal spatial analysis, I examine how women describe the spaces of incarceration. I illustrate how memory and subjectivity are heterogeneously and relationally produced through seemingly disparate yet interconnected incarceration sites. I also argue that this production of subjects must be seen as contingent upon interlocking systems of domination and emphasize that hegemonic social relations of white supremacy, male domination, class, heteronormativity, and physical/mental ability arrange subjects relationally and hierarchically.
\end{abstract}


Throughout the thesis, I problematize the predominant notion of the "silent" Japanese Canadian subject. The focus upon the "silent" subject must be critically examined in relation to a racializing and en-gendering Western gaze of domination and the forgetting of the silences of the many non-Japanese Canadians who devised. enforced, witnessed, and benefited from these multiply situated violent practices. The discourse of the "silent" subject is concretely interrogated when I examine the ways in which knowledge of this history is transmitted to children of families who were incarcerated. Also undertaken through this study is an interrogation of the liberal humanist subject underpinning hegemonic notions of nation, citizenship, and subjectivity. This analysis is applied, for example, in illustrating how interpretations of testimonies may presume and reify the liberal subject. The thesis also acknowledges how women contest domination and challenge us to re-imagine the subject, citizenship, and nation. 


\section{ACKNOWLEDGMENTS}

I wish to thank the twenty-one women who allowed me to interview them for this project. For all that they taught me. I am profoundly grateful.

To my parents, who did not witness the completion of this thesis, I am indebted for sharing their histories with me. My father, Emest Yoshio Oikawa, taught me in many ways about the Internment and showed me how to apply this knowledge. I wish to acknowledge my grandmother, Shizu Eguchi, whose life has also informed this work. Her recent passing, in addition to the loss of my parents, has reinforced for me the importance of remembering as an ongoing, living practice.

At the Ontario Institute for Studies in Education/University of Toronto. I had the privilege of working with my thesis supervisor, Sherene Razack. Her support of my work and her critical engagement with my project spurred me on to develop my ideas and undertake the difficult task of writing. I also had the pleasure of working with Kari Dehli and Ruth Roach Pierson. Their insights and constructive comments assisted me during the completion of this thesis. I would also like to acknowledge Kari's generous technical support in the printing of the thesis text. Franca Iacovetta provided helpful suggestions at the thesis defence. Dana Y. Takagi's interest in my research and her recommendations for further areas of investigation have encouraged me to think about continuing my work in other forms and forums.

A special word of thanks to my friend Kirsten Emiko McAllister for our conversations about the content and processes of academic and cultural productionlinked by history and across distance, I have felt less alone in doing this work through knowing her.

Also to be acknowledged are members of my family. I would like to thank my siblings Ed, Diane, Michael, and Rick for their support.

Claudia Lopez's empathetic wisdom was a constant gift. Toshi Oikawa's and Nobuko Oikawa's commitment to community has been inspirational and I have learned much from them. I would also like to acknowledge Roy Miki for encouraging me to undertake research in relation to our community and for his reminders to write poetry. 
For their friendship and critical perspectives, I would like to thank Kerri Sakamoto, Richard Fung, Karin Aguilar-San Juan, Mariana Romo-Carmona, and June Chan. Also extending encouragement during various stages of this project were Karri Yano, Sheila Batacharya, Kristyn Wong-Tam, Leslie Komori, Alice Hom, Yvonne Bobb Smith, and Barbara Heron. Jeanie Stewart provided valuable computer assistance.

I would like to express my appreciation to the members of the Toronto Women's Housing Co-Operative for sustaining a safe living environment and to Trudy Chemin. Sat Dharam Kaur, and Shirley Bellis for their compassionate healthcare.

The research and writing stages of this project were supported through funding from the Social Sciences and Humanities Research Council of Canada, the Ontario Graduate Scholarship program of the Ontario government, the National Association of Japanese Canadians Endowment Fund, and the Canadian Japanese-Mennonite Scholarship awarded by the Mennonite Central Committee Canada, and I am grateful for their financial support. 
Dedication

In memory of my parents

Sally Saeko Eguchi Oikawa (1927-1991) and Ernest Yoshio Clikawa (1917-1992). 


\section{TABle of Contents}

ABSTRACT $\ldots \ldots \ldots \ldots \ldots \ldots \ldots \ldots \ldots \ldots \ldots \ldots \ldots \ldots \ldots \ldots \ldots \ldots \ldots$

ACKNOWLEDGMENTS $\ldots \ldots \ldots \ldots \ldots \ldots \ldots \ldots \ldots \ldots \ldots \ldots \ldots \ldots$ iv

DEDICATION $\ldots \ldots \ldots \ldots \ldots \ldots \ldots \ldots \ldots \ldots \ldots \ldots \ldots \ldots \ldots \ldots \ldots$ vi

PREFACE $\ldots \ldots \ldots \ldots \ldots \ldots \ldots \ldots \ldots \ldots \ldots \ldots \ldots \ldots \ldots \ldots \ldots$ viij

INTRODUCTION $\ldots \ldots \ldots \ldots \ldots \ldots \ldots \ldots \ldots \ldots \ldots \ldots \ldots \ldots \ldots \ldots$

CHAPTER ONE. LANGUAGE OF LIBERALISM, LANGUAGE OF FORGETTING:

A CRITIQUE OF THE LIBERAL CONSTRUCTION OF THE "INTERNMENT" HISTORY . . . . . . . . . . . . . . . .

CHAPTER TWo. DIS-ORIENTING THE GAZE: RE-VIEWING IMAGES OF WOMEN

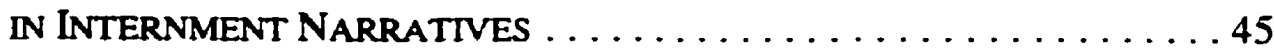

Chapter Three. THERE Is No NAME For THIS: THE DIfFICUl TIES IN REMEMBERING

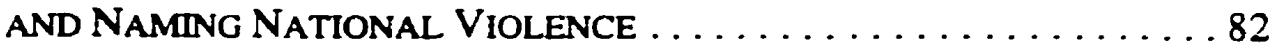

Chapter Four. Cartographies of VIolence: Creating Carceral SPaCes AND EXPELLING JAPANESE CANADLANS FROM THE

NATION SPACE

CHAPTER FIVE. EN-GENDERING THE SUBJECT(S) OF THE INTERNMENT:

THE B.C. INTERIOR PRISON CAMPS $\ldots \ldots \ldots \ldots \ldots \ldots \ldots \ldots \ldots \ldots$

CHAPTER SIX. ECONOMIES OF GENDER: THE "SELF-SUPPORT" INCARCERATIONS. SUGAR BEET FARMS, AND

DOMESTIC WORK

Chapter Seven. The Known and UnKNown: A CommuntTy Lost,

A COMMUNITY REMEMBERED

CHAPTER EIGHT. "IT'S PART OF MY INHERITANCE": HANDING DOWN MEMORY OF THE INTERNMENT

Chapter NINE. "CRUShING THE WhITE WALl WITH OUR Names":

RE-MEMBERING THE INTERNMENT IN WHITE SPACES . . . . . . . . 334

Conclusion. Re-magining Nation, Citizenship, The Subject $\ldots \ldots \ldots 66$

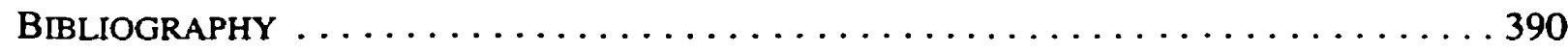




\section{Preface}

In 1985 I commemorated the completion of my master's thesis with the writing of a poem for my grandmother, Shizu Eguchi. It was entitled, "For Shizu."' This poem, filled with despair and a sense of deep prevailing loss, was for me the only appropriate means to express how I felt after years of researching and writing about the mass expulsion and forced resettlement of Japanese Canadians in the 1940s.

Due to the cultural genocide enacted on my family, one of the many consequences of the Canadian government's actions, my grandmother was unable to read this poem because it was written in English and I am unable to write in Japanese, the language which my grandmother is able to read. It was only in 1996, when I finally mustered the courage to ask the editor of a community newspaper to translate it for me, that my grandmother was finally able to read what I had written for her over ten years earlier.

There is no redemption in this telling, no narrative of facile closure. Let me just say that the Internment's shadow looms between us as I sit with my grandmother, now 97 years of age, and follows me through this journey in contemplating its meaning for me and all the women I had the honour to interview in the completion of this project. My need to translate my poem for my grandmother hinged in part on a desire to repair the chasms forged between us through multiple forms of social violence and displacement. I now realize the enormity and impossibility of that task, and deeply question the liberal insistence on language and speech as a remedy to historical trauma. ${ }^{2}$

This thesis is similar to my poem, "For Shizu," in that it has been carried over time, written and re-written, always in the process of becoming, yet incomplete in the articulation that lies before you. Never could it convey the complexity of the memories inspiring its creation nor the lived experiences of those who entrusted me with their re-memberings. My attempts to "translate" my poem for my grandmother reflect in many ways the intranslatability of history and the impossibility of representing the totality of the Internment and its lived effects on generations of women and men. With this awareness of the fissures in my work, I offer it in the hope that the questions I raise will provide openings, challenges, and possibilities for the many communities with whom I live. 


\section{Endnotes: Preface}

1. "For Shizu," was first published in Fireweed 28 (Spring 1989), p. 19.

2. I am using Roger I. Simon and Claudia Eppert's definition (informed by Cathy Caruth) of "historical trauma": "human-initiated, catastrophic events which, when witnessed, often evoke a specific set of experiential dynamics." Simon and Eppert, "Remembering Obligation: Pedagogy and the Witnessing of Testimony of Historical Trauma," Canadian Journal of Education 22, 2 (1997): 176. 


\section{INTRODUCTION}

Thus memory weighs heavily in what I write, in how I begin and in what I find to be significant.

Toni Morrison'

In 1942, the Canadian federal government forcibly removed from their homes 22,000 people of Japanese origin living within a one hundred-mile radius of the Canadian west coast. Many were incarcerated in various sites in British Columbia: prison camps in the B.C. interior, work camps, and so-called self-support communities. Other women, men, and children were sent to work on farms in Alberta and Manitoba. Some men were sent to work camps and prisoner-of-war camps in Ontario. Seventy-five per cent of those forcibly displaced were Canadian citizens. In the United States, over 110,000 Japanese Americans were expelled from the west coast and incarcerated in ten internment camps. ${ }^{2}$

With as little as twenty-four hours notice to move, Japanese Canadians hurriedly sold possessions or gave them to neighbours for safekeeping; property and other possessions were held by the Custodian of Enemy Property. Authorized by the federal cabinet, the Custodian sold all of the chattels and property without the consent of the owners. The government required that the little money acquired through these sales was to be used by each recipient to pay for the expenses of their upkeep in each site. Thus the money acquired from the sale of possessions and property was used to pay for the incarcerations. ${ }^{3}$ From February 1945 to August 1945, the federal government required all Japanese Canadians to sign a "Repatriation Survey," indicating that they would move east of the Rocky Mountains (the province of British Columbia) or be deported to Japan.* Most people were required to make this decision under conditions of incarceration and destitution. Between 31 May 1946 and 24 December 1946, after the war with Japan was over, 3,964 people were deported to Japan; sixty-six per cent were Canadian citizens. ${ }^{5}$ On 1 January 1947, only 6,776 Japanese Canadians remained in the province of British Columbia; over 11,000 people had been forcibly dispersed east of the British Columbia border. ${ }^{6}$ It was not until 1 April 1949 that the last of the federal restrictions imposed upon 
Japanese Canadians were removed and they were allowed to live within the one hundredmile B.C. coastal area. ${ }^{7}$

This study examines how eleven women remember the mass expulsion of Japanese Canadians from the Canadian west coast in the 1940s. It also explores how the subjugated knowledges of this violence are handed down to their daughters and how this history is understood and remembered by them.

This project, however, is less about reconstructing the socio-political events and conditions of this national violence ${ }^{8}$ than it is about understanding how women remember ${ }^{9}$ the violence and how they re-construct themselves in relation to this historical legacy. My work is primarily concerned with how women construct themseives in relation to nation and citizenship through their understandings of what the Internment produced for themselves, their families, and their communities.

While I am cognizant of the fact that I write in a post-redress ${ }^{10}$ context, I suggest that despite this formal "acknowledgment" by the Canadian government the violence of the Internment - its complex iterations and effects - has been largely forgotten. Images of "the Internment," however, have been produced and continue to be commodified. Forgetting is therefore contingent upon active processes of remembering in circumscribed ways. In tracing how the violence is continually being forgotten in various representational forms, I examine in Chapter One how liberal humanist discourses in historical narratives serve to contain the depiction of violence and the subjectivities of the people who were incarcerated. Chapter Two poses the question, "What images of women are produced through these liberal discourses?" and, in particular, interrogates the predominant image of the "silent" survivor" for its raced and gendered significations. Throughout the thesis, I will emphasize the difficulties in naming the violence of the Internment in all its complexities and Chapter Three suggests some of the reasons for the impossibility of naming and begins an examination of some of the discourses used to name the people incarcerated and their sites of incarceration.

I will argue that the Internment was critical to the making of the Canadian nation and citizenship. Violence produced the spaces incarcerating Japanese Canadians and violence was socially produced through these spaces. Women's descriptions of these carceral spaces and what these spaces produced will be the focus of Chapters Four 
through Seven. In these chapters I will also emphasize how systems of domination interlocked in constructing cartographies of violence. Impelled by questions of language and representation, I continue to suggest in Chapter Seven that we problematize our own subject positions in relation to witnessing survivor testimonies and recognize how the liberal subject may be the "real" subject of interpretive cultural production, reified through interpretations of oral testimonies and Internment discourses.

An analysis of the spatialization of knowledge acquisition will be the focus of Chapter Eight as I investigate how children learn about the incarcerations of their families. Chapter Nine continues this inquiry of the relationship of space to knowledge production and concludes by illustrating how women mobilize subjugated knowledges in multiple social contexts.

The conceptualization for this project began while I was completing my master's thesis on the Canadian federal government's policy of forced resettlement of Japanese Canadians to southern Ontario during and after World War $\mathbf{I}^{12}$ During my research for this first major graduate project. I often wondered how the policies described and implemented by the government's bureaucrats affected and were understood by the people and, in particular, the women who experienced them. Compelled by this question and now many years later I am attempting to answer it, in part, by writing this response.

I am conscious that my work is affected by my own experience as a child of families who were the targets of these policies and thus feel it is crucial that I name this at the outset of my work. My need to understand how this history has affected my own life led me to examine how it is remembered across generations of women. When I began to think about interviewing women who had been forcibly moved from the coast, I would often approach women of my own Sansei ${ }^{13}$ generation with my ruminations about what we knew of our parents' histories and how we understood these histories. Inspired through these conversations and by the women in my community, I decided to interview both mothers and daughters in the attempt to understand how we remember this historical legacy.

I realized early on in this work that my own experience differed from what was represented in some of the literature and depictions of this history. In contrast to the many pictures I was presented of "silent" Nisei parents through popular discourse, I never 
considered my parents to be silent about their histories of exclusion. ${ }^{14}$ I was aware at a very early age that my mother had been forced to leave her childhood home in Chemainus, British Columbia (B.C.). This knowledge came to me through our shared ritual of pouring over her photographs strewn in a cardboard suitcase, photos from "camp," a word etched in my memory, always ever associated with a mixture of emotions from her memory of herself as a young woman - grief from loss, joy from friendship, deep regret for the termination of her schooling, fear for the future unknown. All of these conversations were overlaid with a pain that was palpable and yet I remember wanting to be with her in sharing the contents of this container of memory, wanting to know her younger self.

I also knew at a very young age that my father had fought in the war as part of the Allied forces. But military service so usually revered in the Canadian nation as a symbol of citizenship and patriotism seemed incongruent with his experience, which was never acknowledged during our annual Remembrance Day memorials in public school. ${ }^{15}$ I never saw anyone of Dad's likeness shown in the photos of veterans at our school ceremonies or in the crowds at the cenotaph in Ottawa on the evening news. Slowly, my father began over time to fill in these incongruences in my understanding. I learned that my grandmother and most of his siblings spent the war in a "camp" different from my mother's, while he was forced to move to a work camp in Ontario. He eventually voluntarily enlisted after leaving the camp to work in Toronto. I grew up aware of my father's anger at racism and his comparisons of the history of the Internment to other atrocities perpetrated globally.

And while Canada denied my father's role in the military narrative of nation during my childhood years, the public performance of acceptable memory impelled my mother to outfit me with a poppy at the appropriate time each November. I think now that my mother wanted to protect me from the exclusions she had experienced within this nation and thus her provision of the visible mnemonic symbol. Mother, however, in her never-ending struggle to make ends meet, had saved poppies in her sewing cabinet and it was from this stash that she withdrew my annual accessory. I became conscious each year of how a different colour of stamen or a different kind of material would reveal my impostering - I had not put money into the veteran's box that year. So the symbol 
pinned to my lapel took on multiple meanings of my own difference, through the intersections of class, race, and gender, and underlined my non-belonging despite my mother's efforts. I now see my mother's actions as profoundly wise in knowing when to articulate the symbols of the Canadian nation and even in contesting these very practices through her refusal to "buy into" this annual performance in the same way as other "citizens."

The knowledge imparted to me by my parents has thus led to a dissonance: whenever I hear Japanese Canadians described as silent in relation to the Internment, I hear them in those moments where they each articulated and remembered their histories, histories never acknowledged nor taught to me in public school nor undergraduate courses in university. I learned that their utterances of the words "evacuation," "camp," "ghost towns," "Hastings Park," “horse stall," "sugar beets," "Slocan," “Tashme," "work camps" were descriptors for great loss, humiliation, separation, and acknowledgment of the suffering they and others had endured. These words continue to hold these meanings for me and I am reminded of their other resonances when I hear them repeated even in their benign everyday usage. The disjunction between my experience and the discourses that claim to represent my parents' histories has led me to ask questions regarding the containment or homogenization of the subjectivities of those who survived this historical violence.

I continue to live these disjunctive moments when my knowledge of this history meets with the forgetting of this history by non-Japanese Canadians in the different social spaces in which I live. While some might argue that the Internment has been "acknowledged" by the Canadian state and is thus remembered, it is what is remembered and forgotten that are of interest to me in this project. My work suggests that in order to promote an image of Canada as a benevolent country, national violence must be forgotten, and I examine various sites in which this forgetting is actively produced.

In this dissertation, I am attempting to address some of the questions raised by this spectre of the Internment that has affected my life in so many ways and has been a part of my consciousness from a very young age. I reveal my own experience to illustrate the paradox in academic work. While there is a danger in autobiography becoming central to a project in which I have engaged other women's responses to the legacy of the 
Internment, in many ways my own experience is formative in how I have come to think about this history, and I feel it is incumbent on me to reveal this to the reader. Though these cursory self-identifiers are partial signifiers of a shifting subjectivity, they briefly historicize my interpellation as a "Japanese Canadian woman." I would hope that my work will in some way challenge the homogenizing portrayals of "Japanese Canadians" and the Internment, ultimately calling attention to the ways in which domination secures hegemonic notions of the Canadian nation and citizenship, and how women remember and contest these hegemonic practices.

\section{Endnotes: Introduction}

1. Toni Morrison, "The Site of Memory," in Out There: Marginalization and Contemporary Cultures, edited by Russell Ferguson, Martha Gever, Trinh T. Minh-ha, and Cornel West (New York: The New Museum of Contemporary Art; Cambridge, MA: The MIT Press, 1990), p.302.

2. For descriptions of the incarceration of Japanese Americans, see for example, Roger Daniels, Concentration Camps: North America. Japanese in the United States and Canada During World War II (Malabar, FL: Robert E. Krieger, 1981); and Michi Weglyn, Years of Infamy: The Untold Story of America's Concentration Camps (New York: William Morrow, 1976).

3. Ann Gomer Sunahara, The Politics of Racism (Toronto: James Lorimer and Company. $1981)$, p. 105 .

4. Mona Oikawa, " 'Driven to Scatter Far and Wide': The Forced Resettlement of Japanese Canadians to Southern Ontario, 1944-1949," (Master's thesis, University of Toronto, 1986), p.48.

5. Ibid., p.68.

6. Ibid., Appendix One, p.107.

7. Ken Adachi, The Enemy That Never Was: A History of the Japanese Canadians (Toronto: McClelland and Stewart, 1976), p.346. All subsequent references from The Enemy That Never Was are cited from the 1976 edition unless otherwise specified.

8. I use the term "national violence" rather than "political violence" to indicate how this violence was perpetrated to further nation-building. I also wish to emphasize the aspect of complicity through this term, as the violence of the Internment was enacted not by politicians nor the state alone but involved the participation of a nation of citizers in its accomplishment. As I will argue throughout this thesis, white supremacy was secured through the incarceration and displacement of Japanese Canadians, something from 
which all white Canadian citizens variously benefit.

9. I hyphenate the word "remember" to emphasize the embodiment of memory, the very members of the body engaged in remembering, and also the embodiment of others remembered.

10. On 22 September 1988, the federal government signed the redress Agreement negotiated with the National Association of Japanese Canadians. The Agreement included an official acknowledgment, delivered in the House of Commons by Prime Minister Brian Mulroney, that the Government of Canada "wrongfully incarcerated, seized the property, and disenfranchised thousands of citizens of Japanese ancestry." For a description of the redress struggle, see Roy Miki and Cassandra Kobayashi, Justice in Our Time: The Japanese Canadian Redress Settlement (Vancouver: Talonbooks and Winnipeg: National Association of Japanese Canadians, 1991). See pp. 143-144 for the text of the Prime Minister's speech. The Agreement included a payment of $\$ 21,000$ to each survivor born before 1 April 1949 and alive on 22 September 1988. According to Audrey Kobayashi, there were slightly under 17,000 survivors alive at the time the Agreement was signed. Kobayashi, "A Demographic Profile of Japanese Canadians and Social Implications for the Future," Canada: Department of the Secretary of State, September 1989, mimeograph, p.21.

11. Audrey Kobayashi describes how to "most Japanese Canadians" the term "survivor" means "someone who lived through the dispossession of the 1940s." Kobayashi, "A Demographic Profile of Japanese Canadians" p.21. While this term must be further problematized in relation to the Internment, I use it to emphasize the process of living through the expulsion, incarceration, and displacements, and living with the memories of these violences. This inadequate term is chosen over other words used in the literature, for example, "internee," to denote how the subject of the Internment is situated in different times and spaces through a continuing relationship to national violence. I also acknowledge the specific use of the term survivor in relation to the Holocaust and by my use of the term do not intend to equate the Internment with the processes of genocide. For an important critique of the term survivor in relation to the Holocaust, see Lawrence Langer, Admitting the Holocaust (New York and Oxford: Oxford University Press, 1995), p.6.

\section{Mona Oikawa, "Driven to Scatter Far and Wide."}

13. Issei is first generation, Nisei is second, Sansei is third, Yonsei is fourth, Gosei is fifth.

14. For recent examples of visual representations that mobilize the "silence" metaphor, see for example, Anne Wheeler's film, The War Between Us (Canada: Atlantic Films Ltd./Troika Films Ltd., 1995); and the photographic exhibit by Andrew Danson, "Face Kao." "Face Kao" was exhibited at Harbourfront, the Photo Passage, Toronto, MarchMay 1996. It is interesting to note that in separate interviews both Wheeler and Danson invoked the uninterrogated metaphor of "silence" in describing Japanese Canadians. Wheeler commented that Japanese Canadians who were incarcerated "have been very 
quiet about their past." Anne Wheeler, interview by Vicky Gabereau, Canadian Broadcasting Corporation Radio, 7 December 1995. Danson, who discloses that he was married to a Japanese Canadian woman, states, "I asked my wife's family and was met with a wall of silence. The silence was significant." Deidre Hanna, "Andrew Danson's Face Kao Shows Canada's Lack of Honour.” Now, 15, 29 (March 21-27, 1996), p.60.

15. See Lisa Lowe's analysis of the American of Asian descent, "who by definition cannot be imagined as sharing in America" and the contradictions this raises for Asian American and other soldiers of colour. Lisa Lowe, Immigrant Acts (Durham and London: Duke University Press, 1996), pp. 6, 8. For a description of Japanese Canadian men's participation in the Canadian military, see Roy Ito, We Went to War: The Story of the Japanese Canadians Who Served During the First and Second World War (Stittsville, ON: Canada's Wings, 1984). 


\section{Chapter ONe \\ LANGUAGE OF LIBERALISM, LANGUAGE OF FORgETTING: \\ A CrITIQUe Of THE Liberal CONSTRUCTION \\ OF THE “INTERNMENT" HISTORY}

Liberalism plays a foundational part in this process of normalizing and naturalizing racial dynamics and racist exclusions. As modernity's definitive doctrine of self and society, of morality and politics, liberalism serves to legitimate ideologically and to rationalize politico-economically prevailing sets of racialized conditions and racist exclusions.

\section{David Theo Goldberg}

In this thesis I contend that the Internment of Japanese Canadians ${ }^{2}$ must be considered not as antithetical to a liberal democracy such as Canada but as in fact an essential part of Canadian nation-building. One of the terrains upon which the Canadian national discourse is constructed is the historical text and I argue that the reconstruction of the Internment through a liberal historical framework produces homogenized subjects, denied multiple subjectivities, and seeks to essentialize social difference while reifying a particular "Canadian" identity. This liberal construction of the Internment facilitates the process of a national forgetting of the devastation of national violence and its resonating effects. Its reconstruction of "the past" is thus limited to ensuring memory in particularized ways. Its acts of recovering "Japanese Canadian history" are also always about reproducing particular notions of nation and white ${ }^{3}$ dominant subjects. This chapter emphasizes that history is constructed and liberal constructions of the Internment limit our understanding of women's subjectivities in relation to nation, citizenship, and social domination.

Liberalism is understood as capitalist modernity's attachment to certain ideas: individualism, the belief in individuals as rational human beings, and the notion that reform will lead to equality over time. ${ }^{4}$ This philosophical understanding of the inherent rationality of individuals informs particular notions of racism and these will be examined in this chapter. Liberalism also produces a notion of the individual, autonomous subject, a "being without defining limits to community...someone who is not socially constituted."s Further, this concept of the autonomous liberal subject, "functions to suppress our acknowledgment of the profound differences between individuals based on their situation 
within groups and the profound differences between groups." I do not, however, propose the liberal subject as an unchanging essence, but rather seek to understand how this philosophical position informs our understandings of constructions of Japanese Canadian subjects in relation to white subjects. Similarly. I do not propose that Japanese Canadian subjectivities nor white subjectivities are fixed and unchanging.

The liberal construction of history and dominant narratives of nation are promulgated through variegated binary constructions, including that of past and present, citizen and non-citizen. The modernist notion of "continuous progress"7 in the development of Western civilization is the basis for the representation of Canada as an ever-progressing entity. The concept of a progressing nation deploys the pas $/$ present binary in relegating national violences to the underdeveloped moments of the past. While liberalism promotes the notion of transcending social differences, its insistence on "broad identities"8 obfuscates the ways in which difference is complexly constructed and necessary to a white-dominated capitalist nation such as Canada.

It is not suggested that liberalism does not change in its articulation over time nor that contradictory discourses do not occur within this national narrative. Nor is liberalism the only philosophical system that services the production of nation. My intention in this chapter is to illustrate how certain liberal assumptions operate in the writing of the Canadian Internment history and thus produce certain notions of history and its subjects. I also argue that this liberal framework is not only constructing how the Internment history is written and represented, but is always ever present in how we hear/read/see/understand this history and interpret survivor narratives.

Also emphasized in this thesis is the constructedness of the notion of nation. I use Benedict Anderson's conceptualization of the nation as an "imagined political community" in understanding how the Canadian nation is imagined to be a white space and a space of benevolence, emblematically heralded as the "True North Strong and Free." ${ }^{10}$ Despite the hegemonies of these constructions, I also propose that these notions of nation are continually being contested by subordinated communities who engage the space of nation "as a historically produced, unfinished, and contested terrain."

Contesting and negotiating the historical and popular discourses about the Internment are the survivors of these events and their children. It is the objective of my 
work to analyze their complex negotiations through the use of interviews conducted with two generations of women affected by the expulsion, incarcerations, and displacements of the 1940s. Their simultaneously contradictory and contesting remembrances of this history are an indictment of a nation that actively attempts to forget the consequences of social domination and the ways in which it continues to be mobilized in our everyday lives.

My study focuses on the Canadian context and will, therefore, in this chapter mainly address itself to the historical literature that represents this geographically specific experience. I will also utilize some of the critical literature being produced by thinkers investigating the Internment in the United States and draw attention to areas of inquiry being developed in the United States and Canada related to the themes of my project. Because I am interested in how this history has been written, my focus in this chapter is on written historical representations. An analysis of the artistic representations of the Internment, including visual, literary, dance, theatrical, and musical renditions, are beyond the scope of this project. I fear that in drawing these limitations, I may reinscribe the disciplinary boundaries separating the historical, sociological, and the cultural; however, by focusir:g on the historical literature in its most conventional form, my intent is to illustrate how this specific site of knowledge production can reproduce and construct the narratives of nation. In fact, I would suggest that deconstructions and challenges posed by literary and artistic production offer possibilities for powerful counternarratives and expression of heterogeneous subject positions.

It is my contention that much more work needs to be done in critically analyzing this historical violence. Given the multiple sites of exclusion, detention, incarceration, displacement, and forced labour (problematically constrained by the term, "Internment") much more information is required in detailing the conditions of these geographical spaces, their interrelatedness, and how people experienced them. How systems of domination, including white supremacy, male domination. heteronormativity, and ableism figured in the relations of enforcing and experiencing these exclusionary practices must also be further developed.

What is lacking in the historiography is what Elena Tajima Creef calls a "critical examination of the various modes and ideological contents of its representation." 12 
Embedded in this statement is the challenge to the representation of history, a challenge that includes not only a critical examination of how relations of power are written about but also how they inform the ways in which we write. In this chapter I would like to draw attention to the liberal framework of historical writing on the Internment and illustrate how this philosophical position informs not only the conceptualization of history, but also the understandings of social domination, specifically of race. I will conclude by showing what kinds of subjects are proposed within these liberal constructions of the Internment. While the task of this thesis is not to analyze in-depth the historical literature depicting Japanese Canadians, it is my intention to underline how liberal assumptions found in the historiography secure specific narratives of nation.

\section{Liberal Construction of History}

A binary construction mobilized by the liberal historical frame is the clear demarcation between past and present. This results in a national forgetting of the multiple atrocities wreaked by government action and citizen complicity, and the long-term effects these events sustain in the lives of those who lived through them and in subsequent generations. Marita Sturken reminds us that with forgetting are the concomitant acts of remembering and "forgetting of the past in a culture is often highly organized and strategic." ${ }^{13}$ Ernest Renan has also suggested that "forgetting" and even "historical error" are "crucial factor[s] in the creation of a nation." 14

Periodicity is a tool servicing the notion of history as a linear narrative of critical events. It also serves to construct nationhood through its demarcation of landmark nationbuilding moments at the same time as it obfuscates how these narratives foreclose the articulation of different historical markers for communities oppressed by these very constructions of nationhood. Thus when a liberal historical narrative acknowledges the "injustice" perpetrated by a government against its own citizens or communities, it is done by portraying them as rare past moments in an ever progressing country. Hence what becomes articulated is the notion of the possibilities of liberal reform with the promise of equality. This paradigmatic construction serves to isolate victims of state-initiated atrocities from each other and obscures the interconnected relations of domination, 
including colonialism and imperialism, that get structured through processes of nationbuilding.

I have always found troubling and inaccurate the representation of the Internment as a wartime event. In fact, exclusionary legislation against Asians living in British Columbia was enacted from the time of their immigration to Canada and orders-incouncil were executed against Japanese Canadians during and after the war. The war in the Pacific served as a rationale for enacting more and more restrictive and punitive legislation, including the War Measures Act, resulting in the expulsion of $\mathbf{2 2 . 0 0 0}$ Japanese Canadians from the British Columbia west coast, and their incarceration, and dispersal across Canada. In addition, over 4,000 people were deported to Japan. It was only on 1 April 1949 that the last of the federal restrictions against Japanese Canadians were removed and they were allowed to return to the one hundred-mile coastal area of British Columbia. ${ }^{15}$ It was also at this time that the franchise was finally extended to include them. This was almost four years after the end of the Pacific War.

Periodicity emphasizes these events (if they are ever acknowledged) as a corollary to the epical narrative of World War II and in some ways, I would argue, continues to bolster the notion of its military necessity through this semantic association. In fact, I would argue that the violations committed against Japanese Canadians are not emblematic of the war fought in Asia or Europe, but can be more generally seen as an extension of white settler efforts to secure the territories taken from Aboriginal peoples. ${ }^{16}$ Rather than see the Internment as related solely to the war in the Pacific, I would suggest that our temporal gaze be adjusted to view it as reflective of the war for white bourgeois supremacy being waged against people of Japanese origin (and against Aboriginal people and other marginalized communities) living in Canada. Politicians and citizens who supported the expulsion of Japanese Canadians established the zones of this battle spatially by legislating the one hundred-mile restricted area and creating multiple sites of incarceration and forced labour. It was argued by some supporters of this policy that the expulsion of Japanese Canadians was necessary to creating a safe space for non-Japanese Canadians. Such an argument obscures the social relations of the construction of violence of the expulsion: who were the real instigators of violence and how was this violence spatially administered and obscured? As Allen Feldman argues in his analysis of political 
violence in Northern Ireland and the expulsion of people from their homes, "The empty house is a frontier zone and automatically a militarized space." 17

While a comparative study of the Internment and the colonial practices of the English and French colonizers is not possible in this dissertation. I would argue that the technologies utilized against Aboriginal people, including forced displacement, incarceration, segregation, dispossession, destruction of community infrastructures, and separation of families were forerunners to the policing of immigrants, and the eventual formulation and administration of the Internment. Although I would not conflate the processes of colonialism and the Internment as identical, I would stress that it is essential to see them as linked. Care must be taken in our descriptions of the Internment so as not to elide this history of colonialism and ongoing violence waged against Aboriginal people and other marginalized communities in Canada.

In regard to the relationship between Japanese Canadians/Americans and Aboriginal peoples, it is important to note that the Aleuts were also forcibly moved in the 1940 s by the United States government. ${ }^{18}$ More critical research is needed to trace our contrapuntal interrelationships and the specific technology of forced displacement mobilized against many communities in the settler society of Canada. This technology of spatial control operates at a profound level of self-constitution, undermining and often demeaning historically-developed social practices, tearing us away from the spaces in which we engage these practices and sometimes the people with whom we share ways of life and being. As non-Aboriginals who have been displaced from particular geographical spaces to other communities, however, we must also examine our own contradictory positions as "settlers" in relation to the hierarchized arrangements of subjects with whom we share a national context.

Forms of racialized national violence are endemic to the formation of the white Canadian nation. The policing of immigrants and their descendants through the imposition of citizenship criteria that privilege whiteness reproduces the racialized ideal of nationhood. It is such practices of subordination that produce a particular Asian Canadian subjecthood within a liberal nation that promises equality for all. Lisa Lowe comments on the position of Asians in the United States in this way: "As the state legally transforms the Asian alien into the Asian American citizen, it institutionalizes the 
disavowal of the history of racialized labor exploitation and disenfranchisement through the promise of freedom from the political sphere." ${ }^{19}$ In the case of Japanese Canadians, expulsion from the west coast communities was rationalized as a means of excluding the "disloyal," while forcing them to disperse across the country was justified as necessary to the securing of their loyalty.

\section{Re-Viewing The Historical Text}

In this section, I will focus my analysis on The Enemy That Never Was by Ken Adachi; Forrest E. La Violette's The Canadian Japanese and World War II; Mutual Hostages by Patricia Roy, J.L. Granatstein, Masako Lino, and Hiroko Takamura; and Ann Gomer Sunahara's The Politics of Racism. ${ }^{20}$ It is not my intention to portray these historical works dealing with the Internment as a monolithic discourse on these events. Two of the texts, Adachi's The Enemy That Never Was and Sunahara's The Politics of Racism, still most cited in the literature, stand out for their unrivalled accomplishment of writing against an enormous silence in Canadian historical texts. These two works have been foundational in my own understanding of the Internment and its resonating effects and I am indebted to their authors for writing books that continue to encourage and engage a discussion on the significance of this history to our community.

Of the four authors, Ken Adachi is the only Japanese Canadian. The second sentence of his Preface to The Enemy That Never Was, written in 1976, clearly situates himself as "having been the victim since childhood of a particularly virulent strain of racism."21 Adachi undertook writing the history of Japanese Canadians from immigration until the 1970s with this consciousness of racism and a desire to "reveal the demon in its scaly ugliness and perhaps exorcise it." 22 Thus his work was initiated with a critical understanding of the racialized position of Japanese Canadians in relation to the Canadian nation. Adachi's was the first published book on the history of Japanese Canadians, including the Internment years, and was a project that resulted from members of the Japanese Canadian community wanting documentation of their history. ${ }^{23}$ In writing about the Internment - a task that must have been exceedingly painful to Adachi who was a survivor of these events ${ }^{24}$ - he did not have access to government records from this 
period due to the thirty-year restriction placed upon them. He therefore relied upon published material in piecing together one hundred years of history.

Where Adachi was prevented from chronicling the government's internal decision-making processes during the 1940s, Ann Sunahara succeeded in pressuring the federal govemment to release documents for public perusal. This is a singular outstanding achievement but it was furthered by her meticulous outlining of the development of government policy in the 1940 s based upon her analysis of the unrestricted documents. Sunahara situates herself as one of the "Canadians" (to whom, along with "Canadian-born Japanese," she addresses her book) "who have known only a tolerant Canada."2s From these remarks and her unmarked usage of the word "Canadian" as a self-signifier, it can be deduced that Sunahara is white. By contrast to Adachi who situates himself as the subject of racism, Sunahara admits that she has "lived free of racism, and hence in ignorance of its pain and its power." 26 Yet her whiteness does not exclude her from communal social relations with Japanese Canadians and she acknowledges that her husband, David Fumio Sunahara, has taught her about "being Japanese in Canada." 27 I raise these issues of the relationship of the authors to the communities about which and to whom they are writing to reveal the investments that different historians have in the subjects of their work. I do not, however, propose that only Japanese Canadians can write about this history. What is important to me are how relations of domination are constructed through our work and how subjectivities are represented in relation to these systems. "Do historians situate themselves in relation to their project?" and "Whose subjectivities are centred in their work?" are questions that must be entertained when examining how the subjects of their research are represented. I argue that all writers are making disclosures about their own subject positions, even when they do not explicitly amplify them in their work. Their constructions of history, nation, and the subjects of their research are also always about the processes of self-narration and situatedness in the Canadian nation. As Antoinette Burton states, "narratives of the nation... are never 'found' in nature but are always construed by historians for implicit and explicit political purposes and in discrete historical circumstances."28

In the case of Forrest La Violette, his position in relation to his subject is not interrogated, although prefatory remarks by H.F. Angus indicate that La Violette is "Of 
Scottish and French parentage... acquainted with the Orient." ${ }^{29}$ At no time in this book does $\mathrm{La}$ Violette examine his position as a sociology researcher funded by the government in the 1940s to interview Japanese Canadians in the B.C. prison camps. At the very least, the ethics involved in this research relationship should be questioned. Similar research projects conducted in the United States internment camps, the most prominent by Dorothy Swaine Thomas, ${ }^{30}$ have been recently critiqued for their many ethical violations. ${ }^{31}$

Even less information is provided by the authors of Mutual Hostages. In their preface, they identify themselves as "two Canadian historians and two Japanese historians of Canada." 32 Given the way in which the authors use the terms, "Japanese" and "Japanese Canadians" interchangeably in their work to describe people of Japanese origin living in Canada, it is difficult to tell by their prefatory remarks whether the "Japanese" historians are scholars in Japan or Canada. Only from the cover jacket do we confirm that the "Japanese" historians are scholars in Japanese universities.

I would underline that there are differences in the ways in which liberal histories are written and despite claims of objectivity on the part of some academics. relations of power are always embedded in the relationship between historian and the subject of research. This chapter seeks to identify some of the commonalities in the ways in which liberalism is operationalized in the writing of this history. I do not suggest, however, that these books are identical in the ways in which they conceive of the Internment in relation to Japanese Canadians. Clearly for La Violette, The Canadian Japanese and World War II was a sociological project. For Adachi and Sunahara, there was an intent to right a history that had denied the Internment as even occurring. The authors of Mutual Hostages fall far short of their goal to present a complex understanding of the Internment within an international context and in fact rely upon conventional Orientalist constructions of the subject. My intent in examining these texts, however, is not to focus on the "factual" information provided by these histories. Rather, I intend to illustrate how liberal frameworks can shape these "facts" and our understandings of history and its subjects.

Part of the liberal conception of Canadian history positions state-initiated violence as unique events, past mistakes made in a usually tolerant nation. There is also a clear 
demarcation of the past as opposed to the present, indicating that the history of a nation is an ever-progressing one, where equality will be attained over time.

As Donald Nakanishi points out, one of the common renditions of the Intermment in the U.S. literature is that it is "past history." 33 Ann Sunahara takes this position in her prefatory remarks to The Politics of Racism, by stating, "What is past is past...my intention is to tell frankly what the record shows about an unhappy event in Canadian history, an event inconsistent with the public image most Canadians hold of their society." 34 Sunahara's revelations about the critical role of race in determining Canadian government policy and her demonstration that some politicians, civil servants, and military experts held that Japanese Canadians were loyal and should not as an entire community be removed from the coast are an intellectual and political contribution of enormous significance to our community. Yet her emphasis on this history as being a singular "unhappy event" of the past, in both the Preface and Conclusion to her book, act to construct particular notions of Canada. Writing thirty-three years earlier, sociologist, Forrest La Violette, also referred to the Internment history of Japanese Canadians as "the unhappy experiences of British Columbia," 35 thus relegating the Internment to a past geographical and temporal location.

Needless to say, the term "unhappy" does not approach an adequate description of the repressive acts launched against Japanese Canadians in the 1940s and in faimess to these authors, both of these books give detailed accounts of the conditions in multiple sites of exclusion, including the B.C. interior prison camps and the forced labour consignments to sugar beet farmers. Yet the notion that the Internment is incongruent with the usual actions of the Canadian nation is an oft-repeated qualifier of the outrages when admitted. So even in the rare moments where national violence is acknowledged, they are used to further a particular notion of Canada as a "just" and "tolerant" nation.

To illustrate how this phraseology recurs in public remarks marking momentous occasions (particularly for some members of the Japanese Canadian community), we might turn to two examples articulated by Canadian Prime Ministers. In 1964, Lester Pearson, referred to the Internment in this way, at the opening of the Japanese Canadian Cultural Centre in Toronto: "That action by the Canadian government of the day...was a black mark against Canada's traditional fairness and devotion to the principles of human 
rights." ${ }^{36}$ Over twenty years later, in 1988, Prime Minister Brian Mulroney's certificate of "Acknowledgment" to the recipients of the negotiated redress settlement includes his statement: "The acknowledgment of these injustices serves notice to all Canadians that the excesses of the past are condemned and that the principles of justice and equality in Canada are reaffirmed." ${ }^{37}$ Thus Canadian heads of state use the Internment to recuperate liberal notions of Canadian nationhood.

The past/present binary is also mobilized in popular discourse through redemptive narratives emphasizing that Japanese Canadians benefitted from the multiple exclusions and incarceration during the 1940s. These terms and constructions serve to facilitate the forgetting within a nation responsible for the annihilation of a community and the dispersal of its members across the country and to Japan. A phrase that lingers in this popular discourse is that it was a "blessing in disguise." Both Adachi and Sunahara use this term uncritically in describing how "many" Nisei interpret the consequences of the Internment. ${ }^{38}$ Sunahara squarely situates the origins of this phrase within the apologist position that attributes the improvement in the socio-economic status of Japanese Canadians to their displacement from the west coast communities. However. her use of this phrase to describe Nisei as "swallow[ing] the blessing-in-disguise argument without question" 39 illustrates the non-differentiating categorizing that occurs when generalizations are sought about a people or community. The use of this term also renders invisible class and other social differences amongst Japanese Canadians.

When there is actual acknowledgment that harm may have been caused by the Internment, the liberal paradigm is also drawn upon to propose that people can heal from these "unhappy" memories. What is uncertain to me is what actually constitutes "healing" from national violence. I would suggest that it involves "forgetting" à la national amnesia. The healing metaphor in its liberal sense connotes to me an individualized solution to historical trauma and in psychologized forms often not surprisingly emphasizes the means to health as speech.

Feminist historians also struggle with the inclination toward closure in representing the Internment history as it affected women. The notion of female agency can sometimes draw upon the liberal exchange of the rational man for the rational woman. ${ }^{40}$ The liberal notion of history as a linear timeline of progress also informs how 
we write about women's shifting roles and status. In the difficult task of addressing the contradictory shifting social relations between women and men during the Internment, the discourse of progress may impinge upon an articulation of the deleterious effects of the incarceration and who ultimately "progressed," economically and socially, in relation to Japanese Canadians/Americans.

Historian Valerie Matsumoto's historicizing of gender in her examination of the Internment and the Japanese American community in Cortez, California have served as important examples of gender analyses in the historical literature. "I draw attention, however, to her discussion of how the "World War II decade...marked a turning point for Japanese American women in the labour force." 42 In addition, she states, "For Nisei women, like their non-Japanese sisters, the wartime labor shortage opened the door into industrial, clerical, and managerial occupations. ${ }^{.43}$ Although Matsumoto emphasizes that "only 10 percent [of Nisei women] were in domestic service in 1950," Evelyn Nakano Glenn has illustrated that many Issei women and some Nisei women continued to work in the very same job categories that they or their mothers were engaged in prior to and during the Internment. ${ }^{45}$ As Glenn also illustrates, this job sector was not vacated by "Japanese" women as Japanese women married to military personnel undertook paid domestic work upon immigrating to the United States in the post-war period. Matsumoto's comparison of Nisei women to their "non-Japanese sisters" may also serve to elide the differences in their social locations, the coercive context of their employment, and which "doors" had to be opened in order for them to undertake employment.

Glenn's research has provided a ground-breaking analysis of the construction of race, gender, and class in the positioning of Japanese American women as paid domestic workers. In connection to the comment raised about Matsumoto's description of Nisei women's labour, I underline a similar point in relation to Glenn's work. In her book, Issei, Nisei, War Bride, Glenn credits the Internment with changing patriarchal relations with Issei men in her statement: "The internment eroded the political and economic basis of patriarchal authority." ${ }^{46}$ The closed construction of patriarchal relations as only between Japanese Canadian/American men and women is something that I will discuss further in Chapter Two. What Glenn's statement may occlude are women's patriarchal 
relations with non-Japanese American men and in this way may contribute to a reification of the notion of western progress.

Clearly in their work, both Matsumoto and Glenn emphasize that the U.S. exclusionary policies negatively affected Japanese Americans. The concern I raise about the notion of the incarceration or the period of the incarceration as producing "positive changes" is the way in which this discourse is reductively appropriated as individualistic redemptive narratives in popularized discourses on the Internment. These redemptive narratives seek closure and hence a forgetting of the violence of incarceration. The narrative of progress is a key element in the narrative of redemption, eliding the social differences, including colonialism and globalisation of capital, through which the notion of progress is secured. Interrogating the liberal discourse of progress may assist us in keeping our socially-constructed differences in view and in resisting the reification of a notion of "sameness" with the Western liberal subject.

\section{Language of History, Language of the Internment}

Up to this point, my use of the term "Japanese Canadian" has not been problematized. I use it with the consciousness that the term is a historical construction. However, I am also aware that its usage may further the notion of an essentialized "Japanese Canadian" identity, something that I am trying to actively counter in this thesis. My evocation of this term is intended as part of what Laura Hyun Yi Kang invokes as the origin of the term, "Asian American," that of an "oppositional politics," 47 to what is in this geopolitical context, the space of white/Anglo-dominated Canada. Roy Miki emphasizes that the signifier "Japanese Canadian" can be mobilized historically in different ways. Nevertheless, he reminds us that the term "Japanese Canadian," developed administratively through the period of dispersal, also denotes a process of subjectivation promoting a nationalist discourse expressing the desire to "enter the nation's family."

Scholars such as Raymond Okamura have pointed out that the language used by the United States' government to describe their practices of displacing and incarcerating Japanese Americans were euphemisms deliberately chosen to obfuscate "embarrassing or horrible truths." 49 The government coined the terms "evacuation" and "relocation" to describe the forced removal of residents from their homes and their incarceration in 
various sites. Okamura charges that scholars continue to undermine our abilities to conceptualize the atrocities committed by the U.S. government by continuing to use these terms.

Both the terms "evacuation" and "relocation" were also used by the Canadian government to describe the incarceration and displacement of Japanese Canadians. There are also terms specific to Canada that do not exist in the American lexicon due to their different political and administrative strategies, for example, words such as "sugar beet projects," "self-supporting communities," and "repatriation." The liberal notion of choice functions to further the obfuscations of these euphemisms, as the Canadian government emphasized that people "chose" to go to the B.C. prison camps, "self-supporting" communities, or to work on sugar beet farms in Alberta and Manitoba. They also continued this euphemising concept of "choice" when they forced all people of Japanese origin living in Canada to "choose" to go to Japan or "East of the Rockies" by signing the "Repatriation" Survey in 1945. What can become muddied in the use of the government's terminology of "choice" during their enactment of these events are the social conditions of each "choice" and ultimately the fact that all people of Japanese origin were forced from the British Columbia coast.

I would agree with Okamura that a vigilance of language must be attended to in writing about this history. Yet even though he and others have critiqued this euphemistic terminology, as recently as in 1991, Patricia Roy et al. boldly continued to use the term. "evacuation," with no indication of self-reflexivity in their reproduction of this term. I agree with scholar Audrey Kobayashi that these historians "chose" to use this term and this "euphemism should have been put to rest here." 50 Such usage by historians is not an innocent reflection of the past, but serves to re-create a particular benevolent image of the Canadian nation.

Clearly some historians are critical of the practices obfuscated by these misnomers and these critiques are addressed in the literature, especially regarding the use of the term "repatriation." Admittedly, it is difficult to devise terminology that successfully describes the magnitude of these actions, as well as the complexity of the exclusions and violence embedded in multiple actions and sites of incarceration, enforced labour, displacement, and the expulsion of Japanese Nationals and Japanese Canadian citizens to 
Japan. In my work, I have also fallen prey to the need to encapsulate some of these actions with the inadequate and problematic term, "Internment."

I would clarify that I view this term as a composite metonym for the catastrophic event(s) of the 1940s. I am also aware that this term is a contested one. For example, Ann Sunahara points out its specialized legal use and illustrates how the government was careful not to use the term "internment" for Nisei men who were incarcerated in prisonerof-war (POW) camps because "internment under the Geneva Convention is a legal act applicable only to aliens." 52 Yet Sunahara also emphasizes that rather than utilize the government's term "detention," Nisei men who were incarcerated in POW camps continue to refer to their incarceration as "internment." 53 Roy Miki and Cassandra Kobayashi lend a more general use to this term in describing how some Japanese Canadians encapsulate the multiple processes of expulsion from the B.C. coast, "their uprooting and dispossession as internment." 54 Undoubtedly this term is insufficient and its application in denoting an "event," standing in for multiple atrocities, may serve to convey an inaccurate sense of temporal and spatial singularity. ${ }^{55}$ And while I am aware of how the term "Internment" is inadequate to the task of conveying the complex mechanisms of violence enacted against Japanese Canadians, I adopt its application from current community discourses mobilized by some survivors and their children who struggle to name these processes in opposition to the governmental euphemism describing the events as the "evacuation." However, while succumbing to the convenience of using one word to signify catastrophic events in the lives of 22,000 people and emphasizing this sense of catastrophe by capitalizing the " $i$ " of "Internment," I will also try to use space-specific language to describe the actions of expulsion, incarceration, displacement, and forced labour. Chapter Five will demonstrate how some women, while understanding the mobilization of this term to describe the events of the 1940s, will contest its use as a space-specific descriptor. It is my hope that others will name in ways that will better convey the complexity of this history and that we will continue to develop languages within our community that simultaneously engage and encourage criticality in relation to how we represent and are represented by others. ${ }^{56}$

Another attempt to name the violence of the "Internment," is found in the use of the term "uprooting." This term is used in relation to the processes of expelling Japanese 
Canadians to emphasize how they were "rooted" within their communities and were "uprooted" from their home spaces and the space of nation. Lisa Malkki has analyzed how the notion of "uprooting" draws its metaphorical association from constructing the nation as "the land" and "the soil." 57 In attempting to counter the mythology of disloyalty on which the expulsion was based, Japanese Canadians emphasize how generations lived on the west coast and were torn from these communities. The discourse of rootedness reflects the struggle to linguistically affirm loyalty and citizenship, and at the same time denounce the injustice of incarcerating our community. I caution, however, that this arboreal language naturalizes certain entitlements to nation and space and may disguise how "roots" in Canada were procured through colonialism. A notion of "rootedness" may also function to convey a privileging of a propertied class. Kang further analyzes how the term "rootedness" can be mobilized in certain contexts to "confine women 'at home' in the private sphere, in the patriarchal family with its matrix of compulsory heterosexuality, and in terms of a singular ethno-national loyalty - or to exclude them from claiming 'home' in host countries." ${ }^{58}$ Kirsten Emiko McAllister's creative use of the term "deracination" conveys the double meaning of "uprooting" and eradicating people for reasons of "race," yet the etymology of this term is still the "racines" of national belonging. ${ }^{59}$ As I am uncomfortable with the hegemonic resonances of the term, "uprooting," I have chosen not to use it in my work.

I have come to conclude, however, that the struggle to name also engages the liberal demand to speak in a way that is understood by the rational man and rational woman. This debate over which terms we should continue to use and which we should discard are emblematic to me of the difficulties in resisting domination. In attempting to devise a counter-language (and counter-practices), we may encounter other problems of mis-signification. What has become clear to me through this work is that survivors imbue words such as "evacuation" and "internment" with meanings non-survivors may only begin to comprehend. What perhaps must be contended with is the impossibility of articulating the complexity of this history in any language, at the same time as we critically evaluate the social meanings conveyed by the government's euphemisms and our repetition of them. 


\section{Liberal Constructions of Race and Racism}

Racism as a cause of the Intermment is presented in isolation from other systems of domination, with the exception of class in some instances. The predominant analysis of racism in the literature utilizes the social-psychological paradigm of causation resulting from the attitudes of individuals. For example, La Violette states, "knowing as we do the attitudes of British Columbians...demands for their evacuation are the logical outcome." What is highlighted in their "attitudes" toward Japanese Canadians is the "fear" on the part of the white people living in British Columbia. Patricia Roy, J.L. Granatstein, Masako lino, and Hiroko Takamura explain the Internment in this way: "In short, the Canadian government acted largely out of ignorance and in response to public fear." ${ }^{61}$ Roger Daniels echoes this analysis of racism in his 1991 afterword to the second edition of Adachi's The Enemy That Never Was: "their west coast communities were destroyed by a frightened and vindictive government." 62

The individualization of racism is also the hallmark of a liberal discourse where the "rational" individual demonstrates "irrational" fears or errors in judgment. What Julian Henriques points out is this process of situating racism in attitudes ultimately vindicates systems of domination by rationalizing racism as exceptional individual events. ${ }^{63}$ It can also ultimately exonerate racist action by attributing the cause of racism to the perceived "difference" of the subjects, thus holding them responsible for exhibiting "different" conduct or demonstrating a "different culture."

With a liberal analysis of racism, acts of repression are concluded to be the results of individuals' actions. Ann Sunahara attributes the "abuse of Japanese Canadians" to various "villains," including British Columbia Member of Parliament Ian Mackenzie, Vancouver Alderman Halford Wilson, Member of Parliament Humphrey Mitchell and the federal Cabinet. ${ }^{64}$ She also asserts that it was an "ill-informed majority... [that] wreak[ed] havoc on a blameless minority." ${ }^{65}$ It is important to name those who had the power to enact the decisions to destroy the British Columbia Japanese Canadian communities and this is a major contribution of both Sunahara's and Adachi's work. And to their credit, both of the authors name race and racism as part of the ideological construction of the legitimization for the Internment as compared to Roy et al. who centre the concerns of the "fearful" white subject in their work. Focusing on racism, however, as a result of 
ignorance suggests that it is through information that such atrocities will not reoccur. As David Goldberg argues, this solution to racism is infused with the belief that rationality attained through learning will overcome these errors in judgment. ${ }^{66}$ Hence the complex social relations structuring systems of domination and the benefits reaped from these multiple exclusions are denied. In combination with the past/present binary and the claim that reforms will lead to equality, this construction of racism relegates it to a "singular" wrong of the past.

\section{Subjects Produced by Liberal Discourses:}

The Historian As Rational, Objective Subject

The final section of this chapter insists that writers of the Internment history are not only reconstructing narratives and subjects of "the past," but are very much engaging in the construction of the narratives of nation and citizenship. Some examples from the texts in question will illustrate how historians re-make themselves as liberal rational men and women through their claims to objectivity and rationality. It must be emphasized that the making of nation is not only the purview of historians and that there are multivarious discourses contesting and reproducing these constructions, including different engagements by Japanese Canadians.

In 1948, Forrest La Violette was praised by H.F. Angus for not “pass[ing] judgment on the wartime policy of the Canadian government." ${ }^{67}$ In contrast to Ann Sunahara, La Violette's The Canadian Japanese and World War II, written during the 1940s, was not critical of the government's actions. The claim to objectivity of academic writing in this instance is also part of modernity's positivist discourse establishing history and sociology as objective sciences, a contention currently being challenged from multiple sites of knowledge production. The editors of the series that includes Adachi's The Enemy That Never Was are also careful to point out that their "histories are to be objective, analytical, and readable." ${ }^{\circ 8}$ While Sunahara's clear intervention to position the historian as exposer of abuses of government power challenges this traditional view. her mobilization of other liberal conventions, as mentioned above, serve to contain her challenge. 
Nine years after the publication of Sunahara's book, Patricia Roy, Jack Granatstein, Masako Lino, and Hiroko Takamura harken back to H.F. Angus' laudatory remarks on the accomplishment of objectivity in academic production. They preface their book Mutual Hostages with this definition of the historian's "traditional task": "to set out what happened and to try to determine the reasons." They add, "We have sought to explain, not to condone or condemn." ${ }^{69}$ While the authors claim to be writing a more complex history than was written by Ann Sunahara, who explicitly "condemned" the Canadian government's actions, they set up a revealing binary contention in the following statements:

In recent years, some Japanese Canadians have published their own accounts. Joy Kogawa's powerful and popular novel Obasan has had great emotional impact.... We wrote this book with the intention of examining the events of the war years as dispassionately as possible and trying to explain them in the context of their times. Fingers can easily be pointed at historical actors, blame can readily be affixed on politicians and generals, but that would do little to help today's Canadians and Japanese understand the wartime actions of their compatriots and governments. ${ }^{70}$

Thus Roy et al. claim to be "dispassionate" in relation to the "emotional" Japanese Canadians. Their appeal to establishing reason(s) is another flag of liberalism that, in this case, serves to legitimize certain discourses and subject positions as authoritative, relegating "insiders" to the realm of emotional native informants whose passionate, embodied accounts (or ability to engender emotion in others) are cause for exclusion from the stuff of "real" history. " At the same time as "others" are found to be lacking by virtue of their passionate condemnation of the events of the 1940s, these historians gatekeep the boundaries of what is credible history and perform themselves as rational, objective knowledge producers in the liberal paradigm. ${ }^{72}$

What the statements of Roy et al. also obfuscate are their own social locations in relation to the subject and the social construction of history itself. As Audrey Kobayashi states in her review of their book, "The facts do not 'speak for themselves.' they are constructed.... Historians do make value judgements and to deny doing so is uncritical and can be dangerous." Al Although I would argue that passions of various sorts impelled the authors of this work, their claims to dispassion consolidate a re-creation of their rational selves in relation to emotional others. 
It is crucial to underline that, through their prefatory remarks, Roy et al. are responding to the challenges posed by the narrativizing practices of Japanese Canadians, including our mobilization for redress. They credit the redress campaign with keeping the "emotional subject" "in the public conscience."74 Thus, the subjects narrated by others also re-make themselves in multiple sites of knowledge production and even when there are differences in power, the process is never unidirectional. It is also interesting to note how the historians' consciousness of the impact Japanese Canadians have had on the public understanding of the Internment led to this combined effort to shift that understanding.

\section{Japanese Canadian Subjects}

Who are the subjects re-constructed by these various historians? What subjectivities are possible within these liberal containments, where racism and the Internment are relegated to the past and "healing" is the responsibility of the individual? This section will examine how Japanese Canadians are portrayed within these liberal constructions. I would suggest, however, that work needs to be done in analysing the production of subjectivity of those who were in positions to enact legislation and administer the government's exclusionary policies, as well as those who benefited from these policies.

As most of the literature on the Internment focuses on the actions of the government upon Japanese Canadians, there is very little analysis of how these policies were understood and experienced. Thus the contention that the literature constructs a limited repertoire of subject positions for Japanese Canadians, thereby containing them through familiar uninterrogated images. As Nakanishi states, "very little was revealed about how the event adversely affected Japanese Americans... [they] were portrayed as victims, but little was said about their victimization."7s

The subject positions ascribed to Japanese Canadians within the liberal paradigm are limited. Despite the liberal contribution of acknowledging the role of racism in the Internment history, its analysis does not illuminate the complexity of social domination. Portraying Japanese Canadians as an undifferentiated group of people does not allow for an understanding of their heterogeneous and contradictory subject positions. How gender 
operates within the racialized constructions of these exclusionary practices, for example, is not even mentioned in these four historical texts. By the term. gender, $I$ include the construction of female and male subjects and I contend that the liberal narrative does not allow either subject a complex subjectivity.

\section{Citizen Versus Alien/Loyal Versus Disloyal}

Even amongst writers who condemn the actions of the government, there exists a discourse in the arguments of its indefensibility that seeks to minimize "difference" between white Canadians and Japanese Canadians at the time of the war. This occurs in references attesting to the "Canadian" comportment, attitudes, or citizenship of many who were incarcerated. I believe this kind of argumentation can be harmful in that it may obfuscate the historical construction of "difference" and further marginalize those whose differences (i.e., by virtue of class, citizenship, language, religion) distance them from the "Canadian" description assigned to those so identified in the literature. The binary construction of the "Japanese" subject as opposed to the "Canadianized" subject contributes to the reification of a fixed notion of Canadian identity, thereby normalizing a subjectivity of domination. It also reinscribes the boundaries of acceptable identifiers of Canadian citizenship while consolidating notions of outsiders.

This construction is most noticeable when differentiations are made between the Issei and Nisei generations. A disturbing trend I perceive in both the Canadian and American literature is the use of the concepts "culture" and "race" to assign certain characteristics to each generational cohort. These generalizations draw upon fixed notions of Japanese culture, often from what is the Meiji period, to explain what is denoted as "difference" or even "conservatism" amongst the Issei. These cultural explanations are always operating in relation to what is presented as a western or Canadian definition. which is, of course, in binary fashion presented as "progress." Lisa Lowe names these generational comparisons the "privatized familial opposition," a paradigm used to "displace social difference." 76 The tendency in the literature (and in our communities) to generalize characteristics to each generation and speak of them (the Issei, the Nisei, the Sansei) as undifferentiated categories contributes to a monolithic and contained 
construction of all Japanese Canadians, when, in fact, most autobiographical data illustrates heterogeneity across generations.

I believe that the Japanese/Canadian binary is, in part, a response to the spectre of the disloyal Japanese alien mobilized by the federal government in the 1940 s. In order to prove that Japanese Canadians were loyal it is argued by some historians that they were Canadianized and believed in the nation's founding principles. Responding to the mythologized theory of the Japanese enemy in our midst by creating an essentialized notion of Japanese people and Japanese culture furthers categories of difference. Rather than focusing on how people's cultural practices define their loyalty, perhaps we should examine how nationhood excludes certain people from the definition of citizenship.

In seeking to legitimize an exclusionary definition of citizenship in the 1940s, the state mobilized the oppositional positionings of "loyal" and "disloyal" "Japanese" living in Canada, the legislative definitions of which remained in its control. I argue that this haunting spectre of the "disloyal" Japanese Canadian, based upon an Orientalist construction of racial difference, is central to the ways in which the Internment history is written and is an underpinning in the social construction of citizenship in Canada. With the goal of ensuring that British Columbia, and more generally, Canada, remain a whitedominated geographical space, legislative measures were enacted to force Japanese Canadians to leave this province and disperse east of the Rockies.

I believe that it is this spectre of "disloyalty" and its adjunct disentitlement from Canadian citizenship that haunts the historians attempting to write about the Internment. Adachi and Sunahara illustrate how no "acts of disloyalty" were committed by Japanese Canadians or Japanese Nationals living in Canada and they argue that the government's actions were based upon racism and economic opportunism. Roy et al.'s response to Sunahara's work is to argue that there was a "mixture of loyalties uncovered" on the part of Japanese Canadians in their research. 77 This "mixture," however, is presented as proof that the actions of the government were justified. As Yuji Ichioka has suggested "multiple and often conflicting loyalties... [shift] over time and with changing circumstances" and these "complex, ambivalent sentiments and attitudes" must be viewed in relation to subjects' subordinated social positions or "marginality."78 Roy et al.'s fo.zus on "accepting the complexity of motivation... [and] understanding the context and attitudes of a half 
century ago"79 privileges the white bourgeois subject and disallows an understanding of how immigrants and non-white citizens negotiate and struggle with the exclusionary practices of nation. Rather than "exploring how difference is established, how it operates, how and in what ways it constitutes subjects who see and act in the world," these authors use the uninterrogated experiences of Japanese Canadians as "evidence for the fact of difference." ${ }^{80}$ They vindicate the Canadian government by stating that although Canada was committed to "freedom and democracy," "few in Canada before the war had viewed the Japanese Canadians as full citizens. ${ }^{\text {81 }}$ Thus their differential treatment from the stated principles of Canadian citizenship was understandable. Audrey Kobayashi cogently points out: "while the[se] authors go into the fine details of what the Canadian government did because they assumed Japanese Canadians were not real Canadians, they fail to address the belief itself." 82

Roy et al.'s titular syllogism of "Mutual Hostages" feeds upon this notion of the citizen/non-citizen binary. Their argument that "Both wartime Canada and Japan looked on the Japanese and Canadians under their control as mutual hostages." 83 renders equivalent the relationship of Canadian prisoners taken by Japan to that of Japanese Canadians incarcerated by the Canadian government. The fact that these authors fail to convincingly substantiate this thesis in their book is secondary to the way in which their argument demonstrates how they have accepted the assumptions that premise this thesis. While they argue that the Canadian government did not regard Japanese Canadians as citizens and thus disallowed them the rights of citizenship, their own arguments and language continue this disentitlement. For example, their description of Japanese Canadians as "those living among them [real Canadians?] who spoke a different language or merely looked different" relegates them to a marginal status in relation to the "people" of Canada. ${ }^{84}$

\section{Passive, Silent Subjects and Model Minority Subjects}

The liberal framework seeks closure by presenting the Internment as a "past" event. This produces particular kinds of subjects. Predominant images of Japanese Canadians in both the historical literature and in popular discourse are the silent, passive 
subject of Internment, the post-Internment silent survivor, and the Model Minority subject.

Trapped within the discourse of trying to prove the loyalty or (as with Roy et al.) imply the disloyalty of Japanese Canadians within a framework that normalizes the white Canadian subject, contradictory narratives cannot be entertained. Use of testimonies, therefore, must also be limited and contained. What is stunning to me in the literature is the shift from the depiction of protesting Japanese Canadians to a prevailing image of docile people co-operating with the government. As a sociologist who was allowed to interview Japanese Canadians during their incarceration in the B.C. camps, La Violette reported in 1947 that the "Japanese looked upon the whole evacuation as a gross violation of their rights" and consequently made demands and complaints "to administrators in each project, to various officials in Ottawa and to the Spanish Consulate." 85 This compares with Adachi's 1976 account that describes Japanese Canadians as a "relatively docile, co-operative group of victims."

The depiction of Issei and Nisei subjects of the Internment as passive victims translates into the predominant current representation that insists on their silence and unwillingness to speak about their Internment experiences. The prevailing image of the silent Japanese Canadian will be further problematized in Chapter Two, but I would emphasize here that the possibilities for speech are limited within a liberal framework.

That the silence of survivors of the Internment is often associated, at least in part, to their "cultural/racial difference" further signals that the notion of speech is pinned to systems of domination. Such racialization serves to "other" the survivors of historical violence in the eyes of the speaking white rational man within a liberal nation. With an insistence on individual healing and disclosure as a way of dealing with the trauma of oppression, the move to pathologize survivors is a frequent outcome.

The recurring use of the term "shikata ga nai" to describe the "attitude" of people who were incarcerated is also part of this othering narrative. Adachi "translates" this term as "it can't be helped," part of what he constitutes as the "traditional values" imparted to the Nisei by the Issei generation. Used within the context of describing the Nisei as "compliant" and "accepting" of the "outrage of the evacuation," ${ }^{87}$ this essentializing descriptor serves to homogenize the subjectivities of those incarcerated and denies the 
multiple ways in which they negotiated the violence to which they were subjected. That the social reiations constructing the impossibility of translating this term into the dominant language are never attended to in these usages is indicative of how we are implicated in the processes of forgetting the violence of the loss of language and how such violence is complexly negotiated by heterogeneous subjects.

It is important to note that the tendency to pathologize Japanese Canadians occurs both when they do not speak and when they speak. Despite La Violette's reports of the multiple ways in which Japanese Canadians protested the government's actions, he concludes by containing their resistance in statements like the following: "the Japanese were exceedingly hostile towards the government, it became a game for them to make demands, as well as to try to deceive government officials." 88

Characterizations like "hostile" and "deceptive" fit well with the Orientalist construction of the 1940s and it may be argued that La Violette's work is a reflection of this time. What is of interest to me, however, is despite the shifts in the way Japanese Canadians are portrayed, the ultimate reification of the Canadian nation often remains unchallenged. Even sympathetic portrayals of survivors are deeply embedded in constructions that serve to reinforce systems of domination.

Against the image of the pathologized survivor is drawn the success story of the Model Minority. Ann Sunahara offers this characterization of Japanese Canadians and their social context: "individuals have prospered, discrimination has diminished considerably, and Japanese Canadians have earned a reputation as a model minority...."89 And despite the fact that Adachi critiqued the term Model Minority for giving "credence to the notion that racism can be overcome - thus salving the white conscience," by describing the Nisei as "neat, well-dressed, efficient," he does not undermine the homogenizing effects of the label itself. ${ }^{90}$

The specific application of the label "Model Minority" to Japanese Canadians/ Americans gained currency in the 1960 s and continues to the present day. ${ }^{91}$ As Nakanishi explains, this reductive label "portrayed Japanese Americans as having faced seemingly insurmountable racial and economic barriers in the past... but as now exhibiting high aggregate-level indicators of group socio-economic and educational attainment." 92 Although the use of the term, "Model Minority" appears to be more endemic in the 
United States than in Canada, the fact that both Adachi and Sunahara refer to it in their descriptions of Japanese Canadians necessitates some critical engagement with the term.

The Model Minority paradigm reinforces the liberal redemptive narrative of individualism and ahistorical merit-based achievement. In her analysis of how the Canadian educational system uses the concept of the Model Minority in its nondifferentiation amongst "Asian students," Kyo Maclear argues that it results in the denial of social difference and the creation of prescriptive hierarchies for students of colour. In this way, she concludes, the deployment of the concept of Model Minority "amounts to a form of social control" thereby disallowing the notion that students are "complex, diverse, and communicating subjects."93

What these images of passive, silent subject and model minority subject occlude are the relations of power that underpin their construction and the ways in which complex subjectivities are formed within these nexus of power and in relation to other differently located subjects. They also foreclose engagement with contradictory positionings. As Elena Tajima Creef points out, homogeneous constructions "permit little or no room for more complex voices, criticisms, or reflections." What concerns me in addition to how the gaze of domination is produced is, more importantly, how this view affects the ways in which subordinated peoples see ourselves and each other.

\section{Gender and the Subject of the Internment}

As earlier stated, the production of gender through historical accounts of the Internment is not analyzed in any of the four historical texts aforementioned. Where the more recent intervention is made to include Japanese Canadian women in the historical narrative of Canada, it is done by operationalizing the category of gender to describe the origins of patriarchal relations rather than to analyze how gender subordination intersects with other forms of social domination in the construction of subjectivity.

Audrey Kobayashi's careful description of the development of patriarchy during the Meiji period in Japan links gender subordination to the transition from feudal social relations to an ideology of capitalism. Kobayashi's work historicizes culture and explains the social construction of patriarchal relations in the period where most Issei women emigrated to Canada and how these relations affected women's experience in Canada. 
Her presentation of Issei women, however, as, for the most part, a non-differentiated category of women "conditioned" by the roles assigned by Meiji society does not seem to allow for the complex shifts in social relations that she earlier traces in the development of Meiji patriarchy. This homogenizing aspect of her work also serves to reproduce the notion of the fixity of the generational categories, a construction earlier critiqued.

Based on interviews with women who immigrated to Canada before the Internment years, Kobayashi's work reveals that both those who remained in Canada and particularly those who returned to Japan after 1945, reported their feelings of "shame and misery that was caused by their uprooting and dispossession during the 1940s." 95 Importantly, her statement that "generally speaking, those who returned to Japan are bitter about their experiences in Canada"96 as compared to Issei women who remained in Canada as "seldom express[ing] such bitterness" 97 indicates that speech and the ability to be critical about oppression are mediated by the social conditions of one's geopolitical location. In addition, her use of poetry penned by various women and her suggestion that we must understand how patriarchy also depends upon women's emotional attachments within intimate relationships of unequal power alludes to the importance of developing methodologies that undertake an analysis of psychological processes in gender relations.

Midge Ayukawa's work is part of the response to a non-differentiated Japanese Canadian subject and provides compensatory descriptions of some of the conditions endured by Issei women upon immigration to Canada. Her descriptions of how women decided to emigrate and the various reactions and resistances they enacted upon their arrival suggest heterogeneous responses to social oppression. Ayukawa's work is also unique for its description of domestic violence suffered by Issei women as indicative of gender subordination. ${ }^{98}$ However, her conclusion that "most [women] appear to have obeyed their husbands, as good Meiji women were expected to do,"99 continues to fix the notion of unchanging gender relations and does not indicate how women negotiated these relations in a context where dominant models of femininity were not those from Meiji Japan and where other forms of social domination intersected with those of gender.

In addition to Ayukawa's work, various general collections of oral histories include women's testimonies and in one volume, Picture Brides, the recollections of Issei women, inciuding those regarding the Internment, are centred. ${ }^{100}$ However, very little 
work analyzing the gendered experiences of Nisei, Sansei, and Yonsei women exist in the Canadian literature.

One outstanding example of testimony and analysis exists in the work of Muriel Tsukiye Kitagawa, a Nisei woman whose letters to her brother document and analyze the circumstances of her family's expulsion from Vancouver at the time of the war. ${ }^{101} \mathrm{Her}$ correspondence, newspaper articles, and essays present a rare portrait of gender, race, and class relations during and immediately after the destruction of the west coast communities. How Kitagawa's writing is used to represent certain notions of a Japanese Canadian female subject will be examined in Chapter Two.

\section{Conclusion}

In Chapter One, I have analyzed some of the major historical texts representing the Internment and argued that their construction of the Internment as a "past" historical event serves to mask the violence of the expulsion, dispossession. incarceration, and displacement of Japanese Canadians. Not only does the construction of the Internment as a singular past event conceal, through an emphasis on temporality, its complex spatial construction but it also serves to obfuscate its long-term effects in the lives of those who were incarcerated and for subsequent generations. History represented as a march of progress undermines claims for accountability to the people who are harmed through violence as they are reductively forgotten in the turning of the historical page. In such scenarios, like the text of the redress agreement for example. where the Internment has been acknowledged by the state, its construction as a "past" mistake is used to consolidate the notion of the nation as one where benevolence is the rule. Hence, I argue that the construction of history through a liberal temporal discourse serves to contain the violence of the Internment. The "forgetting" of that violence is in fact a continual process of remembering in ways that exonerate those who inhabit the present and negate complicity in the processes of domination - white supremacy, patriarchy, class exploitation, heterosexism, able-bodiedness - upon which "present" privilege is founded.

I would, however, wish to acknowledge the enormous contribution of Ken Adachi and Ann Sunahara in their representations of the Internment history. Their work was critical in lending documentary support to those who fought to win redress from the 
Canadian federal government in the 1980s. It is most disconcerting to realize that at the time of writing this thesis, Sunahara's book, The Politics of Racism, is out-of-print. ${ }^{102}$ How will the limited accessibility of this work further the forgetting of the violence done to Japanese Canadians?

The Japanese Canadian subjects produced through liberal historical reconstructions are limited in demonstrating contradictory and contesting subjectivities. My work will illustrate, however, how the surviving generations of the Internment are the always potentially contradictory memory-bearers challenging a nation's selective amnesia. In the next chapter, I will discuss some representations of women presented in Internment narratives.

\section{Endnotes: Chapter One}

I. David Theo Goldberg, Racist Culture (Cambridge, MA, and Oxford: Blackwell Publishers, 1993), p.l.

2. The term "Japanese Canadian" is used to include both Japanese Nationals and Japanese Canadian citizens living in Canada. This term will be further problematized in this chapter.

3. I use the term "white" to describe what Sherene Razack calls the "colour of domination." She states further that using the "language of colour" emphasizes "the physicality of the encounter between powerful and powerless groups and...the importance of the visible in colonial encounters - who and what is seen and not seen." Razack, Looking White People in the Eye: Gender. Race, and Culture in Courtrooms and Classrooms (Toronto: University of Toronto Press, 1998), p.11. I also use the term with the intent to "mark" the subject of racial dominance at the same time as I often discursively leave unmarked the Japanese Canadian subject. Although this signifier may appear repetitive, I wish to point out that it is usually the "Japanese Canadian" subject who is repetitively racially marked in a text while the white subject remains unmarked. In this way, I hope to contest the normalization of whiteness and the reproduction of racial domination that occur discursively.

4. For an analysis of philosophical liberalism, see Goldberg's Introduction to Racist Culture. See also Sherene Razack's critique of liberalism and its use in law, Canadian Feminism and the Law (Toronto: Second Story Press, 1991), pp.13-16.

5. Sherene Razack, "Collective Rights and Women: 'The Cold Game of Equality Staring.' The Joumal of Human Justice 4,1 (Autumn 1992): 3.

6. Sherene Razack quoted in Razack, Looking White People in the Eye, p.26. 
7. Goldberg, Racist Culture, p.4.

8. Ibid., p.5.

9. Benedict Anderson, Imagined Communities. (London and New York: Verso, 1991), p.6.

10. Rob Shields, Places on the Margin (London and New York: Routledge, 1991), p.61.

11. Aamir Mufti and Ella Shohat, "Introduction," in Dangerous Liaisons, edited by Anne McClintock, Aamir Mufti, and Ella Shohat (Minneapolis and London: University of Minnesota Press, 1997), p.4.

12. Elena Tajima Creef, "Re/Orientations: The Politics of Japanese American Representation" (Ph.D. dissertation, University of California. Santa Cruz, 1994), p.13.

13. Marita Sturken, Tangled Memories (Berkeley: University of California Press, 1997), p.7.

14. Ernest Renan, "What is a Nation?" in Nation and Narration, edited by Homi K. Bhabha (London and New York: Routledge, 1990), p.l I. I would like to thank Ruth Roach Pierson for this reference.

15. Adachi, The Enemy That Never Was, p. 346.

16. For an analysis of Canada as a "settler society," see for example, Daiva Stasiulis and Nira Yuval-Davis, "Introduction: Beyond Dichotomies - Gender, Race, Ethnicity and Class in Settler Societies," in Unsettling Settler Societies, edited by Stasiulis and YuvalDavis (Thousand Oaks, CA and New Dehli: Sage Publications, 1995), pp.1-38.

17. Allen Feldman, Formations of Violence (Chicago and London: University of Chicago Press, 1991), p.26. I would like to thank Kirsten McAllister for informing me of Feldman's work.

18. Gerald D. Berreman describes the forced displacement of Aleuts and the military presence in the Aleutian village of Nikolski in a laudatory fashion: "More recent but effective accultural influences have been the presence of the military and other outside personnel in and around the village since 1957: a period of wartime removal to a good sized town and education outside increased communication with the outside world... and greatly expanded the opportunities to acquire and use a cash income in and out of the village." Berreman, "Aleut Reference Group Alienation, Mobility, and Acculturation," American Anthropologist 66, 2 (1964): 232. Chalsa Loo reports that the United States government offered $\$ 12,000$ to each Aleut survivor as reparation for the ir forced displacement. Loo, "An Integrative-Sequential Treatment Model for Posttraumatic Stress Disorder: A Case Study of the Japanese American Internment and Redress," Clinical Psychology Review 13,2 (1993): 100.

19. Lowe, Immigrant Acts, p.10, emphasis in the original. 
20. Adachi, The Enemy That Never Was; Forrest E. La Violette, The Canadian Japanese and World War II (Toronto: University of Toronto Press, 1948); Patricia Roy, J.L. Granatstein, Masako lino, and Hiroko Takamura, Mutual Hostages: Canadians and Japanese during the Second World War (Toronto: University of Toronto Press, 1990); and Sunahara, The Politics of Racism.

21. Adachi, Preface to The Enemy That Never Was, n.p.

22. Ibid.

23. Ibid.

24. In 1965, Adachi stated in a letter to George Tanaka, "I spent each day in fear and trembling, I was depressed and anxious, guilty and hopeless. The history lay inside my brain, cancerous and eroding." He adds, "I must say this because I want to emphasize what this has cost me...." This letter was written to Tanaka to explain why he was having difficulty writing a chapter for submission to the publisher. It is also revealed in this letter that his original and only copy of a 15,000 word manuscript had been lost. Adachi's letter is found in Roy Ito, Stories of My People, (Hamilton, ON: S-20 and Nisei Veterans Association, 1994), pp.435-437.

25. Sunahara, preface to The Politics of Racism, $x i$.

26. Ibid.

27. Ibid., xii.

28. Antoinette Burton, "Who Needs the Nation? Interrogating 'British' History." Journal of Historical Sociology 10, 3 (September 1997): 235.

29. H.F.Angus, preface to The Canadian Japanese by La Violette, vi.

30. Dorothy Swaine Thomas and Richard S. Nishimoto, The Spoilage: Japanese American Evacuation and Resettlement (Berkeley and Los Angeles: University of California Press, 1946).

31. See Yuji Ichioka, ed., Views from Within: The Japanese American Evacuation and Resettlement Study (Los Angeles: UCLA Asian American Studies Center, 1989).

32. Roy et al., Mutual Hostages, ix.

33. Donald T. Nakanishi, "Surviving Democracy's 'Mistake': Japanese Americans and the Enduring Legacy of Executive Order 9066," Amerasia Journal 19, 1 (1993): 10.

34. Sunahara, The Politics of Racism, xi.

35. La Violette, The Canadian Japanese, p.145. 
36. Lester Pearson quoted in Adachi, The Enemy That Never Was, p.366.

37. Prime Minister Brian Mulroney to Sally Oikawa, "Acknowledgment/

Reconnaissance," n.d., Private collection of Mona Oikawa.

38. Sunahara, The Politics of Racism, p.167, and Adachi, The Enemy That Never Was, pp.361-362.

39. Sunahara, The Politics of Racism, p.167.

40. See Norma Alarcón's critique of the subject of Anglo-American feminism, "The Theoretical Subject(s) of This Bridge Called My Back and Anglo-American Feminism," in Making Face, Making Soul, edited by Gloria Anzaldúa (San Francisco, Aunt Lute Foundation, 1990), especially p.357. I would add that some non-Anglo feminists also make use of the concept of the liberal rational woman.

41. Valerie Matsumoto, "Japanese American Women During World War П," in Unequal Sisters: A Multi-Cultural Reader in U.S. Women's History, edited by Ellen Carol DuBois and Vicki L. Ruiz (New York and London: Routledge, 1990), pp. 373-386,; and Matsumoto, Farming the Home Place: A Japanese American Community in California, 1919-1982 (Ithaca and London: Cornell University Press, 1993).

42. Matsumoto, "Japanese American Women During World War II," p.382.

43. Ibid.

44. Ibid.

45. Evelyn Nakano Glenn, Issei. Nisei, War Bride (Philadelphia: Temple University Press, 1986).

46. Ibid., p.219.

47. Laura Hyun Yi Kang, "Compositional Subjects: Enfiguring Asian/American Women" (Ph.D. dissertation, University of California. Santa Cruz, June 1995), p.5.

48. Roy Miki, Broken Entries: Race, Subjectivity, Writing (Toronto: Mercury Press. 1998), p.194. Miki uses the term "JC" in this collection.

49. Raymond Okamura, "The American Concentration Camps: A Cover-Up Through Euphemistic Terminology," The Journal of Ethnic Studies 10, 3 (Fall 1982): 95.

50. Audrey Kobayashi, review of Mutual Hostages by Roy et al., in B.C. Studies 96 (Winter 1992-93): 118.

51. For an analysis of the term, "repatriation," see Roy Miki. introduction to This is My Own: Letters to Wes \& Other Writings on Japanese Canadians, 1941-1948, by Muriel Kitagawa, edited by Roy Miki (Vancouver: Talonbooks, 1985), p.47. See also Roy Miki 
and Cassandra Kobayashi's analysis of the term, "self-supporting community" in Justice in Our Time (Vancouver: Talonbooks and Winnipeg: National Association of Japanese Canadians, 1991), p.41.

52. Sunahara, The Politics of Racism, p.66.

53. Sunahara describes how Nisei men, incarcerated in POW camps, were identified as being "detained at the pleasure of the Minister of Justice [Louis St. Laurent]." Sunahara. The Politics of Racism, p.66.

54. Miki and Kobayashi, Justice in Our Time, p.24. Miki and Kobayashi use the term "Internment" in their descriptions of the actions of the federal government.

55. In regards to the inadequacy of language, $R$. Ruth Linden discusses how the term "Holocaust" was "not a discrete event with a beginning and end." She quotes Joan Miriam Ringelheim who states, "I would like to suggest that there is no such thing as 'The Holocaust.' What men, women and children experienced was not one event, but a myriad of events which we've tied into an analytic knot so we can speak about it with ease and with single breaths." Linden, Making Stories, Making Selves (Columbus, $\mathrm{OH}$ : Ohio State University Press, 1993), p.86.

56. Roy Miki reminds us that "As the cultural politics of Canada continues to unfold, no doubt terminology will undergo continuing obsolescence. Like sand castles, the words that look good today will (most likely) be swept away by the tides of interrogation." Miki, Broken Entries, (Toronto: Mercury Press, 1998), p.124.

57. Lisa Malkki, "National Geographic: The Rooting of Peoples and the Territorialization of National Identity Among Scholars and Refugees." Cultural Anthropology 7, 1 (February 1992): 24-44.

58. Kang, “Compositional Subjects," p.252.

59. Kirsten Emiko McAllister, "Cultural Production and Alternative Political Practices," (Master's thesis, Simon Fraser University, August 1993), p. I 14.

60. La Violette, The Canadian Japanese, p.43.

61. Roy et.al., Mutual Hostages, $x$.

62. Roger Daniels, afterword to The Enemy That Never Was, by Ken Adachi (Toronto: McClelland and Stewart, 1991), p.371.

63. Julian Henriques, "Social Psychology and the Politics of Racism," in Changing the Subject, by Julian Henriques, et al. (London and New York: Methuen, 1984), p.80.

64. Sunahara, The Politics of Racism, pp.164-165.

65. Ibid., xi. 
66. Goldberg, Racist Culture, see especially Chapter Six.

67. Henry F. Angus, preface to The Canadian Japanese, by La Violette, v. Henry F. Angus was a Professor at the University of British Columbia in the 1940s. He also served on the Standing Committee on Orientals and later moved to Ottawa to work as a special assistant to the Department of External Affairs. See Sunahara, The Politics of Racism, pp. 15,31.

68. Jean Bumet and Howard Palmer, introduction to The Enemy That Never Was, by Adachi, n.p.

69. Roy et al., Mutual Hostages, ix.

70. Ibid., $x i$.

71. See Granatstein and Johnson's contention that their's is a "realist critique of the received version," "The Evacuation of the Japanese Canadians, 1942," in On Guard for Thee: War, Ethnicity, and the Canadian State, 1939-1945, edited by Norman Hillmer, Bohdan Kordan and Lubomyr Luciuk (Ottawa: Minster of Supply and Services Canada, 1988), pp.101-129. Their contention that historians must treat history ai a science is another indication of the liberal foundations of their approach.

72. Another Canadian historian who has criticized Sunahara's work is W. Peter Ward. In 1982, a year after the publication of The Politics of Racism, Ward described the book as "contentious and superficial." Ward also uses the term "evacuation" in his work. Ward. The Japanese in Canada (Ottawa: Canadian Historical Association, 1982), p.21.

73. Audrey Kobayashi, review of Mutual Hostages, p. 120, emphasis in the original. See also Maryka Omatsu's critique of Mutual Hostages in her book, Bittersweet Passage: Redress and the Japanese Canadian Experience (Toronto: Between the Lines, 1992), pp.167-168.

74. Roy et al., Mutual Hostages, xi.

75. Nakanishi, “Surviving," p.14.

76. Lowe, Immigrant Acts, p.63.

77. Roy et al., Mutual Hostages, $x$.

78. Yuji Ichioka, "The Meaning of Loyalty: The Case of Kazumaro Buddy Uno," Amerasia Journal 23, 3 (1997): 56.

79. Ibid., xii.

80. Joan W. Scott, "Experience," in Feminists Theorize the Political (New York and London: Routledge, 1992), p.25. 
81. Roy et al., Mutual Hostages, p.214.

82. Kobayashi, review of Mutual Hostages, p.120, emphasis in the original.

83. Roy et al., Mutual Hostages, ix.

84. Ibid., p.42.

85. La Violette, The Canadian Japanese, p.98.

86. Adachi, The Enemy That Never Was, p.225.

87. Ibid., p.355.

88. La Violette, The Canadian Japanese, p. 106.

89. Sunahara, The Politics of Racism, p.1.

90. Adachi. The Enemy That Never Was, p.356.

91. See Dana Y. Takagi and Lisa Lowe for analyses of the Model Minority ascription. Dana Y. Takagi, The Retreat from Race: Asian-American Admissions and Racial Politics (New Brunswick, NJ: Rutgers University Press, 1992), p.58; and Lowe, Immigrant Acts, p.67.

92. Nakanishi, “Surviving," p.28.

93. Kyo Maclear, "The Myth of the 'Model Minority.' Re-thinking the Education of Asian Canadians," Our Schools/Our Selves 5, 3 (July 1994): 71 . See also Sherene Razack's critique of the Model Minority construct in "The Perils of Talking About Culture: Schooling Research on South and East Asian Students," Race, Gender and Class 2,3 (Spring 1995): 76-77.

94. Creef, "Re/Orientations," p.65.

95. Audrey Kobayashi, "For the Sake of the Children: Japanese/Canadian Workers/ Mothers," in Women, Work, and Place edited by Audrey Kobayashi (Montreal and Kingston: McGill-Queen's University Press, 1994), p.56.

96. Ibid., p.55.

97. Ibid., p.63.

98. Midge Ayukawa, "Good Wives and Wise Mothers: Japanese Picture Brides in Early Twentieth-Century British Columbia," B.C. Studies, 105-106 (Spring [995): 114.

99. Ibid., p.118. 
100. Tomoko Makabe, Picture Brides (Toronto: Multicultural History Society of Ontario, 1995).

101. Muriel Kitagawa, This is My Own. Kitagawa's papers are located in the Manuscript Collection of the National Archives of Canada (hereafter NA).

102. La Violette's The Canadian Japanese is also out-of-print. The second edition of The Enemy That Never Was is still in print. So too is Roy et al.'s Mutual Hostages. 


\title{
Chapter Two \\ DIS-ORIENTING THE GAZE: RE-VIEWING IMAges OF \\ WOMEN IN INTERNMENT NARRATIVES
}

The Asian/American woman is (not) any body, but an effect of discursive constructions located in specific historical moments as well as geopolitical sites.

\author{
Laura Hyun Yi Kang ${ }^{1}$
}

\section{Introduction}

The Internment is a critical thread in the narrativization of the Canadian nation. Although historical attempts are made to relegate it to the past, its recurring narrations necessarily engage and reconstruct notions of nationhood and citizenship. More specifically, the narrators of this history are always in the process of re-inventing themselves, the subjects of the Internment history, and the Canadian nation.

In Chapter One, I outlined how certain historical texts construct liberal notions of the Internment, limiting the ability to view the subjectivities of those who were affected by this historical violence as complex. In Chapter Two. I seek to present some of the predominant images of women in relation to the Internment history. I do so in order to illuminate part of the discursive field in which my project is occurring. This chapter continues the interrogation of the ways in which Japanese Canadian women are constructed in relation to the liberal "Western/Canadian" subject, often as its binary opposite. It introduces my thesis developed in subsequent chapters that the Internment narrative is multiply constituted through hegemonic social relations. Most importantly, it emphasizes that a modernist discourse produces a monolithic notion of community and that a detailed examination of how subjectivity is produced and articulated challenges the essentialist notions of both a unitary "Japanese Canadian" subject and a white Western subject.

\section{Theorizing the Subject}

My project calls for an analysis of the formation of subjectivities in specific geographical and historical contexts, and for a framework that provides us with the possibilities of understanding how power is articulated through these social arrangements. By delineating how relations of power insinuate themselves in complex configurations, 
we might hope to further develop strategies for challenging domination. As Inderpal Grewal states: "It is imperative for us to examine new forms of subjectivity that are radically different from this European imperialist and state-nationalist subject that is binarily constructed and essentialist."2

The work of Michel Foucault has been instrumental in formulating my analysis of how power operates to construct subject positions of domination and subordination. Foucault's project is to understand and articulate these processes; as he states, "we should try to discover how it is that subjects are gradually, progressively, really and materially constituted.... We should try to grasp subjection in its material instance as a constitution of subjects."3

Foucault, however, warns that the notion of "repression" is inadequate for describing these complex social relations and does not capture the "productive aspect of power." This "productive network" insinuates power "through the whole social body": "it traverses and produces things, it induces pleasure, forms knowledge, produces discourse." For Foucault, power is circulated through discourses to produce knowledge and these discursive practices of knowledge production are material and always inscribed in relation to each other. Power, therefore, is "not a property but a relationship" and is always met with "resistance."7 Foucault's analysis therefore suggests that "discourses which constitute the subject are at the same time the condition of possibility of its empowerment."8

Through this discursive process of subject constitution, subjects are "interpellated" or "called to subjectivity by others," a process that is "inherently social." Subjects, therefore, are not "unified, autonomous, individuals exercising free will,"10 as the liberal notion of the subject suggests. Agency or resistance on the part of the subject derives not from denying our "embodiment, relationality, differences, and otherness," but in using our understandings of these constructions as "productive moments."

It is how subordinated subjects negotiate these relations of power that is one of the principal questions posed in this dissertation. Foucault's concept of "subjugated knowledges," "concemed with a historical knowledge of struggles," 12 will be utilized in discussing the testimonies produced by the women interviewed for this project. This examination of women's subjugated knowledges is used to interrogate some of the 
predominant Internment narratives and the ways in which these narrations serve to contain and forget the violence of this historical legacy. In this way, a Foucauldian methodology is mobilized to understand how power constructs the subordinated subject but also to suggest ways in which subjects resist and contest domination.

I take seriously, however, Gayatri Chakravorty Spivak's criticism of Foucault, particularly his concept of "subjugated knowledges" and her pointed admonition that it is impossible to articulate these knowledges via the academic project given the differences in power between the "subjugated" and the researcher. Because of Foucault's failure to address the imperialism constructing the European centrality of his project, Spivak sees him as reproducing the very essentialism of the European subject that he seeks to dismantle. This tension between the structuralist conflating of subjectivity and the desire to reveal the "mechanics of the constitution of the Other"13 exists in my own work where I have used the testimonies of women in a context of unequal power. I would like to underline this tension as a problem integral to the practice of witnessing historical trauma. I also feel strongly that the women I interviewed are always in the process of producing knowledge of the Internment but their knowledge production in this dissertation is mediated by my interventions as interviewer and writer. While an admission of this tension does not abdicate me from the consequences of my own self-privileging discourse, I will attempt to make it visible throughout this project. Although the task of completing this thesis is circumscribed by some of the very systems of power I would like to undermine, I am aware that many of the choices I have made in fashioning this project must be acknowledged as resulting from the privilege bestowed upon me in academic production. I know that there is also a tension in my use of poststructuralism in the theorizing of my project and the, at times, more structuralist demands of political struggle. For example, while I wish to disnupt the essentializing constructions of Japanese Canadians, I also see the necessity in organizing as "Japanese Canadians" to challenge systems of domination.

Foucault's conceptualization of "subjugated knowledges" also does not explicitly address the subordinated social locations of women of colour, a criticism made clearly by Patricia Hill Collins. ${ }^{14}$ Collins does utilize Foucault's concept of subjugated knowledges in her work but she admits that her study presents Black feminist thought as "overly 
coherent" and calls for other thinkers to present the "shifting mosaic of [Black women's] competing ideas and interests."15

I am indebted to Collins and other feminist thinkers who have theorized the subject as produced through the intersections of race, gender, and class. ${ }^{16}$ For Collins, the subordination of Black women is interlocking in the "simultaneity of race, class, and gender oppression." 17 The theory of "interlocking" systems of domination must also address the hegemony of heterosexuality and physical ability. While my project may appear to forefront race and gender, I insist that this methodology can and must be operationalized in understanding how subjectivity is interpellated through all of these systems. For example, in Chapter Five, I illustrate how the removal of men from families during the Internment secured women's gendered role of caring for children. I also argue that the forced removal of men from families by white bourgeois subjects enabled the latter to reproduce a hegemonic family form, the site of white patriarchy and heteronormativity. As I will continue to illustrate in subsequent chapters, through their interlocking, systems of domination enable each other in securing a hierarchy of relational subjects.

In developing my analysis of the gendered and raced constructions of the women's subjectivities in my study, I am drawing upon poststructural critiques of modernity's doctrine of liberalism whose conception of the subject is an essentialized, rational individual. As David Goldberg states: "The philosophical basis of this broad human identity, of an essentially human nature, is taken to lie in a common rational core within each individual, in the (potential) capacity to be moved by Reason." 18 What liberalism does not account for in its claims of individual egalitarianism is how power operates to construct social differences. In critiquing liberalism and its profound influence upon legal discourse, Sherene Razack states, "what this notion most inhibits is our understanding of power as something other than the power of one individual to assert his or her claim over another's." 19 Thus the processes through which power asserts itself in the social construction of subordination and domination are not part of the liberal equation.

What this liberal model of a rational, unified individual also denies are the ways in which subjects have multiple subjectivities that are "not purely rational," and are "potentially contradictory." ${ }^{20}$ As Razack and Meyda Yeğenoğlu suggest, the separation of 
reason from emotion and desire has historically excluded women from the definition of the liberal subject and is antithetical to a feminist position that views women as complex, socially constituted subjects. ${ }^{21}$

As well as interrogating how power is mobilized through the social relations of domination and subordination, poststructuralism also seeks to dismantle the binary oppositions that construct our ways of knowing. For example, some feminist thinkers have criticized feminist work that posits women's undifferentiated oppression in relation to the power of all men or patriarchy. Such a dichotomized analysis of gender obfuscates the social locations of women and men in the experience of different forms of subordination, including race and class. ${ }^{22}$ This bifurcated notion of male domination once again presumes the unified and fixed subject of liberal thought. As Goldberg has illustrated, this stabilization of the Western liberal subject furthers the racist project by promoting fixed identities for those defined as "Others" by the white subject through knowledge production. This includes the construction of racial categories that furnish "social subjects with a cohesive identity...capable of being stretched across time and space."23

My project seeks to disrupt the homogeneous representation of Japanese Canadian women by illustrating the ways in which these differences are constructed through social relations. I realize, however, that this purpose runs counter to the positivist tradition common in the social sciences of seeking similarities from which to make generalizations. Critiquing this practice of knowledge production is also the goal of poststructural deconstruction through an interrogation of the privileging and entrenchment of certain disciplinary knowledges. Despite my resistance to adhering to this hegemonic production of knowledge, however, I know that by virtue of the academic context in which I am writing, I am necessarily engaging in and conforming to certain hierarchical practices of knowledge production. The tension between presenting "Japanese Canadian women" as a group with common interests and as historicallyproduced subjects with divergent, complex subjectivities is one that I will continue to negotiate through this work.

My intent in this chapter is to point out how representations of Japanese Canadian women are mobilized to construct specific notions of the Canadian nation and its citizens. 
Laura Yyun Yi Kang's work has been inspirational in its cogent revelation of the position of Asian women in relation to the United States:

The cultural politics of difference is not a mere inversion of centring the marginalized or an additive project, but one that reveals and contests the contingent, situated strategies of dominant national signification.... Both in her irreducible differences as well as her recent interpellation into "the people," [the Asian/American woman] turns the line of interrogation around and unsettles the finite boundaries of the national address. ${ }^{24}$

In deconstructing the images of women presented in this chapter, my project does not seek to therefore construct the "real" Japanese Canadian woman. Inderpal Grewal reminds us that in order to undermine hegemonic constructions of women of colour, "it is not the resolution of identity that is necessary for political action," rather oppositional practices derive from "the consciousness of the linkages between the specific and multiple hegemonies under which these minorities live."2s

It is my contention that the Internment - its re-constructions, re-memberings and its forgetting - are critical to Canadian nation-building. Although the historical literature outlines the numerous geographical sites to which Japanese Canadians were forced to move, there is little analysis of how this practice of forced dispersal and re-settlement produced particularized subjectivities. Japanese Canadian subjectivities are often seen as fixed. Rey Chow's statement: “Displacement constitutes identity, but as such it is the identity of the ever-shifting"26 challenges this notion of fixity and taps into an understanding that the continual physical and symbolic displacements of Japanese Canadians must involve massive destabilizations of identity. These continual shifts in geographical locations both during and after the 1940s must also be seen as informing the construction of the Canadian nation and white subjects in the multiple sites - the many towns, cities - in which Japanese Canadians were incarcerated, worked, and finally settled. How did their disappearances, appearances, re-appearances in different locations shape the notion of Canadian citizenship both for Japanese Canadians and for those who witnessed their comings and goings? I would argue that these displacements across municipal, provincial, and international boundaries were significant moments in the construction of nation and its citizens. As Lisa Lowe argues, racialized women "contest the normative notion of liberal society" and are "defined by a 'disidentification' with the 
national citizen-subject formation and constituted through lateral movements across distances and disjunctions." 27

The imagining, procuring, and projection of a white-bourgeois dominated nation necessitate violence of various forms and this violence is witnessed through the testimonies garnered from women who were incarcerated. Through multiple spatial displacements, Japanese Canadian women live with the knowledge of the violence done to them, their families, their communities. Women's memories of this violence stand in opposition to the ways in which the nation is publicly enunciated as benevolent and white. Their "disidentification" with narratives of nation, therefore, offer possibilities for contestation of hegemonic notions of the nation, citizenship, and the subject. How Japanese Canadian women re-member these multiple disidentifications will be the focus of this thesis. My argument, developed in this and subsequent chapters wishes to disrupt the totalizing images of Japanese Canadian women as "willing and docile citizen" and racialized "Other," illustrating how they "calibrated the membership criteria of the nationstate." 28

\section{The Problem of Representation}

In conjunction with Chapter One, Chapter Two argues that there is a formulaic reconstruction of the Internment due in part to its liberal humanist underpinnings. What I would like to illustrate in this section is how the liberal subject is also gendered. I will do so by presenting the predominant constructions of women in relation to the Internment. I will, in particular, examine the gendered image of the "silent survivor of Internment." My analysis hinges upon interrogating various images known through popular discourses, including those raised by Joy Kogawa's highly acclaimed novel, Obasan. ${ }^{29}$

Throughout this section, I underline that the images of Japanese Canadians are constructed ones. I would thus like to challenge the notion that the images in circulation are transparent windows to the authentic Japanese Canadian self. I would also like to draw particular attention to the ways in which the generations of Issei, Nisei, and Sansei get solidified through this homogenizing discourse of authentic subject and how the authors of these images are, in fact, re-creating themselves through their representations. 
I know that my own process of selectivity in my methodology is informed by my understanding of the politics of reception. In relation to my critique of the representation of the Internment, I am interested not only in what images are produced but also in the processes through which they are circulated and understood by various audiences. I am deeply aware of how the Internment has been and continues to be commodified, both in academic productions such as this one and through multifarious journalistic and artistic productions. Representation of the Internment is embedded in the very systems of domination that some of these images may seek to disrupt. Any analysis of this representation must keep in mind its process of commodification, and the social and economic interests involved. The notion that the "true" self of the author or the subject can be transparently transmitted denies what Laura Hyun Yi Kang calls the "always already ideologically saturated discursive field that in some ways anticipates the 'self' and re-constructs it." 30

My desire to contribute to the issue of critical engagement among Japanese Canadians on work produced by and about the subject(s) of the Internment may be misconstrued as dissatisfaction with the work generated by friends and colleagues. It is my hope that we would be able to develop creative processes through which we might critically discuss our work more directly as a community of cultural workers and knowledge producers given that in many senses these conversations are occurring through the mediated and distantiated mechanisms of publication and exhibition. As is evident by some of the comments raised by my thesis, I find some of this representation troubling, yet I also view this continuing production as part of a commemorative practice, reflecting our efforts to bear witness to this history and our desire to bring this knowledge to others into the present and future. ${ }^{31}$ While I do not subscribe to the position that any representation authored by Japanese Canadians is necessarily oppositional, what interests me are the narratives used to situate ourselves within historically specific national discourses and how these narrations are understood by us and by non-Japanese Canadians.

I would, however, emphasize my earlier point that production of these discourses engages a complex economy of power and we are variously located in these systems. No representational practice can be an "innocent" one, even if this intentionality is claimed 
by its author (a position related to that of the claim of benevolence). ${ }^{32}$ The questions: "What are we attending to when we bear witness?" and "How do we re-create our selves through these practices?" need to be addressed if we are to develop forms of "just remembrance."33

While the question of explicitly locating our own subject positions in relation to the subject(s) of the Internment is necessary for all of us who attempt to represent it, I would also suggest that non-Japanese Canadians also similarly interrogate their relationship to this history and their investments in its production and in the community they are re-presenting, something I find generally lacking in their work. An obvious lacuna in the work on the Internment authored by non-Japanese Canadians is the investigation of their subject positions or that of their families or forebears during this period. The anthropological gaze toward the "Other" serves to continually obscure the subjectivities of non-Japanese Canadian witnesses, beneficiaries, and enactors of the mechanisms of the Internment.

\section{The Gendered Images of the Silent Subject and the Speaking Subject of the Internment}

I introduced in Chapter One how the predominant images of the silent survivor of the Internment and the Model Minority subject were generated in particular historical texts. In this chapter, I would like to examine how the images of the silent survivor of the Internment and the speaking subject of the Internment are en-gendered through representations of Japanese Canadian women. I will do this by using the novel Obasan by Joy Kogawa as a starting point for the discussion of the prevalent images of women in popular discourse.

The dominant imagery in popular constructions of women and the Internment are those of the binary of "Canadianized" woman and "Oriental" woman. This binary insidiously mediates the ways in which Japanese Canadian women are viewed in relation to each other, that is the "Japanese" woman is always being judged in relation to the "Canadianized" Japanese Canadian woman, the model for which is the white liberal subject. The construction of women also always interlocks with the construction of Japanese Canadian men. 
My use of the critique of Western hegemonic constructions of the "East" draws upon Lisa Lowe's interrogation of Edward Said's concept of Orientalism. ${ }^{34}$ In her work, Lowe points to the necessity of historicizing the concept of Orientalism due to its geographical situatedness and "distinct range of concerns with difference." 35 To trace these expressions of the Orientalized subject as heterogeneously imbricated assists us within the Canadian context to "challenge critical perceptions of a consistent, univocal discourse that dominates, manages, and produces cultural differences...."36 What I wish to do in my work is look at how the Orientalized subject is also gendered by examining the specific representations of women and how women construct themselves in relation to the Internment and the Canadian nation.

The geographically specific Orientalist construction of the subjects of Internment serves the modernist discourse in its quest for closure, the forgetting so integral to the containment of national violence. By focusing upon how the "Other" has coped with the aftermath of the Internment, particularly using the trope of silence to impute an Orientalist understanding of how national violence is negotiated by those who experience it, attention is diverted from the actions of the perpetrators and benefactors of this violence. Orientalism in this national context also attempts to translate the subjects of this violence as members of a unidimensional, "knowable," group whose "racial" and "cultural" characteristics are always ever measured against those of the invisible, unmarked subjects of domination. Such a deflection from an analysis of the systems of domination impinging upon the possibilities for resistance and speech acts, also conveniently limits the understanding of the complex effects of trauma on memory formation.

It is also curious that so little has been written about the "silence/forgetting" of those who witnessed these events. At a recent lecture on photographic images of the American Internment camps presented by Japanese American photographer Masumi Hayashi, a young white woman approached my friend and me, the lone Japanese Canadians in the room. She told us that her mother had been friends with a Japanese Canadian girl in British Columbia and that the friend and her family had to suddenly pack up their things and move. Her mother told her that when she asked her own mother why her friend had to leave, she said, "You must never talk about that." The mother 
remembered that her entire family was told never to talk about the neighbourhood family's sudden departure. The young woman before us wanted to know how she might find her mother's friend because she wanted to put her in touch with her mother. Silences thus are multiply constructed. How this particular family and all those who witnessed the "disappearance" of their neighbours constructed their forgettings is also about their positionality in nation and their relationship to domination.

\section{Obasan}

I cannot bear to open the book's cover. Upon a shelf for years it sits. What lies inside, too painful even to imagine. A naming for things known yet never read. Paradoxically, I "choose" to undertake the study of this literature. Each time the same despairing seizing dread as I attempt to enter another book. A re-embodiment of pain anew.

The contribution of the novel, Obasan, by Joy Kogawa to the representation of the Internment is undeniable. The subject of numerous articles, books, and graduate theses, this novelistic accomplishment has left a lasting legacy upon the literary landscape and has communicated a Canadian Internment narrative to an international audience. ${ }^{37}$ What interests me in addition to the portrayal of women in this novel is the reception given to the novel by critics and readers. To what extent the images in the novel inform the ways in which Japanese Canadians are seen in the Canadian imaginary and nation cannot be determined in this project. But given its resounding impact in terms of the literary criticism generated from its publication alone, I would propose that the readings of this novel are informing present-day notions of the subjects of the Internment history. At the very least, Obasan's currency and reconstitution by critics, scholars, artists, educators, and journalists are part of the environment of the women I have interviewed and they necessarily must position themselves in relation to this narrative. Even the not-reading of the novel by Japanese Canadians is an experience of relationality to the work given the awareness that the novel has been much acclaimed and deals with the Internment.

My intention in this section is not to critically engage a textual analysis of Obasan. Rather, I propose to use it as a starting point for discussing the popularization of certain images of Japanese Canadian women in relation to the Internment. My argument is that some of the tropes that operate in the gendered construction of the subject(s) of the 
Internment are often repeated, yet rarely interrogated. In particular, I will focus upon the gendered construction of the "silent survivor of the Internment," and problematize the trope of silence reiterated consistently in the discursive production of the subject(s) of this national violence.

Published in 1981, Obasan, was the first Canadian novel about the Internment written by a Japanese Canadian author. ${ }^{38}$ Appearing the same year as Ann Sunahara's The Politics of Racism (see Chapter One), both of these ground-breaking publications launched historiographical and literary challenges to a white-dominated national discourse. Kogawa utilized the papers of Muriel Kitagawa in her characterization of one of the book's protagonists, Aunt Emily, and she acknowledges her seminal role in the novel's preface. However, it must be emphasized that Obasan is a work of fiction and it is the translation of fictional characters as emblematic of "real" and transparent selves that will be the focus of this section.

Through the novel, Kogawa is speaking back to a history theretofore barely documented. From the canonical standpoint of Canadian literature, her contribution ruptured a silence of the imaginary and in light of this fact must be regarded as a pivotal text. This moment of rupture is described by Roy Miki as an "inaugural crisis." one in which the writer expresses "the urgency to speak back to the barrier of a denied personal and communal past." 39

In the novel, the narrator, Naomi, remembers her experiences of expulsion from Vancouver, incarceration in the Slocan prison camp, and labouring on an Alberta sugar beet farm during the 1940s. After the death of her uncle, she evokes memories of her family's life prior to, during, and after these events as they gather to moum in the small Alberta town to which they were sent after their incarceration in the Slocan prison camp. It is during her engagements with the past and her conversations with surviving family members and the family minister that she comes to know the answer to a life-long question: what was her mother's fate after she left them to accompany her own mother to Japan before the war? As Naomi struggles to remember and to know, she confronts the complex ways in which memory is revelatory, both through remembering and forgetting.

What I described in my discussion of historical texts as a narrative closure in the description of the Internment history also exists in the critical response to Obasan. Roy 
Miki's examination of academics' commentaries on Obasan concludes that "all tend to incorporate a resolutionary (not revolutionary) aesthetics in their overall critical framing of the novel." $\$ 0$ Miki points out that these critics do not engage the contradictory positioning of the end document in the novel, authored by the predominantly white members of the Co-Operative Committee on Japanese Canadians (CCJC) in $1946 .{ }^{41}$ Written in "the rhetoric of dominance," the final words are those of white people who "speak for" Japanese Canadians." Miki suggests that this document contests the resolutionary frame accorded the book by its critics, but this dissonance is not engaged by those who re-present the Canadian imaginary. ${ }^{43}$ Even American critic King KokCheung's careful reading of this novel does not interrogate the contradictions inherent in the authoring and positioning of the CCJC document and she collapses this documentary artifact as part of a "political activism" that "provides the necessary condition for Naomi/Kogawa to break her personal silence."

While Cheung's comment is reflective of a lack of investigation into the historically specific political context of the Internment in Canada, ${ }^{45}$ it is also typical of the ways in which the novel is read as a narrative of closure. It is also important to note that it is through "breaking silence" that this closure is obtained. The multiple, yet similar readings of Obasan focusing upon silence in the text have lead me to problematize this trope and ask questions of the positionality of the reader/critic in relation to it. Is it really our need for closure that the anticipated speech must satisfy? Do we already know what will be said before the saying occurs? If there is no speech, what reason do we impose? What do we bring to the relationship of speech and silence?

\section{The Speech/Silence Binary}

The theme of "silence" and "speech" resonates through much of the literature regarding the removal of Japanese Canadians and Japanese Americans from the North American west coast during the 1940s. In this diverse historical, autobiographical, literary, artistic, psychological and socio-political production, this theme is foregrounded in titles such as Stone Voices, Shedding Silence, and Ton Long Silent, and much has been written about Joy Kogawa's use of silence in her novel, Obasan. ${ }^{46}$ 
The thematics of silence in Obasan are constituted through the various characters and their different relationships to the traumatic histories of the Internment, the bombing of Hiroshima, and child sexual abuse. Although Aunt Aya's (Obasan's) "silence" is highlighted in the novel - in particular her resistance to speaking about the disappearance of the narrator's (Naomi's) mother - there are many silences that circulate in this story, including that of Naomi's experience of sexual assault as a child, a violence she has not disclosed to anyone.

From my reading of the critical literature on Obasan, I would contend that the complexity of the novel has often been reduced to binary constructions of the book's protagonists and more generally the subjects of the Internment history. It might be argued that Kogawa does set up a certain binary tension between the central characters of Aunt Aya and Aunt Emily in her phrase, "How different my two aunts are. One lives in sound, the other in stone." ${ }^{47}$ But the complexities of speech and silence are elaborated upon in the following sentence, “Obasan's language remains deeply underground but Aunt Emily, BA, MA, is a word warrior." ${ }^{48}$ Clearly, Kogawa is providing a social context for speech here: Aunt Aya has a language, one that is underground, and Aunt-Emily is situated as an "educated" woman, thereby granting her some possibilities for speaking denied Aya. Perhaps most strikingly disregarded in the commentaries made about Aunt Aya and other Issei is the material fact that their first language is Japanese, forced in many ways to go "underground" both during the Internment and after the dispersal given the ways in which it was used symbolically to signify difference and disloyalty.

This inattention to the processes that produce the disappearing of the Japanese language also normalizes that loss rather than illuminating the violence of that process. What resonates in some of the literature that responds to Obasan is that within a Western modernist context, Aunt Aya gets read as the "Oriental" Issei and Aunt Emily is understood as the "Canadianized" Nisei who uses the dominant language to fight for equality. The aestheticization of Aya's "silence" and its categorization as "passivity" also obscure and reproduce the notion that within the context of the Canadian nation, people who do not speak English (or French in Quebec) are not considered to be full citizens or political subjects. What is also forefronted in analyzing Aya's silence is the equation between her "not speaking" and passivity or submission, at the neglect of analyzing 
silence in relation to the trauma induced through violence. This construction of subjects of the Internment as passive and not resisting is also part of an Orientalist construction of Japanese Canadians and a reinforcing of the white humanist subject as the active, selfactualized agent. When used in the case of women, this "passivity" also produces the image of the Orientalized object, the empty receptacle to the offerings of the "West." In addition, the description of Japanese Canadian men as passive is an Orientalist and feminizing construction used to secure the superiority of the white bourgeois heterosexual male.

United States-based scholar Shirley Geok-lin Lim makes an intrinsic connection between silence and submission when she states of Naomi's lack of knowledge about her mother: "her relatives seek to protect her through their silent submission. Her mystification...derives from her Japanese American [sic] community's silent submission to Canadian racism." ${ }^{.49}$ Lim's totalizing comment denies not only acts of resistance to racism in the novel itself but also has resonances with Ken Adachi's depiction (Chapter One) that Japanese Canadians did not protest their removal and incarceration. That the complex relations of displacement and incarceration can be reduced to such generalizations negates the negotiations variously used by those affected. I also find of interest how resistance to oppression often gets defined in accordance with the model of the humanist subject, the self-actualized speaking "rational man."

Most theoretically useful to me in understanding the deployments of the gendered "Speaking Subject" is Gayatri Spivak's posing of the question in her seminal essay, "Can the Subaltern Speak?"so While Spivak's "subaltern" is geographically located outside of the "West," I feel her analysis poses relevant issues for those of us who write about subordinated communities in a North American context. By forefronting the "object" of our investigations as the "masculine-imperialist ideological formation" 51 informing monolithic constructions of Asian women and by being self-reflexive about how these ideologies influence our constructions of our selves as academics, we will commit ourselves to situating the discussion of "speech" differently in relation to the subject(s) of the Internment. While I seek to uncover some of the "mechanics" of the constitution of "silence" in relation to the Internment and heed Spivak's recommendation that "measuring silences" 52 may help us undermine hegemonic ideological formations, it is 
not toward the "silence" of Japanese Canadians that I ultimately turn my questioning gaze. Yet as much as I do not wish to "speak for" ${ }^{33}$ the women I have interviewed, I know that this text has been produced in a situation of unequal power and privileges my speech. It is my hope that I may learn to better "speak to" 54 the ways in which privilege constructs my own silences and my opportunities to speak.

What I do not wish to engage in through my work is a revaluation of silence versus speech; rather I wish to signal the specific meanings of "speaking" and "silence" in popular constructions of Japanese Canadians. King Kok-Cheung's work on Obasan attempts to break out of the valuation of speech over silence binary. Her critique is aimed most directly at Anglo-American feminists' valorization of speech (in the "libratory" discourse of "coming to voice") and Asian Americans' refutation of silence in favour of speech. Her work also clearly emphasizes that the "mostly critical or patronizing""ss attitudes toward Asian Americans' silence rely upon Orientalist conceptualizations of the Asian subject. Cheung also draws attention, albeit minimal. to the effects of trauma on memory and the ability to articulate traumatic memories.

Nevertheless, I would argue that Cheung's emphasis on the "positive cultural and aesthetic manifestations of reticence"56 acts to reinforce difference based as it is on her aestheticization of behaviour explained by fixed notions of Japanese culture. I am not arguing against "culture" here but rather wish to signal its problematic mobilization when used as a unchanging given rather than being historically produced. As Kyo Maclear reminds us, language is mediated through relations of power, "speech and silence can be both effects of power and coercion - and means of articulation and resistance." 57 The aestheticizing of "silence" imbued with notions of Japanese cultural origins such as enryo and $\operatorname{gaman}^{58}$ reinscribes the idea of a racial/cultural fixity and does not address the shifting of cultural identification after immigration and through years of living in Canada. Also of interest to me is how these fixed cultural origins explaining "Issei behaviour" are subsequently mapped in other historical accounts and in popular discourses upon the Nisei generation in relation to their actions during and after their experiences of the Internment. ${ }^{59}$ What also seems lacking in the literature is an examination of how women are often used as exemplary of the "silent survivor," and that these very visible racialized and gendered usages of silent women variously affect the visibility of Japanese Canadian 
men. I am hence proposing we interrogate the raced and gendered use of "Japanese culture" as explanatory of "behaviour" and ask questions about how immigrant "origins" are imagined and socially produced within Canada (and the United States) and variously mobilized to secure a dominant notion of nation.

As Cheung does point out. Obasan actually disrupts the unified notion of the "silent" Issei woman through the character of Naomi's grandmother. It is she who unlocks a door of unknowing for Naomi and provides her with information about her mother's absence. Through a missive, her Issei grandmother "speaks" to her, disclosing the details of her mother's injuries and eventual death in the bombing of Hiroshima.

A Canadian critic, Frank Davey, views the phrasing in the grandmother's letter, "For the burden of these words, forgive me," as demonstrative of "an Issei text." "yasashi" in tone," "framed by apology." 60 Davey's description of "yasashi," in his view a concept embodied by Aya, is "modesty, unassuming kindness, and self-effacement." ${ }^{\circ 1}$ In this way, he draws attention to his perception of "difference" in the writing of the letter rather than focusing upon how it serves to disrupt notions of a monolithic Issei generation. This unity of not only subjectivity but also of an entire generation is necessary to Davey's formulation that the characters represent "three generations of immigrant experience." 62

That three generations living in Canada are constituted by Davey as "immigrants" reinforces the notion of their tenuous relationship to the Canadian nation. He is also quick to characterize the generations in this way: The Issei in the novel are viewed by him as "inclined towards silence and forgetting, as hoping not for full participation in their new country, but merely to be harassed as little as possible." ${ }^{\text {63 }}$ The Nisei are: "eager to participate in Canadian society, angry and indignant about their wartime treatment, and naively trusting that protest and appeals to law will bring redress." ${ }^{6+1}$ The interpretation of the Issei as not wanting "full" citizenship and the "naiveté" of the Nisei situate these generations as somehow underdeveloped, not nearing the sophistication of "real" citizens. This "infantilization" of Japanese Canadians speaks to what Kang refers to as a nationalist discourse that marginalizes racialized citizens with "the promise of achieving subjecthood and maturity in time." ${ }^{.55}$ It also fits within what Kirsten Emiko McAllister 
and Scott Toguri McFarlane describe as a "mythologized Japanese Canadian history," representing Japanese Canadians as "childlike and passive." 66

Because the two Sansei characters in Obasan are read by Davey as "dissimilar," he concludes that they cannot be read as representative of "the" Sansei generation, a generation he describes as being "vulnerable to assimilation. ${ }^{67} \mathrm{He}$ fails to engage what he views in "dissimilarity" as a potential problematic for his own homogenization of the Issei and Nisei generations. Also disturbing in his and many other accounts of generational "difference" are the ways in which these generations are always seen as separate from each other, disallowing a more complex analysis of how each generational subject position is produced discursively and historically with mutual and antagonistic overlappings, disallowing the blurred boundaries and fissures in our relationships to each other and to nation.

I do, however, wish to acknowledge the important self-identifying processes of the generations. I see these generational identifiers as signifiers of social relationship and relationship to nation. They can be used to situate self in relation to immigration and the Internment, and hence are linguistic mappings of the situatedness of witnessing historical trauma. ${ }^{68}$ What I am trying to break out of is this codifying of behaviour accorded to each generation, the fixing of subjectivity through a categorical generational ascription. As has been revealed, this use of "Issei," "Nisei," "Sansei" can also further a totalizing racialized and gendered discourse that cannot convey the complexity of social arrangements experienced by Japanese Canadians in relation to the monumental shifts of the Internment and geographical dispersal. What I want to admit into my work are the intersections amongst and between generations of women and how material and social conditions construct our relationality and our re-memberings of the Internment. I would in fact argue that Kogawa's mapping of the generations in her book are less clear than what critics impute them to be; for example, Naomi's uncle, although born in Japan, straddles the generations of Issei and Nisei, since he was brought to Canada as a child. Yet he is consistently referred to as Issei. Davey's and other readings of Obasan, however, clearly illustrate how a pre-given notion of the subject(s) of the Internment operates in the reader's approach to the novel. 


\section{The Speaking Subject of the Internment}

When the racialized woman is called into view by the white subject, it is important to note this viewing is always in relation to the racialized man. A particular claim in the Internment literature, as analyzed in Chapter One, is that it shifted gender relations between women and men. When attempts are made to construct the "Japanese" woman as "progressing" toward the model of the white liberal subject, the "Japanese" man must thereby be shown as "more patriarchal" than the white Canadian male.

Frank Davey notes in his essay on Obasan that the "speaking" characters in the novel "break with the Japanese woman's confinement to silence or unprovocative discourse." ${ }^{\circ 9}$ The speaking woman therefore is portrayed as breaking her connections to her Japanese "confinement," aspiring toward the model of the white liberal subject. By concluding that Obasan is thus a "feminist novel," Davey invokes a particular white Western-informed notion of feminism where the man can only be seen in oppositional terms. This conclusion is interwoven through an Orientalist and heterosexist discourse, casting aspersion upon Japanese Canadian men in his comment that Naomi and Emily are "single because of an apparent lack of worthy men."70 While Davey does not specify Japanese Canadian men as the "unworthy" ones, his prefatory remarks about Japanese patriarchy and the breaking away from this repression by the novel's two "speaking" characters would lead one to conclude that Davey is referring to men who share this cultural history. In addition, interestingly, Davey does not mention that it was actually a white man whom Naomi had dated and with whom she had felt the mark of "difference."

As earlier stated, Kogawa made use of the papers of Muriel Kitagawa in her composition of the character of Aunt Emily in Obasan. These papers were later edited and

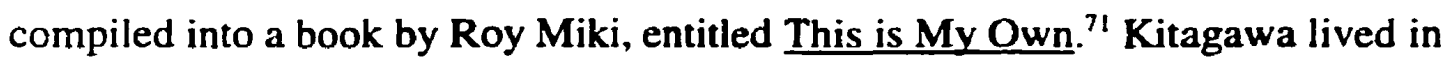
Vancouver with her husband and two children at the outbreak of World War II. She was a journalist, pregnant with twins when she was one of few people granted the authorization to move with her family to Toronto in 1942 . Her papers include letters she wrote to her brother, Wesley Fujiwara, who was a medical student at the University of Toronto. These letters document her perceptions of the expulsion, incarceration, and dispossession of her friends and family. While these documents and the newspaper articles published in This is My Own and extant in her manuscript bequest to the National Archives of Canada are 
deserving of a more thorough study than is possible here, I would draw attention to the fact that her writings are a complex representation of her relationship to nation and Canadian citizenship.

I mention Kitagawa briefly here to illustrate how her letters and journalistic accounts, rare textual archives written in the 1940s, are mobilized to construct the gendered speaking "Canadianized" subject of the Internment. I would argue that she is much lesser known than the fictionalized character of Aunt Emily in Obasan, who is based on her. Through Obasan and its resounding impact, in many ways, Aunt Emily has taken on a metonymic presence larger than the "real" woman on whom she is based." Yet Kitagawa has also become a critical figure in how the Internment gets re-narrated at moments of national engagement with this history and her important re-appearances in these moments illustrate how visibility is also always marked by discourses of nation.

On the occasion of the signing of the redress agreement with the Canadian government, Gerry Weiner, then Minister of State for Multiculturalism, issued a press release in which he quotes from Obasan in answering his rhetorical question: "Why did [Japanese Canadians] remain loyal to this country?" He quotes Aunt Emily: "Is this my own, my native land?... Yes. It is. For better or worse, I am Canadian." ${ }^{73}$ Although Weiner attributes the words to Kogawa's protagonist, those familiar with Kitagawa's writings will identify this section as from her essay, "This Is My Own." Aunt Emily/Kitagawa's words as the authentic screen - "Only someone who is Japanese Canadian can explain" - for his subsequent recuperation of the Canadian nation. He reasserts through a liberal discourse of progress how Canadians have "grown" and "acquired new wisdom and compassion" in the years after the Internment. ${ }^{\text {is }}$

In a more recent example of the use of Kitagawa's work, I turn to The Toronto

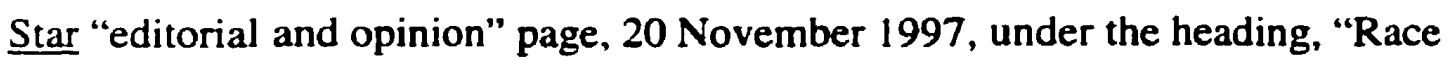
Relations." A week after the Canadian Race Relations Foundation office was finally opened in Toronto, the Star used approximately a third of a page to announce the establishment of the Foundation, "part of the 1988 redress settlement."76 According to the Star, "the most moving part" of the Foundation's inauguration was a reading from This is My Own (although note that the Star miscites the book as Letters to Wes). The Star announces the Foundation's opening by re-narrating in a few sentences the Internment 
story; but most of the text is quoted from Kitagawa's work. This includes Kitagawa's devastating descriptions of Hastings Park and the reaction of her children and friends to the "Nazi-fashion[ed]" "hell" of B.C." Kitagawa's words, both here, and in the original texts are complex, critical, and revelatory of the struggle to define self and citizenship in the face of a violence that daily demeans the self and questions one's entitlement to citizenship. Interestingly, the last quote from Kitagawa used by the Star are her reconstituted words similarly used earlier by Weiner to portray Kitagawa as loyal to nation, "This is my own, my native land!" "God! God! were my soul 'so dead' I could not thus agonize for the land betrayed!" 78

Kitagawa, thus presented, evokes the image of the loyal citizen who despite the Internment remains committed to Canada. Her's is an unmistakeably gendered discourse, where devotion to children, husband, and family are used in the service of narrating a "gentler," "more compassionate," feminized image of nation. In a review of This Is My Own, Gordon Hirabayashi recommends that it be given to "new Canadians" with their "citizenship certificate." her character, its weakness when citizens waver, its strength when citizens give commitment to the principles for which she stands." 80 This comment from Hirabayashi has an even more complex significance, when we consider that he challenged the United States government in May 1942 by refusing to honour curfew orders and the orders to move from the coast. Hirabayashi pursued this challenge to the U.S. Supreme Court where the charges of violating the curfew order and failing to report for expulsion were upheld. ${ }^{81}$ Hirabayashi's statement, written in 1942, explaining why he refused the orders resonates with what he describes of Kitagawa's struggle and its relationship to nation: "I consider it my duty to maintain the democratic standards for which this nation lives." 82

Some might argue that these appearances of Kitagawa in state discourses describing the Internment are evidence of remembering the atrocity of national violence. I would like to suggest that the ways in which Kitagawa is used to narrate this history in these governmental acknowledgments is evidence of the forgetting of the extent of the violence and how it was multiply contested. They also serve to commodify a particular Japanese Canadian subjectivity reifying nation and the liberal subject as its citizen. Represented as a "loyal, assimilated citizen," Kitagawa's scathing criticism of the actions 
taken by the government and Canadian citizens in the 1940s may be overshadowed. Her "resistance" in naming these atrocities is used in a way that attests to the inherent goodness of the always ever redeemable Canadian nation. In the unique attention given to her as a loyal critic, she is regarded as unique and autonomous from the community for whom she is designated spokesperson. In this way, Kitagawa is re-constituted in the model of the liberal subject who is allowed to speak freely in Canada and who uniquely "resisted" injustice while her community largely "chose" to remain "silent." What gets forgotten in these re-presentations and uses of Kitagawa are her profound analyses of violence against Japanese Canadians and also how her "speech" was constituted through her hierarchically-situated subject position as a writer who, though expelled from Vancouver, was moved to Toronto, a space different than that occupied by most incarcerated Japanese Canadians. Hence what is reproduced through these images is the mythology that most Japanese Canadians did not contest nor resist their incarcerations. This representation insidiously constructs non-resistance as evidence of a non-violent nation, furthering the forgetting of how the Internment was inherently violent and critical to nation-building.

The mobilization of gender is also extremely interesting here as Kitagawa is clearly a feminized symbol of loyalty. While Japanese Canadian men who served for Canada during World War I and World War II are sometimes used to conjure up similar images of loyal citizens (an approbative militaristic symbolism from which women are excluded), they appear less in public discourses of Internment than their counterparts in the United States. What must by interrogated are not only representations of Kitagawa by the state, but instances where Japanese Canadians similarly reify nation and the liberal subject through our work and commemorative practices. Following Yeğenoğlu's argument that "the question of representation is at the same time a question of constitution," ${ }^{83}$ we must ask ourselves how we are implicated in dominant discourses consolidating "difference."

I end with this brief analysis of Kitagawa to illustrate how the tropes of silence and speech in the construction of the Internment narrative are also always deeply associated with narrations of nation. Throughout this thesis, I will draw attention to these tropes and argue that the reiteration or "citation" of the image of the "silent" Japanese 
Canadian is also about relations of power. I will thus continue to interrogate the "factual status" of this image, its "naturalness" and how the processes of citational normalization conceal "the conventions upon which it is based."

It is clear that both the tropes of silence and speech make use of highly visibilized constructions of Japanese Canadian women: the mapping of their silence and speech as mutually exclusive categories is integral to the ways in which the Internment history is reconstituted. Silence is indicative of difference; speech is the mark of aspiring to the sameness of the white bourgeois subject, part of the gift of "freedom" gained through nation. The overdetermined placing of Japanese Canadian women in the Internment narrative underlines that nation is an always en-gendered and racialized space.

\section{The Speaking Subjects: Children of Survivors}

Kogawa's work illustrates the complex positioning of an author in relation to an Internment text and how this complexity, this constructedness of the Internment subject(s) may not be grasped by the reader. For example. Kogawa, herself a Nisei survivor, chooses the narrator of the book, Naomi, to be a Sansei. In a more recent acclaimed novel, Kerri Sakamoto who is a Sansei, born in the 1950s, chooses a Nisei narrator for The Electrical Field ${ }^{85}$ These decisions to narrate novels from subject positions generationally different from that of the author are interesting though rarely commented upon aspects of these novels. As was earlier stated, the designation of fictional characters as emblematic of their generations is a problematic construction of Japanese Canadians as a knowable group. Nevertheless, I am not arguing that only members of each generation can accurately portray their generation; rather, I am challenging the notion of any representation being able to reveal "the" authentic subject.

I would argue that the Issei have been the most written about by others not of their generation (very few texts in English have been generated by them), and the images rendered of them are the least complex, thus leading to the monolithic constructions earlier discussed. What I would like to signal here is that it is the children of survivors, including the Nisei, who through the need to bear witness to their history are creating images of Japanese Canadians in relation to the Internment and that these images are constructed ones. 
A psychological study that looks at the effects of the Internment on children of Japanese American survivors concludes that "the vast majority of Sansei feel that the incarceration has affected their lives in significant ways. ${ }^{86}$ Donna Nagata's findings were based on a survey of over seven hundred Sansei, including forty in-depth interviews. While a study investigating the effects of the incarceration on survivors' children has not been conducted in Canada, literary and artistic work by Sansei and Yonsei artists testify to their interpretations of this history's effects and their need to bear witness to this legacy. Filmic examples of these testimonies include Michael Fukushima's animated exploration of his father's deportation from Canada, Minoru: memory of exile, and Midi Onodera's examination of her relationship to her grandmother in Displaced View. $A$ notable American film, History and Memory: For Akiko and Takashige, explores Rea Tajiri's relationship to her mother's incarceration at the Poston concentration camp through images of her own visit to the camp site. ${ }^{88}$ These images are juxtaposed with American film footage of World War II and white actors portraying Asians in Hollywood films, thus posing questions of representation and historical memory. Another powerful Canadian example is Haruko Okano's monograph, entitled Come Spring: Journey of a Sansei. Through poetry, prose, and visual art, Okano describes her "deep longing for a sense of physical and emotional history." 89 All of us who are engaged in the production of images of Japanese Canadians are participating in the construction of the Japanese Canadian subject and most decidedly (though not always admittedly) our image of others is necessarily tied to the image we wish to present of our selves.

In most of the literature, the Sansei generation is presented as the "speaking" subject in relation to the previous generations' "silence" regarding the Internment. One essay that examines memory and Sansei's reconstruction of the Internment through poetry in the United States is written by Stan Yogi.

In this essay, Yogi reconstructs the "Sansei" as an undifferentiated category. He uses poet Janice Mirikitani's work to make a case for the Sansei as the speaking subject when he states that "the daughter has taken on the role of parent because she has the strength to confront the past that the mother cannot acknowledge." 90 This infantilization of the Nisei subject is produced within a context, as previously mentioned, where Asian North Americans are readily seen as less developed and deserving of the rights of nation. 
No acknowledgment of the social conditions informing the Sansei's ability to speak that are different than for the Nisei are raised in this essay.

Yogi also subscribes to the notion of "speech" as healing. His statement, "Speaking frees memory, even tragic memory, and transforms pain and denial into strength and power"9l presents a simplistic notion of memory and power, conferring on the act of speaking a transformative resolution to the legacy of Internment.

Yogi continues his thesis that Sansei have an "incomplete sense of themselves" due to the "absence of personal narratives and family stories about the war years." line of argument replicates a prominent discourse in the construction of children of survivors, in particular, the descriptions of the Sansei and their "lack" (of selfhood, of history, etc.) being directly attributable to their parents' "silence" regarding the Internment. In response to this discourse, I would argue that the selfhood that we have been trained to yearn after is that of the liberal subject for whom completeness is possible, tied as it is to privilege and domination. It is this continual singularization of the "silence" as the "origin" of destabilization that obscures the more complex configurations of oppression and trauma. I would propose we examine the yearning after the "comolete" sense of subjecthood and creatively situate these "incomplete" selves as the site of contestation rather than reify the "speaking" subject as always ever the ideal of resistance.

What I am raising in this discussion of the position of children of survivors in relation to the Internment is my concern for the ways in which we configure the images of those who were incarcerated. I would encourage us to look at the assumptions behind these images: What are the images we hold of ourselves, as gendered, racialized, sexualized, classed subjects? And how do we position our selves within the nation state? Does what we interpret as their silence become "the occasion for our speech"?"3

\section{An Illustrative Example}

An e-mail message from a discussion group prompts me to read for the first time a copy of Sports Dlustrated. The message: "Read the article in the January 1998 issue of the magazine on National Hockey League (NHL) player Paul Kariya. It's bringing the Internment story to a whole new audience." "Yes," I think to myself, "But what story?" 
I open the magazine and am struck immediately by the one-and-a-half page photo images: a close-up of Paul Kariya's face on the left, the end of a hockey stick just visible below his chin, and connected to Kariya's photo on the right is his grandparents' wedding photo from 1937. The Kariyas are dressed in formal Japanese attire; his grandmother is seated, his grandfather standing beside her. Across the photos lies the title of the article, "Different Worlds," and the sub-heading is displayed only over Kariya's portrait: "Superstar Paul Kariya is proud of his heritage but also proud to be an Olympian for Canada, the country that punished his grandparents for being Japanese."

That the reiteration of the Internment story is about nation is clear from its continual reformulation in popular media when Japanese Canadians or "CanadianJapanese" (as Kariya is referred to) gain notoriety and are called upon to autobiographize for a generalized (predominantly white) audience. On the occasion of the Winter Olympics in Nagano, Japan, Sports Illustrated has decided to feature one of the Canadian team's star players and recount his relationship to the games and to the host country, Japan. ${ }^{95}$ While I will not present an in-depth textual analysis of this particular article, I use it to demonstrate how certain tropes are consistently used in writing the Internment story. In particular the tropes of silence and shikata ga nai (see Chapter One) are of interest to me here, and the dichotomization of Kariya (read Canada) and his grandparents and, in particular, his grandmother (read Japan) as from "different worlds."

While some might argue that women have been forgotten in some historical accounts of the Internment story, I propose that this forgetting is much more contradictory and complex than that suggested by the notion of superficial absence. What is in fact of interest to me is the use of women through their strategically situated absences and presences in the reconstruction of the Internment history and the subsequent lack of analysis of this gendered selectivity and representation.

Witness the Kariya story. It begins and ends with references to his grandmother, Fumiko. Typically, it is the woman to whom the "shikata ga nai" attitude is assigned, the resignation and passivity of the "Other," an Other who is both raced and gendered. Strikingly, the article ends with a quote attributed to her, describing "her time in the internment camp" as "It can't be helped." $\%$ Of note also is the fact that the Japanese translation of this term is not used but it clearly conveys, even in English, its racializing 
effect, to other the grandmother in contrast to the "Canadian" grandson. What is also missing in this construction is acknowledgment of the fact that this "Japanese" grandmother may have actually been born in Canada or in the least has lived most of her life in this country. This is deduced from the information that Kariya is "fourth generation."

It is also a woman who is used to be the testifier to the Internment history through the use of her re-memberings of, once again, grandmother Fumiko. Kariya's eldest sister. Michiko, the "only member of the family he would allow SI to interview for this story, "47 serves to address the trope of silence. Her testimony follows and I would emphasize both reinforces and contradicts Kariya's statement, "It never was brought up at home."98 Michiko states both that Fumiko "never went into details about what it was like in the camp," and that "Certainly we knew about the camps. We knew our father had been born there. But there was no bitterness on my grandparents' part." 99

What does the reader of this article take away from it? Are the meanings embedded within these fragments of re-membering grasped as complex? For example, do we notice their contradictory memories: Kariya states categorically "it" was never brought up at home while his eldest sister maintains they "certainly" knew about the camps. How are these re-memberings gendered, both in their reconstructive notions of what is attended to and whose memories are valued? Is it noted that the grandmother is always spoken about and never the speaking subject? And how does the gender and age of the witness affect what is known and knowable about the Internment? Is it possible that some members of the family are called upon to witness the testifier's history in ways that others are not?

What are the details missing that Michiko seeks to know and is this missing knowledge related to her construction of her grandparents as "not bitter, never accusatory"? How do testifiers, recorders, and readers of these testimonies re-create themselves in their telling/reading of this history? And what is the investment in not knowing the Internment history or knowing it a very particularized way?

I would suggest that although a complicated reading is possible from these fragments of testimony reconstructing the grandchildren's relationship to the Internment, its purpose is to reiterate the trope of silence so consistently mapped upon survivors of 
this historical violence. This trope, gendered and raced in its utterance, sets up the author's redemptive conclusion that the sum total of the Internment experience for the grandmother was "It can't be helped." 100

The author of the article acts as "historian," reproducing the description of the Internment history without any referencing to secondary sources, I might add. This reproduction contains a fair bit of detail given the context of its telling. Its expository nature implicitly suggests the author's use of other historical sources and indicates the critical place of these references in the continuing narration of popular media renditions.

Yet the harsh "facts" of the author's retelling are softened by the liberal discourse framing their enunciation. Once again the Internment is portrayed as a moment, a "shameful chapter" in the linear narrative of Canadian history. ${ }^{101}$ And the author uses Kariya's testimony, uttered at a Calgary steak house, "The past is history,"102 to put the Internment in its place of resolution.

Kariya must also be portrayed as the liberal seif-made autonomous man, the epitomic subject of sports narratives, an icon for the national sport of Canada. This is done through portraying Kariya as rejecting the otherness embodied by his grandmother, her attachments to the Japanese Canadian community and to the Internment history itself, as foreign to him and temporally distant. As his sister says, "To associate with a group of people based only on heritage is a strange concept for Paul and me." ${ }^{103}$ Kariya reinforces his rejection of this community by proclaiming his disdain for "labels." In this way, he also distances himself from the necessary critique of domination and Canadian nation that always underlies the Internment story as a possibility. And it is this possibility that must be contained through narratives such as this.

Hence, Kariya is re-made as an independent rational subject, encouraged by his parents to "find out who you are," rather than being constrained by "labels." He fulfils the Canadian dream of making it, despite his family's past. His participation in sports is linked to his father's playing rugby for Canada in the 1960s. Thus Kariya and his father are constituted as citizens of nation; sports iconography both allows and necessitates this construction of the liberal self-actualized man, patriotic to nationhood, especially if they are valued athletes of colour. This gendered masculine construction of athlete as loyal citizen and as man of colour also necessitates the shadow image of the other, the naming 
of what he is not or what he is trying hard not to be. And in this case, the "foreigner" is in his midst and family, in the figure of the gendered feminized racialized construction of his grandmother, Fumiko.

Of course, as Lisa Lowe has pointed out, this relationship to nation is an ambivalent one for Asian men living in North America. This ambivalence is most obvious at the end of the article where Kariya admits that his dad taught him to be humble. "Maybe this is going against the norm, but humility is what we learned." 104 In this phrase, there is the suggestion that in fact, Kariya may be more like his grandmother than he has been presented as being. Humility is understood by Kariya as being against the norm, what I would call the national norm of white masculinity. Kariya's inheritance of humility is a racialized one, but at the same time it is masculinized because it comes from the athlete father. While expressing his desire to reject "labels," Kariya is also astute in his public rebuttal to being asked about his Japanese origins, in challenging that he is never asked about his Scottish ones through his mother. This handing down of humility is both gendered and raced, just as is his white mother of Scottish origin's absence from the narrative. And it is clear from this passage that Kariya's relationship to nation may be a tenuous one and construction of his difference could be mobilized differently in other contexts or if he falls from the nation's grace.

Ultimately, what I wish to re-emphasize in my reading of the Sports Illustrated article is how the construction of Kariya's masculinity in the iconography desired by the magazine depends upon the highly visible presence of woman as racialized other. And to even discuss the Internment in this context celebrating masculinized nationalisms necessitates a distantiation of the Internment history and the effects of that history on the part of Kariya. Re-citing images of silent Japanese Canadians stating "It can't be helped" becomes the resounding and familiar refrain in a collective national Internment narrative.

\section{Conclusion}

In this chapter, I have argued for understanding systems of domination as interlocking in the construction of the subjects of the Internment. The trope of "silence", used in interpretations of the novel, Obasan, is an example of how systems of domination are used to keep in place the hegemony of the white male subject by constructing him in 
relation to the racialized Japanese Canadian woman. The binary of the Japanese woman and the Japanese "Canadianized" woman are critical in constructing the concomitant notions of Japan as a backward and patriarchal nation in contrast to the progressive nation of Canada. The patriarchal Japanese (Canadian) man is thus used to produce the progressive white Western man whose very masculinity also depends upon an invisibilizing and I would argue feminizing of the former. In progressing toward the ideal of the white liberal subject, Japanese Canadian women, like Aunt Emily and Muriel Kitagawa, are allowed a circumscribed space from which to speak. When used by representatives of the state, their descriptions of the violence must be contained, and redemptive closure must be the overriding narrative echoing in the nation space.

Children of survivors are also the memory bearers of this history. The Sports Illustrated article on Paul Kariya is just one example that utilizes the enfiguration of women to repeat the silence trope. In Chapters Eight and Nine, I will examine more closely how children come to know of their families' histories of Internment. In our need to articulate this history, as its inheritors, we must be aware of the constructedness of our representations. Who are the subjects of these representations and how does our struggle with the legacy of this history inform the ways in which we remember and bear witness?

In Chapters Three to Nine, I will seek to illustrate how some women respond to the forgetting produced within the Canadian nation. Their narratives evaluate the effects of national violence on their lives and offer multifarious challenges to how the subject, citizenship, and nation have been conceptualized through a unitary liberal discourse of Canadian nationhood.

\section{Endnotes: Chapter Two}

1. Kang, "Compositional Subjects," p.4.

2. Inderpal Grewal, "Autobiographic Subjects and Diasporic Locations: Meatless Days and Borderlands," in Scattered Hegemonies, edited by Inderpal Grewal and Caren Kaplan (Minneapolis and London: University of Minnesota Press), p.233.

3. Michel Foucault, Power/Knowledge: Selected Interviews and Other Writings, $1972-$ 1977 (New York: Pantheon, 1980), p.97.

4. Ibid., p. 119. 


\section{Ibid.}

6. Julian Henriques, et al., "Introduction to Section Two. Constructing the Subject," in Changing the Subject: Psychology. Social Regulation and Subjectivity, by Henriques, et al., (London and New York: Methuen, 1984), p.117.

7. Michel Foucault, The History of Sexuality, vol.1, translated by Robert Hurley (New York: Random House, Vintage Books, 1990), p.95.

8. Meyda Yeğenoğlu, Colonial Fantasies (Cambridge: Cambridge University Press, 1998), p.21. I would like to thank Sheila Batacharya for informing me of Yeğenoğlu's work.

9. Goldberg, Racist Culture, p.57. See also Henriques, et al.. "Introduction to Section Two," p.97, for a discussion of Althusser's notion of interpellation.

10. Scott, "Experience," p.34.

11. Yeğenoğlu, Colonial Fantasies, p.8.

12. Foucault, Power/Knowledge, p.83.

13. Gayatri Chakravorty Spivak, "Can the Subaltern Speak?" in Marxism and the Interpretation of Culture, edited by Cary Nelson and Lawrence Grossberg (Urbana and Chicago: University of Illinois Press, 1988), p.294.

14. Patricia Hill Collins, Black Feminist Thought: Knowledge, Consciousness, and the Politics of Empowerment (New York and London: Routledge, 1991), p.18.

15. Ibid., xiv.

16. Some of the many thinkers who have helped me understand how systems of domination interlock in subject formation are Chrystos, see for example, Dream On (Vancouver: Press Gang, 1991); Audre Lorde, for example, Sister Outsider (New York: The Crossing Press, 1984); Lisa Lowe, see for example, Immigrant Acts, and Sherene Razack, see for example, Looking White People in The Eye.

17. Collins, Black Feminist Thought, p.16.

18. Goldberg, Racist Culture, p.5.

19. Razack, Canadian Feminism and the Law, p.16.

20. Henriques, et al., "Introduction to Section Three. Theorizing Subjectivity," in Changing the Subject, by Henriques, et al., p.203.

21. Razack, Canadian Feminism and the Law, p. 15; and Yeğenoğlu, Colonial Fantasies, pp.5-6. 
22. For an analysis of this binary construction, see for example, Chandra Talpade

Mohanty, "Under Western Eyes: Feminist Scholarship and Colonial Discourses," in Third World Women and the Politics of Feminism, edited by Chandra Talpade Mohanty, Ann Russo, and Lourdes Torres (Bloomington and Indianapolis: Indiana University Press, 1991), pp.51-80,

23. Goldberg, Racist Culture, p.4. See also Homi Bhabha's analysis of the western gaze as constructing the image of the "Other" in "The Other Question..." Screen 24, 6

(November-December 1983): 18-36.

24. Kang, “Compositional Subjects,” p.175.

25. Grewal, “Autobiographic Subjects," p.251.

26. Rey Chow, Writing Diaspora (Bloomington and Indianapolis: Indiana University Press, 1993), p.45.

27. Lowe, Immigrant Acts, endnote 10, p.220.

28. Kang, "Compositional Subjects," p.134.

29. Joy Kogawa, Obasan (Toronto: Lester \& Orpen Dennys, 1981 ; Toronto: Penguin, 1983).

30. Kang, "Compositional Subjects," p.85.

31. I use Roger Simon's notion of commemoration here: "a practice which enables a living memory, one that dialectically presses on the sense of one's future purposes and possibilities." Simon, "The Pedagogy of Commemoration and Formation of Collective Memories." Educational Foundations 8, 1 (Winter 1994): 10.

32. For an analysis of the construction of "innocence" and subjectivity, see Mary Louise Fellows and Sherene Razack, "The Race to Innocence: Confronting Hierarchical Relations Among Women," The Journal of Gender, Race and Justice 1, 2 (Spring 1998): 335-352.

33. For a discussion of "just recollection" or "just remembrance" see Roger Simon "The Pedagogy of Commemoration," p.7 and Kyo Maclear, "Beclouded Visions: HiroshimaNagasaki and the Art of Witness," (master's thesis, University of Toronto, 1996), p.19.

34. Edward Said, Orientalism (New York: Random House, Pantheon Books, 1978; New York: Random House, Vintage Books, 1979).

35. Lisa Lowe, Critical Terrains (Ithaca and London: Cornell University Press, 1996), ix-x. I am aware of Meyda Yeğenoğlu's criticism of "pluralizing" colonialism (or Orientalism) as achieving another form of binarism, between the "homogeneity" and "specificity" of colonial discourse. Yeğenoğlu, Colonial Fantasies, pp. 36-38. I adopt Lowe's insistence upon the historicizing of Orientalism in order to contest the notion of 
homogeneous racialized subjects and the processes of subjection by colonialism that Yegenoğlu's work so brilliantly analyzes, and to draw attention to the ways in which Japanese Canadians, at times, are non-differentially constructed in relation to Japanese Americans.

\section{Lowe, Critical Terrains, $x$.}

37. Some examples of critical writings on Obasan include, King Kok-Cheung, Articulate Silences: Hisave Yamamoto, Maxine Hong Kingston, Joy Kogawa (Ithaca and London: Cornell University Press, 1996); Scott McFarlane, "Covering Obasan and the Narrative of Internment," in Privileging Positions: The Sites of Asian American Studies, edited by Gary Y. Okihiro, et al. (Pullman, WA: Washington State Press, 1995), pp.401-411; and Roy Miki, "Asiancy: Making Space for Asian Canadian Writing," in Privileging Positions, pp.135-151.

38. Although Shizuye Takashima's book, A Child in Prison Camp (Montreal: Tundra, 1971) was published before Obasan, Takashima's account was recognized in the genre of autobiographical writing and therefore as non-fiction. It was also identified as a book for children and received numerous awards, including the 'Choice Book' medal of the Toronto Children's Book Centre. Despite the critical interpretations of Obasan as autobiographical, it is deemed a novel by its author and has been marketed as such.

39. Miki, "Asiancy," p.142.

40. Ibid., p.143.

41. According to Ann Gomer Sunahara, the Toronto-based Cooperative Committee on Japanese Canadians (CCJC) "evolved from a Young Women's Christian Association set up in 1943 to assist with the resettlement of single Japanese Canadian women." Sunahara, The Politics of Racism, p.131. The CCJC later organized to fight the government's plans to deport Japanese Canadians. See also, Peter Nunoda, "A Community in Transition and Conflict: The Japanese Canadians, 1935-1951" (Ph.D. dissertation, University of Manitoba, 1991) for a description and analysis of the work of the CCJC.

42. Miki, “Asiancy," p.144.

43. See also Lisa Lowe's conclusion that Obasan presents "irresolution of Japanese Canadian subjects." Lowe, Immigrants Acts, p.51.

44. Cheung, Articulate Silences, p. 153.

45. That Obasan has been claimed by some scholars as a contribution to the relatively newly-initiated canon of Asian American literature is an interesting development. This inclusion will, it is hoped, lead to more engagement of works produced by Asian Canadians and build toward a transnational culture of resistance. However. I would also caution that absorption of our work as non-differentiated, that is "like" the "American" experience, reflects a non-interrogation of the historically specific construction and 
production of the Canadian nation. See, for example, Cheung's statement: "Asians in the United States and Canada have had parallel experiences.... After the bombing of Pearl Harbor, for instance, people of Japanese ancestry living along the Pacific coasts of both countries were forcibly removed from their homes; those who were U.S. and Canadian citizens were denied their constitutional rights." Cheung, Articulate Silences, xv. Also note that Canada did not have a constitution in 1941 .

46. Keibo Oiwa, Stone Voices: Wartime Writings of Japanese Canadian Issei (Montreal: Vehicule Press, 1991); Janice Mirikitani, Shedding Silence (Berkeley: Celestial Arts, 1987); Roger W.Axford, Too Long Silent: Japanese Americans Speak Out (Lincoln, Nebraska: Media Publishing and Marketing Inc., 1986). For an analysis of silence in Obasan, see Cheung, Articulate Silences. By citing these sources, I am not indicating that these authors view silence in the same way. Rather, it is my intent to illustrate the predominance of this theme or its metaphorical usage in the titles of Japanese Canadian/American-specific writings.

47. Kogawa, Obasan, p.32.

48. Ibid.

49. Shirley Geok-Lin Lim, 'Japanese American Women's Life Stories: Maternality in Monica Sone's Nisei Daughter and Joy Kogawa's Obasan, Feminist Studies 16, 2 (Summer 1990): 291.

50. Spivak, "Can the Subaltern Speak?" See also Norma Alarcón and Rey Chow's analyses of the "speaking subject." Alarcón, "The Theoretical Subject(s) of This Bridge Called My Back and Anglo-American Feminism," in Making Face, Making Soul:

Creative and Critical Perspectives by Women of Color, edited by Gloria Anzaldúa (San Francisco: Aunt Lute Foundation, 1990), pp.356-369; and Rey Chow. Writing Diaspora.

51. Spivak, "Can the Subaltern Speak?” p.296.

52. Ibid., p.296, emphasis in the original.

53. Ibid., p.295.

54. Ibid.

55. Cheung, Articulate Silences, p.2.

56. Ibid., p.8.

57. Kyo Maclear, "Not in So Many Words: Translating Silence Across 'Difference,"” Fireweed 44/45 (Summer 1994): 7-8.

58. I have chosen not to reproduce the translations of these "cultural" concepts as it is the fact that this translation occurs unreflexively, reproducing a position of western authority in relation to Japanese Canadians that I am trying to draw attention to here. 
59. See, for example, Ken Adachi's statement: "Enryo...gaman... and, perhaps most significantly, the shikata-ga-nai syndrome (it can't be helped), along with an innate respect for authority, helped to shape their acquiescence to evacuation and enabled them to overcome, at least outwardly, the traumatic events and to carry on with the task of resettlement." Adachi, The Enemy That Never Was, pp.355-356.

60. Frank Davey, "The Land That is Like Every Land," in Post-National Arguments, by Frank Davey (Toronto: University of Toronto Press, 1993), p.i04.

61. Ibid., p.104.

62. Ibid., p.103.

63. Ibid.

64. Ibid.

65. Kang, "Compositional Subjects," p.217.

66. Kirsten McAllister and Scott McFarlane, "Documentary Perpetuates Myth of the Passive Japanese Canadian." The Bulletin 34, 12 (December 1992): 25.

67. Davey, “The Land," p.103.

68. See Pierre Nora, "Between Memory and History: Les Lieıx de Mémoire," Representations 26 (Spring 1989), p.19, for an analysis of the relationship of "historical generation" to the construction of memory.

69. Davey, "The Land," p.104.

70. Ibid., p.105.

71. Kitagawa, This Is My Own.

72. I would like to thank Roy Miki for discussing this point with me.

73. Miki and Kobayashi, Justice in Our Time, p.150.

74. Kitagawa, "This is My Own, My Native Land!" in This is My Own, p.288.

75. Miki and Kobayashi, Justice in Our Time, p.151.

76. Editorial: “"We are the Israelites on the move," Toronto Star, (20 November 1997), p.A28. Although the agreement to establish a "Race Relations Foundation" was part of the 1988 negotiated settlement with the federal government, it was not until October 1996 that the Foundation was proclaimed into law. See Miki and Kobayashi, Justice in Our Time, pp. 138-139, for a description of the terms of the redress agreement; and Art Miki, Nikkei Voice 13, 3 (April 1999), pp. 1, 11, for a description of the Canadian Race Relations Foundation and its activities. 
77. Toronto Star, "We are the Israelites," p.A28.

78. Ibid.

79. Gordon Hirabayashi, review of This Is My Own, by Muriel Kitagawa, in Canadian Ethnic Studies 21, 3 (1989), p. 140.

80. Ibid., emphasis added.

81. Sucheng Chan, Asian Americans: An Interpretive History (Boston: Twayne Publishers, 1991), p.136. Hirabayashi was one of three men (Fred Korematsu, Minoru Yasui, and Hirabayashi) who challenged the constitutionality of the curfew and expulsion orders to the U.S. Supreme Court. Mitsuye Endo legally challenged the War Relocation Authority's "right to keep her under custody." Years after incarceration, the Supreme Court ruled that Endo be released "unconditionally." The charges against the men were upheld. Chan, Asian Americans, pp.135-138. For an analysis of these cases, see Peter Irons, Justice at War: The Story of the Japanese American Internment Cases (New York and Oxford: Oxford University Press, 1983). In the 1980s. a campaign was organized to reverse the decisions in the cases of the three men. On 10 February 1986, Judge Voorhees vacated Hirabayashi's conviction for failing to report but did not overturn the curfew conviction. Upon appeal, the charge of violating curfew was set aside. See Peter Irons, ed., Justice Delayed: The Record of the Japanese American Internment Cases (Middleton, CT: Wesleyan University Press, 1989) for a description of the appeals of these convictions. For an interpretation of the Hirabayashi case by a child of survivors, see David Mura, Where the Body Meets Memory (New York: Doubleday, 1996).

82. Gordon Hirabayashi quoted in Kandice Chuh, "Transnationalism and Its Pasts," Public Culture 9 (1996): 101. Chuh presents an interesting examination of Hirabayashi's case and its significance for nation and transnationalism.

83. Yeğenoğlu, Colonial Fantasies, p.53.

84. Ibid., p.38.

85. Kerri Sakamoto, The Electrical Field (Toronto: Alfred A. Knopf, 1998).

86. Donna Nagata, Legacy of Injustice (New York and London: Plenum Press, 1993), ix.

87. Michael Fukushima (Director), Minoru: memory of exile (Canada: National Film Board of Canada, 1994); Midi Onodera (Director), Displaced View (Canada: McCano Film Artists Inc., 1988).

88. Rea Tajiri (Director), History and Memory: For Akiko and Takashige (United States: Rea Tajiri, 1991). For a critique of History and Memory, see Laura U. Marks, "A Deleuzian Politics of Hybrid Cinema," Screen 35, 3 (August 1994): 244-264.

89. Haruko Okano, Come Spring (Vancouver: Gallerie, 1992), p.7. 
90. Stan Yogi, "Yearning for the Past: The Dynamics of Memory in Sansei: Internment Poetry" in Memory and Cultural Politics, edited by Amrijit Singh and Joseph T. Skerritt (Boston: Northeastern University Press, 1996), p.253.

91. Ibid., p.158.

92. Ibid., p.246.

93. Rey Chow, Writing Diaspora, p.34, emphasis in the original.

94. Michael Farber, "Two Different Worlds," Sports Illustrated 88, 3 (January 26, 1998): 66.

95. As it turned out, Paul Kariya was unable to go to the 1998 Winter Olympics due to a serious injury.

96. Farber, "Two Different Worlds," p.68

97. Ibid.

98. Ibid.

99. Ibid.

100. Ibid., p.69.

101. Ibid., p.68.

102. Ibid., p.69.

103. Ibid.

104. Ibid. 


\section{Chapter Three \\ There IS No NAME fOR ThIS: The DIfFICULTIES \\ IN REMEMbERING AND NAMING NATIONAL VIOLENCE}

\section{Introduction}

In Chapter One, I mapped out some of the discourses used in historical representations of the Internment. Chapter Two offers an analysis of some of the predominant images of Japanese Canadian women in relation to this history. In Chapter Three, Section One, I will present my research design for this project. The remainder of the chapter will be devoted to arguing two things: the violence of the Internment is difficult to remember and to name because of the violence and its effects; and simultaneously to the production of the violence, its perpetrators discursively and materially normalized and thus masked the violence of their own actions and complicities.

If, as is argued in this thesis, dominant notions of nationhood and subjecthood must be continually re-imagined, we need to understand the role of violence in materializing the imaginary and in ensuring domination. In examining the critical role of violence in these processes, we may better understand how "Violence itself both reflects and accelerates the experience of society as an incomplete project, as something to be made."' Violence was mobilized against Japanese Canadians through legislating their expulsion from the British Columbia coast. It was also instantiated through their incarcerations and the practices of domination, surveillance, control, and exploitation to which they were subjected within their spaces of confinement. I have named these processes national violence to emphasize how the violence of the Internment was used discursively and materially to build the nation and benefit those considered to be its citizens. In concentrating upon the Internment's relationship to nation-building, however, I do not wish to foreclose an investigation of how violence is instigated at the level of interpersonal relationships. Allen Feldman warns us that we may not grasp how violence is mobilized locally if we "simply study power at the 'center,'...from the perspective of formal political rationalities."2 We must therefore also investigate how power is mobilized between people and not theorize power as "external to its effects, external to its 
violence." 3 Violence therefore takes different forms and as will be illustrated throughout this thesis, geographical space is used to obfuscate and naturalize the violence.

In Section Two of this chapter, I will argue that it is difficult for Japanese Canadians to name the violence of the Internment because of its effects, in particular, the psychological trauma experienced by survivors. In Section Three, I will examine some of the ways in which state officials and other non-Japanese Canadians actively produced the forgetting of the violence of their actions while it was occurring, by discursively and materially obfuscating the violence through its misnamings and non-namings.

A fundamental argument of this thesis is that the violence of the mass expulsion procured far-reaching consequences. Violence of this scope has to be obfuscated and forgotten within a nation purported to be benevolent and civilized. The difficulties in remembering and describing this violence by survivors and their children are emblematic of the enormity of the violence and its profound effects, and the pain invoked through remembering its instantiations. Naming national violence is a risky act while living in the nation where it occurs and where our speech acts and representations are continually mediated through relations of power. Despite these risks, the responsibility for naming this violence has more often than not been assigned to the survivors themselves. Remembering, then, for survivors is a tremendous act of courage and a resistance to the hegemony of forgetting.

As a researcher and a daughter of families who were incarcerated, I embody the dilemmas posed in this chapter. When I was a child, I grew up separated from a larger community of Japanese Canadians and the space of family (and extended family) was the only space in which I could hear the namings of the Internment. Despite my parents' numerous and repeated descriptions of this history, when I stepped outside of this family space, I was confronted by a hostile forgetting of what I knew to be a profound knowledge of nation, reflecting a vision of a country and its history different from that which I was taught. I also learned where and when this history could be articulated and witnessed occasions where my parents' understandings of an exclusionary nation were vigorously contested and dismissed. In later years, of course, I too have undergone multiple challenges to the counterhegemonic discourses inherited from my family. 
As a researcher, I have confronted the ways in which this national collective forgetting of the enormity of the violence and its enduring consequences were masked through government reports and documents, weeding through them in the efforts to see beyond the screens of obfuscation and self-aggrandizement. Through this process I have utilised my parents' wisdom imparted to me and I have also been bolstered by the engagement of community members whose intertogations of this obfuscation have contributed to my own ability to name. The forgetting of the Internment has been continually contested by Japanese Canadians through representation and through political organizing such as that witnessed through the redress struggle. Yet, we are also continually negotiating the effects of this violence in our attempts to name it. For example, if we as researchers have difficulty naming the violence and its obfuscation Do we call it "Internment"? Why do some researchers still call it "evacuation"? — how do survivors negotiate the minefields of linguistic masking?

It is through this double subject that I approach this chapter and this thesis, inheritor of both the perpetrators' euphemistic discourses and a collective forgetting of violence perpetrated against many subordinated communities, and the memory of the violence of the Internment passed down to me. I know that I would not have been able to attempt to name without a community of thinkers and artists whose past and concurrent work sustains and challenges me, and I also realize that it is not our responsibility alone to name the violence our community has undergone.

\section{Section One}

\section{Research Design: Women Interviewed}

As a preface to this section it is necessary to state that biographical data for some of the women interviewed, particularly in regards to their current geographical residence and occupation, have not been included in order to protect their privacy. Given the small population of Japanese Canadians - 48,595 (25,195 females and 23,400 males) in $1991^{4}$ - details such as occupation may easily identify some women. The birthplaces of the survivors, however, are presented as reported. The sites of incarceration or forced labour are also named as were reported. One woman, however, requested that the site of her incarceration not be disclosed. The goal of this project is not to write the life stories of 
the women interviewed but rather develop an understanding of how women represent the Internment through memory. I therefore feel the omission of certain biographical details does not affect the intended purpose; uppermost in importance is respecting women's requests for deletion of information that might identify them.

I also wish to clarify my reasons for selecting mothers and daughters as subjects for this study. This was done in order to investigate the cross-generational transmission of memories of the Internment. It was not done to conform to what Lisa Lowe describes as "the trope of the mother-daughter relationship." The privatization and feminization of relations between Asian mothers and daughters, Lowe points out, occurs in the continual aestheticized analysis of the generational dyad as the sole source of cultural transmission and difference. My research does not engage with the psycho-social literature regarding mother-daughter relationships. My aim is to underline the social constructions of gendered and raced subjectivities in two generations of women and interrogate the ways in which knowledge of the Internment is transmitted to children of women who were incarcerated.

I acknowledge, however, this study's lesser attention to the construction of masculinity and its relationship to Japanese Canadian men. Yoshiko, one of the women interviewed, forwarded this criticism when she said, "I feel that it's such a loss, these boys who have so much to give. What does the internment mean [to them]?... they have a whole different perspective that they're not being asked to talk about."6 While I do address masculinity at certain junctures in this thesis, I did not interview men for this study. The problematization of racialized masculinity is an area for further investigation.

Twenty-one women were interviewed for this project. Eleven lived through the west coast expulsion; ten are daughters of these women. I was able to interview three generations of women in one family, Aya, Ann, and Kyo, matrilineally linked, two of whom were incarcerated. This resulted in the uneven number of women interviewed. I also interviewed the patrilineal side of this family, the paternal grandmother, Ann, and her daughter, Mayumi. Thus for one woman, I have interviewed both her maternal and paternal grandmothers.

The women interviewed are described with mother noted first and daughter second. Their ages at the time of their interviews are noted in brackets. Some of them 
selected a pseudonym; others requested that I select one for them. The women are: Ann (82) and Mayumi (42); Aya (77) and Louise (56) and Kyo (26); Haru (72) and Yuko (40); Kazuko (71) and Sylvia (38); Margaret (65) and Irene (36); S. (65) and Midori (27); May (64) and Eiko (44); Evelyn (64) and Joanne (32); Esther (56) and Janice (30); Yoshiko (55) and Naomi (25).

The survivors were of the Nisei and Sansei generations and ranged in age from 55 to 82. The daughters were of the Sansei and Yonsei generations, aged 25 to 44 . I did not interview anyone of the Issei generation for this study. As was stated in Chapter Two, the categories of "Issei," "Nisei," "Sansei" have been used to construct monolithic images of Japanese Canadians. Due to the overdetermined nature of these terms and the ways in which they have been utilised to contain the Japanese Canadian subject through essentialized characteristics and cultural ascriptions, I have decided not to identify the women I interviewed through the repetitive use of these terms.

Through my research, I have learned how these generational categories serve to construct homogeneous subjectivities. The term "Issei" is used for anyone born in Japan who immigrated to Canada. Yet some of the "Issei" may have immigrated with children and thus two generations are categorized under the one term. One woman in my study, Evelyn, was 64 when I interviewed her and is viewed as a Nisei woman. Her paternal grandfather, however, lived and worked in the United States prior to his move to Canada. Her maternal grandparents also lived in Canada. But given that both of her parents were born in Japan, they are identified as "Issei" and as a result she is constructed as Nisei. Yoshiko's great-uncle also lived in British Columbia and died before the Internment. Thus the term "Issei" may in fact be referring to two generations of Japanese Canadians and not just one immigrating generation. Some of the women explained how they feel they don't quite fit into a generational category. Esther reported to me that someone had told her she was "almost like a Sansei."7 She explained how she was the youngest child and her elder sister was like a mother to her. She felt the siblings in her family actually constituted two different generations. In cases where two people from differently designated generations have children, for example an Issei and Nisei, the children may be identified as Sansei or Nisei-Sansei or "two and a half." Given all of these considerations, I have decided not to identify women by these generational categories. 
Class is not an unproblematic category in this project. As Peter Nunoda reveals in his work on political leadership in the pre-Internment community, some Japanese Canadians were middle-class. ${ }^{8}$ Yet all of the families of the women who were incarcerated lost a great deal in terms of the material; all were affected educationally and in their ability to work during and after the Internment. It must be stated that I did not ask questions about women's income in this study. I did, however, ask questions about their occupations, the details of which I am unable to provide. In general terms, they are not a monolithic group in terms of class position and currently some of them have acquired a middle-class social location. It must also be underlined that class is gendered and women's status is often contingent on the earning power of a partner. Some of the women live with male partners, while others are widowed or divorced.

As for their daughters, if education were the determining class factor, they all might be designated as middle-class. All of them had completed some post-secondary education at the time of the interview, some had completed graduate degrees. However, as the Canadian literature on pay inequity indicates, even women with higher education and experience equivalent to men are often paid less than men. ${ }^{9}$ Audrey Kobayashi has also pointed out that "Japanese-Canadian men earn higher average salaries than JapaneseCanadian women" and while suggesting that "subtle problems of discrimination remain for Japanese-Canadian women," she also emphasizes that more research is needed to understand these gendered differences in remuneration for paid labour. ${ }^{10}$ Some of the women interviewed also lived with their parents and were supported, in part, by them. All were employed at least part-time. Some of them were full-time students. Some lived with male partners, others lived alone or with their parent(s). Two of the women interviewed had children.

I found the women for the study through word of mouth and contacts with people in different communities. I knew some of the women and asked them if they would be willing to be interviewed and whether their mothers or daughters would be willing to participate. Many women negotiated these requests with their mothers or daughters, work for which I am sincerely grateful. Some women declined to participate and the deliberations involved in their decisions were also very much appreciated. 
If a woman agreed to be interviewed after the first verbal contact, I sent a letter of introduction regarding my project and confirmed the place and time of the interview. I also explained that I would be tape recording the interviews and would ask that a release form be signed for the use of the interview in my research. I outlined some of the questions I would be asking during the interview and encouraged women to contact me with any questions they might have.

Most of the interviews were carried out between 1994 to 1997. The interviews were conducted in different Canadian cities. I attempted to interview the mother and daughter pair as closely in time as was possibie. Sometimes geographical distance hampered the fulfilment of this goal. One interview was conducted in 1992. This woman was invited to make changes and add comments to her interview transcript in 1997. Her daughter was interviewed in 1997.

\section{Interview format}

A list of questions was prepared for the interviews. All women were asked the same questions. The questions were mainly open-ended, for example, "Can you tell me a bit about your childhood?" and women's responses varied in length. For interviews where there was time, additional questions and issues were discussed. The interviews lasted from one hour to two-and-a-half hours. Most averaged two hours in length. One woman was interviewed twice in order to clarify certain issues. All women were interviewed alone, except for Ann, whose daughter was present with her consent.

Most women were interviewed in their homes. One was interviewed at her workplace and two were interviewed at school. When interviewed at home, women usually served me tea or coffee, homemade delicacies, and often a meal. I made lunch for one woman interviewed in my home. The women's generosity was overwhelming and our sharing food together often inevitably led to discussions about our favourite foods, dishes our families made, and sometimes a sharing of recipes. This was another way in which the women transmitted the knowledge they have acquired. Even the interviews done in more formal settings were accompanied by snacks I would bring and tea or coffee. One woman even packed a lunch for me as I hurried to catch a plane. Another gave me a tin of 
smoked salmon. Another woman sent me home with crafts she had made, some of the items she was making in preparation for a community bazaar.

\section{Ethical issues}

As previously mentioned, each woman was asked to sign a release form granting me permission to use her tape recorded interview in my research. Any conditions piaced upon the use of the tape have been respected. Despite the fact that not all the women requested the use of pseudonyms. I decided out of consideration for the familial and community contexts of each subject, I would not use women's names in my thesis. All women were informed of this decision. My ability to make this arbitrary decision, of course, is reflective of my inherent position of power as interviewer and graduate student.

Each interview was transcribed verbatim in its entirety. Every woman was sent a copy of her interview transcript to review and invited to make changes and deletions where necessary. After I received the edited transcript, I made all of the changes requested. All women were given a photocopy of the transcript with the changes they had requested. In the text of the thesis, I have noted the transcript page numbers so as to enable women to verify the quote with their transcript copy. Each woman will receive the original copy of the audiotape of their interview. Copies of the tape recordings are in my possession until I successfully defend my thesis. Each woman will then decide what will be done with this copy.

It must be acknowledged that in the use of these interviews, I am operating within a context of unequal power. I am clearly the beneficiary of this research, supported by the institutional power of academia. One woman mentioned she found signing a release form very formal, thus drawing my attention to the institutional practices that I enact in my role as a graduate student. My position as a community insider bequeathed on me as a Sansei, daughter of families who were incarcerated, may serve to mask the relations of power that enabled me to enter the lives of the women I interviewed. I am conscious of what Judith Stacey names as the "elements of inequality, exploitation, and even betrayal... endemic to ethnography." " Stacey warns that the greater the sense of intimacy in the interview situation, the greater the risk of betrayal. 
In outlining the ethical issues this research has raised for me, I do not wish to act as an apologist for the clear position of privilege I inhabit as a scholar and a writer. What this work has made me deeply aware of is the great responsibility that one holds in this position and ultimately, the profound gifts that each woman offered to me in agreeing to the use of her interview. I value the considerable thought given by the women interviewed to the ethical issues raised by my research; some women questioned me as to who would be reading my dissertation upon its completion, for example.

I also know that I have selected what is to be presented from women's testimonies. During the interview process, I had control of most questions asked. I invited women to ask me questions if they wished and to also indicate when they did not wish to answer my questions. This process does little to mitigate the fact that I still decide what information is used and how it is interpreted in my thesis.

\section{Testimony and knowledge production}

The dependability of memory and the use of oral testimony in historical writing have been debated in the literature. ${ }^{12}$ My thesis suggests that remembrance and writing history, however, are not mutually exclusive processes, and that much could be learned from exploring how historians' re-membering of their own social locations inform the writing of history. What is cogent to my study is not a preoccupation with documenting the facts of the Internment but rather understanding what is remembered about how domination is produced. Dori Laub's example of historians' dismissal of the testimony of a survivor of the Holocaust due to a "factual" error illustrates how the academic encounter with testimony may reveal our inability to comprehend the layers of meaning in survivor testimonies. In the disputed testimony, the survivor described four chimneys being blown up at the Auschwitz uprising while historians maintained only one was blown up. The testimony was hence discounted for its "inaccuracy." Laub disagreed with the historians' dismissal of the entire account based on what they saw as a factual error, by stating, "The number mattered less than the fact of the occurrence."13

It is the "fact of the occurrence" that is important to my investigation of how women remember the Internment. Nevertheless, I am in accord with Roger I. Simon and Claudia Eppert on the question of the responsibility of the witness to historical trauma to 
attend to "ethical and epistemological responsibilities" through a certain "allegiance with structures of evidence and theorization." 14 In addition to research completed for my master's thesis, I have conducted archival research at the National Archives of Canada (NA) to provide some of the social context for the testimonies. I have also relied upon the historical and sociological work generated by Ann Sunahara, Ken Adachi, Audrey Kobayashi, Roy Miki, and other important thinkers. My theoretical framework will be presented throughout the text of the dissertation.

Most of the empirical information for this study is drawn from the testimonies generated by the women interviewed. It is through this process of interviewing women and listening to their testimonies that I have been struck by the complexities of their experiences and recognize that a testimony is what Shoshana Felman calls a "discursive practice" and does not offer "a totalizable account of....events."1s

The interview process is also replete with moments that are not purely linguistic. but also gestural and pensive; there are emotive posturings that can be lost in the translation from interview to transcript. These non-verbal articulations also convey a sense of the effects and affects of this history, forms of embodiment that also are pertinent to how we think about the transmission of this history to other family members and to children.

This discursive or dialogic process is not a passive one of information exchange. Testimony affects both the teller and witness through its telling; its revelation may trigger memories of both people present. This process also draws on preconceptions both people bring to the interview. For example, I knew some of the women from other activities and brought these insights to the interview process. Some of the women interviewed knew of my literary writing or my participation in different community organizations. These sources of knowledge were also operating and influencing the interview process.

\section{The uses of memory in contesting subordination}

My project situates remembrance as a practice of potential "insurgency"16 and contestation. I hope to trace the formations of a "counter-memory," questioning the homogeneous representation of the Internment and Japanese Canadians, and challenging the hegemony of nation. ${ }^{17}$ Memory is not just about individual remembrance. It is 
connected to community in multiple ways. Re-membering is not an unmediated process and as Roger I. Simon points out "memory [like history] is an extremely selective cultural artifact that can also be a prop of power and authority." 18 With this awareness of the selectiveness of memory, I would like to trace how these memories of the Internment are used to construct subjectivity and nation. I do not, however, propose that memory reconstructs a transparent subject from the past. Rather we can perhaps attempt to understand what the telling of a memory in its complex articulations "reveals about how the past affects the present."19 I will also introduce the concept of "memory of community" in my understanding of women's testimonies, that is how the destruction of communities, and the wrenching apart of families and friends are part of the traumatic space of both re-membering and testifying.

It is within the context of the racialized and gendered silence/speech binary referred to in Chapter Two, that I have had to examine my use of interviews and ask whether my dependence upon oral testimonies could be construed as part of this "othering" narrative. Is my choice of oral testimony as a primary methodology in academic production a reification of speech?

In fact, my project questions the presumption that historical trauma can ever be "spoken" and proposes that the social conditions of our listening are ever informing what is heard and not heard, what is remembered and forgotten. What Gayatri Chakravorty Spivak emphasizes as the "transaction between the speaker and listener" is important to me here. ${ }^{20}$ Relying upon speech as a means to knowledge of violence presumes that the speaker and listener are both liberal subjects able to definitively "know" and "speak." What this analytical presumption elides is the fact that part of the mechanism integral to national violence and the categorization of the "Other" is their disentitlement from the "rights" accorded "deserving" citizens; the model for citizenry is always the white male bourgeois subject, a model that most can never attain. Yet when we witness the testimonies of survivors of the Internment it is this model that is imposed upon them, an enfiguration from which they were categorically excluded through the enactment of violence against them, and we continue to reinscribe this paradigm of domination in judging their testimonies as evidence of their racial and gendered difference. 
I view testimonies as constituting what Lisa Lowe calls a "genre of cultural production," "sites through which subject, community, and struggle are signified and mediated."21 As I have emphasized, however, these are mediated texts and it is my task to understand how they may be "read, understood, and located institutionally."22

My project gestures toward understanding testimonies as constructed rememberings, constituted and negotiated by complex subjects interpellated through systems of domination and subordination within the Canadian nation state. Silence and speech, and the spaces in between should not be relegated to the siting of the survivor alone, but recognized as a spatially-constructed process negotiated multidirectionally between survivors, their families, their communities, and other subjects. In understanding how survivors evoke profound and painful negotiations through testimonies of the Holocaust, Simon and Eppert refer to the "excess," marking "something beyond the limits of what can be spoken through available discourses for articulating incomprehensible violence and human loss. ${ }^{23}$ I would like to shift the solid boundaries delineating speaking and not-speaking and argue that binarily framing the limits of our understanding of national violence in this way is a means of containing its meaning and minimizing the recognition of its impact. I would propose a contestation of these boundaries and the liberal subject that informs and imbues them with particular meanings. Entrenching these boundaries between speech and silence, isolating them as transparent modalities indicative of how the "individual" copes with historical trauma can further isolate survivors of this violence and reify the notion of a normative liberal subject.

As witnesses to testimonies of historical trauma, it is incumbent upon us to "situate the said within the relational encounter marking it as something beyond the merely 'said." "24 In this way we can perhaps come closer to witnessing how women negotiate the naming/not naming/impossibility of naming the Internment. 


\section{Section Two \\ Survivors and Traumatic Memory}

It was quite a traumatic experience, I think, for a family to just up and move. You know, with your belongings.

$$
\text { S. }{ }^{25}
$$

While examining the psychological effects of the Internment upon the construction of memory is not something to which I can attend in any depth in this thesis, it is necessary to acknowledge that the experience of this violence affects the ways in which it is remembered. Two of the women I interviewed spoke directly to the issue of the effects of trauma on memory and their abilities to remember. When I asked May if she had to report to the Royal Canadian Mounted Police (RCMP) upon her arrival in Toronto after leaving Slocan, she responded:

I had to report to the RCMP. I think when I got here. But I don't know if I had to report after that. If I did, I've put it out of my mind. And I'm sure Mona, I'm sure there are things I've put out of my mind because I didn't want to remember them. I'm very sure. But I think that pertains to both my experiences with Japanese or outside the Japanese community. I think there have been things that I've decided to forget. Partly it's a survival mechanism, I think. ${ }^{26}$

Yoshiko was five when she was forced to leave her home in Vancouver. She reported that she cannot remember her life prior to her incarceration in Slocan and she has no memory of her parents packing their things in preparation to leave their home. She states:

Do you know that I can't remember those times. Very interesting. Total blank. And I often consider that as being protected, overly protected that such a terrible thing happened. I can't remember, I can't remember anything about traumatic times with my mother or my father during that time. Wow. Interesting. Can't. ${ }^{27}$

One way psychology attempts to understand the trauma experienced by survivors of violence is through the psychological tool of Post-Traumatic Stress Disorder (PTSD). Various scholars are utilizing this psychological concept in their understanding of testimonies of survivors of the Holocaust and other traumatic histories. ${ }^{28}$ What troubles me in some of the psychological literature and in representations of survivors of historical violence are the ways in which their "trauma" is analyzed in isolation from those who instigated the trauma and the social processes involved in securing domination through 
violence. Through individualized diagnoses of PTSD, the survivor - one who has already been enormously pathologized by the victimizer through the very trauma of violence - risks being re-pathologized in the construing of their behaviours as "disorders." Although I do not undertake here a critique of this literature, I would like to signal my concern that much of the psychological literature on trauma presumes a liberal humanist subject as "client" or "patient," thus scrutinizing their behaviours according to this model of rationality and autonomy. Exploring discourses of psychology and emotion are critical to contesting a "rational" hegemonic subject position, but I feel that isolating the traumatized subject through an individualized examination actually leaves in place the systems that enable violence to occur. I therefore suggest the need for further examination of who is the subject of psychological analysis. I would also ask the questions: why does psychology focus upon the psychologized behaviour of the survivor? What constitutes healing in a context where the violence of domination is continually being enacted? And what would it mean to analyze the psychology of those who violate and dominate. and the normalization of violence in securing domination?

Chalsa Loo has applied her understanding of PTSD in her analysis of the psychological effects of the Internment on Japanese Americans. According to Loo,

PTSD is an anxiety disorder that involved a constellation of symptoms... The traumata commonly involve either serious threat to one's life or physical integrity; serious threat of harm to one's children, spouse, or other close relatives or friends; sudden destruction of one's home or community; or witnessing another person who has been seriously injured or killed. ${ }^{29}$

As is clear from the interviews with women presented in the following chapters, many of the traumata itemized by Loo are applicable to the situation of Japanese Canadians during and after the Internment.

Importantly, the essay by Loo proposes "group treatment" for Japanese American survivors of the Internment. She gives the examples of "pilgrimages" to the sites of incarceration, "days of remembrance" that commemorate important dates in the Internment history, and "house meetings" where participants can gather together to express their feelings about the Internment as "appropriate recovery interventions" experienced by survivors during the redress campaign. ${ }^{30}$ In Chapters Eight and Nine, I 
will raise the question of how women contest the forgetting of the Internment history and will address how it is critical that we create the spaces for this ongoing and crossgenerational contestation.

I would emphasize that I consider the Internment to have been a traumatic event in the lives of Japanese Canadians. This trauma is thus affecting the ways in which women remember and articulate that historical violence. After examining videotapes of testimonies provided by survivors of the Holocaust, Lawrence Langer has theorized that memories of that historical trauma are complexly articulated. In a careful examination of their testimonies, Langer concludes that different kinds of descriptions of the Holocaust suggest different kinds of memory are engaged. Memories signifying what Langer calls "deep memory" will convey a representation of the violence as though being reexperienced, others (common memory) will appear more distant and are informed by the survivor's present situation. ${ }^{31}$ While I do not suggest that Langer's schemata can be transferred to analysing testimonies of survivors of other historically specific atrocities, his work has been usefu! to me in understanding how testimonies are multiply constructed and cannot be construed as simply literal translations of experience. His work also underlines the importance of examining our own preconceptions about testimonial representations of historical trauma. What I hope to accomplish in my examination of testimonies generated by survivors of the Internment is a further interrogation of the interrelationships between the subject of historical trauma, the participants in the violence, and the witnesses to survivor testimonies.

Survivors are always negotiating their memories and are always living with the "danger" involved in their revelation. As was earlier stated, they are reconstructing their memories within and in response to already existing discourses. In an interview situation, there may also be moves by survivors to protect themselves and the interviewer from the trauma of the events they have witnessed. This protective net may skew the ways in which we interpret their words and there may be, on the part of the interviewer, a tendency to diminish the violence that is in multiple ways being communicated, due to their linguistic masking, but also because the enormity of the violence may be difficult for us to bear witness to either as those who have benefitted from this violence or as those who continue to live the legacy of violence. I underline here that subject position and the 
very notion of who is the subject are critical in how we understand survivor testimonies. The issue of who are the testifying subject and witness to testimony will be revisited in Chapter Seven.

I signal the psychological understandings of the effects of violence upon memory only briefly to clarify that I will not be undertaking an evidentiary search for trauma in the testimonies of the women I interviewed. I also will not scrutinize affect in the delivery of testimonies to garner conclusions about trauma or the psychology of the women testifying. Rather I seek to illustrate some of the ways in which women testify to how the Internment was violent and violating, hence demonstrating how the Internment is a profound historical trauma. I will point out what women say about some of the social effects of the violence upon their lives and their memories rather than interrogate the "psychology" involved in the ways in which this violence is expressed. As my project seeks to interrogate how subjects of the Internment construct themselves and who they are presumed to be by others, I am unable to take up some of the larger issues raised by psychology and post-traumatic stress research in particular. I. however, underline that analyses of the psychological effects of the Internment must be further developed and epistemologically connected to research in other disciplines such as sociology and history.

The testimonies generated by survivors of national violence are hence underwritten with the traumatic effects of that violence. It is also important to note how age affects the content of the memories: women who were adults in the 1940s have different relationships to the spaces of Internment than do the children who were incarcerated at that time. As we shall see, the women interviewed ranged in age from three to twenty-nine years when they were expelled from the Canadian west coast. What a twenty-nine year old woman went through during this period, how the Internment was embodied, was different than that of the three year old. Birth order and gender also affect the responsibilities held by female children. This is not to say that children's experiences were easier than those of adults, as it is these kinds of generalities that lead to totalizing accounts of the Internment. Rather, I am suggesting how a consciousness of age will help us further contextualize the abilities of survivors to re-member and name the violence which they all in different ways experienced. 
I will proceed in the Chapter Four by examining the specific spaces of incarceration, forced labour, and displacement as remembered by the women interviewed. I have chosen to do this analysis of the violence of the Internment as a chronology beginning with the expulsion from the west coast and concluding with the dispersal from the interior prison camps and the prairie sugar beet farms. However, I must remind the reader that women's memories were not generated in this chronological fashion and my imposition of this linearity in fact betrays what their memories contest: the notion of time and history as linearly progressive.

Walter Benjamin talks about how the "past can be seized only as an image which flashes up at the instant when it can be recognized." ${ }^{2}$ In my attempt to discuss the spatial arrangements of the Internment, I am imposing a chronology that does not reflect the ways in which "flashes" of memory were generated in the interviewing relationship. I am thus intervening upon the testimonies, not only through my interpretations, but upon the order of time I am placing upon them. This imposed chronology on the memories of the interview subjects collides with my own back and forthing through time in this thesis. Through what may seem a disorienting methodology to the reader, I wish to give a sense of the diverse spaces and timescapes impinging upon memory formation. In so doing, I wish to illustrate how the "past" overlaps with the present both in the generation and construction of memory and in the materiality of our day-to-day lives. I therefore also wish to disrupt the clear delineations between past and present, and illustrate how temporality is also a social construction of containment, and how memories are a testament to how survivors live in multiple time spaces.

Benjamin also discusses how articulating the past is about "seiz[ing] hold of a memory as it flashes up at a moment of danger." ${ }^{\text {33 }}$ I consider the moment of danger for the women I interviewed to be the moments where they experienced the violence, as well as the moments of re-membering and articulating that violence. Re-membering the violence of the Internment and expressing these "flashes" of memory is still not a safe activity for people living within the nation that incarcerated them and where the extent of the violence done to them is forgotten. Understanding that the "danger" exists across these spatial and temporal boundaries and also affects how we as recorders and receivers understand these testimonies will perhaps caution us to attend to our own positions of 
dominance in relation to the practices of witnessing and re-membering. As Benjamin states, the oppressed are not safe from the threat that our memories of "danger" can be used as a "tool of the ruling classes." 34 Thus we must also be aware of the "dangers" for the testifiers inherent in the interview context. Given a situation of unequal power, where the interviewer is a graduate student re-presenting the testimonies within academia, there is much reason for interview subjects to feel unsafe. This apprehension of the "danger" involved in testifying must be understood as part of the constitution of the testimonies.

As we witness to these testimonies of survivors of the Internment, which "image...flash[ing] up at the instant" are we able to attend to? Which conforms to a narrative that is part of a familiar collective forgetting passing as knowing? Is our hearing influenced by how we are implicated in their tellings? If we do not feel implicated, why is this so? And what of their stories will we forget when we are asked to re-member?

\section{Section Three}

\section{Forgetting the Violence of Internment through} Narrating and Materializing the Nation Space

The act of removing 22,000 people from their homes in a matter of months was an act of violence that had profound consequences for those removed. David Goldberg reminds us how the "violence of power and the power of violence" are central to "defining exclusions and inclusion." $35 \mathrm{He}$ also underlines that "violence is inherent in racist expression" ${ }^{36}$ and constituting the other as enemy is to "engage him or her in relations of power." 37

In order to consolidate their unequivocal entitlement to nationhood, white subjects not only participated in this violent process but masked their complicity through various discursive moves. This obfuscation occurred as we have seen, through euphemistic language disguising the wholesale removal of people as an "evacuation." The violence is also rendered invisible in construing various white individuals who participated in its execution, such as those who profited from the Internment, worked in the sites of displacement, used the labour of Japanese Canadians during this period, or who "supported" the government's dispersal policy, as simply motivated by "humanitarianism" or "charity." As legislators, public servants, and other white 
participants carved out the spaces of violence and incarceration in relation to their own entitlement to occupy the space of the Canadian nation, so too did they simultaneously procure the discursive spaces of their own forgetting. And the imagined expansive, collective notion of the white Canadian nation provides the largest space for forgetting the violence on which it is founded, necessitating this selective and repetitive amnesia. Thus white people who participated in materially and discursively constructing the spaces of the Internment also concurrently constructed themselves in relation to these spaces and discourses.

The Internment as a process of violence instigated against a particular community of people is therefore part of a larger picture of nation-building. Violence in its many forms, beginning with colonialism and including the Internment, underpins the consolidation of Canada and serves to construct its citizenship materially and discursively within this white nation space. What will be illustrated in this chapter is how the white elite set up these violent and violating spaces both materially and discursively, and how this organization of space impinges upon the memory formation of survivors. I will also continue to demonstrate how this violence was masked through various discursive moves on the part of the government and non-Japanese Canadian participants in the Internment process. Subjects are produced within these violent spaces and discourses, and that is why in this chapter the discursive relationship between Japanese Canadians and the white participants in the Internment must always be attended to as a relational construct.

According to the 1941 Canadian census, there were 22.096 people of Japanese origin living in British Columbia, most residing in the coastal areas of the province. The census also lists that there were 293,967 males of the "British Isle race" and 277,379 females. Other "European races" were enumerated as 96,602 males and 78,910 females. The category of "Half-Breed - Métisse" included 1,112 males and 1,005 females. There were 12,637 males and 12,245 females designated "Indian and Eskimo." The "Chinese race" was listed as 16,220 males and 2,399 females, and 1.216 males and 541 females appear as being of an "other Asiatic race." The category of "Negro" included 360 males and 300 females. ${ }^{38}$

As a gendered breakdown, the census lists that 9,670 in the "Japanese" category were female and 12,426 male. ${ }^{39}$ Fewer than 900 lived outside of the province of British 
Columbia. By 1 January 1947, only 6,776 Japanese Canadians remained in British Columbia. 13,782 had been moved to other parts of Canada and 3,964 were deported to Japan. ${ }^{40}$ It was not until 1 April i 949 that Japanese Canadians were allowed to live in the one hundred-mile coastal radius of the B.C. west coast.

The disappearance of 22,000 people from their west coast communities and their reappearances in various sites of incarceration and displacement required tremendous structural and legal maneuvering. Ann Sunahara has outlined the government's juridical processes and the role of some of the key governmental decision-makers in implementing the expulsion. What interests me in this section is to reveal how the magnitude of this violence and its long-term effects have been subsequently obfuscated and forgotten. The rapid expulsion from the $B$.C. west coast and the long duration of the period of incarceration required discursive strategies on the part of all who participated in their accomplishment to mask the violence of these acts. While some attention has been given to how Japanese Canadians were constructed throughout the Internment period, little work has been done to show how the Internment was also a process of producing dominant subjects.

I am cognizant of how this construction of a subjectivity of domination is interconnected with the subject formation of Japanese Canadians. This is a relational process; the discourses of domination and subordination are interlocking. One derives the power of whiteness, for example, from the determination the "colouredness" of others is inferior. I am also conscious that the white bourgeois subject as epitomized through his entitlement to nation is always ever informing the construction of our subjectivities as Japanese Canadians. Just as the white subject is always being reconstituted through a collective forgetting of national violences and exclusions, those who are racially subordinated are also reconstructing themselves within and against dominant narratives of nation.

I am using a Foucauldian analysis in my demonstration of how certain discourses used by the state and its citizens impinge upon the memory formation and language used to narrate the Internment history by survivors. Foucault reminds us that "the mechanisms of subjection cannot be studied outside their relation to the mechanisms of exploitation and domination." 41 Thus in this chapter I will trace some of the discursive constructions 
by white participants in the Internment, and echoes of these constructions will follow us through subsequent chapters. In this way, I am recognizing the power of the state in affecting our abilities to remember and name national violence. Using Foucault's notion that relations of power "permeate, characterise and constitute the social body...and cannot themselves be established, consolidated nor implemented without the production, accumulation, circulation and functioning of a discourse, ${ }^{n+2}$ I am also emphasizing the critical role of discourse in our understanding of domination. Discourse, however, is not to be equated solely with the notion of the linguistic or the cognitive. Rather it is the many processes involved in signification that materialize the spaces of Internment, as well as the forgetting of the vioience, both in the past and in the present. ${ }^{43}$

This interconnection between power and discourse emphasizes the productive nature of power as it "induces forms of knowledge and forms of discourse." However, I do not mean to impute a deterministic relationship between elite discourses and the construction of subjugated knowledges. This interpretation would betray Foucault's work; for in fact it is in seeing the complex iterations of power that we can best strategize as to how to contest domination. ${ }^{45}$

What is of interest to me in this tracing of some of the discourses used by the architects, implementors, and narrators of the Internment is how the violence is minimized and even forgotten. How this forgetting of violence is critical to the maintenance of a subject position of domination and hence a collective notion of citizenship and nation is what I will be attending to in this chapter.

Mary Lou Fellows and Sherene Razack have utilized the concept of "respectability" to illustrate how middle-class subjects reproduce relations of domination. They argue that this nineteenth-century intellectual construct describing the "ordered, self-regulating state of bourgeois homes and persons" ${ }^{\text {46 }}$ continues to mark Western social hierarchies in the twentieth century. For these authors, "respectability" is attained relationally: one can only be "respectable" in relation to "degenerate" Others. Thus "respectability is a claim for membership in the dominant group; attaining it, even one aspect of it, requires the subordination of Others." ${ }^{47}$ Fellows' and Razack's concept of respectability will also be applied in Chapter Four when I discuss how the violence of the Internment was disguised spatially. In this chapter, I will argue that even in the face of the 
violence of the Internment, or perhaps because of the enormous implications of that violence, white participants attempted to secure their "respectability" through hierarchically marking the boundaries between themselves and Japanese Canadians and through a discursive forgetting.

While examining in-depth the construction of the white subject in relation to the Internment is not the aim of my project, I am interested in how a hegemonic liberal subject is secured through the violence of the Internment. As my project seeks to interrogate this subject position of domination, I continue in this chapter to call attention to the ways in which the Internment is narrated and materialized in relation to this subjectivity of domination. Forgetting this violence is crucial to the notion of the liberal subject's reproduction of self as "respectable," and it is also critical to his reproduction of self as autonomous.

As Meyda Yeğenoğlu has argued in her critique of the humanist subject in Hegel, the "Other" is critical to the subject formation of the autonomous "Western" subject. Yet this "dependence" upon the inferiorized "Other" must be "repressed" or "forgotten" in order to preserve the "very condition of the autonomy and universality of the subject." I use Yeğenoğlu here to illustrate how while the expulsion of Japanese Canadians from the west coast was critical to the formation of a white nation space, this interdependent relationship and its inherent violence must be forgotten by the white bourgeois subject in order to protect his respectability and autonomy. This forgetting is accomplished both materially and discursively: while the sites of incarceration are readily imagined and materialized, the violence of these spaces must be repressed in order to create the muchheralded "benevolent" and "respectable" collective space of Canada. As people are demonized as disloyal, they are also narrated as having "choices" and "freedom." so as to obfuscate their imposed "difference" by the bourgeois subject who requires yet must deny this very process of differentiation in order to secure his own autonomy. In other words, while the white bourgeois subject creates the "Other's" differences, he must deny his dependent relationship upon her/him. In creating the spaces where violence can occur with impunity, the bourgeois subject must also deny that violence occurs within these spaces and must promulgate the notion that those who inhabit these spaces also have autonomy and "freedom." To acknowledge otherwise would entail admitting how the 
bourgeois subject is implicated in these relations of domination and dependent upon them in the very construction of his own self.

I know that I may be accused of fixing the subjectivity of the "white bourgeois male subject" in my work. I do not think of this subject as an "essence."49 What I am trying to illustrate in my discussions of this dominant subject position are the moves necessary to keep it supreme. I would suggest that dominant subjects are always in the throes of being contested from subordinated subjects and it is the moves to maintain domination that interest me here. I would contend that domination is maintained through violence and my task in this and the following two chapters is to indicate how the Internment as violence secured dominant notions of the subject and the nation. So while I am setting up a certain binary in my work between the white bourgeois subject and the Japanese Canadian subject and run the risk of reproducing that binary. I am trying to illustrate how this bifurcation operates and is essential to the formation of the notion of an autonomous Canadian citizen and nation.

I feel this interrelationship is necessary to explore within any discussion of the formation of the racialized subject, even though my discussion is a preliminary one and not the major focus of this thesis. An analysis of what the Internment secures for white subjects, both in the past and in the present, will help us interrogate the binary of the "villain" and the "hero" (see Ann Sunahara's statement in Chapter One) in the depiction of white participants in the Internment. I will now turn to some of the discourses used by different white participants in the Internment, discourses that served to mask the violence in the processes of expulsion, incarceration, and displacement, and that continue to have currency in the present day.

In 1944, the Canadian Department of Labour congratulated the British Columbia Security Commission (BCSC), the federally appointed body for administering the Internment between 1942 and 1943, for a job well-done. ${ }^{\text {so }}$ The report states: "That this difficult task was done efficiently, economically and quietly in the course of 8 or 10 months is a real tribute to the members and officials of the British Columbia Security Commission." Sl Some may dismiss the three governmental reports, Removal of Japanese from Protected Areas, Report on the Administration of Japanese Affairs in Canada: 19421944, Re-establishment of the Japanese in Canada: 1944-1946, penned by unknown 
authors, as merely propaganda of the government's actions during the period 1941 to $1946 .^{52}$ I would argue, however, that these reports convey particular notions of the Internment to which Japanese Canadians would have been exposed at the time. The same government departments responsible for writing these reports also drafted and circulated the notices of government orders directed at Japanese Canadians. The only Japanese Canadian newspaper to publish during the Internment was the New Canadian, the contents of which "had to be approved by the censor before going to press." 53 Other than journalistic reports and La Violette's book. The Canadian Japanese and World War II, there did not exist published documentation of the incarceration until the 1970s.

In its goal to expel Japanese Canadians from the British Columbia west coast in a fashion as "economical" as possible, the Canadian government created a system of multiple sites of incarceration and enforced labour. That the government's administration of the Internment was driven in part by this economic motive - to save money - is clear from various government documents and secondary sources. Making use of former mining towns in the interior of B.C. must not be seen as an act of humanitarianism in comparison with the system of incarceration in the United States, where prison camps were constructed in the desert and surrounded by barbed wire with those incarcerated eating in central dining halls. Rather, the Canadian decision to use the B.C. "ghost towns" was driven by financial considerations. For example, in 1942, R. H. Webb, LieutenantColonel of National Defence argued that the B.C. interior prison camp system (or what he called "the family system"), utilizing existing abandoned buildings in Greenwood, Slocan, New Denver, Sandon, and Kaslo, would be "the best and most economic" plan. He added that if people prepared their own meals, the government would have fewer expenses: "Central Halls, Central Kitchens will call for wages...Family life will eliminate wages... The family will be encouraged to use initiative, work for themselves, and, consequently, live better and more freely, and incidentally, cut down the cost of feeding them by what they produce themselves."st

Austin Taylor of the British Columbia Security Commission, concurred with Webb's position, at the same time revealing the desolation of the camp sites and the disrepair of the buildings. In a letter to Associate Deputy Minister of Labour, A. MacNamara, Taylor describes the site of Sandon as "practically uninhabited. It is 
probably eighteen years since the houses were occupied... However, we believe this is an excellent opportunity to utilize space at a minimum cost." 55 Add to these comments Ann Sunahara's stunning revelation that proceeds from the sale of confiscated properties were used by the government to pay for the incarcerations and we see how the Canadian state attempted to minimize its own costs. ${ }^{56}$

Other sites considered prior to the decision to use the abandoned mining towns were "Indian Residential Schools." 57 As J.R. Miller has revealed in his study on the residential school system, the BCSC considered using residential schools such as the United Church institutions in Edmonton and Brandon, and the Catholic school in Kamloops for the incarceration of Japanese Canadians. In discussing the proposal to use the school at Brandon, which housed 170 Aboriginal students each school term, Miller quotes government official C.E. Graham who felt, "it would easily accommodate from six to eight hundred [owing to] the way the Japanese can be packed in." 58 These "already available" sites appealed to the government's sense of economy, and their suggested suitability also reveals the spatial interconnections between the colonial practices used against Aboriginal peoples and those promulgated against Japanese Canadians.

At the same time as we must recognize the differences between the expulsion of Japanese Canadians and the violence mobilized against Aboriginal peoples during colonization, and the different effects upon each collectivity, my work suggests that some of the discourses utilized by white bourgeois citizens during the Internment drew upon colonial technologies and practices. What we must insist on in working toward a contrapuntal ${ }^{59}$ understanding of histories of subordination and their interpositionality in processes of nation-building is that Aboriginal people already inhabited spaces of exclusion and marginalization, that is sites such as "Residential Schools." The inclination to call upon these sites as the solution for displacing Japanese Canadians is also therefore indicative of a re-creative gesture of spatial differentiation and domination, hence a repetitive colonial gesture; there is a certain interchangeability of pathologized space and even a sharing of these spaces for those who are marginalized from the nation space. The federal government, however, finally decided not to use the "Residential School" spaces, opting for the abandoned mining towns. 
Sociologist Forrest La Violette described this process of "acquisition of a housing and general housing area" as slow compared to a speedier process that would have required it be done in a "Hitler fashion." violence of the government's actions, for example, the fact that many people were notified in twenty-four hours that they must leave their homes, and that the entire process of removing 22,000 people took less than a year as was admitted in the government's own report. La Violette also elaborates by comparing the Canadian experience to the American and concludes that "There seems to be less display of force" in Canada. ${ }^{61}$

The quotes from Webb and La Violette illustrate how two white men, both participants in the Internment process (Webb who represented the military, La Violette who intervened in the prison camps through his academic project) construct themselves in their own forgetting. The discourse that Canada is a "nicer" place than the United States (or anywhere else for that matter) is part of the construction of this white Canadian self as more "respectable" than other national selves and is part of the ongoing narration of the Internment. In narrating the Canadian self as "more respectable" than the Nazis or the Americans, the metanarrative of respectability must be maintained, thus producing the representation of the Internment in Canada as something other than violence. ${ }^{62}$ Webb's use of the concept of a "free" subject, paradoxical to say the least given the context of incarceration, illustrates how he claims to include Japanese Canadians in a construction of the autonomous liberal subject. This notion of the "freer" Canadian subject is also tied to narrating the Canadian nation as a "kinder, gentler" country, linking it to La Violette's assertions. It is also a narrative that is continued through the discourse of "choice" and phraseology that maintains that Japanese Canadians "chose" their sites of exile. These discourses - freedom and choice - are critical to the maintenance of the notion of the white liberal Canadian subject who lives in a "free" country where everyone has "freedom of choice."

It might be argued that La Violette's and the government administrators' statements are those of the "past." Yet I would suggest that these historical "artifacts" demonstrate a white Bourgeois performance of citizenship in its historical formation, a performance that has resonances with "present"-day discourses. The currency of the selfproduction of Canadians as "kinder, gentler" and "freer" folk continues to be a discursive 
move that enables the forgetting of the complexity and impact of colonialism, social domination, and national violence. What I would like to emphasize here is that when white subjects construct the Japanese Canadian subject and the historical narrative of the Internment, it is always ever about constructing their own subjectivities.

A BCSC report claimed the Internment (or what it called the "transplanting of the great aggregation of the Japanese") was not carried out "without regard to the diverse needs of the people concerned, but at all times [paid] scrupulous attention to the dictates of civilized humanity." ${ }^{\circ 3}$ The fact that the government continually described the processes of forced movement from homes, incarceration, forced labour, and displacement as "civilized" and "humane" indicates a dissonance between how the nation was imagined by those who were the incarcerators and how the nation was lived by those who were incarcerated.

What I would like to signal here is that even while purporting to be "civilized" and "humane," the Canadian state also emphasized how their administration of its policies was "scrupulously attentive" and were used to "control" Japanese Canadians. As Michel Foucault has argued, the claim to "humane" technologies of punishment and imprisonment is the hallmark of the modernist period and reflective of the "moral claims of humanism." 65 The discourse of "humane" punishment also marked a shift from the closed relationship between a sovereign who decided the means of punishment and the condemned who received this punishment to one where the social body became involved in the "power to punish." According to Foucault, "Humanity' is the respectable name given to this economy [of punishment] and to its meticulous calculations."

Foucault's work supports an interrogation of the discursive masking of the violence of the multiple forms of incarceration and punishment. In the case of the Internment, what is often claimed by the government and its administrators to be "humane" and "civilized" treatment also obfuscates the ways in which incarceration was extended throughout the social body of the nation through multiple spatial displacements, engaging thousands of white participants granted powers of surveillance, control, and discipline. One of the ways in which all white Canadians could participate in the Internment process was through the notion of "assimilating" Japanese Canadians, a discourse of social regulation to which I will now turn. 


\section{Assimilation: Re-invoking the Sovereign Canadian Subject}

On August 4, 1944, Prime Minister Mackenzie King outlined government policy on the fate of Japanese Canadians. In this address to parliament, he stated that "no person of Japanese race bom in Canada has been charged with any act of sabotage or disloyalty during the years of war." 68 Yet in a contradictory comment, he added that "those who have shown disloyalty to Canada during the war, should not have the privilege of remaining in Canada." 69 Through this statement, King was setting in motion the process for creating disloyalty, which would take place in the form of the Repatriation Survey. ${ }^{70}$

Prime Minister King advocated that all of the provinces share B.C.'s "problem" and accept those Japanese Canadians moved to other provinces. King presented his policy in this way:

There is little doubt that, with co-operation on the part of the provinces, it can be made possible to settle the Japanese more or less evenly throughout Canada. They will have to settle in such a way that they must be able to pursue the settled lives to which they are entitled, and that they do not present themselves as an unassimilable bloc or colony which might again give rise to distrust, fear and dislike. It is the fact of concentration that has given rise to the problem. The sound policy and the best policy for the Japanese Canadians themselves is to distribute their numbers as widely as possible throughout the country where they will not create feelings of hostility. ${ }^{71}$

In this section I would like to address the government's policy of assimilation in relation to Japanese Canadians and what this secured in terms of creating the spatial configuration of the nation. Through this policy address, King holds Japanese Canadians responsible for the racism directed at them. He attributes the hostility they faced in British Columbia to their spatial location, which he calls a "bloc or colony." In this way, King marks the spatial terrain as clearly one where Japanese Canadians lived outside of the Dominion in a degenerate "colony," and it is imputed that this spatial separation was one for which Japanese Canadians were solely responsible. The discursive construction of the reasons for expulsion as originating outside of the Canadian nation space are also found in a government report naming Japanese Canadians as the "victims of the cruel action of their race," "their native countrymen," who had attacked Pearl Harbor. ${ }^{22}$ Constructing Japanese Canadians as outside of the nation space, as we shall see in the next chapter, disentitled them from the rights of citizenship. It also conveniently turned attention away 
from what was being done within the Canadian nation to Japanese Canadians and how the Internment was not only demonstrative of white imaginings of exterior territories but was also about imagining their own nation space.

King's policy statement associated spatial dispersal with assimilation. The term "assimilation" is another discursive trope of obfuscation that secures a hegemonic subjectivity as the criterion for citizenship. In the case of Japanese Canadians, "assimilation" meant destruction of their communities, separating friends and families, dispossession, and demonizing the self and any attachments to the Japanese language and to Japan. In other words, what was an inherently violent process became normalized through the rhetoric of Prime Minister King, government officials, and all who advocated for the dispersal policy.

In soliciting the "cooperation" of all the Canadian provinces in sharing what had been constituted as B.C's "problem," King also delegated the powers of surveillance and control of Japanese Canadians to the entire nation. Through the promulgation of the discourse of "assimilation," presented as the end goal of spatially separating Japanese Canadians from each other, King's address amounted to advocating that "all citizens...participate in the punishment of the social enemy." was presented as a national project, one where all white citizens could participate in the policing of Japanese Canadians.

As my earlier research has indicated, there was no concerted opposition by nonJapanese Canadians to the government's policy of Internment in the 1940s. Throughout their incarceration and displacements it was Japanese Canadians who organized and who collectively and individually voiced their protests of government policies. The Cooperative Committee on Japanese Canadians, a Toronto-based coalition of predominantly white citizens organized to protest the deportation orders issued by the government subsequent to the Repatriation Survey, supported Prime Minister King's policy of dispersal. So too did the Christian churches who participated in the "resettlement" programs. ${ }^{74}$ La Violette states that "No forceful or sustained opposition had been directed towards the mode of property disposal, travel restrictions, or the many regulations which handicapped the Japanese in their resettlement into normal community 
life." He adds that "Occidentals" "picked up the protests" of Japanese Canadians on the issue of deportation. ${ }^{75}$

Some may argue, as does Ann Sunahara, that there were white people who assisted Japanese Canadians during this period. I do not contest that fact. I would suggest, however, that this assistance, sometimes construed as solely humanitarian, was critical in implementing the policies that the government advocated by enabling the mobilization of certain discourses, including that of "respectability," in the prison camps and in the process of dispersal.

What I would also argue is that the participation of the Christian Churches in the processes of expulsion, incarceration, and forced labour were also reiterations of a specific colonial technology, that of the involvement of missionaries in promulgating the superiority of Western culture and producing knowledges about the people in their "charge." Regardless of their individual opinions on the Internment, the very presence of these workers in the sites of incarceration leant a certain credibility to the processes of Internment. While the topic of how Christianity and other ideological discourses intervened to construct the Internment is too large to deal with in this thesis, I will just give a few examples of how missionaries and other "experts" on the "Orient" participated in the Internment.

Neither kindergartens nor high schools were funded by any level of government in the interior prison camps. As a result, the Christian churches were allowed to establish these schools. According to La Violette, "The teachers sent by churches to the Interior Settlements were mostly returned missionaries from Japan, except in the case of the Catholic group." 76 In addition, he states, "It was hoped by all of the church workers to counter the influence of the Buddhist Church and its close association with Japanese culture and life of the Old Country." $\pi$

That the presence of the Christian churches and their missionaries in the sites of incarceration furthered the notion of the "difference" of Japanese Canadians is evidenced through these descriptions of their "mission." Few white Christian bourgeois subjects would have been unaware of this function of their churches in "foreign" lands. The ease with which the Church engaged "returned missionaries from Japan" to minister to Japanese Canadians also gives a sense of how intranational spaces could be transformed 
to take on the dimensions of the "enemy" nation by moving those who were excluded from the nation space by virtue of their "race" into pathologized spaces, as well as by moving into those spaces those who worked with the Japanese people in Japan. Thus the work of ministering to the Japanese in Japan and the discursive transference of this work to a Canadian context consolidated the construction of the people incarcerated in Canada as "Japanese" and "foreign."

What I also emphasize through this brief discussion is that while these missionaries participated in constructing notions of Japanese Canadians during the Internment, they were also engaged in constituting themseives through these practices. Part of this constitution of self was the role of "knowledgeable" person or "expert" on "the Japanese." La Violette was described by the author of the preface to his book as "acquainted with the Orient." 78 At least one government administrator, George Ernest Trueman, had worked in Japan. Trueman became the Placement Officer for the BCSC in southern Ontario in August 1942. ${ }^{79}$

Whether selected by others or self-selected to participate in the Internment process, these individuals were presupposed to "know" those who were incarcerated due to their work in Japan or on the "Orient." This knowledge formation reinscribed Western claims of entitlement to "knowing" and "teaching" the "Other," practices forged through colonial conquest. It is also presumed that the "Other" was in need of "civilizing," or "westernizing," two colonial concepts often captured by the term "Canadianizing" during the Internment. It is important to emphasize that these individuals were handed the responsibility of "educating" Japanese Canadians and that their role of "teaching" and "ministering" were not benign or solely benevolent acts but existed within a discourse of power relations that sought to construct Japanese Canadians as different and inferior.

Dividing people on Sunahara's axes of "heroism" and "villainy" individualizes the violence and obscures what all white people secure through racial exclusion. Relegating the violence of the Internment to the actions of a few "villains" obscures who and what has benefitted from this violence. While a further examination of the particularities of how individuals benefitted from the expulsion, dispossession, displacement, and labour of Japanese Canadians is needed, my thesis suggests that we must also examine how collectivities benefit from social processes of domination. A 
white individual may not have "directly" participated in the legislation or implementation of the expulsion policies, but white people as a constructed social collectivity accrue power through the discursive and material production of Canada as inherently a country of white citizens. Demonstrating only how the heroes were "respectable" in relation to the villains also masks how the notion of "respectability" was also secured for all white Canadians in relation to the objectification and demonization of Japanese Canadians.

What I would like to point out through this discussion is that the notion of assimilation secures domination. Its normalized assumption is that "Others" must aspire to be and must be forced to act like the dominant subject. Jonathan Boyarin, in his discussion of Jews in the United States, points out that the idea of assimilation also presumes the unchanging nature of the "majority," and that in fact the dominant culture may not be as fixed and secure as the term "assimilation" would suggest. ${ }^{80}$ Hence, the dominant subject must always be recreated through the exclusion of "Others" and it is this white bourgeois subject position that was secured by discursive iteration and material force during the Internment. As we have seen and we will continue to see in subsequent chapters, this process is underwritten with violence of enormous consequence.

In many ways, I too am caught in this struggle with the white bourgeois subject as I reconstruct myself through this dissertation. Critical of a humanist subject position of domination, I am still caught in the discourse of attempting to "rationally" understand what happened to Japanese Canadians through the exclusions and violence of nationbuilding, as though this will ever be understandable to me. I have also constructed myself in my own forgetting as the doctoral student in this study who somehow forgot the pain that this history has caused my own family in asking other women to open themselves to their own painful memories and testify.

It is our attempts to reconstitute ourselves through our re-memberings and forgettings that I am trying to trace through this project. Through this mapping I hope to gain some insight into how a subjectivity of domination might be contested as the only position to which we might aspire. It is to the possibilities for contestation that I will turn in the concluding chapter. 


\section{Difficulties in Re-si(gh)ting the Spaces of Internment}

Another significant site of forgetting for white participants in this process were the designations of the spaces of Internment and displacement themselves. The spatial configurations of incarceration and displacement will be further investigated in the following chapters. What I wish to mention here is one example of how whiteness discursively marked an incarceration site. This is the case of Tashme, named by combining the first two letters of the last names of the first three Commissioners for the British Columbia Security Commission: Taylor, Shirras, and Mead. ${ }^{81}$ One might question the notoriety gleaned from having a prison camp named after oneself, yet it is the symbolism here that interests me. Tashme was the only interior prison camp constructed solely for the incarceration of Japanese Canadians. That is, the name of the site of Tashme and the buildings established upon it were materialized specifically for the purpose of incarceration. Despite the highly racialized nature of this space (or perhaps because of its racial significance), white bourgeois men deemed it important to etch upon it their discursive and permanent mark of ownership. In the tradition of the colonizers whose names litter the sites of their "discovered" nation, Tashme bears the permanent signature of its administrators and to this day remains a town site on maps of British Columbia. This naming is aiso a remarkable signifier of white male bonding, a melding together of patrimonial nomenclatures in the collective forging of violence. Yet, as I am trying to point out in this chapter, their discursive legacy is on the one hand a bold mark of entitlement to ownership of nation while at the same time this proprietary relationship is obfuscated by a discursive masking, in this case using initials rather than full names.

As most of the buildings, shacks, latrines, and other evidence of the Internment have been razed from the sites of incarceration, the names of the camps and the towns to which people were sent take on enormous significance for survivors and their families. This sanitization of the landscape became clear to me during a tour of the B.C. interior prison camp sites in 1992. At the Lemon Creek site, people scoured the terrain for latrine holes in order to reconstruct a picture of the position of shacks in relation to the now empty-of-buildings land. At the Popoff site we were met by a vacant field and quickly gathered around the one woman on the tour who had been incarcerated there. She vividly 
pointed out where the buildings had been and made references to the white people who owned the land, the Popoff's, after whom the site was named.

Joseph Fry has described the Neys "hostel," the site in northern Ontario through which people were dispersed to other destinations, as "covered with mature red pine and campsites for park visitors." 82 The Neys site was used as a prisoner-of-war camp for German prisoners of war prior to its usage in confining and dispersing Japanese Canadians. In regards to the planting of the pine, Fry states, "it has been suggested they have helped to veil the last vestiges of the internment at Neys." He adds, "The names of the local features including Prisoner Cove and Detention Island provide the only lasting hint of what occurred at Neys between the years of 1941 and 1947."83

Thus the significance of these sites and their names must be rendered invisible in a forgetting of how violence has been critical in processes of nation-building. It is profoundly interesting to me how what is in fact an enormous collective "silence" on the part of white people who witnessed and benefitted from the Internment has also been forgotten. Rather than focusing our attention upon the construction of the "rational, speaking, freedom-seeking" white liberal humanist witness to the Internment grown "silent" since the 1940s, our attention has been turned toward re-constructing the "silent" Japanese Canadian subject. One of the women I interviewed. Evelyn, astutely pointed out to me when we were discussing white people's claim to "ignorance" of the Internment, "It was interesting that people didn't know about it. The children were there one day and they were gone the next. Where did they go?"84 Thus not only have the spaces of incarceration been forgotten by physical and discursive maskings, but the very people who inhabited them and the processes through which they suddenly appeared in other spaces have been forgotten through the silence of most of the white witnesses to and participants in the Internment.

It has largely been left to survivors and their children to re-signify the place names of incarceration and forced labour, devoided as they have become of their "other" meanings in a collective national forgetting. One exampie of this spatial re-membering is located in the site of New Denver where the Kyowakai Society has established the Nikkei Internment Memorial Centre. The Centre was officially opened on 23 July 1994 and it includes a museum and an "original internment shack."85 Most Kyowakai Society 
members were in their seventies and eighties at the time the Centre opened and there were approximately 30 Nikkei people, most of whom had been incarcerated in New Denver, living there at the time. I was present for a ground-breaking ceremony during a 1992 tour of the sites of incarceration and was profoundly moved by the people and the work that this site re-members.

Marking the spaces of incarceration with such commemorative structures, even through less visible signs, has not been an easy feat. Roy Miki and Cassandra Kobayashi describe how the Vancouver Japanese Canadian Citizens Association (JCCA) became "embattled" with the Board of Directors of the Pacific National Exhibition (PNE) when a plaque funded by the federal government was to be installed at the entrance to the exhibition grounds marking it as a site of incarceration. The PNE is the location of Hastings Park, the first space of incarceration for 8,000 people before they were sent to other incarceration sites outside of Vancouver. ${ }^{86}$ According to Miki and Kobayashi, in 1987 "Some directors did not want the public to know about the PNE's wartime use, and others argued that the uprooting was justified as a security measure." ${ }^{77}$ The JCCA organized a protest and the Vancouver City Council decided that the plaque would be installed at the entrance of the grounds, "on land beyond the jurisdiction of the PNE Board." ${ }^{88}$ The plaque was finally installed on 1 April 1989, a year after the redress settlement.

Similarly, in the United States, Manzanar is the first and only internment camp site to have been designated a National Park site by the U.S. Congress. ${ }^{89}$ Despite congressional approval in 1988, the site has received no funding from the government and only 320 hectares of the original 2,400 hectares is to be used for commemorative purposes. The Manzanar commemorative site, near Independence, California, was officially opened in the summer of 1998. The opposition to the visible commemoration of Manzanar as a site of incarceration is evidenced through the violence directed at the site superintendent. He reports receiving "five arson threats at the park and endur[ing] such verbal abuse and threats of violence that he has unlisted phone numbers." 90 The responses to these examples of Japanese Canadians'/Americans' efforts to remember the spaces of incarceration through a renaming of the spaces of forgetting illustrate how power and violence are used to actively produce forgetting of national violence in the present and 
that remembering the Internment is not just about relations of domination in the past. Yet even though Manzanar is not on California maps or in guide books, over 80,000 people visit the site every year. ${ }^{91}$ These struggles to remap the sites of the Internment against a cartography of forgetting must be seen as acts of critical importance to generations of the Internment who also continue to resist the violence through embodied commemoration.

The act of contesting a nation's forgetting is also demonstrated by those who remember their own incarcerations. Louise was a child when she, her mother, and three siblings were moved to Tashme. She told me that when she was in grade nine or ten in the 1950s, she read a magazine article on Tashme. It was the first time she had ever seen material on the Internment. She said the article contained a map of Tashme and explained the origin of the place name. As she recalled: "there were three Mounties involved and it was Taylor, Shane - I think it was - and Mead. So they took the two letters of each and that's how Tashme was named." ${ }^{92}$ Louise remembers telling someone about her discovery and his response had been "oh no that's not it." 93 She emphasizes, "But I remember distinctly, I still remember from that article." 94 She also states she wishes to "track this [article] down for Kyo [her daughter] and [her] kids' sake."9s

Louise's story points out how survivors learn about the government and their officials' internal operations - the full extent of the government's violence towards them - years after their actual incarcerations. This is a process that began with their displacement in the 1940 s and continues to this day. For some people, material on the Internment has been largely inaccessible due to issues of language and class. And as was mentioned in Chapter Two, the experience of re-viewing the Internment through various media may be traumatizing and extremely painful for survivors and their families. The traumatizing effects of revisiting this material was indicated by Michi Weglyn, author of Years of Infamy. ${ }^{96}$ Historian Alice Yang Murray reports that Weglyn spent seven years researching for this book and "Sometimes the revelations literally made her sick for days." 97

In addition to the traumatic effects of reading about the Internment for survivors, government records are largely inaccessible to most people due to their location and the processes through which one must go to utilize them. Archival research at the National Archives of Canada, for example, privileges those who have the time and the financial 
resources to stay in Ottawa. Some of the Canadian government's records held there remain restricted and still cannot be viewed by the public. Thus even in a post-redress context, I would argue, there are survivors who have not had ready nor easy access to discourses that are oppositional to those publicly presented by the government in the 1940s.

Louise has also had to live with her memory of reading about the origin of the name of Tashme (vivid and extraordinarily accurate forty years later) as one that was originally contested. I would argue that this denial is emblematic of a larger national denial or forgetting, one which people have had to confront as they left the sites of incarceration and forced labour. They have also had to live within a nation that has destroyed and up until the 1970 s withheld much of the evidentiary proof of their incarceration. It has been largely through the efforts of Japanese Canadians themselves that we have garnered evidence of the Internment. Dispersing people to towns and cities from B.C. to as far away as Quebec has also fragmented the picture of violence and affected their abilities to physically gather together to remember and to name. The denial and the masking of the violence of the Internment has thus extended and compounded that violence.

\section{Conclusion}

Chapter Three introduces my argument that the mass expulsion, incarceration, and displacement of 22,000 Japanese Canadians were acts of violence. To accomplish these actions, extraordinary legislative and administrative measures were taken. Violence so profoundly implicating a nation and its citizens also entails an ongoing discursive masking of its execution and consequences.

I have explored two reasons for the difficulties experienced by survivors in naming this violence. The first is due to the psychological trauma instigated through this violence and the risks involved in testifying to its extent and effects. The second is due to the ways in which the perpetrators of the violence misnamed their actions through euphemistic terminologies and through the contention that the Internment was humanely executed. What must be underlined as we begin to witness the spatial configurations of the Internment is that the technologies used to materially and discursively delimit the 
memory of the violence are in fact reflective of the immense scope of the violence. The trauma experienced by survivors of the Internment is also indicative of the profound and far-reaching nature of the violence.

In response to the ways in which the forgetting of the violence of the Internment is reproduced, I emphasize the necessity in revealing how the violence was spatialized. The spaces of incarceration must be seen as intimately connected to the production of other spaces and the space of nation itself. The cartographies of violence must therefore be remembered through our naming and communal acts of commemoration.

Chapters Four through Seven will reveal how women describe the spaces of incarceration and the interconnections amongst these spaces. The women's testimonies will underscore how systems of domination produced these spaces of confinement and how these very systems were used by non-Japanese Canadians in obfuscating and hence normalizing the violence occurring within these spatial arrangements.

\section{Endnotes: Chapter Three}

1. Feldman, Formations of Violence, p.5.

2. Ibid.,p. 2.

3. Ibid., pp.2-3.

4. Canada, Statistics Canada, Census 1991. Ethnic Origin (Ottawa: 1993).

5. Lowe, Immigrant Acts, p.79.

6. Yoshiko [pseud], interview by author, tape recording transcript, 22 December 1994. p.97.

7. Esther [pseud], interview by author, tape recording transcript, 17 August 1995, p.21.

8. Nunoda, "A Community in Transition."

9. Nan Weiner and Morley Gunderson state, "A comparison between the average earnings of Canadian men and women shows that women are paid only 66 cents for each dollar earned by men." They add, "It is still true that a man with a high school degree is likely to earn about the same as a woman with a college degree." Weiner and Gunderson, Pay Equity: Issues, Options and Experiences (Toronto and Vancouver: Butterworths, 1990), pp. 10-11. I would emphasize that these authors do not address race or racism in their analysis. The position of people educated in countries other than Canada and whose education is subsequently dismissed upon immigration is not examined in their 
statements regarding gendered undervaluations of education.

10. Audrey Kobayashi, “A Demographic Profile of Japanese Canadians and Social Implications for the Future" (Canada: Secretary of State, September 1989), mimeograph. p.48.

11. Judith Stacey, "Can There Be a Feminist Ethnography?" in Women's Words: The Feminist Practice of Oral History (New York and London: Routledge, 1991), edited by Sherna Berger Gluck and Daphne Patai, p. 114.

12. I use Roger I. Simon and Claudia Eppert's definition of testimony, "representations either by those who have lived through such events or by those who have been told or shown such realities." Simon and Eppert, "Remembering Obligation," p.176. For an important analysis of the use of oral testimony and the reliability of memory, see Lawrence Langer, Holocaust Testimonies: The Ruins of Memory (New Haven and London: Yale University Press, 1991), xv.

13. Dori Laub, "Bearing Witness or the Vicissitudes of Listening," in Testimony: Crises of Witnessing in Literature, Psychoanalysis, and History, by Shoshana Felman and Dori Laub (New York and London: Routledge, 1992), p.60.

14. Simon and Eppert, "Remembering Obligation," pp.180-181.

15. Shoshana Felman, "Education and Crisis, Or the Vicissitudes of Teaching," in Testimony, p.5.

16. See Roger I. Simon's argument for "insurgent commemoration," which he defines as "attempts to construct and engage representations that rub taken-for-granted history against the grain so as to revitalize and rearticulate what one sees as desirable and necessary for an open, just and life-sustaining future." Simon, "Forms of Insurgency in the Production of Popular Memories: The Columbus Quincentary and the Pedagogy of Counter-Commemoration," Cultural Studies 7, 1 (January 1993): 76.

17. "Counter-memory" attends to "the heterogeneous systems, which, masked by the self, inhibit the formation of any form of identity." Michel Foucault quoted in David PalumboLiu, "The Politics of Memory: Remembering History in Alice Walker and Joy Kogawa," in Memory and Cultural Politics, edited by Amrijit Singh, Joseph T. Skerritt, Jr., and Robert E. Hogan (Boston: Northeastem University Press, 1996), p.218.

18. Roger I. Simon, "The Pedagogy of Commemoration and Formation of Collective Memories," Educational Foundations, p. 9.

19. Sturken, Tangled Memories, p.2.

20. Gayatri Chakravorty Spivak, "Subaltern Talk," interview by the editors of The Spivak Reader, edited by Donna Landry and Gerald Maclean (New York and London: Routledge, 1996), p.289. 
21. Lowe, Immigrant Acts, pp.156-157.

22. Chandra Talpade Mohanty quoted in Lowe, Ibid., p.157.

23. Simon and Eppert, “Remembering Obligation," p.182.

24. Ibid.

25. S. [pseud.], interview by author, tape recording transcript, 16 August 1995, p. 17.

26. May [pseud.], interview by author, tape recording transcript, 24 March 1992, p.76.

27. Interview with Yoshiko, p.15.

28. For discussions of PTSD as applied to understanding historical trauma, see for example, Cathy Caruth, ed., Trauma: Explorations in Memory (Baltimore and London: John Hopkins University Press, 1995); Cathy Caruth, Unclaimed Experience: Trauma. Narrative, and History (Baltimore and London: John Hopkins University Press, 1996); Judith Lewis Herman, Trauma and Recovery (New York: HarperCollins, 1992); Frank M. Ochberg, ed., Post-Traumatic Therapy and Victims of Violence (New York:

Brunner/Mazel, 1988). For other discussions of the effects of trauma on survivors of historical violence, see for example, Shoshana Felman and Dori Laub, Testimony: Crises of Witnessing in Literature, Psychoanalysis, and History (New York and London: Routledge, 1992); Dominick LaCapra, Representing the Holocaust: History. Theory. Trauma (Ithaca and London: Cornell University Press, 1994); and Robert Jay Lifton, The Broken Connection: On Death and the Continuity of Life (New York: Simon and Schuster, 1979).

29. Chalsa M. Loo, "An Integrative-Sequential Treatment," p.90. See also Donna Nagata's description of PTSD and its relationship to the Internment in Legacv of Injustice, p. 100.

30. Loo, “An Integrative-Sequential Treatment," p.106.

31. Lawrence Langer, Holocaust Testimonies, p.6. Chapter One presents Langer's analysis of "deep memory."

32. Walter Benjamin, ஹluminations, edited by Hannah Arendt (New York: Harcourt, Brace and World, 1955), p.257.

33. Ibid.

34. Ibid.

35. Goldberg, Racist Culture, p.8.

36. Ibid., p.59. 
37. Ibid., p.60.

38. Canada, Dominion Bureau of Statistics, Eighth Census of Canada, 1941, vol.3

(Ottawa: 1946), p.164. While these racial categories are problematic, I quote the language of the census to indicate how race was described and quantified in 1941 . I also wish to indicate who was residing within the space of British Columbia in 1941.

39. Ibid.

40. NA, Records of the British Columbia Security Commission, RG 36/27, vol.41, file 2505, part 1, Canada, Department of Labour, Re-Establishment of the Japanese in Canada: 1944-1946 (Ottawa: 1947), hereafter cited as Re-Establishment, pp. 15 and 25 for calculations of numbers.

41. Michel Foucault, “The Subject and Power," Critical Inquiry 8 (1982): 782.

42. Michel Foucault, Power/Knowledge, p.93.

43. See Meyda Yeğenoğlu's critique of Edward Said's analysis of Orientalist discourses in Orientalism as setting up a "dichotomy between the real/material (which is assumed to be extra-discursive) and the discursive." Yeğenoğlu, Colonial Fantasies, p. 18. I agree with Yeğenoğlu that the "efficacy of the discourse...should thus be sought in its power to produce the phenomenon it names and speaks about" (p.20). The tension that Yegenoglu detects in Said's work also exists in my own when I discuss social domination as being "discursively and materially" produced. I would note that I choose this wording for emphasis but do not constitute the discursive as separate from the material.

44. Yeğenoğlu, Colonial Fantasies, p.16.

45. I am aware that some would debate this interpretation of Foucault and I also concede that his theory can be used to support a more structuralist position. For example, Rob Shields describes Foucault's "discourses" as "totalizing," his theories as having a "totalising tendency" in Places on the Margin (London and New York: Routledge, 1991), especially pp.44-46. See also, Henri Lustiger-Thaler's critique of Foucault in relation to the subject and memory, in "Remembering Forgetfully," in Re-Situating Identities, edited by Vered Amit-Talai and Caroline Knowles (Peterborough, ON: Broadview Press, 1996). pp.209-210.

46. Fellows and Razack, "The Race to Innocence," p. 345.

47. Ibid., p.352.

48. Yeğenoğlu, Colonial Fantasies, p. 5.

49. Ibid, p.2.

50. The British Columbia Security Commission (hereafter BCSC) was established through Order-in-Council P.C. 1665 of 4 March 1942 under the authority of the Federal 
Minister of Labour, Humphrey Mitchell and the supervision of the Deputy Minister, A.J. MacNamara. The BCSC was dissolved by Order-in-Council P.C. 946 of 5 February 1943. The Commission was replaced by the Japanese Division and was maintained under the authority of the federal Minister and Deputy Minister of Labour. See NA, RG 36/27, vol. 42, file 2505, part 1, Canada, Department of Labour, Report on the Administration of Japanese Affairs in Canada: 1942-1944 (Ottawa: 1944), hereafter cited as Administration, p.8; and Oikawa, "Driven to Scatter," p.34.

51. Canada, Department of Labour. Administration, p.5.

52. NA, RG 36/27, vol. 41, file 2505, part 1, Canada, BCSC, Removal of Japanese from Protected Areas (Vancouver: 1942), hereafter cited as Removal. Canada. Department of Labour, Administration. Canada, Department of Labour, Re-Establishment. The latter two reports have been reprinted in Roger Daniels et al., eds., Two Reports on Japanese Canadians in World War II (New York: Arno Press, 1978).

53. Adachi, The Enemy That Never Was, p.267. Adachi, p.268, suggests that censorship affected the journalists' ability to raise criticism of the government's policies and hence it appeared their editorial position was one of "championing relocation." La Violette also mentions that the New Canadian was censored in The Canadian Japanese, p. 162. More work is needed in investigating the discursive construction of the Internment through this newspaper.

54. NA, RG 36/27, vol. 22, file 800, "Slocan: General 1942-1943, 1945-1948," R.H. Webb to Austin Taylor, 29 March 1942, p.2, emphasis added. Austin Taylor was one of the Commissioners of the British Columbia Security Commission. See Ann Sunahara, The Politics of Racism, p.53, for a description of Taylor.

55. NA, RG 36/27, vol. 22, file 800, "Slocan: General 1942-1943, 1945-1948," Taylor to A. MacNamara, 29 March 1942, p.1.

56. Sunahara, The Politics of Racism, p. 105. See also p.71, where Sunahara states that in June 1942, the government was reluctant to intern more men in prisoner-of-war camps because this would be "more costly than confining them in road camps."

57. See, for example, RG 36/27, vol.1, file 17: "Distribution of Japanese," "Memorandum Covering Japanese Movement Pacific Coast, 9 June 1942," p.3.

58. C.E. Graham quoted in J.R. Miller, Shingwauk's Vision: A History of Native Residential Schools (Toronto: University of Toronto Press, 1996), p.385.

59. I am using Edward Said's notion of "contrapuntal" analysis here. As he states, "we must be able to think through and interpret together experiences that are discrepant, each with a particular agenda and pace of development, its own internal formations, its internal coherence and system of external relationships, all of them co-existing and interacting with others." Said, Culture and Imperialism (New York: Alfred A. Knopf, 1993; New York: Random House, Vintage Books, 1994), p.32. 
60. La Violette, The Canadian Japanese, p.63.

61. Ibid., p.64. In contrast, sociologist Tomoko Makabe has argued. "on the whole. the Canadian policy tended to be more severe than the American." Makabe. The Canadian Sansei (Toronto: University of Toronto Press, 1998), p.24. I wish to propose dispensing with the discourse of comparison - which was worst/better/best - between the sites of incarceration within Canada, and between Canada and the United States. While it behooves us to trace how social and material differences were delineated through each site, I am concerned at how the use of the discourse of comparison serves to mask the violence in each site. This discourse of relativity may also support a liberal discourse utilised by nations to suppress criticism of intranational oppression and deflect attention from the transnational construction of relations of economic and social domination.

62. Comparisons indicating that the Canadian government resembled the German National Socialist state were actively suppressed by Canadian officials. See, for example. how the Chief Censor of Publications at the Directorate of Censorship condemned a publication comparing the treatment of Japanese Canadians to that of Jews in Germany for being "against the successful prosecution of the war." In Oikawa, "Driven to Scatter," p.48.

63. Canada, BCSC, Removal, p.17.

64. Ibid. The report also stated that "the transplanting... did not create an exodus of refugees, uncared for and uncontrolled."

65. Michel Foucault, Discipline and Punish: The Birth of the Prison, translated by Alan Sheridan (New York: Random House, Vintage Books, 1995), p.29.

66. Ibid., p.82. See also Goldberg's discussion of this shift and its connection to the emergence of scientific epistemology in Racist Culture, p.2.

67. Foucault, Discipline, p.90.

68. Canada, House of Commons, Debates, 4 August 1944, p.5915.

69. Ibid.

70. The "Repatriation Survey" is described by Ann Sunahara as having two objectives: "to repatriate or deport as many Japanese Canadians as possible, and to disperse the rest across Canada...selecting Japan would be considered 'disloyal,' while the loyalty of those selecting Canada was to be further tested by a loyalty commission." A "loyalty commission" was never established by the federal government. Sunahara, The Politics of Racism, p. 118.

71. Canada, House of Common's, Debates, 4 August 1944, p.5917.

72. Canada, BCSC, Removal, p.2. 
73. Foucault, Discipline, p.129.

74. Oikawa, "Driven to Scatter," pp.85-86. See also Adachi's description of Canadian Christian churches' support for the expulsion and dispersal policies in The Enemy That Never Was, p.219.

75. La Violette, The Canadian Japanese, p.247.

76. Ibid., footnote 22, p.113.

77. Ibid., p.114. For a description of Buddhist organizing during the expulsion, see Terry Watada, Bukkyo Tozen: A History of Jodo Shinshu Buddhism in Canada (Toronto: HpF Press and the Toronto Buddhist Church, 1996).

78. H.F. Angus, preface to The Canadian Japanese, by La Violette, vi.

79. Oikawa, "Driven to Scatter," pp.69-70. Trueman had worked for the Young Men's Christian Association (YMCA) in Japan from 1909 to 1931.

80. Jonathan Boyarin, Storm from Paradise: The Politics of Jewish Memory

(Minneapolis: University of Minnesota Press, 1992), p.82.

81. Adachi, The Enemy That Never Was, p.257.

82. Joseph Fry, “Omoide Garden. Neys, Ontario,” unpublished manuscript, n.d. I would like to thank Joseph for sharing his work with me.

83. Ibid.

84. Evelyn [pseud.], interview by author, tape recording transcript, 26 August 1995. p. 115.

85. Norm Ibuki, "Nikkei Centre, Breaking the Silence," The Bulletin 36, 7 (July 1994):

13. See also "Nikkei Internment Memorial Centre opening in New Denver," The Bulletin 36, 8 (August 1994): 17 (no author given). See also Kirsten Emiko McAllister's doctoral work on the New Denver site, forthcoming.

86. Chapter Four will provide more of a description of Hastings Park.

87. Miki and Kobayashi, Justice in Our Time, p.155.

88. ㅁid.

89. For an account by a woman incarcerated in the Manzanar internment camp, see Jeanne Wakatsuki Houston and James D. Houston, Farewell to Manzanar (Boston: Houghton Mifflin, 1989). A description and photographs of Manzanar are found in John Armor and Peter Wright, Manzanar (New York: Random House, Vintage Books, 1989). Manzanar showcases photographs by Ansel Adams who was invited to take photographs 
of Manzanar in fall 1943. According to Armor and Wright, Adams was a friend of the second director of the Manzanar site. For a critique of Adams' Manzanar photographs, see Creef, "Re/Orientations."

90. Kathleen Kenna, "Land of the Free?" Toronto Star, 12 July 1998, p.E5. It is interesting to note that this article on the Manzanar site was facing a page in the newspaper with an article subtitled, "Case of the 'Asian flu' more like a plague," on the economic situation in Asia. In a literal sense, remembering the Internment is a process faced with racist discourses, like those demonstrated through the association between Asians and contagion. I would like to thank Edward Oikawa for showing me these articles.

91. Kenna, "Land of the Free?" p.E5.

92. Louise [pseud.], interview by author, tape recording transcript, 11 July 1995 , pp.80-81.

93. Ibid., p.81.

94. Ibid.

95. Ibid., p.79.

96. Michi Weglyn, Years of Infamy: The Untold Storv of America's Concentration Camps (New York: William Morrow, 1976).

97. Alice Yang Murray, “'Silence No More': The Japanese American Redress Movement, 1942-1992," (Ph.D. dissertation, Stanford University, December 1994), p.69, note omitted. Frank Moritsugu, writing on the death of Weglyn in April 1999, noted that when Years of Infamy was published in 1976, "Initial reaction included refusal from some bookstores to stock it..." Moritsugu, "In 1976, some stores refused to sell Michi's book," Nikkei Voice, 13, 4 (May 1999), p.5. I would like to thank Dana Y. Takagi for informing me of Murray's work. 


\section{Chapter Four \\ CARTOGRAPHIES OF VIOLENCE: \\ Creating Carceral SPaCes and EXPelling

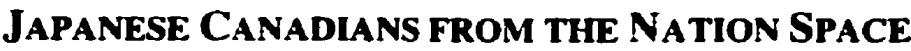

The men are dragged violently into the trains. Father can be seen. He is being pushed onto the train...I see his mouth opening; he shouts to his friends, waves his clenched fist. But the words are lost in all the noise. Mother holds my hand tightly.

Shizuye Takashima ${ }^{1}$

\section{Introduction}

In Chapter Three, I argued that the violence of the Internment is difficult to name due to the discursive and material obfuscations promulgated by its perpetrators and also as a result of the various effects of that violence, in particular, psychological trauma. In this chapter, I propose that the violence is also difficult to see, and hence to name, unless we actually visualize and render visible the spaces in which the violence occurred and the people inhabiting those spaces. With this cartography in mind. we can then more easily conceptualize the social relations and subjectivities produced through these physical spaces.

This chapter will begin to trace the spatial configurations of the Internment and how they are remembered by the eleven women I interviewed who were incarcerated and displaced during the $1940 s^{2}$ An analysis of the production of the spaces of the Internment will demonstrate the enormity of the violence enacted upon Japanese Canadians, and at the same time show how this spatial arrangement serves to, in fact, obfuscate this violence.

I will begin by presenting my methodological approach to examining the spaces of Internment and will indicate how this methodology is critical to understanding how violence was both produced and obscured through these spatial delineations. The remainder of the chapter will demonstrate how the Canadian government used a cartography of exclusionary spaces to set the stage for the dispossession and incarceration of Japanese Canadians living in the coastal area of British Columbia.

I am conscious that the evocation of these embodiments of the violence of the Internment have painful resonances for survivors and their families. We live in a culture 
saturated with violent images, where violence is commodified, and this violence has little to do with acknowledging the effects of violence but rather is often an extension of the forgetting of oppression. While it has not been my intention in this spatial analysis to add to a pornography of violence, I know that in my attempts to describe the effects of the Internment, I am complicit in producing texts that negotiate with difficulty the violence that I have witnessed through this project. As I address my double subject position, my spatializing of self, as a "child of the camps" and as a student constructing myself in academia, I am conscious of the violence I am laying bare to our community and to myself, knowing that the survivors of this violence are more deeply aware of its complex iterations and effects than ever I will be. I am also aware of my distantiated position simply through not ever having lived in the Internment spaces of incarceration and through the many social processes that produce me as a "scholar." My ability to "name" is thus privileged in this work. There is much that $\mathrm{I}$ have disclosed about my knowledge of the violence of the Internment; there is much that I have decided not to articulate.

While it may appear contradictory that I am arguing against forgetting at the same time as I am arguing for a recognition of the unknowability of historical trauma, I feel that acknowledging the latter is actually a way toward the former. In other words, we must struggle with the terms of closure that knowability places upon our understandings of violence and realize the not knowing is intimately related to the violence itself and our different relationships to that violence, and see the possibilities for further interrogation and contestation of the social relations that produce violence. It is clear that the Internment must never be thought to be "known" in its complexity or reduced to a set of descriptors that further mark it as a containable moment of the past, unrelated to our present constitution of selves as Canadian citizens. This is perhaps an uncomfortable position, especially for those who think it is possible and necessary to "know" the "Other." But it is the very liberal notion of knowledge as totalizing that I wish to contest through my work and to profess to "know" the Internment would also be an epistemological act of containing the violence. I would hope that these four chapters on the spatialization of the violence of the Internment will offer some possibilities for imagining other ways of representing this violence and not-forgetting, both through critiques of my work and pursuing trajectories I have touched upon. I am, therefore, 
profoundly aware of the fissures in the cartographies attempted here. As Rob Shields states, "Place-images, and our views of them, are produced historically, and are actively contested. There is no whole picture that can be 'filled in' since the perception and filling of a gap lead to the awareness of other gaps." 3 Detailing some of the embodiments of this violence will never convey its full extent or effect. I welcome an interrogation of the means through which we re-member the Internment, in ongoing efforts to contest the forgetting actively produced within the Canadian nation.

\section{Spatializing the Narrative of Internment}

In Chapter One, I argued that the temporal limitations imposed by the historical narrative relegated the violence of the Internment to the past. If we view history as a linear march of progress through time, we may fail to see the long-term effects of national violence and the multiple ways in which violence is continually being perpetrated against various subordinated communities. In this way, the temporal focus in historical narrative may serve to contain our understanding of this multiply constituted violence and hinder our abilities to see its processes and effects.

In this chapter, I will be using the methodological approach of "spatializing the historical narrative"4 to enable us to conceptualize history as not solely about time but also about space. Edward Soja's work has been important in dealing with the methodological problem of how to contest the forgetting of the Internment. By actually tracing the production of the spaces of incarceration, forced labour, and displacement. we develop a picture of violence simultaneously procured in each site. What this spatial analysis also renders visible is how social relations are both produced through and produce these geographical constructions. Soja calls this spatial analysis an "interpretive geography," a way of recognizing "spatiality as simultaneously...a social product (or outcome) and a shaping force (or medium) in social life." This methodological approach also enables an understanding of how social domination can actually be disguised and normalized. As Soja states:

We must be insistently aware of how space can be made to hide consequences from us, how relations of power and discipline are inscribed into the apparently innocent spatiality of social life, how human geographies become filled with politics and ideology. ${ }^{6}$ 
Soja's work reminds us that space is not "fixed, dead, undialectical"7 but has a critical relationship to the people who inhabit a space and to the spaces and people seemingly exterior to that space. This analysis is particularly useful in understanding the complex spatial construction of the Internment in relation to the now sanitized and "pineforested" sites of the former spaces of incarceration. Keeping in mind that 22,000 people were removed from their homes on the Canadian west coast and incarcerated in different and separate spatial locations, we can then begin to understand how spaces organize different forms of surveillance and how "discipline proceeds from the distribution of individuals in space." ${ }^{8}$ Understanding that spaces and subjectivities are produced in relation to each other underlines the importance of Edward Said's notion of analyzing histories as contrapuntal through their intertwining and overlapping. ${ }^{9}$ What my work seeks to emphasize, therefore, are the ways in which the physical spaces of incarceration, the social processes produced through these spaces, and the ways in which these spaces impinge upon the memory and representation of these spaces are all interconnected. As I trace the spatialization of the Internment through chapters three to seven, I will discuss how these "three spaces (physical, mental, social)...interrelate and overlap."10

While the work of Soja. Foucault, and Said has informed my methodological approach in this chapter, their critiques lack an analysis of gender. The work of Sherene Razack, therefore, has been pivotal in my understanding of the interconnectedness of the spaces of Internment and in turn their relationships to the nation state and the production of a hegemonic bourgeois masculinity. In her essay on the violence of prostitution. Razack posits the critical "relational analysis of bodies and spaces: how social relations constitute the bodies and spaces of prostitution and how those bodies and spaces constitute hegemonic male subjects." "For Razack, "the securing of a dominant masculinity is also the securing of white middle-class elites." 12 What is critical in Razack's analysis is understanding how spaces construct subordination and domination; pathologized spaces are inhabited by people, as in the case of prostitutes, who can be violated with impunity. The bourgeois identity emerging in the late eighteenth and nineteenth centuries "derived his subjectivity from the comparison to the unmanly or degenerate classes." ${ }^{13}$ Thus the spaces of degeneracy are necessary to creating spaces of bourgeois "respectability." The violence that occurs in these spaces through multiple 
social exclusions - racism, male domination, heterosexism, economic exploitation, ableism - is compounded by the violence that these spaces allow, for example, the normalization of notions that the treatment of the people inhabiting these spaces is deservedly lesser than those who do not inhabit them.

In this chapter, I will be using Razack's work to illustrate how the spaces of incarceration and displacement were differentially and relationally constructed. This construction was both material and discursive and entailed the mobilization of interlocking systems of domination - male domination, white supremacy, economic domination, heteronormativity, and ableism - in its accomplishment and obfuscation of the violence. The focus of my work in this chapter is to illustrate how these spatial arrangements produced heterogeneous subjects who remember the Internment in relation to these socially constructed spaces. I will also suggest how these spaces were used to promulgate discourses that serve to normalize the violence occurring within them and how these discourses continue to impinge upon the production of memories of these spaces.

An examination of spatial arrangements is crucial when we keep in mind the making of Canada as a white nation. Securing the white supremacy of British Columbia and of the nation necessitated the continual creation of disloyal and pathologized populations of people of colour who could be spatially segregated. Goldberg has described cordoned off, pathologized areas as "periphractic spaces." The boundaries of these spaces can be physical or imagined and they imply the processes of "dislocation, displacement, and division."14 Goldberg suggests that periphractic spaces have become "the primary mode by which the space of racial marginality has been articulated and reproduced." 15 These degenerate spaces are established in relation to white bourgeois spaces to produce differing entitlements to power.

While Goldberg has written on the configuration of the racialized degenerate urban space as being critical to the maintaining of white bourgeois spaces, ${ }^{16}$ I would also argue that the racialization of rural spaces, such as is accomplished in the Internment and the restrictions imposed upon Aboriginal peoples through the reserve system, are a particular geographical delineation constructed in relation to the métropole that further intends to mark groups as “disloyal," "dangerous," and "degenerate." Such banishment 
from the métropole also marks the rural "uncivilized" landscape as the degenerate spaces servicing the respectability of the urban bourgeois spaces but also testifies to the continuing dominion over the "empty" landscape of the Canadian nation and the triumph of the colonial project.

World War II presented another opportunity to ascribe to people of Japanese origin the mark of disloyalty and thus the pretext for their spatial removal from the coastal area, away from the "respectable" space of the white bourgeois métropole.

Dispossessing them of property and other possessions, and discounting the citizenship of even those who were born in Canada were moves that normalized their disentitlement to the Canadian nation. hence their Canadian statelessness was manipulable to the ascription of belonging to the nation of the "enemy." White bourgeois men, such as we witnessed in Chapter Three, easily imagined and rationalized that Japanese Canadians should live in restricted spaces of incarceration, detention, and servitude. Japanese Canadians were thus barred from the one hundred-mile restricted coastal area and from the imagined white collective space of the Canadian nation.

Audrey Kobayashi uses a spatial analysis to describe the imposed "placelessness" of Japanese Canadians and Aboriginal people in Canada. Using a human rights discourse, Kobayashi situates the denial of geographic rights, a "right to place," in the hands of the Canadian state, where concentrated power is utilized to control space. She names racism as the "mechanism through which the power to deny geographic rights is released, and the ideological channel through which the contest of spatial control is negotiated."17 Kobayashi enumerates three ways in which geographic rights can be denied or limited:

...one, exclusion, by which certain groups are denied spatial access to designated places, either entire countries or parts of countries; two. restriction of the freedom of movement from one place to another, or of the presence of designated persons in specific places and times; three, expulsion, whereby designated groups are removed from a place and subsequently excluded and restricted. ${ }^{18}$

As Kobayashi states, this "spatial discrimination" was imposed upon Japanese Canadians, particularly between the years 1942 and 1949. She, however, emphasizes that the spatial exclusions that transpired during this period were but a "logical extension" of a 
fifty-year history where geographical rights were denied through a "social context of racism." 19

As Kobayashi contends, spatial designations for Japanese Canadians occurred long before they were removed from the west coast. Kay Anderson's argument that the formation of "Chinatowns" was a means of controlling racialized communities and that they were not naturally occurring could also be applied to the Powell Street area, a visible Vancouver Japanese Canadian community in the pre-Internment period. ${ }^{20}$ Tracing the specificities of excluding Japanese Canadians from white spaces in the pre-Internment period is a project deserving of much greater attention than I am able to provide in this thesis. ${ }^{21}$ It is important, however, to mention the pre-existence of these spatial exclusions in British Columbia through material boundaries and also the juridical technologies used to disallow Japanese Canadians, and more generally, all Asians and Aboriginal people, from voting in municipal, provincial, and federal elections. Banned from the voting lists, they could by default be excluded from holding public office, becoming lawyers, pharmacists, architects, and chartered accountants. ${ }^{22}$ Both spatial and discursive constructions of entitlement to white spaces secured the exclusion of Japanese Canadians from the nation state. I would also argue that it was the perceived threat to these white spaces, the seepages that were occurring as some Japanese Canadians became more economically able to move into other areas of Vancouver and the province of British Columbia and were organizing to fight for the vote and the rights of citizenship, that a white Canadian nation strove to control through the violence of Internment. ${ }^{23}$ As Kobayashi states, "The dominant notion that Asians should keep their place both geographically in ethnic ghettos and socially became stronger as Japanese-Canadian citizens attempted to secure a place beyond these realms." 25 What better way to mark a racialized community who were striving to attain entitlement to the rights of nation than to further spatially enunciate their difference through imprisonment and spatial confinement? 


\section{Creating a Nationless People}

Canada's entry into World War II gave the pretext for greater and greater spatial restrictions placed on all people of Japanese origin living in the country. The Canadian government used the War Measures Act to authorize the wholesale removal, detention, incarceration, dispossession, and deportation of Japanese Canadians. ${ }^{25}$ Orders-in-Council issued by the federal government clearly specified where and when they could travel. For example, on 8 December 1941, all fishing boats were impounded, thus claiming the waters as out-of-bounds. Order-in-Council, P.C. 365 issued on 16 January 1942 designated a one hundred-mile "protected area" from the Pacific Ocean to the Cascade Mountains and from the Yukon to the United States border. ${ }^{26}$ Order-in-Council P.C. 1486 then allowed the Minister of Justice to control the movements of all people of Japanese origin in "protected areas."

Delineating the allowable times for Japanese Canadians to be outside of their homes was a step toward spatially separating them in prison camps and far-flung regions of the nation. A "dusk to dawn" curfew imposed on all people of Japanese origin on 28 February 1942 limited their access to public places and to each other, thus curtailing their abilities to gathar together in numbers and to work outside of daylight hours. ${ }^{28}$

Community infrastructures supporting communication and intracommunal relations were hastily dismantled and rendered illegal by the federal government. As Terry Watada states, "Japanese community newspapers and language schools were closed, public gatherings were forbidden, churches could no longer hold services although funerals were allowed."29

Haru, who lived in Vancouver in what she called a "Japanese community," was forced to leave her home with her family when she was eighteen. She asked me if I was aware of the curfew imposed on them prior to their move. She described how the curfew divided people and how marginalization within a nation can be differentially lived:

Haru: We had a curfew. You heard about the curfew? We couldn't go out after ten o'clock...the Chinese could go but they all wore badges.

MO: What did the badge say?

Haru: They're not Japanese. ${ }^{30}$ 
Haru also contextualizes the fact that Canada was at war with several countries and wonders why the treatment of other communities was different:

But I couldn't understand because the war was with Italy and Germany too. And yet they never went through [mass expulsion]. Japan was the last to get into the war. ${ }^{31}$

Ann Sunahara has pointed out that while German Canadian and Italian Canadian leaders of organizations were detained, the federal government "resisted demands in 1940 by the Great War Veterans Association to intern all German and Italian aliens." 32 However, it is clear that 597 Italian Canadian men were interned at the Petawawa prisoner-of-war camp. ${ }^{33}$ Franca lacovetta has described how the Casa d'Italia. the "centre of fascist activity" in Toronto was seized by the government and 200 men were interned. ${ }^{34}$ The Royal Canadian Mounted Police (RCMP) also monitored the Italian Canadian community in Toronto and some people "stopped speaking Italian and anglicized their names." 35

What is important to note from Haru's testimony is her understanding of how these three communities, historically linked to the Axis powers during World War II, were differentially treated by the Canadian government. While all three communities struggle to piece together from government files and testimonies the extent of statesanctioned violations launched against them, perhaps future projects could also examine how we, as marginalized communities, were/are hierarchized within the Canadian nation. How do our interconnected en-genderings and gradations of racialization construct us relationally and for what purposes? Understanding the contrapuntal interconnections raised by Haru's question might provide another way of conceptualizing race and whiteness as shifting categories, as our "differences" are imagined and discursively operationalized in relation to national tensions.

When S's family was forced to leave Vancouver, she was twelve. She described to me how they lived in a predominantly white area of the city and had close associations with white neighbours and Japanese Canadians, most of the latter living "downtown." When I asked her how she remembered leaving Vancouver, she responded by telling me what happened before leaving and how the curfew affected her family and their "downtown" friends. During this stressful time, her family supported those who could not 
make the curfew by housing them overnight. This support ensured a means of gathering together during the days of immediate upheaval and uncertainty.

MO: And do you remember your parents being asked to leave Vancouver? Do you remember how that happened?

S: I'm not sure exactly how it happened. I know there was a great deal of talk. Friends would come over. And we would hear all the news of what's happening downtown and I can't remember the exact time that they were told or how it affected them. Well I know they were quite upset at the time. But it always involved other friends who were going through worse circumstances than ours'... We had more people staying over at our house because we lived far away from the downtown area. They would come to visit us and they'd stay beyond the curfew time. So, we'd have people staying at our house. Just to get back home the next day. ${ }^{36}$

Evelyn, who was eleven, remembers her first encounter with the notion of war was the war between England and Germany. She remembers buying "war savings stamps" and "bugging" her parents for the twenty-five cents to purchase them. ${ }^{37}$ When war was declared on Japan, there was a "rush of activity." 38 She remembers the curfew being imposed and how one of her neighbours "got caught" for being outside after dusk. 39

May, on the other hand, remembers that she was treated differently than the adults at the time the curfew was imposed. She was thirteen and lived in a predominantly white neighbourhood. She remembered a time when she was able to come home as the day was losing light or after dusk because she was "in the middle" of a group of neighbourhood white children. ${ }^{40}$ She, however, also lived with the stress of being punished for breaking the curfew and described this one incident:

I remember seeing a policeman and being just slightly panicked, wondering well like was I going to go to jail or what was going to happen. And he just simply turned a blind eye. Because he was a neighbourhood policeman..."

The fear of being caught outside after the curfew was also expressed by Shizuye Takashima who lived in Vancouver and recalled hurrying home with her sister after seeing a movie. Takashima's remarkable book, A Child in Prison Camp, conveys the profound anxieties she observed and felt as a child and the day-by-day erosion of their lives as the restrictions were imposed. In this instance, a man threatened to call the police when he saw the two young girls and told them to "Get off our streets!"42 Takashima described how their worried mother greeted them and in explaining their tardiness, her 
sister stated, "I'm sorry. The film was longer than I thought. It was so great we forgot about the curfew."43

\section{Dispossession}

In understanding the connection between space and rights, how those who are displaced and without rights are relationally constructed to those who have a place and sense of entitlement, Sherene Razack's analysis has been useful. As she states:

... women without a place...cannot speak "in the language of power and assertion and staked claims" as can those who posssess property and home...paradoxically, it is property and home that men secure in treating the bodies of displaced women as places where violence can occur with impunity. ${ }^{44}$

In the case of the Internment, part of the process of creating a "placeless" and hence "nationless" people was to dispossess them. Being without place would ensure their uncontestable disentitlement to the rights of citizenship. While Japanese Canadians were already excluded from many of the rights of citizenship prior to the Internment, I would argue that the processes of dispossession and displacement from their homes served to strip them of any legal recourse, ensuring the continued abrogation of their claim to legal rights well into the future. Thus we see how dispossession and dis-placement go hand-in-hand in the legislation aimed at controlling Japanese Canadians. Some of the legislation aimed at their dispossession and how this dispossession was lived by particular women will be outlined in this section.

Order-in-Council P.C. 288 put in place a three-man committee responsible for the disposal of fishers' boats. ${ }^{45}$ On 8 December 1941, 1,200 fishing boats were impounded and placed under the control of this Japanese Fishing Vessel Disposal Committee. ${ }^{46}$ All property people were unable to take with them was placed in the custody of the Custodian of Alien Property. ${ }^{47}$ Order-in-Council P.C. 1665 of 4 March 1942 stated that the property was under the "control and management" of the Custodian. ${ }^{48}$ Motor vehicles, radios, and cameras were confiscated by the government. Allowed to take only 150 pounds of baggage per adult and 75 pounds per child over twelve with a maximum allowance of 1,000 pounds per family, the possessions left behind were often looted or destroyed. Thus 
dispossession began well before the issuance of Order-in-Council P.C. 469 on 19 January 1943 allowing the Custodian to liquidate all property under its control.

I will further analyze the concept of "dispossession" in Chapter Eight, but in this chapter I would like to illustrate some of the ways in which women talk about what they consider to have been their losses. My analysis regarding the concept of dispossession is that gender must be taken into account in how we understand what women report as "their" losses. What has not heretoforth been analyzed in the Internment literature is the gendered relationship to property and how this particularized condition of "ownership" affects what people will report as having lost during the Internment years. If, as was the case for many women, they did not own title to boats or property, they may very well not report these items as being lost or confiscated even if these possessions were owned by fathers or partners. Gender is also connected to class in these constructions of ownership. As Peter Nunoda reveals, in 1931 approximately two thirds of Japanese Canadians were working class, eighteen percent of whom were designated as "unskilled." Many of these people did not own property. ${ }^{\text {so }}$ Not owning property is always constructed in relation to those who do and this relationship will also affect the ways in which people will talk about the material losses they suffered. In other words, there is always a consciousness of how other people might have lost more as defined in terms of property, especially by those who owned little in the pre-Internment period. Given a context where the focus of dispossession has largely rested on the material tangibility of loss as opposed to potentiality, those who did not possess according to these criteria may also tend to minimize their losses. ${ }^{51}$

Clearly much property was lost in the massive confiscation of everything other than the "one bag" that most people were allowed to take with them. A study conducted by Price Waterhouse of Vancouver published in 1985 generated the figure of a loss in total for the community at $\$ 48$ million in 1948 dollars or $\$ 443$ million in 1986 dollars. $^{\$ 2}$ Importantly, this study did include a calculation for income loss. However, the researchers deemed it inappropriate to include a figure for "lost education" or "nonpecuniary" losses. Also, the accounting firm did not estimate for losses attributable to the "dispersal." What is of interest to me in this and subsequent chapters is what women report as their losses, losses often less tangible than property, and how the invisibilization 
and normalization of these losses are part of the violence undergone both in the past and in the present.

Haru recalled that "what little furniture we had, we had to sell it for next to nothing." 53 Kazuko, who was seventeen when her family was forced to move, described how they were allowed to carry one bag per person:

...the Mounties came and said that we're going, "Here's a notice." And we opened the notice and it said, "You have to leave this place in twenty-four hours. And just one baggage to a person." So we didn't have much time at all. Because this wasn't expected. .4 $^{54}$

Kazuko, however, is also conscious of the position of her parents and adds: "So that was, mostly for my parents, that was really sad. You know, everything, you lost." 55

These "adult" reports are to be contrasted to that of a woman who was a child at the time. Margaret, who lived in Richmond, was forced to move to Manitoba when she was twelve. When I asked her about leaving her home she told me all she could remember was that they had to leave their dog.

The only thing that we, the kids remember, was our dog. We couldn't take our dog. So we had to give our dog away. Of course, our dog came back the day before we left. So we did end up bringing it to Manitoba. We didn't know what else to do. ${ }^{56}$

Some of the women who were children at the time of the expulsion situate themselves within a childhood memory, less encumbered by what they report as the hardships of their elders. Yet when they do discuss their elders' losses, there is often a profound grief, reflective of the enormity of the loss. This age-specific self-situatedness may not be comprehended by those who hear these testimonies. We may expect the adult before us to report what an adult might have experienced over fifty years ago. That is, we do not recognize that memories from childhood and the language in which they are expressed may be different from those who were adults, and that some adults may have attempted to shield children from the violence in all of its complexity.

The ability to take something cherished with her was an important memory for Margaret, yet when she describes her family's losses, she articulates them in relation to those who were older, who lost "their" possessions. This ability to situate the self relationally to others is a theme to which I will return throughout this chapter. As Margaret states: 
We were only allowed to take one baggage each. So, my grandmother had a lot of heirloom things. The government said, "You have to move, you have to leave everything. It'll only be a matter of year and a half, two years tops. Leave everything and you're only allowed one baggage." We had this woodshed which locked. So my grandmother put everything in there, locked it up, hoping, you know, within a couple of years to come back and claim it all. But when my brother went back after the war, they had smashed in the windows, taken, smashed everything that they could smash and took whatever was valuable. So, we had nothing left. I think that was the hardest part for my grandmother. Cause it was all family things that she had left. That was very hard for her. Well, that's war. Yeah. I think a lot of people went through that, anyways, you know. It's not just us. ${ }^{57}$

It is important to notice here how Margaret describes her grandmother's losses as "family things." They symbolize a relationship to others. She also situates herself within a context of "war" where others also suffered losses.

The relationships conveyed through this chapter spanned time and space, connecting people across national boundaries through history and family. Yoshiko, who was only five when she was forced to move from Vancouver, cannot remember her family leaving the city. ${ }^{58}$ She knows her parents owned a car and that "very few people at that time owned cars." 59 The way their losses have manifested for her is through her knowledge that they no longer have things she remembers being a part of her familial surroundings before they were forced to move from Vancouver. The evidence of these possessions is materialized through the photographs they have retained from this period. She states: "We have pictures of us, our home in Vancouver before we moved. You know, those shelves of dolls, Japanese dolls? And things on the walls. We don't have any of that." 60

S., who was twelve at the time they were forced to leave Vancouver, describes the process of dispossession in this way,

...we always thought we would go back. So, I can remember my mother packing boxes, which we left with the neighbours, thinking we would claim them. All our good Japanese things. And things we just didn't want to take. ${ }^{61}$

In contrast to Yoshiko's experience, however, S.'s family did eventually get the possessions they had entrusted to their neighbour. 
Esther, who was also around three at the time, does not remember the home she left in New Westminster. She describes how her parents lived in a float house and that her parents never bought any property. As she states, "perhaps it was just as well they didn't. Because it was confiscated anyways, right." ${ }^{62}$ In contrast to Yoshiko's family, Esther's did not own car. She describes how her "father had a fishing boat. And my two oldest brothers had a fishing boat." ${ }^{63}$ Her family left their other possessions in the float house and asked a "Polish man," nearby to look after them.

Evelyn, who was eleven at the time, remembers her father trying to reassure the children that leaving Vancouver would be "like a holiday." 64 Her father's business contact bought his boat from him. Evelyn describes this loss of her father's boat in relation to the loss sustained by other fishers: "Yes. We were lucky. You see most of the people's boats were confiscated. But they bought my father's boat." to sell their furniture to the neighbour "for next to nothing." 66 She remembers one possession, in particular, that was very difficult to give up - her father's violin. Evelyn states, "he did seem sad. He, I think, gave it to the neighbour's daughter."67

May remembers that the day the hakujin ${ }^{68}$ auctioneer sold all of their household goods was the day they also moved into Hastings Park. May's father had died just before Canada's declaration of war against Japan. Although her family lived in Vancouver, they were moved to Hastings Park in June 1942. She was fourteen when she, her mother, and sister left their home. She describes how they were dispossessed and moved to their first site of incarceration, all in one day:

So I finished my school year in June and then we sold all our furniture and stuff. By then my father was dead, you see. So there was a Japanese man, maybe there was more than one, who together with a, I think he was an auctioneer, a hakujin auctioneer. And they would come around, we got word that there were these people available who would come and give you a price for everything in your house and they just simply came and moved it out on a certain day. And on that day then we went into Hastings Park. So that we could be moved out from there. It was the Manning Pool. And by this time my mother was very sick. She was extremely sick. She had done some housework after my dad died because she needed some money. ${ }^{69}$

Part of May's family's dispossession was the pilfering of a private insurance plan her father had skipped lunches to purchase in the years preceding his death. A white 
lawyer had approached her mother upon her father's death and her mother asked his advice on what to do with the money. This is what happened to their insurance policy:

When the evacuation notice came, mother went to talk to [the lawyer] and he had said, "they're going to tell you to use your own money up, you know, before you can go on welfare. So maybe if I hold this, because you are certainly going to need some monies over and above welfare." So this is what we did, we went out and bought things like blankets and things that would be needed for warmth and spent some of that money. But then we left the rest of the money with him. Unfortunately what we did not know was that he was an alcoholic. And so he never seemed to have the money to send us after we got in the camps. Those were some of the kinds of things that feel bad to me. Heck if that was going to happen why didn't Daddy just go and eat lunch, you know. I mean he would have been better off to have eaten it, you know. ${ }^{70}$

\section{Connecting the Sites of Internment}

When we think of the Internment of Japanese Canadians (if we are at all aware of what that means) we may think of the detention camps in the interior of British Columbia. But are we aware of the differences between the prison camps, their geographical specificities and the ways in which divisions were created within each site? For example, in the case of Sandon "high in the hills north-west of Kaslo and east of New Denver," the government's own report described it as "reached by a narrow, winding, steeply graded road...difficult to negotiate in the winter..."71 The annual snowfall for Sandon was twenty feet and the town had two to three hours a day of sunlight. ${ }^{72}$ When I visited this site near the middle of October 1992 on a tour of the interior prison camps, the town and environs were snow-covered. The bus driver was unsure that he could negotiate the road safely. Someone on the tour who had been forced to move to Sandon told me it was referred to as the "hell hole."

There were also other sites of incarceration: Hastings Park (what for many was the first site of incarceration in Vancouver); the so-called Self-Support Communities; the various work camps to which men were sent; the prisoner-of-war (POW) camps in Ontario to which some of the men were sent; Neys hostel in northern Ontario and other hostels in Saskatchewan, Manitoba, Quebec, and southern Ontario. As part of the Internment, I also include sites of enforced labour such as the sugar beet and other farm 
work on the Prairies and Ontario. In connection to the Internment, through the government's forced dispersal process, I include the domestic service and other jobs that women and men were driven "east of the Rockies" to accept in the face of joblessness in the camps or the threat of deportation to Japan when the Repatriation Survey was conducted. ${ }^{73}$ And there is also the most geographically distant site of expulsion: Japan, the country from which some visiting Japanese Canadians were not allowed to leave during the 1940 s and the country to which over 4,000 people were forced to move through the coercive signing of the Repatriation Survey. ${ }^{74}$ My use of the term. Internment, is not just about temporality but also about materiality, how expulsion and restriction get constituted through different spaces and how these practices are disguised through liberal discourses.

What I wish to underline is how the discursive construction of the sites of incarceration through the interlocking of discourses of domination and subordination served to further obfuscate the materiality of violence. The complicated fragmentation of the sites of Internment reduces our ability to understand them as violence. The systems of domination that produce material differences existed through these particularized sites of incarceration. And it is these "scattered hegemonies"75 and also the lack of a counterlanguage to describe these processes of incarceration and its effects that contribute to a national forgetting.

The constitution of the Internment as a multiply spatialized incarceration hinders our very ability to see these spaces as imprisonment and hence facilitates the forgetting of the violence produced through these diverse spaces. Nevertheless, I would emphasize that the sites to which Japanese Canadians were sent by the government were "carceral""76 spaces, where their movements were restricted and monitored.

As I stated in Chapter One, much more work is needed to understand the interconnectedness of these sites in constructing the Internment narrative. It is the enormity of this task of historical research that underlies my urging that we, as Japanese Canadians, continue to undertake this work. As I have already made clear, I feel this knowledge will always be partial and historical research is but one way of materializing the Internment and its significations. It is on the one hand the totalizing discourse of "knowing" that I wish to disrupt while on the other encouraging people to continue to 
conceptualize and materialize its meanings as one means of counteracting a collective forgetting.

It is the very fragmentation of historical research, the effort needed to go through voluminous files at the National Archives of Canada, for example, just to find information on one site that is indeed reflective of the fragmented process of the Internment and its national significations. The massive holdings in the National Archives of Canada testify to the ways in which individuals and communities have been monitored and displaced. It is this very fragmentation that has also served to disguise the violence: the distantiated process rendered the isolated geographical situations of each site less visible to politicians who ordered their necessity and thus protected themselves in many ways from witnessing the actions they had legislated. ${ }^{77}$ The use of euphemistic language at that time also distanced the government and its administrators from the realities of their actions and left a semantic legacy with which we continue to struggle.

The difficulty in tracing these hegemonic relations is also connected to the discursive disguises in the Internment narrative, for example, Webb's phraseology from the document in Chapter Three and his use of the term, "family system," to describe the prison camps. While occluding the fact that many men were forced to work and live outside of the prison camps, this terminology also operates to secure a particular notion of family that excludes non-nuclear family and other forms of intimate relationships, including a network of relatives, lovers, and friends. It works to invisibilize how many of the women, men, and children were "missing" and "missed" in the different sites, as they were separated over time and space, some never to be reunited.

This discourse of the family was also used in promoting the site of the sugar beet farms and the "self-support" communities as a way of "keeping families together." What gets occluded in this narrative is the fact that families as were constituted in the Japanese Canadian community were enormously disrupted in moving to these sites. As my interviews illustrate, Evelyn, re-moved to Lillooet, a "self-support" community, had to separate from her maternal grandparents who were moved to the Lemon Creek prison camp. Aya, who was married at the time, was moved to Greenwood and Tashme and reported that her mother and brothers were moved to a sugar beet farm in Manitoba. 
The women I interviewed see and articulate these interconnections through their relatedness to each site. For example, Haru, who was incarcerated in a B.C. interior prison camp, reported to me that she knew that life in the "self-support" communities was difficult because one of her relatives had lived there. Yet it is also this very awareness of the hardships inherent in each site that affects a survivor's ability to name her own experience as uniquely difficult. This memory of an entire community expelled and how one constructs oneself in relationship to it is something to which I will continue to refer to in my work as "memory of community."

Women struggle to name the interconnections between the different sites because their lives were touched by all of them in varying ways. This awareness of the conditions of other sites and the partners, lovers, parents, children, friends, acquaintances, and families who inhabited them serve to inform their memories of that experience. They are thus also aware of the multiple elisions - who is missing and missed - in the predominant Internment narratives.

Joy Kogawa's novel, Obasan, is noteworthy for numerous reasons, including its representation of the sites of both a camp (Slocan City) and a sugar beet farm and the movement of a family from one to the other. While I am unsure as to whether many families were moved from camps to sugar beet farms, Kogawa's rendition of displacement conveys a sense of the multiple movements comprising the Internment. What struck me in the interviews I have conducted are how the women were moved from site to site, sometimes from camp to camp, and often separated from different family members and friends in this continual displacement. All of this occurred after the initial traumatic removal from their homes. Although historians of the Internment have struggled to name the processes of expulsion, I think the term "second uprooting"78 used to describe what is sometimes referred to as the "dispersal" from the interior camps does not quite capture the multiple movements that transpired after 1941.

Each description of the site of displacement gave me but a glimpse of life in its complexity but also of the horrors, material and psychological, of those sites. Each departure, including the one from "home," to unknown spaces of confinement and restriction, from familiar geography to changing landscapes and climates, was a leaving 
of cherished people and all the people who had surrounded them, a weeding through again of ever diminishing possessions, and was replete with the accumulation of loss.

\section{Work Camps and Prisoner-of-War Camps}

The government mobilized a particular notion of racialized masculinity to produce the site of the work camps through Order-in-Council P.C 1271 issued on 13 February 1942. I would argue that this first removal of men who were Japanese Nationals, as well as the creation of the prisoner-of-war (POW) camps as a site for men who were Japanese Nationals and Canadian citizens, depended upon the heightened image of a demonized and racialized masculinity, that of the "enemy" or "alien," constructed to legitimate their incarceration. While more analysis of the representation of Japanese Canadian masculinity is needed, it is evident that racializing discourses depicted Japanese Canadian men as "Other" in relation to a normative white bourgeois masculinity. The spectre of the "disloyal Japanese" had to be continually made tangible to white Canadians and the notion of disloyalty was discursively used in the construction of the sites of incarceration. The government accused those detained in the Petawawa and Angler Ontario prisoner of war camps - what they called "Internment camps" - as "those Japanese known to be dangerous, or to have the slightest subversive tendencies and, therefore, considered to be a potential menace."79

As has been documented by Sunahara and others, ${ }^{80}$ many of the men forced into POW camps were those who protested the separation of their families through the expulsion process. In particular, the Nisei Mass Evacuation Group (NMEG) is often cited as an example of resistance to the governmental order calling for the break-up of families. ${ }^{81}$ While the resistance of these men in the face of violence and all of its potentiality is undeniable, it interests me that this action is one of very few in Internment narratives signalled as "resistance." As Nunoda has pointed out, little is known about the women's group, the Nisei Mass Evacuation Women's Group, formed in April 1942 to support the interned men and "resist evacuation." 82 There is also little mention in the literature or in community commemorative representation of women's "resistance" during the Internment. For example, the actions of Mrs. Tanaka-Goto who refused the orders to leave her home in 1942 and was incarcerated in Oakalla prison before being sent 
to the Greenwood prison camp have largely remained unacknowledged.$^{83}$ Other than Muriel Kitagawa, very few women (and men for that matter) have been constituted by Japanese Canadians as resisting the violence of the Internment.

As I investigate the spaces of incarceration in subsequent chapters, I will underline how women negotiated the multiply constituted violence of displacement. Using Foucault's argument that "wherever there is power, there is resistance," continue to interrogate the very notion of resistance, contesting representations of resistance that preclude a complex understanding of subjectivity in relation to violence. I wish to question the binary delimiting our notion of resistance to $a$ set of actions on the part of an individual resister or group of resisters constructed in relation to other actions denoted as non-resisting (and sometimes categorized as those reflective of an attitude of “shikata ga nai"). In this way, I seek to broaden our notion of resistance to include an analysis of how people negotiate the social processes of domination and how space impinges upon these negotiations.

The demonization of Japanese Canadian men and their spatial separation were critical to the government's legitimization of the Intermment and forwarded its notion that Japanese men were essentially "different" from white bourgeois men and inherently dangerous. In utilizing the prisoner-of-war camps, the government also created another category of people the government deemed as "internees" and it used this distinction to then categorize other sites of incarceration as other (less severe) than "internment." 8.5 Ann Sunahara has demonstrated, the government was also careful in describing those born in Canada as "not interned," even those who were in POW camps, since only "aliens" could be legally interned according to the Geneva Convention. ${ }^{86}$

Adachi states, 1,700 male nationals, through P.C. 1271 were eventually moved to work camp sites and of them two-thirds were married and had an average of two or three children. ${ }^{87}$ Canadian-born able-bodied men were soon to follow, sent both to camps in Ontario and British Columbia. ${ }^{88}$ In total, 2,150 men were sent to road camps in British Columbia and Ontario, and many of the men who lived in the prison camps were also forced to do labour and returned sometimes on the weekends. ${ }^{89}$

As was previously mentioned, males over the age of thirteen were separated from women and children in Hastings Park. It was thus assumed by the government that 
women would care for the remaining children, not "able-bodied," and elderly in Hastings Park and in the prison camps to which they were eventually sent. What I would like to emphasize here is the gendered presumption - women must care for children, the disabled, and the elderly - was mobilized by the white Canadian state and materialized through the separations of men from the sites where these activities took place. While the government may have, at times, rendered women invisible, as in the case of a 1942 government report where women and children were listed as one category of the "Canadian-born," operationalization of the Internment. Although some of the Internment literature alludes to the patriarchal practices of "Japanese," Japanese Canadian, or Japanese American men. there has been little analysis of how male domination and gender-specific roles were secured through practices enacted by the white politicians, public servants, Internment administrators, and other participants in this violence. It is important to also note here that a category of physical ability was iterated through the Internment as some of the men who were sent to the interior prison camps were defined as "not able-bodied."

Just as the removal of men constructed Japanese Canadians in relation to a white hegemonic able-bodied masculinity, so too did it produce a white hegemonic femininity. The separation of racialized women from their partners, lovers, children, parents, siblings, extended family, friends, and neighbours also privileged the continuity of white spaces where particular arrangements of family and community were assured of their entitlement to occupy these spaces. While the removal of many men from families with children ensured that women assumed the childcaring function also prescribed in hegemonic maledominated family structures, Japanese Canadian women's subject position was not unitarily similar to that of white bourgeois women. White bourgeois women also clearly benefitted from the exclusions that the violence of the Internment produced. How the Internment reinforced hierarchical arrangements among women will be further demonstrated in Chapters Five and Six. 


\section{The Pathologized Space of Hastings Park}

The first site of incarceration for 8,000 people, ${ }^{91}$ particularly those who did not live in Vancouver at the time of the expulsion, was Hastings Park Manning Pool in Vancouver. Sunahara describes it as "a holding pen for human beings...converted from animal to human shelter in only seven days...the ever-present stink of animals and the maggots and the dirt...encrusted the buildings in Hastings Park."92 Sunahara's research on Hastings Park must be contrasted to a government report describing Hastings Park as "At all times...kept scrupulously clean." 93 The report also stated that "Many valuable lessons in food values were learned by the Japanese during their stay in Hastings Park and while they were there every effort was made to educate them to the correct standard of proper diet. Sanitary and laundry conveniences and all the more simple accoutrements of modern civilization were installed." 94

The notion of modern Western "civilization" is critical in the construction of the incarceration of Japanese Canadians. As Meyda Yeğenoğlu states in her analysis of Western colonialism, "the very production of this modernity and universality is based on a fundamental contradiction, for the imposition of modernity in colonial conditions was predicated on the denial of freedom and autonomy to native cultures." 95 While Yegenoglu's analysis is specific to the context of colonialism, I would argue that modernism and the liberal humanist subject underpin the spacial structuring of the Canadian nation and its denotation of citizenship.

Just as in the colonial project, the colonized must be shown to be "uncivilized" and "backward," white government officials (as above) continually referred to the need to "civilize" or "Canadianize" Japanese Canadians. Spatially segregating Japanese Canadians created the pathologized spaces needed as "proof" of "degeneracy." In this way, the white bourgeois subjects created colonies to be conquered "within" their nation; separate and largely inaccessible spaces to which they could travel discursively and materially in order to reconstitute their own entitlements to nation.

The construction of Japanese Canadians as "disloyal" hinged upon the Orientalist notions of their Otherness and this difference had to be discursively repeated in the attempts to justify the violent actions volleyed against them. Yegenoglu delineates how temporality is used to legitimate the violence of colonialism by rendering the colonial 
project as one which seeks to modernize and raise to the "advanced" moment of the colonist the "backward" and "primitive" Other. I would extend her analysis to spacial as well as temporal constructions of domination and superiority, and specifically those spacial exclusions experienced by Japanese Canadians during the Internment. Separation from family and destruction of community were continually legitimized by the state and citizenry in the goal of assimilation (read Civilization). Confining Japanese Canadians to pathologized and dehumanized spaces secured the respectability of the white bourgeois subjects outside of these spaces and those who inhabited them not by force but by "choice." In seeking to obscure the violence of incarceration and displacement, the white bourgeois subject secured for self the notion of being "civilized" and the continual repetition of the assimilation discourse was essential to occluding the violence inherent in incarceration and forced spatial displacement. To paraphrase Yeğenoğlu, "the dissimulation of the violence" was secured in the guise of "dissemination of the benefits of modernity to uncivilized cultures." 96

Kazuko's comments shed light upon what was deemed as "modern civilization" by the government. They also reveal what "valuable lessons in food values" were imparted:

The first place where we went was Hastings Park, with lots of other people. You know, you just sleep on the floor and....the sugar was rationed, so even when you got porridge, the sugar was not even a teaspoon full. And milk didn't even cover the porridge. Porridge was like a paste. You know because it was so many people to cook for. And then also we had to help with the dishes afterwards, which is natural. But the meals were, oh gosh, I'm telling you, were like, you wouldn't even feed it to a dog. It was just terrible. So we were very happy to get out of there. ${ }^{97}$

Haru, who was also forced to move from Vancouver, described her memories of

Hastings Park in this way:

The men were taken first to Hastings Park. My father and my mother, then even in Hastings Park we couldn't stay together. The men were all in one building and the women and children were in another building. That was an experience. And then once you're there, it's like a prison. There was a gate, you couldn't go out. You had to get a special permit to go into Vancouver if you wanted to go and do some business. And so our lives were: you slept in a horse building or manufacturer's building where they had bunks. And they gave you blankets that you could put a rope on to make a partition. And it was very hard because there were hundreds of 
people there and you didn't know who they were. They came from all over Vancouver and Vancouver Island. They were total strangers. Regardless of how hot, how rainy, we had to go to another building to stand in line for hours to get our food, for breakfasts, lunch and supper. And we all got a tin plate. I can remember that it was so hot one day. By the time you got there, you just thought you were going to pass out, just to get your supper. ${ }^{98}$

Haru begins her description of the horror of Hastings Park by describing how the men, including her father were "taken" and separated from the women in this first site of incarceration. Men (and boys over the age of thirteen) were separated from women in Hastings Park. According to Sunahara who speaks of the married men here, "They were prohibited from entering the building housing their wives and young children." 99 This site, where single and married men were restrained and separated from mothers, partners, sisters, and children served therefore to normalize white masculinity by pathologizing the racialized male. I would also argue that through the acts of determining that Japanese Canadians were disentitled to live with partners, families, and in communities, these violent displacements and removals of men bolstered a white bourgeois heteronormativity by privileging white entitlements to a particularized white bourgeois "nuclear family" and "community," thus securing a hegemonic raced and gendered heterosexuality. ${ }^{100}$ Rather than reifying this hegemonic notion of the family, I will continue in this thesis to examine how this white bourgeois social construct is secured through multiple exclusionary practices. It is through a hegemonic dialectical arrangement of race, gender, class, and heteronormativity and its unquestionable right to "dominion" over property and nation that was to be defended through the violence of the Internment.

Haru's testimony emphasizes the relational in describing who was missing from Hastings Park and also the fact that "there were hundreds of people and you didn't know who they were." May also felt isolated as she was confined in Hastings Park with her mother and sister. She told me how she knew no other people in Hastings Park. Her sense of isolation was reinforced by a memory shared by her sister-in-law decades later at the funeral of her mother-in-law. May describes how her sister-in-law (who she did not know during the Internment) confessed this recollection to her:

She said, “You know, May, I've been meaning to tell you because I think I've had a little bit of a guilty conscience. When you were in Hastings 
Park, I remember you and your sister and your mother sitting in the shade of a building in the afternoons. And you would be sitting there listening to a portable record player. We used to run past you and call names." I don't remember that particular incident, except that I knew that we were out of sync. ${ }^{101}$

May tells me that she does not remember this particular incident but hearing it reinforced for her "that it was not just me that was internally feeling out of place. That I must have looked out of place." 102 What May's testimony points out again is the disruption of relationships that the Internment enacted. What is also stunning about this sharing of memory years after the Internment is how the memory of the Internment and displacements is continually being built across time and space. Due to the violent disruptions in relationships, survivors may encounter people they knew or with whom they shared a space of incarceration and in whose presence they have not been since the rupture of their displacements. These reunions for many survivors are ongoing, particularly for those who renegotiate Japanese Canadian spaces, and thus the spaces of memory may be filled in through these encounters continuing over fifty years after the Internment. How do people live with the anticipation of such meetings, filled as they may be with emotive contradictions, embedded within a re-engagement with traumatic memories? And by contrast, how do they wrestle with the absences of those who are missing, never to be seen again?

On 30 September 1942, the Hastings Park prison site was closed. ${ }^{103}$ The 8,000 men, women, and children incarcerated there were moved to other sites of exclusion and containment.

As well as the people and the violence forgotten through a national collective imagining of the nation as white, there also is forgotten the ways in which people contested violence. Muriel Kitagawa's writings provide an account of this contestation in the site of Hastings Park. As someone who was not incarcerated in the Manning Pool, she was differently situated in relation to the violence occurring there. Due to her friendship with someone who worked in this site, she learned of one woman's protest to a white nurse upon finding maggots. According to Kitagawa, the nurse responded, "Well, there's worms in the garden aren't there?"104 
Kitagawa's friends publicly challenged this nurse who was known to call people "filthy Japs." ${ }^{105}$ Kitagawa's friend Eiko also protested the actions of a white RCMP officer who began to hit women in Hastings Park when they congregated at the entrance to their "cage" to learn about what was happening to the men who were refusing to be sent to the Schreiber, Ontario work camp. ${ }^{106}$

La Violette, who witnessed the violence in Hastings Park as someone who was white, described how the hostility of those being confined to this space, "became converted into demands upon the Security Commission for improvement." 107 Some of these demands were articulated in a petition dated 19 June 1942 addressed to the representative of the international Red Cross in Montreal and authored by a group confined in Hastings Park. This petition included the following demands, "emancipation from unneccessary restrictions, the rights of the democratic nation, freedom of speech...sympathetic understanding of an oppressed people, differential treatment for Japanese nationals and Canadian citizens, appointment of a medical officer for Hastings Park, and the return from work camps of the husbands of expectant mothers." 108

As stated in Chapter One, these demands on the part of Japa zese Canadians were pathologized by La Violette. In describing the attempts to organize and protest in Hastings Park, he compared Japanese Canadians to Japanese Americans incarcerated in the United States who were labelled as exhibiting a "demandatory psychology" by American internment camp administrators. ${ }^{109}$

How the forgetting of the multiple and varied forms of contestation was accomplished will be further investigated in the following chapters. It is extremely disturbing that what was witnessed as varying forms of "resistance" to violence have been reduced to a depiction of Japanese Canadians as exhibiting a "shikata ga nai psychology." The pathologizing of Japanese Canadians is, therefore, not simply a practice of the past. What is also clear is that these unidimensional portrayals also serve to conceal the violence of the Internment as our focus is turned toward the reductive image of the "silent" survivor in lieu of asking more complex questions about the silence of the perpetrators. 


\section{Conclusion}

In this chapter I have argued for the importance of a methodology that spatializes the historical narrative. By rendering visible the spaces of the Internment, we are able to see how spaces were used to both construct and hide the violence of incarceration. Spaces are therefore critical in producing the remembering and forgetting of national violence.

Through systematic dispossession and displacement, the government ensured the placelessness of Japanese Canadians and their exclusion from the rights of citizenship. Separating the genders was a process of engendering that served to secure a hegemonic white masculinity. In the next chapter, we will look more closely at the sites of the B.C. Interior prison camps and how the Internment was a process of en-gendering for women.

\section{Endnotes: Chapter Four}

1. Shizuye Takashima, A Child in Prison Camp, n.p.

2. The eleven women are May, Evelyn, Yoshiko, Esther, Haru, S., Kazuko, Margaret, Ann, Aya, and Aya's daughter, Louise.

3. Rob Shields, Places on the Margin, p. 18.

4. Edward W. Soja, Postmodern Geographies: The Reassertion of Space in Critical Social Theory (London and New York: Verso, 1989), p.l.

5. Ibid., p.7.

6. Ibid., p.6.

7. Ibid., p.11.

8. Foucault, Discipline, p.141.

9. Said, Culture and Imperialism, p. 18.

10. Soja, Postmodern Geographies, p.120.

11. Sherene Razack, "Race, Space and Prostitution: The Making of the Bourgeois Subject," Canadian Joumal of Women and the Law 10 (1998), p.341.

12. Ibid.

13. Ibid., p.360.

14. Goldberg, Racist Culture, p.188. 
15. Ibid.

16. Goldberg, Racist Culture, Chapter Eight.

17. Audrey Kobayashi, "The Historical Context for Japanese-Canadian Uprooting," in Social Change and Space, edited by Ludger Muller-Wille (Montreal: McGill University, 1990), p.70.

18. Ibid., emphasis in the original.

19. Ibid.

20. Kay Anderson, Vancouver's Chinatown (Montreal and Kingston: McGill-Queen's University Press, 1991). For descriptions of the Powell Street area, see A. Katsuyoshi Morita's Poweil Street Monogatari, translated by Eric A. Sokugawa (Burnaby, BC: Live Canada Publishing Ltd., 1988); and Audrey Kobayashi's walking tour of the Powell Street area, Memories of Our Past: A Brief Walking Tour of Powell Street (Vancouver: NRC Publishing, 1992).

21. For descriptions of pre-Internment spatial, legislated, and social exclusions. see Ken Adachi, The Enemy That Never Was, and Audrey Kobayashi, "The Historical Context."

22. National Association of Japanese Canadians, "The Case for Redress Information" (Toronto: National Association of Japanese Canadians, n.d.), p.2. See also Ken Adachi, The Enemy That Never Was, pp.52-53.

23. See Ken Adachi's description of the Japanese Canadian Citizens League's organizing drive and efforts to win the franchise in 1936. Adachi, The Enemy That Never Was, pp.160-164.

24. Kobayashi, "The Historical Context," p.74, note omitted. See also, La Violette's description of Vancouver Alderman Halford Wilson's proposal in early [941 (before the bombing of Pearl Harbor) that Japanese Canadians be segregated into a ghetto. La Violette states that the proposal was based on the claim that Chinese Canadians were moving into the "newest" and "most exclusive" areas of Vancouver. He further states, "A by-law was drafted for the purpose of requiring Orientals to live in "their recognized localities." The Canadian Japanese, footnote 5 I, p.51.

25. Canada, Statutes of Canada, 1914, 5 Geo.V, c.2. For a description of the use of the War Measures Act during World War I and World War II, see Ann Sunahara, "Legislative Roots of Injustice," in In Justice: Canada, Minorities, and Human Rights, pp. 7-22, edited by Roy Miki and Scott McFarlane (Winnipeg: National Association of Japanese Canadians, 1996).

26. Adachi, The Enemy That Never Was, p.209.

27. Ibid., p.216. 
28. Ibid., p.232.

29. Watada, Bukkyo Tozen, p.107.

30. Haru [pseud.], interview by author, tape recording transcript. 23 November 1995. pp.38-39.

31. Ibid., p.39.

32. Ann Sunahara, "Legislative Roots of Injustice," p.17.

33. Maria De Angelis describes the incarceration of Italian Canadian men in "Testimonies: Internment, Racism and Injustice in Canada," in In Justice, edited by Miki and McFarlane, p.25. She adds that men were also incarcerated at three other internment camps: one at St. Helen's Island in Quebec and two in Fredericton, New Brunswick. She states that the total number of men incarcerated is unknown.

34. Franca Iacovetta, Such Hardworking People: Italian Immigrants in Postwar Toronto (Montreal and Kingston: McGill-Queen's University Press, 1992), pp.143-144.

35. Ibid, p. 144.

36. Interview with S., p.12.

37. Interview with Evelyn, p.23.

38. Ibid., p.25.

39. Ibid.

40. Interview with May, p.19.

41. Ibid.

42. Takashima, A Child in Prison Camp, n.p, emphasis added.

43. Ibid.

44. Razack, "Race, Space, and Prostitution," p.358, note omitted.

45. Adachi, The Enemy That Never Was, p.209.

46. NAJC, The Case for Redress, p.2.

47. Ibid., p.218.

48. Ibid., p. 233.

49. Nunoda, “A Community in Transition," p.58. 
50. Ibid., p.59.

51. See Nunoda's discussion of the 1940 CCJC fight for compensation for losses sustained by Japanese Canadians. Nunoda contends that initially the CCJC advocated fighting for lost income as well as property losses. This demand was eventually dropped. Nunoda argues that by dropping the claim for lost income, "the CCJC was already predisposed to ignoring a large segment of working class claims." Nunoda, "A Community in Transition," p.287.

52. National Association of Japanese Canadians, Economic Losses of Japanese Canadians After 1941 (Winnipeg: National Association of Japanese Canadians, 1985), p.1.

53. Interview with Haru, p.42.

54. Kazuko [pseud.], interview by author, tape recording transcript, 19 October 1995 , p.12.

55. Ibid., p.13.

56. Margaret [pseud.], interview by author, tape recording transcript, 20 June 1955, p.27. I would suspect that few people were allowed to take their family pets with them and I believe this was permitted in Margaret's family's case because they were sent to a sugar beet farm.

57. Ibid., pp.28-29.

58. Interview with Yoshiko, p.15. See also Chapter Three where she describes not being able to remember the pre-Internment period.

59. Ibid.

60. ㅁid., p.15.

61. Interview with S., pp.15-16.

62. Interview with Esther, pp.16-17.

63. Ibid., p.17.

64. Interview with Evelyn, p.27.

65. Ibid., p.67.

66. Ibid., p.30.

67. Ibid., p.31.

68. The English translation of hakujin is "white person." 
69. Interview with May, pp.24-25.

70. Ibid., p.26.

71. Canada, BCSC, Removal, p.20.

72. Watada, Bukkyo Tozen, p.115.

73. See, Oikawa, "Driven to Scatter," Chapter Two.

74. Ibid., p.68.

75. Inderpal Grewal and Caren Kaplan, "Introduction: Transnational Feminist Practices and Questions of Postmodernity," in Scattered Hegemonies: Postmodernity and Transnational Feminist Practices, edited by Grewal and Kaplan (Minneapolis and London: University of Minnesota Press, 1994), p.7.

76. Foucault uses the term "carceral" to describe various spaces where people are punished, disciplined, and monitored: "The "carceral' with its many diffuse or compact forms, its institutions of supervision or constraint, of discreet surveillance and insistent coercion..." Foucault, Discipline, p.299. Ann Maria Alonso also uses this term in "The Politics of Space, Time and Substance: State Formation, Nationalism, and Ethnicity," Annual Review of Anthropology 23 (1994): 394.

77. For discussions of the distantiated processes of expelling racialized peoples from the nation, see Goldberg, Racist Culture, pp.81, 98, 137.

78. Sunahara uses this term in The Politics of Racism to describe the specific events of 1946 and the pressure exerted by the government to force people to leave the camps at that time. She is not alone in the use of this term to describe the process of leaving the camps.

79. Canada, BCSC, Removal, p.2.

80. See, Sunahara, The Politics of Racism, especially pp.66-70. See also Takeo Ujo Nakano's account of being incarcerated at the Angler POW camp in Within the Barbed Wire Fence (Halifax: Formac, 1983) and Robert K. Okazaki's, The Nisei Mass

Evacuation Group and P.O.W. Camp '101', translated by Jean M. Okazaki and Curtis T. Okazaki (Scarborough, On: n.p., 1996).

81. See for example, Sunahara's description of the NMEG in The Politics of Racism, pp.67-71, and Roy Miki's description in Broken Entries (Toronto: Mercury Press, 1998), pp.19-20, 190-191.

82. Nunoda, "A Community in Transition," p.98. Note that Nunoda uses the term "evacuation" uncritically. 
83. For a description of Tanaka-Goto see, Midge Ayukawa, "Good Wives and Wise Mothers," B.C. Studies, 105-106 (Spring/Summer 1995): 116.

84. Foucault quoted in Yeğenoğlu, Colonial Fantasies, p.61.

85. According to Sunahara, 296 Issei men and 470 Nisei men were interned in prisonerof-war camps. See, The Politics of Racism, p.70.

86. Sunahara, The Politics of Racism, p.66.

87. Adachi, The Enemy That Never Was, p.232.

88. Sunahara, The Politics of Racism, pp.59, 65-76.

89. Canada, Department of Labour, Administration, p.5. See also Yoshiko's comments about the men who left Slocan to work in logging camps and returned on the weekends, Chapter Five.

90. The Canadian-born "males" were listed as numbering 3,590 and the "women and children" as 2,994. NA, RG 36/27, vol.1, file "Distribution of Japanese." "Memorandum Covering Japanese Movement Pacific Coast," 18 July 1942.

91. Canada, Department of Labour, Administration, p.5.

92. Sunahara, The Politics of Racism, p.55.

93. Canada, BCSC, Removal, p.8.

94. Ibid., emphasis added.

95. Yeğenoğlu, Colonial Fantasies, p.94.

96. Ibid.

97. Interview with Kazuko, pp.13, 33.

98. Interview with Haru, pp.42-43.

99. Sunahara, The Politics of Racism, p.57.

100. See Lisa Lowe, Immigrant Acts, p.11, for her tracing of how Asian masculinity was defined as "different" than Anglo- and Euro-American white masculinity, and also David L. Eng's interpretation of Lowe in extending this definition to an exclusion from "normative heterosexuality" in "Out Here and Over There," Social Text 52/53, 15, 3 and 4 (Fall/Winter 1997): 40

101. Interview with May, p.32.

102. Ibid., p.33. 
103. Canada, BCSC, Removal, p.8.

104. Kitagawa, This is My Own, p.116.

105. Ibid.

106. Ibid.

107. La Violette, The Canadian Japanese, p.65.

108. Ibid., p.67.

109. Ibid., footnote 23, p.65. 


\section{Chapter Five \\ EN-GENDERING THE SUBJECTS OF THE INTERNMENT: \\ The B.C. Interior Prison CampS}

\section{Introduction}

This chapter continues the arguments begun in Chapter Three that the spaces of incarceration, displacement, and forced labour were also spaces where Japanese Canadians experienced violence. In this chapter I will continue to utilize the testimonies from the eleven women who were incarcerated to demonstrate how the spatial differentiations enacted through the Internment produced violent ruptures in families, relationships, and communities. I will focus in this chapter on the "in-between spaces" of transportation to the prison camps and the spaces of the British Columbia interior prison camps. I will also argue that white bourgeois notions of gender both produced and were produced through the spaces of incarceration and displacement.

I will present this argument in the following way. I will argue for the necessity of seeing Japanese Canadians as heterogeneous subjects whose lived experience of the violence was differentially and relationally produced in the various sites of incarceration and displacement. I will continue to demonstrate how this violence was masked through various discursive moves on the part of the government and non-Japanese Canadian participants in the Internment process. I will also show how gender was part of an interlocking system of domination and was critical to the production of the various sites of incarceration and the enactment of the displacements. Finally, I will illustrate how this violence was materialized in the various sites of incarceration and displacement, and how women re-member these spaces of exile.

\section{Interlocking Systems of Domination}

Although much information was garnered from my interviews with the eleven women, this chapter will focus upon their descriptions of the spaces of the interior prison camps. Chapter Six will examine the spatial descriptions of the so-called Self-Support communities, the Sugar Beet forced labour projects, and the spaces of domestic service. Each site of incarceration and displacement presented different spatial arrangements and 
different encounters with white people. I will indicate how the women's representations of the violence produced through these spaces negotiate and contest predominant discourses of the Internment. Chapters Four to Seven, therefore, emphasize that we must understand the particularities and complexities confronted in each space of incarceration. Who inhabited each space and the spatially-specific social processes occurring there also influence the production of memories of that site. A spatial analysis of the Internment can therefore be used to contest historical representations that obfuscate the violence of the Internment through its narration as a uniform and singular experience.

Throughout these chapters I will argue for the necessity of conceptualizing gender as part of an interlocking system of domination. This interlocking insinuates power relations in a complex way producing different effects and hierarchies of relational subject positions. Sherene Razack provides us with an analytical approach to understanding how systems of domination interlock in constructing hierarchies of gender and race. This methodology differs from that which emphasizes intersectionality. As she states, "Interlocking systems need one another, and in tracing the complex ways in which they help to secure one another, we learn how women are produced into positions that exist symbiotically but hierarchically."1

While my work cannot accomplish an in-depth analysis of the interrelationships amongst these spaces of incarceration, I offer a preliminary illustration of how I use the theory of interlocking systems to understand how the spaces of incarceration were produced and hence produced different subjectivities. What is contributory to the destabilizing, fragmented process of the Internment and is in fact emblematic of it is its dependence upon the mobilization of interlocking systems of domination. This analytical framework is critical to understanding the Internment's relationship to nation-building and my work seeks to make a contribution in illuminating this understanding.

What I also wish to underline in this chapter is the complex construction and masking of the violence, while at the same time emphasizing that the enormity of this national violence can never be exhaustively re-membered nor "known". I hope to trace how nation gets constructed through these elisions and discursive constructions and how women negotiate their rememberings in relation to nation. I will continue to investigate the interrelationships between the spaces of Internment, the social processes produced 
through these spaces, and the effects of these processes upon the ability to remember and name the violence produced through these complex social arrangements. It is this difficult process of re-membering our own social locations, forged through domination and subordination in the Canadian nation state, that I offer as a challenge to all readers as we witness these fragments of testimonies.

\section{Heterogeneous Subjects}

Each person that went through the war years has their own experience so, you know, they could write their own experience.

Aya $^{2}$

Women re-member the sites of Internment and displacement differently and their memories illustrate that heterogeneous subjectivities were produced in relation to the violence inherent in these multiple geographical ruptures. The purpose in demonstrating heterogeneity is not to promulgate the simplistic "adding women's voices" notion current in some feminist methodologies. That is, I do not wish to promote the notion that the Internment was a heterogeneously experienced violence through an argument positing that women are socially constructed unitarily in opposition to men. Gender domination is clearly more complex than this dichotomization. Rather, I seek to show that it is only through recognizing the heterogeneity materialized through the interlocking of race, gender, class, sexuality, age, and physical ability that one can attempt to understand the complexity of the construction of oppression and the necessary strategies to contest it. It is how each system of domination enables others to materialize in particular ways that is my methodological tool for understanding the construction of the sites of Internment and the particularized violence produced for each subject in and through these sites.

Audrey Kobayashi is one of very few writers in the Japanese Canadian historical literature who explicitly addresses gender as an operational category of subordination. In addition to her significant scholarship in the area of the Internment, her work on gender analysis in relation to Japanese Canadian women has been pathbreaking.

Kobayashi argues that "race" and "gender" differences were "taken-for-granted facts in the 1940s." As she states, "It was 'natural' to think that women and 'orientals' should not be considered to have the same rights as white men, and the law reflected this 
attitude both implicitly and explicitly." 3 She further argues that Asian women were given little attention by the Canadian state and "their fates follow those of their husbands and fathers." While I agree with Kobayashi that the government positioned Asians and women as subordinate to white men prior to and during the 1940 s, my work attempts to demonstrate how the state mobilized race and gender discourses through the violence of incarceration, forced labour, and dispersal. I hope to illustrate how gender was a critical component in spatially separating Japanese Canadians and how it is through discursive interlockings of systems of domination that the Internment was accomplished. It is imperative to contest a static, essentialized notion of gender and illustrate how male domination is continually reinscribed and contested through different processes. In particular, my work interrogates the inclination to see Japanese Canadian women only within a patriarchal relationship of stasis with "Japanese" men and points out ways in which the Canadian state utilized white hegemonic discourses of en-gendering, materializing gender differences through the violence of the Internment, gender differences that enable particular notions of masculinity. My research also emphasizes that there are differentiations in the ways in which gender is conceptualized for white bourgeois women and for Japanese Canadian women. It is through an examination of these interlocking processes that I wish to underline how these acts of violent exclusion were also interpellating mechanisms of both en-gendering and racialization.

As was argued in Chapter One, interventions into a national narrative silent on the Internment produced the social conditions for the ground-breaking works of Ken Adachi and Ann Gomer Sunahara. These interventions made the case that the nation's citizens largely accepted and promoted Japanese Canadians as an undifferentiated and foreign group in its execution of the expulsion and Internment. In arguing against the rationalizations promulgated by this expulsion and exposing them as racially motivated acts, Adachi and Sunahara, through their meticulous research and writing, presented more unitary subjects. They could little afford to illustrate the heterogeneity amongst Japanese Canadians and their experiences of the Internment given a context where this historical trauma was forgotten and thus denied in the narratives of nation.

In writing against the forgetting of racialized violence, the paradox for scholars advocating for communities of colour has been that we have also used this category of 
our "racial" unity and sometimes subscribed to the position that racism is the primary cause of oppression. The risks in showing heterogeneity - for example, class and gender divisions - are many given the selective memory practices mobilized through narratives of nation. Ilustrating how hierarchies of gender and class are constructed within a racialized community can be misused to minimize or deny a recognition of the violence done through spatial segregation and displacement. This is often achieved through redemptive narratives focusing upon individualized attainments of class and/or gendered and/or heterosexual and/or ableist privilege (often under the generalized rubric of "freedom") "after" the emblematized "wrong" has occurred. It is also accomplished through situating the processes of producing hierarchization and violence solely within the racialized community; for example, when it is argued that male domination within the Japanese Canadian community is achieved only in relation to Japanese Canadian women, there is an obfuscation of the hegemonic power and violence of white bourgeois masculinity in the construction of the Internment.

My work attempts not to dispute Adachi's and Sunahara's analysis that racism was operational in the construction of the Internment but hopes to achieve a more complex understanding of how social relations of domination, including racism, interlocked in the accomplishment of violence. It is clear that race was the entry point for the wholesale expulsion and dispossession of Japanese Canadians in the 1940s. What I seek to also clarify is how this violence was multiply articulated through other systems of social domination and how these interlocking systems were lived by the subjects expelled.

I know that I am able to attempt this analysis because of the work of Adachi and Sunahara, building upon their analyses by drawing from the work of many thinkers who have articulated how social oppression is enacted in multiple ways. As Lisa Lowe states: "In the 1990s, we can afford to rethink the notion of racialized ethnic identity in terms of differences of national origin, class, gender, and sexuality rather than presuming similarities and making the erasure of particularity the basis of unity." statement underlines the possibilities of contesting domination from multiple social locations, we must still be critical of the notion of a "progressing" milieu of the $1990 \mathrm{~s}$ and be ever cognizant that complicating a seemingly unitary site of domination may be 
taken up in problematic ways by the political right, for example, leading to a relativist analysis denying the harm of particular forms of oppression. My argument for demonstrating the heterogeneity of subjects of the Internment is to counter that denial through understanding how various subjects get positioned in different ways to produce a complicated picture of violence. It also aims to illustrate who benefits from this complex imbrication of social domination and subordination.

\section{In Between Spaces/Transportation to the Sites of Incarceration and Forced Labour}

The in-between spaces - the spaces in which one was transported from one carceral site to another - are difficult to imagine. The anxiety of not knowing where one was going or what lay in wait must have been enormous. Many women had to travel alone with children, separated from the support of friends and partners. This too is part of the gendered violence they experienced. S., whose family was moved three times before they were finally moved to Toronto, described how they were transported from their home in Vancouver to Tashme:

MO: What year did you actually have to leave Vancouver? S: 1942. And it was late in the year, I think. We were later. MO: And how did you travel?

S: By train. We went by train and then by truck. Tashme was fourteen miles from Hope, so we travelled by truck. And that was a very primitive way of getting up there. But it was a very primitive place, too, that we were going to live in, so. It was quite an experience. ${ }^{6}$

Evelyn describes how, as a child, she had to rely on what was told to her by the adults. She states, "The news filtered down to us, as kids. So they may have known things that we were not told."7 She learned that "people were going to this place and this place" but it "didn't make sense to us."8 She first learned people were being moved to Hastings Park in hearing that "people were coming in from all over the place to Vancouver to [the] Park." Her association with the space of the "Park" was that it was used for fairs and she remembers asking, "What are they doing there? Is the [exhibition] in town?"10 She was told that "people were being moved out." She describes what she did with this information: 
We used to run down to the railroad; right behind the Japanese Language

School were the rails. So we used to run down there and wave at people going out to Greenwood or wherever they were going. ${ }^{12}$

From her child's purview, Evelyn reveals what she did with the information that people were being "moved out." She also provides the devastating detail that the people being moved via Vancouver had to pass through the Powell Street area, the home space for many removed and the heart of the Vancouver Japanese Canadian community.

When I asked Margaret how she and her family were moved from Vancouver to a prairie sugar beet farm, she emphasizes that she was only twelve at the time. She states. "it didn't really affect us the way it did our parents. Because our parents had to leave everything behind and go to, god knows where. Whereas for [the children], it's great. we're going on a train. We're going across Canada. Isn't that exciting." ${ }^{13}$ Later in the interview, however, Margaret re-members being on the train that took her to Manitoba:

I don't even like to think of that train trip cause it took four or five days to come from Vancouver to Winnipeg. And it's cramped quarters, I mean there's nowhere you could lie down. You had to sit up on those cane seats all the way for four days. That was really, I thought it was really hard. And it was in the summer, we came, so it was really hot and uncomfortable. ${ }^{14}$

\section{The Interior Prison Camps}

Rosebery, Tashme, Slocan, New Denver

Eight of the women I interviewed were forced to move to the B.C. interior prison camps. May, Yoshiko, and Ann were incarcerated in Slocan City. S. was incarcerated in Tashme and New Denver. Kazuko was incarcerated in Rosebery. Aya and her daughter, Louise, were incarcerated in Greenwood, Tashme, and they were later moved to Manitoba. Haru has requested that I not name the camp in which she was forced to live. I did not interview women who were forced to live in the Sandon; Kaslo; and Lemon Creek, Bay Farm, and Popoff (all referred to as part of the "Slocan" valley area) prison camp sites. I did, however, interview women who lived in the "Slocan City" incarceration site, also referred to as "Slocan." References to New Denver are also sparse as the woman who had been moved there had also been incarcerated in Tashme and the latter was the focus of our discussion. It is also critical to note that I did not interview anyone who was deported to Japan prior to or after the Repatriation Survey was conducted. 
In this section where I look at some of the ways the prison camp sites were en-gendered for women, I underline that much more work is needed to cartographize these spaces. Each site had its particular geography and this geography allowed for certain activities. What activities were undertaken in each site is a subject deserving of much more attention than I am able to devote in this thesis.

\section{Greenwood and Tashme}

Aya, who was twenty-three when she was forced to leave her home in Steveston, was moved five times before finally moving to the prairie city where she currently resides. She and her children were moved four times between 1942 and 1946. She was born in Steveston, a predominantly Japanese Canadian community, and had lived there all of her life until the expulsion. Up to that time, all of her friends had been Japanese Canadian. She was pregnant when she and her children were forced to move to Greenwood.

MO: How old were you when the war started?

AYA: Oh, I was quite young yet. Let's see, about twenty-five or twentysix.

MO: So were you married by then?

AYA: Oh yes, I was married. And I had my two eldest daughters and my son was still a baby when we had to evacuate from Steveston.... But the men couldn't go because they all, you know, went to road camps. And so I left my husband who went to Hastings Park and then with my kids and with the neighbours we all went to Greenwood.... I hadn't heard from my husband for quite a long time, over two months after I went to Greenwood. And I was wondering what happened to him.... And then I finally got a letter from him, from the internment camp. Angler. I wasn't too sure why he was sent there. And after the war, when we got together, he told me.... So we were separated four years. So we both had a hard time."15

Aya was also separated from her mother and brothers who were sent to Manitoba to work on a sugar beet farm.

Two of the women I interviewed, Ann and Aya, had children at the time of the expulsion from their homes on the west coast. At the time of their interviews, Ann was 82 and Aya was 77. They both bore children while in the prison camps. How the space of the prison camps was embodied for generations to come cannot be more clearly illustrated than by those women who gave birth to children in the sites of incarceration and 
displacement. This embodiment is a profoundly gendered one. Experiencing the pain of labour in such a setting, removed from communal and extended familial supports, is a violence that disappears in a collective forgetting of the people who inhabited those spaces of imprisonment. And for those who trace their places of birth and those of family members back to these sites, there is the constant contestation of the normalcy of these birth place names in a nation that forgets their other meanings.

Aya was pregnant with her fourth child when she was separated from her husband and sent to Greenwood. She described how she was the first woman to have a baby in Greerwood: "I was the first one to have a baby in Greenwood...I was in the hospital for six days, so they sent two girls to look after my kids." ${ }^{16}$ When I interviewed Louise. Aya's daughter, she described what she remembered of her mother giving birth. She was three years old when they were moved to Greenwood: "My younger sister was born there...I remember when my mother was in the hospital, a couple of nuns would come by. I don't know if someone in the apartment looked after us but I just remember the nuns coming to wash us up and everything else."17 Louise had also described to me that when she was living in Steveston, her grandmother had cared for her and her siblings while her mother worked at the cannery. Her grandmother, however, was far away on a sugar beet f.urm while they were in Greenwood.

In a government report, Greenwood was described as a "once prosperous mining town," "nine miles north of the international boundary in central British Columbia." 1942, 1,777 Japanese Canadians were forced to move to Greenwood. There was a "white population" of 150 at that time.

The Greenwood prison camp seemed unique in that there was a substantial population of people who had been moved from one geographical community Steveston - to this prison site. Some of Aya's neighbours and friends, therefore, were also imprisoned in the Greenwood site. Yet after two years in Greenwood, Aya was forced to leave them and move again. She explains the reason she was given for this move:

And then after two years the Security Commission, they called it.... Well they informed us that they wouldn't have internees' families - they called us internees' families because our husbands were interned - in 
Greenwood. So they sent us to Tashme. And I was there until the war ended. ${ }^{19}$

Thus even within the prison camps, notions of "difference" were imposed, creating different categories of inmates.

Aya's daughter, Louise, was three when they were moved to Greenwood. She explained to me that she has "happy memories" of the Internment because she was "so young and didn't understand anything... you ask questions and that but you don't hear the sadness or what [my parents] had to go through." ${ }^{20}$ In Greenwood, she remembers sharing one room with her mother and her three siblings. The women cooked and fed their families in a communal kitchen downstairs. She also remembers being cared for by other women in Greenwood, for example, in the communal women's bath to which she and her sister would sometimes go without their mother. She states, "there were always women in there taking baths who would help us. They would either wash our faces or scrub our backs. They would always be there to help."21

Caring for children in these desolate environs must have posed numerous problems for women. Despite Louise's comment that her's are "happy memories," she also alludes to what must have been the hardships for her mother. For example, she tells me that her younger brother nearly drowned and she states that her mother "must have had it very, very rough with four young kids and being by herself." 22 Her mother did all of the sewing of their clothing and although Louise does not remember being able to take any toys with her to Greenwood, she remembers her mother took her sewing machine and her trunk, which was packed with all their "life things." Louise states, "I remember the old sewing machine and this trunk. And to this day, she still has the two of them."23 Later in the interview Louise tells me, "[my mother] still has her wedding gown and the wedding pictures...they were all in that trunk that she insisted be brought with her every time we moved." 24

When I asked Louise about her father, she put his absence within the context of who else was "missing" from the Greenwood and Tashme sites. She told me that the grandmother, who had cared for her when they had lived in Steveston, now had to resort to sending "care" packages from the sugar beet farm to which she had been sent. It is obvious from Louise's testimony that her mother tried to maintain communication with 
her husband and mother. She states that her mother would tell them where her father was and how he was doing but she also reveals the impact that her father being removed had on her:

[My father] spent the rest of the war years in Angler. So my mom was left with the four kids in Greenwood...I can't even remember my father before that. After he left, the memory of him was sort of erased. All we saw were his pictures. We didn't know where he was. He was gone, he wasn't with us right there. ${ }^{25}$

Louise's memories of the prison camp space also gives a glimpse as to how children's lives were gendered and how these practices of en-gendering continued to be linked to nation. When I asked her whether any activities were organized for children in Tashme, she replied not for children of her age. However she remembered the older boys playing baseball and having boy scout rallies. She described how the boy scouts would hold a jamboree once a year. ${ }^{26}$

Much more work is needed in analyzing how these practices of en-gendering continued in the various sites of incarceration and displacement and their connection to the formation of national subjects. The Tashme boy scout troop was organized by Shige Yoshida and included over 200 members before the prison camp was finally closed. This troop was the largest in the British Commonwealth during this period. Catherine Lang describes Yoshida's effort as offering the boys "a bridge to the white man's world, a way of installing pride in themselves and a means of demonstrating loyalty to king and country."27 I would argue that through the dominant discourses of masculinity practised through sports, such as baseball, and through activities such as scouting and the "national" event of a jamboree, boys and men were able to constitute themselves as belonging to a certain nation space at the same time as they were excluded by this nation within the space of the prison camps. Whether this activity of claiming entitlement to the nation space is that of resistance or aspiring to domination is an important question for further investigation. What is critical here is how discursive processes, such as gendering, were structured relationally in the different sites of incarceration.

Louise also remembered that in Greenwood, she first encountered the Catholic church and having to "cross herself" in it. The nuns, including those who took care of her and her siblings when her mother was giving birth, were white women. When they were 
moved to Tashme, Louise mentions she remembers a United church in that site. Louise's comments emphasize how the prison camps were sites associated with specific Christian affiliations. ${ }^{28}$ Kindergarten and high school students in the camps, in particular, were dependent upon the churches to educate them as the provincial and federal governments refused to pay for pre-school and secondary education. The influence of the white missionaries and conscientious objectors who taught in the camps is a topic for further investigation. ${ }^{29}$ Their direct contact with Japanese Canadians in the prison camps had a lasting impact upon how the Internment is re-membered. I would argue that this contact also complicated the ability to see the extent of the violence in the different sites of incarceration and that Christianity was a significant discourse in the production of particularized notions of the Canadian nation.

Louise also pointed out to me that the superintendents of the schools in Tashme were "the whites." 30 Yet her teachers were "all Japanese." 31 She also remembers the white Royal Canadian Mounted Police (RCMP) had a station in Tashme and the "whites" lived across the river in a "separate area by themselves." 32 Thus there was a consciousness, even at her young age, that racial hierarchies existed within the prison camp system and that these hierarchies were spatialized.

A government report emphasized how Tashme was named by using the "first two letters of the surnames of each of the three commissioners of the British Columbia Security Commission" (see Chapter Three). The report continues by describing this prison camp site as "situated on a ranch...leased for the duration of the war," " 14 miles south-east of the village of Hope...situated on the scenic Cariboo highway, a beautiful three hours drive from the city of Vancouver." The road from Hope to Tashme was but a "rough, narrow mountain trail," and, as the report suggests, became a site of work for Japanese Canadians forced to upgrade it to become "part of the Hope-Princeton Highway." 33 Despite the government's travelogue description, Tashme was clearly a carceral site. The report was ominously clear in the purpose of the Tashme site: "the valley in which Tashme nestles is about one mile wide and about 15 miles long, surrounded by precipitous mountain slopes closing in at each end into very narrow and easily guarded entrances. A better place could hardly have been found to house a large number of Japanese evacuees." 34 
As Tashme and its buildings were constructed solely for the purpose of incarcerating Japanese Canadians, there were very few white people living in the area other than those who were sent there as part of the Internment scheme. The fact that the government report does not even list white residents in the area is an indication that there were few white people living in the Tashme environs. In 1942, 2,636 Japanese Canadians were forced to move to the Tashme prison camp.

As in the case of May, S. lived in a white area of Vancouver before she was moved to Tashme. She was approximately 12 years old when she was moved and she refers to Tashme as one of the places that "wasn't a ghost town." 35 After four years in Tashme, she was moved to New Denver, and in 1948, three years after the end of the war with Japan, she was moved to Toronto.

S. remembers that some of their hakujin Vancouver friends visited them while they were in Tashme. Upon their second visit, they were stopped at the entrance by the Mounties and forbidden entry. She explains, "anybody coming in or going out would have to stop there at the Mounties' office. ${ }^{36}$ She also indicates how white officials monitored and delineated the boundary between Tashme and the "outside world" 37 and that this authoritative whiteness was a dominant presence in the prison site, "you couldn't come into Tashme unless you went past the Mounties' office. So you would see them all the time." ${ }^{38} \mathrm{~S}$. describes this failed visit by her friends as a "reminder that we were, what do you call it, not in prison, but there was a control factor there." 39

Ken Adachi attempted to deal with the issue of what to call the interior camps by writing:

these camps came to be labelled by government administrators as "interior housing centres," "relocation centres" or "interior settlements." But these almost reassuring descriptive terms... were simply euphemisms for what many Nisei and others preferred to call "internment" or "concentration camps."... To call them "concentration camps," however, after the pattern of Dachau or Treblinka or even the ten camps in the United States, or to label them "prison camps" after the pattern of prisoner-of-war camps in Europe or Asia would be a gross exaggeration... what all the official euphemisms glossed over was the inescapable fact that the evacuees were being held involuntarily. ${ }^{40}$

Adachi poses the problem of how to name what is unnameable within the context of Canada. His semantic analysis is very specific to space and the space of nation and 
suggests that one cannot easily adopt words connected to other historically-specific atrocities to describe the processes of expelling, incarcerating, and displacing Japanese Canadians. What is important to consider, however, is whether the space of the Canadian nation is one where atrocities can ever be fully named and how the upholding of the notion that Canada's atrocities are lesser than those committed by what are portrayed as less "civilized" countries serves to deny the violence occurring in Canada." This semantic forgetting also occludes Canada's discursive dependence upon maintaining other countries as pathologized spaces and our material participation in their economic and political status.

A government report lauded the efforts of the RCMP in maintaining the "security" of the prison camps. It states, "The settlements are situated in mountainous valleys from which the only outlets are by a few roads. On these roads the Royal Canadian Mounted Police established road blocks at which special guards check all passersby." ${ }^{22}$ Although people may contest the naming of the means of confining Japanese Canadians, there is no doubt that the state ensured their imprisonment.

S.'s struggle to name the spatial confinement of Tashme reflects the semantic legacy of the Internment. It was "not a prison" in the sense of what she knew and it is this spatial differentiation that the government used to define it as "not internment" and the prison camps as "not concentration camps." What is also clear in S.'s description of Tashme is how the discourses of Internment are necessarily constructed relationally by comparing one's own situation to that of others who experience violence. What is apparent here is also the poverty of language and the care that is taken in making semantic differentiations acknowledging the specificity of the sites of exclusions. What is troubling to me is when survivors' struggles to contextually name their experiences as "not" that which conforms to a commonsense notion of a particular space or experience (for example, not "prison") are interpreted as acceptance or passivity in the face of that undefinable violence.

S. continued in her interview by telling me that other white people visited them from Vancouver and the Okanagan. She describes these visits and her letter writing as keeping "in touch with the outside world."43 Thus the space of Tashme is clearly defined as a separate and insular site removed from the space "outside" inhabited by white 
people. At times the white visitors were allowed to enter the confines of Tashme and yet even in the moments of their being denied entry, they were always allowed to return to the "outside world." What is important to note is how the "inside" of Tashme was actually connected to the "outside" in the making of that "outside." In other words. the racialized space of the camps and the denial that they were prisons has been a necessary process in the making of white bourgeois subjects. And of course, for these white "visitors" what constituted the "outside" for S. was actually their "inside." The relegation of pathologized spaces, such as reserves and the Internment prison camps, to the separated exteriority of white bourgeois existence is necessary to their construction of self as "respectable," and obscuring this dependent relationship also secures the notion of their selves as autonomous. What would be of further interest would be examining how the white subjects who visited and worked in those sites of incarceration constituted themselves in relation to them. I would argue that the process of "visiting" these sites (as extraordinary as these acts seem to me) are exemplary moments of whiteness being reconstituted through violence.

While she admits there may have been a lot happening in the prison camp of which she was unaware, what $\mathbf{S}$. knew conveys a profound sense of hardship. She describes the house they shared with another family as having "single walls, covered with tarpaper." "Summers were extremely hot and the winters were extremely cold." ${ }^{45}$ At an altitude of 2,410 feet, the temperatures in Tashme ranged from 95 degrees Fahrenheit in summer to as low as minus ten degrees in winter. ${ }^{46}$ Water taps were outside of the houses and people filled pails with water and carried them into the houses. She also emphasized that "people survived in these conditions," 47 thus alluding to the fact that the conditions challenged one's ability to survive.

S.'s two sisters worked while they were in Tashme and her brother worked in a sawmill and returned only on the weekends. Given her age at the time of the Internment, S. felt the impact greatly upon her education. She missed one half year of schooling due to the length of time it took to organize classes. She also reported how Japanese Canadian teachers would be transferred to other prison camps and how male Japanese Canadian teachers, in particular, would disappear overnight. She explains: 
we started out with some teachers and they vanished overnight...the single men were not allowed to stay in the ghost towns. If they were over eighteen, they were supposed to be in camp or elsewhere and I think they all moved east or something happened. But we lost the teachers that we started out with and we had different teachers from then on. ${ }^{48}$

S. managed to complete grade seven in a few months and was able to enter grade eight. She was aware of how differentiations between Japanese Canadian students and white students were ongoing in her comment that her brother, who due to the lack of provision of high school classes until much later, took high school courses by correspondence and had to pay, "about three or four times the amount that was paid by others." ${ }^{\text {"99 }}$ When S. began high school in Tashme, classroom space in the camp was at a premium and she had to go to school six evenings per week from 4 p.m. to 6 p.m. and 7 p.m. to 9 p.m.

S. was moved to New Denver in 1946 because her family had agreed to move east in response to the Repatriation Survey. She describes how they had to leave Tashme "because people came from the other ghost towns... who were going to go back to Japan were gathered together in Tashme." ${ }^{50}$ When S. describes her move to New Denver in 1946, she also tells me that members of her family had already been separated - her sister and brother had been moved to Ontario and her other brother was living near Kamloops, B.C. It is important to note that the displacement of S. took place after the end of the war with Japan, yet the incarceration in the prison camps continued years beyond armistice. It was not until 1948 that S. was moved to Ontario. Displacement was and continued to be a far-reaching process across time and geographical space.

While my work does not address the different ways in which people organized in each incarceration site to protest conditions or government regulations, it is clear from each woman's testimony that the relations of power were struggled over in each space of incarceration. I situate these struggles as resisting power in the Foucauldian sense and I am uneasy with attempts to hierarchize acts of "resistance," especially when only certain kinds of activities are hailed as the best or only examples. As I witnessed women's memories of their activities within the spaces of incarceration and found women's correspondence in the National Archives, I began to understand how resistance and our notion of resistance are also informed by hierarchical hegemonies. For example, a woman 
who is pregnant and/or caring for children has different constraints placed upon her abilities to act as compared to a man without these responsibilities. Not being incarcerated, as was the case for Muriel Kitagawa who was given a permit to move to Toronto, placed a person in a different position than someone who was imprisoned in the prison camps. Space and the social relations produced through each space therefore come to bear on the enactment of activities. Space and the restrictions imposed therein also affect our abilities to see how people negotiated with the power imposed upon them and "resisted" the violence of incarceration.

As is clear from correspondence heid in the National Archives of Canada, many women and men wrote to the government to protest various elements of the government's policies. Letters in this repository can be categorized in two ways: one, those written directly to the government and two, those that were censored by the government. I will make use of letters from the former category in this thesis. The latter category - a record of the violence done to women, men, and children - comes to us as a result of the violence, the invasive practice of state censorship and the ways in which people's lives were subjected to scrutiny with extreme attention paid to minutiae. As compared to the letters written in 1942 by Kitagawa to her brother, the censored letters in the archives were never received intact by the addressees. ${ }^{5 !}$ It is only through the government's copies of the originals and their deletions that we have a record of what was originally written in this correspondence. Part of the legacy of the violence done to Japanese Canadians is this property still "held" by the Canadian government. Most of the addressees will never know of the contents of these censored letters in their entirety, while the public has access to the letters still in possession of the Canadian government. As earlier stated. dispossession did not begin or end with the confiscations put in place by the Custodian of Enemy Alien Property.

On 26 December 1942, a woman incarcerated in Tashme wrote to the Consul General of Spain in Montreal requesting that her husband be released from a prisoner-ofwar camp. ${ }^{52}$ In the letter, she outlines the steps she took in trying to secure the release of her husband and also outlines her own situation as a woman within the space of Tashme:

On the very moment when learning of [my husband's] apprehension...I consulted and requested...the Barrister of Vancouver, B.C., for his every 
effort in obtaining my husband's release, but his effort was futile. There were sixteen men in this group including my husband at the time of apprehension at Slocan, B.C. Later I learned that nine of these men have [been] released from the internment. Question is why not my husband also? I am a mother of three infant child... after breast operation, I am always in state of poor health. ${ }^{53}$

At least two letters were sent to the Spanish consulate from a woman in Tashme asking for her husband's release from a POW camp. On 4 May 1943, she wrote that she had three children, aged one, three, and four. She was suffering from neuralgia and she stated, "I feel uneasy for [my husband's] future life in Ontario and also my Tashme life without my husband." 54

In another letter, a woman wrote on 18 October 1944 that she had been separated from her husband since the early part of 1942. She had two children, eleven and twelve years of age. She was writing to request that her husband be released so that he might look for a job in Ontario. It was her hope that she might join him in Ontario and she expressed how she felt "discouraged and lonely." 55 Her concern for her children was articulated in her hope that in Ontario her children would "obtain a higher standard of education than what they are receiving here." 56 Two months later, the woman, who was very ill, again tried to secure the release of her husband and asked that he be sent to Tashme before she was hospitalized. On this occasion, she addressed her letter to the Minister of Justice, Louis St. Laurent. Her letter frames the ability to live as a family as a right of democracy and she argues that her children should have the right and the privilege of a "sound guardianship of their parents." 57 She adds, "in the name of democracy, I sincerely believe this may become true to them." 58

One woman in New Denver wrote to the Spanish Consul requesting the release of her son from a POW camp. In this letter, the woman reveals how she was responsible for taking care of her two children and her ailing husband, father-in-law and mother-in-law. Her father-in-law was bedridden due to paralysis. In requesting the release of her son, she states, "Sometimes I feel it is almost too much to look after the two children and my father and mother-in-law."59

While these letters are just a few of the many held by the National Archives of Canada, they are powerful reminders of how women contested the power imposed upon 
them, in this case the removal of their husbands to prisoner-of-war camps. It must also be pointed out that all of these women were Japanese Nationals and therefore "Issei," yet the image of Issei women's "resistance" is rarely depicted in representations of the Internment. In trying to care for their children, women struggled in many ways with the power imposed through spatial and social limitations. It is also not only through speech, however, that women negotiated the terms of violence; women, like Aya, for example took Japanese food staples with them to the camps as part of their poundage allotment. Aya also took her sewing machine so that she could make clothing for her children. While these acts by women become normalized and invisiblized as part of what women do to take care of children, I see them as ways in which they continued to resist the dehumanized conditions of incarceration. Surviving these conditions, as S. reminds us, were challenges to the body and spirit, and women who undertook the task of ensuring their children's survival in the camps demonstrate exemplary instances of contestation to the destructiveness of violence.

\section{Slocan}

A government report described Slocan City as an "abandoned mining town," "situated in the West Kootenays at the foot of Slocan Lake." 60 The area known by the government as "Slocan Extension" included the prison camps of Slocan City, Lemon Creek, Bay Farm, and Popoff. In 1942, there were 4,814 Japanese Canadians in the Slocan Extension prison sites. The report also described how Slocan was used as a "transfer point" for the New Denver, Rosebery, and Sandon prison camps. There were 350 "white people" in the Slocan and adjacent areas.

Yoshiko described to me how the Slocan prison camp left an indelible sense of racial hierarchies and how this was spatially constituted in that site of incarceration. She had grown up in the Powell Street area of Vancouver and was approximately three years old when she was moved to Slocan.

Yoshiko had little contact with white people in Vancouver. Her first re-membered experiences meeting white people were in the space of the Slocan prison camp. She remembers swimming in the "terribly dangerous" lake in Slocan and then warming herself by a fire that the older children would make after their swim. ${ }^{61}$ Despite her 
"wonderful" memories of being with other children and swimming, she also described to me how a "white guy would come around and tell us to put the fires out." 62 The white man wore "a straw fedora and a suit with a bow tie and he had a cane... He was officious but he must have been somebody official." 63 When I asked her how she remembers feeling when this happened she replied:

Oh god, that was terrible. It was like complete silence. Absolute silence. And I remember as he walked away, one of the older boys, you know, swore, muttered. When I look back on it now, it must have been really terrible, I mean as young people, to not be able to say anything, you know. And he was just a little man.... And he walked away so pompously. And, just a whole lot of resentment. I mean, terrific amount of resentment. Because he was white? I don't think so. It was because this guy told a bunch of kids to put out a fire. It was around the evening, dusk, so you're cold when you come out of the water. I mean it's ice cold water. So, you're always shivering around the fire, trying to get warm. And the guy says,"Put it out. Put it out." You know, of course, anybody's going to resent it. It just so happened he was white, so I mean you connect these things, you know, somewhere somehow. Subconsciously you connect it. So I' $m$ sure there was a lot of resentment from the older kids. I was just astounded. And I remember thinking, "Who the hell are you?" More angry than questioning because I was cold.... So, when you consider those are your first impressions. ${ }^{64}$

At one point, Yoshiko was taken to the Slocan hospital. She describes the hospital as being "at the very end of town in the area where the white people lived...I guess they were the police commissioners. I remember white people living there." ${ }^{65}$ She then told me another memory she had of being in the "white area" of the camp with a group of children younger than herself and they were confronted by a group of white children. She told me. "I can remember saying, "if you leave us alone, I'll give you a chocolate bar or give you something." 66 She then told the younger kids to run home after "fast-talking [her] way out of a situation." 67 The next day, this same group of white children came to look for her. She states, "I don't know where they got the nerve to come to our neighbourhood, but there they were at the bottom of the tenement building." ${ }^{\circ 8}$ With the support of Yoshiko's brothers and their friends, she was able to tell them to "go home." 69

Among the group of white children was a girl who was in Yoshiko's kindergarten class. She was the only white girl in their kindergarten class and Yoshiko remembers how she was chosen to play the role of Mary in their Christmas play. Yoshiko wanted to be 
Mary or an angel but had to play the part of a shepherd. She says that her mother has a photograph of the play's cast in her album and "there's Mary, the only white girl in the class...I often think about that." ${ }^{70}$ Thus, even within the racialized space of the prison camp, racial hierarchies had to be maintained and performed. The part of the woman of the nativity scene is assigned to the only white girl in the class. Not only were Japanese Canadian girls educated through the religious iconography proselytized through the camp schools and churches, but they were also given embodied enfigurations of racial hierarchies to which they were necessarily compared. The symbolism is interesting here: when "the" women's part is taken by white women, racialized women can be variously assigned roles usually assigned to men.

The white-dominated school space also marginalized the speaking of Japanese. Yoshiko, who spoke little English upon arriving in Slocan, remembers studying Japanese "secretly" in Slocan. She told me there was a sense of secrecy and illegality in speaking Japanese because she remembers "vividly" yelling out of the window of the Japaneselanguage classroom to another student to "hurry-up" and not be late for class. "She remembers she was "hit over the head with a pointer and told not to yell those things out the window."72 She attributes this reaction to the pressure the adults were under to speak English and she states,

Of course, a kid, which school are they going to want to go to? Go to these missionaries who are very kind and sweet and you sing songs and then this urgency to remember your language. The tension I'm sure that they were under. When you look back on it, it must have been really hard. I certainly was not that interested, which I really regret now. ${ }^{73}$

Yoshiko's father was removed from their family for two years and forced to work in a B.C. road camp. He was later allowed to join them in Slocan. Yoshiko describes how he worked for the Doukhobor storekeeper. When I asked her what other white people worked in the prison camp she listed the missionaries and the RCMP. She explains,

They were all people of authority, you know. To this day I still have problems with this authority business, you know, coming from white people. That's how I grew up. Everybody who had any authority were all white. And you didn't see them very often. Only when there were things to be done, things to be told, that kind of stuff. Except I must say the missionaries were very kind. But you just knew, you know, that they had more than you did. I mean, they were always the boss of things. You 
know, they led things.... That was my recollection of white people or my only contact with them. ${ }^{74}$

From Louise and Yoshiko's descriptions, we get a sense of the ways in which race and gender were mapped out spatially in the interior prison camps. White people, who appeared as enfigurations of discipline, "when there were things to be told," clearly inhabited different spaces even within the racialized space of the prison camp. The micro details of the ways in which Japanese Canadians were excluded were reflective of the ways in which the nation secured the white hierarchized spaces for its bourgeois subjects. Japanese Canadians were reminded of their tenuous position in the nation space and even within the space of the prison camp by the white people who lived in the area and by those who worked to maintain the sites of incarceration. One can hardly imagine the dailiness of fear and insecurity that these reminders of exclusion held for the inmates of these camps. Yoshiko's words strongly convey this sense of exclusion:

what happened in Slocan I think was just an indicator of what would happen in the future...I remember that time very vividly. You know. telling the little ones to go home fast and being really scared that this person who was the same age as me, I don't know what they were going to do to me...But the fact that this girl and her friends could say, "what are you doing here?" and had authority and the right to be there. I didn't feel as if I did have the right to be there at all and that I was invading somebody else's property and having to run home being scared. I don't know where that came from. But it was there and everybody accepted that. You know, it was just a part of that scenario. ${ }^{75}$

So despite what Yoshiko described early on as some memories of "good times" in Slocan, her testimony is rife with recollections of exclusion and pain. She was aware that her father was "very unhappy" while they were in Slocan. She also contextualizes her family's situation within a community that experienced the Internment in different ways. When she mentions her father's return to their family, she does so within the context of the other men who were "missing." She states, "A lot of other men were not with their families. Or a lot of them were working in the bush and coming back on weekends."76 She describes her interactions with adults as mainly with women because "there weren't too many men around all the time." ${ }^{77}$ She also states that her's was one family that did not go to Hastings Park but rather went straight from Vancouver to the Slocan prison camp. When she describes her own emergency visit to the Slocan hospital, she also remembers 
that one of her classmates was hospitalized and she thinks that she died. She remembers that "it was so scary" and the women were "weeping and wailing."78

Yoshiko also told me that the forced move to Slocan separated her family from her aunt who was white. She describes this relative as a "German" woman who was married to her father's uncle. She was also described as the only close contact her family had with a white person. Yoshiko's uncle died before the Internment. This is what she knew of what happened to her aunt and her children:

[My uncle's] family wasn't interned. The oldest son disappeared. He could pass as white. So he disappeared. And nobody knows where he went... The daughter was quite a wild one, according to my dad. She disappeared also..$^{79}$

A 1942 government report outlined the policy on people who were married to “Occidentals." Interestingly, the report focuses upon "Japanese women" married to white men and the children of "such mixed marriages," although there were also Japanese Canadian men who were married to white partners. ${ }^{80}$ Under the heading "Eurasians," the BCSC states that there were approximately one hundred such cases. ${ }^{81}$ On 11 April 1942, permits were issued to these individuals, "exempting them from all rules and regulations applicable to Japanese." The section of the report concludes: "The fact of their racial origin was to be disregarded and they were to be recognized as Canadians in the full sense of the word." 82

The exact number of children who were allowed to stay in the restricted area is difficult to deduce. A 1944 government report indicated that "fifty-two children of registered Eurasians and Intermarried Japanese who were listed on their father's record have been removed from our files, being of part-blood only." ${ }^{83}$ It added that these children were not "compelled" to register. Another reference to "blood" occurred in the same report, where two people were described as exempt from registration because they were "only quarter-blood Japanese."

In 1943, it was reported that there were seventy-four people who were "exempt from regulations in prohibited area," but does not supply the reason. ${ }^{84} \mathrm{~A}$ later report in August 1945 actually lists the category of "Intermarriage inside Area," and states the number to be twenty-eight. ${ }^{85}$ The October 1946 report gives the number as thirty. ${ }^{86}$ It is also clear that the "intermarriage" category included people married to other people of 
colour as was stated in a report that "one Japanese girl married a Canadian Born Chinese." ${ }^{87}$ It is also of note that at least one Japanese Canadian, gender unspecified, married a white partner during the Internment. A 1943 report described how an individual married an "Occidental" while in Lemon Creek and moved to Vancouver. ${ }^{88}$

The Canadian policy must be contrasted to that of the United States government in that Japanese Americans married to white people were incarcerated. Elena Tajima Creef examines the work of white artist Estelle Peck Ishigo who she describes as one of many "interracial spouses unwilling to break up their families, follow[ing] her husband Arthur Shigeharu Ishigo into relocation." ${ }^{89}$ Ishigo has become known through the art she created depicting life in the Heart Mountain intermment camp and through the book she has produced on her life in this camp. ${ }^{90}$ Creef observes that although Ishigo mentions that there were other white family members in Heart Mountain, no studies of the Internment have tabulated "the numbers of caucasians held in the camps who refused separation from Japanese and Japanese American family members."91

While more work must be done in analyzing the specifics of the policy of the Canadian federal government in its treatment of people who were married to nonJapanese Canadian partners and the children of these relationships, it is clear from government reports that "race" itself was a shifting category dependent upon different social discourses, mobilized to produce particular hierarchical notions of "Canadian" citizen and hence nation. But it must be reiterated: these categories are continually shifting and can be mobilized in different ways in the service of nation-building and domination. As we shall see in the next chapter, not all children of these relationships were allowed to stay in the coastal area. What I would also like to emphasize is that while people married to "Occidentals" appear to have been precluded from the official regulations applied to other Japanese Canadians and while this secured a particularized privilege in relation to those incarcerated, this discursive construction also resulted in violence for those Japanese Canadians not incarcerated. The multiple geographical and discursive separations imposed upon a community of interlinking family and friendship relations resulted in ruptures such as occurred in Yoshiko's family. How the nation "disappeared" these family members, separating them from those incarcerated and the 
incarcerated from them, is part of the violent process of these multiple and enforced separations.

Yoshiko describes how other women and her elder brothers took care of her in Slocan and how she felt "secure" that "everybody was looking after everybody else."92 She also remembers being bathed by women and children in the communal bathhouse. Yet while her testimony conveys how some people cared for each other, it also demonstrates her awareness of the tensions that imprisonment created for women. She remembers women arguing in the communal kitchen and states, "I think the people who had a hard time were the people who had to look after the kids in small, crowded apartments, having to share kitchen space."93

Yoshiko situates herself as the child she was with some "wonderful memories" of playing with other children in relation to this memory she has of leaving Slocan. She emphasizes that her's is a "kid's point of view." In this re-membering of people gathering together before they left Slocan, however, her evocation of the pain and the losses for herself and others is vividly apparent:

We had a big huge picnic in the ballpark. Windy, windy day. And over the p.a. they were playing, Auld Lang Syne. And when you play something over the p.a. on a windy day, you know, how the wind crackles it and everybody started crying.... It strikes me. I think it strikes me because it was such a sad, sad time.... And to this day I hear that song, and it's like, oh my god, it's not a happy song. I was just six but I can remember how sad everybody was. And everybody was just weeping. weeping. And the sound of that song over the p.a. that was crackling in the wind... it was so filled with pathos. ${ }^{95}$

May was the eldest daughter of a women-headed family when she was moved to Slocan at the age of fourteen. Like S., May grew up in a predominantly white area of Vancouver. Between 1942 and 1945, May was moved from Vancouver to Hastings Park, Slocan, and Toronto. Her mother and sister were additionally moved to New Denver after she left for Toronto. She describes the "evacuation" as a "difficult time" for her."

May felt the impact of the incarceration upon her education. She describes how she missed a year of school because the high schools were not set up. As she states, "The government did not think it necessary to build high schools." 97 Anxious to support her family, May applied to teach the elementary school children. She responded hopefully to 
a notice soliciting Japanese Canadians with at least grade ten to apply to teach. She emphasizes, "And I was fourteen!"98 She was encouraged by Hide Hyodo, who was involved in the hiring of teachers, to wait until high school classes became available. ${ }^{49}$ She went to the Anglican church-sponsored school because she was Protestant and she was taught at this school by missionaries. She reports that all of the missionaries in Slocan were women. Her mother, who had been raised as a Christian in Japan, encouraged her to join the United Church while they were in Slocan and she describes how she "had to walk up a road a considerable way because the United Church was up in Lemon Creek." 100

Unlike Louise who has good memories of bathing communally with the women of Tashme, May describes her experience in Slocan in this way:

I had trouble feeling at home in the ghost town. I really did. I took part in church plays and taught Sunday School. I had some good friends. But there are very few people from the camps that I stay in touch with. It was really culture shock to go there. It was difficult for me. The communal bathhouses, I never got used to that. ${ }^{101}$

In her description of a woman with whom they shared a shack in Slocan, we get a sense of their spatial restrictions and also how her life was lived in relation to the other occupants of that space:

We could not get a house with just three people. You had to have seven to eight people. The other family...had five people.... They eventually asked if they could put a partition down the middle and we would have our own stoves, rather than the communal kitchen in the middle and the bedroom on the side... we said you can move it farther over because you have more people. No, they cut it in half. And I used to have a terrible time lighting the fire in the morning... [The mother of that family] eventually would tiptoe over in the morning and make my fire for me. I know it doesn't sound like a lot but it was just a godsend.... She was a very, very kind person and I owe her a lot. ${ }^{102}$

May had a sense of the interminability of the Internment, how they were left in a prison camp with no idea how long they would be confined to that space. She states, "You have to understand that nobody knew when the war would end. It could have gone on for ages and ages." 103 She describes how they had felt the move from home would be temporary and it is this notion of the possibility of returning that co-existed with the trauma of homelessness and an indeterminate future. She states, "When you're in a camp 
like that and you've been moved out of your home and you think for awhile you'll be able to go back. We left things in a neighbour's attic, for goodness sake, thinking we'd be back." 104

In 1944, the United Church missionaries in Lemon Creek referred May to a "housegirl" job in Toronto. She departed from Slocan, leaving her mother and sister behind. Her mother and sister were later moved to New Denver, as had happened to S., after they agreed to move east through the Repatriation Survey. May describes this process of separating people in this way:

...the people who were going to stay here in Canada were shipped from

Slocan to New Denver.... They started to pool them together...they decided to have the one kind of people in one place and one kind of people in another place. ${ }^{105}$

Thus the prison camps continued to serve the purpose of spatially mapping and creating notions of gradations of disloyalty and loyalty, through the supposed "choice" of moving to Japan or moving "east of the Rockies," even after the end of the war with Japan. Despite the fact that she was moved to the space of those who would be tentatively allowed to remain in the Canadian nation, May's sister could only temporarily visit the spatially exclusive city of Vancouver, necessitating the travel between New Denver and Vancouver for four separate surgeries at the hospital.

Through these complex spatial displacements and exclusions, violence lived as multiple relational separations and the continual anxiety of not knowing what space one would inhabit in the future and with whom one would share that space was continually masked. The humanist notion of Japanese Canadians "choosing" these spaces and their dispiacements served to normalize this violence.

Ann was twenty-eight when she was moved to Hastings Park from Vancouver Island. Pregnant and with two small children, she was separated for six months from her husband in this site of incarceration. She was then sent to Slocan City and from this prison camp, she was sent to a hostel in southern Ontario, then moved to Chatham, and eventually moved to Toronto.

Housing was not ready when Ann, who was among one of the first groups to be removed, arrived in Slocan in February 1942. She was forced to live in a tent. The utilization of tents in the interior prison camps was referred to as the "erection of tent 
communities" in a government report; 1,000 U.S. Army tents were used and they measured sixteen feet by sixteen feet. ${ }^{106}$ Ann's husband had been moved to Tashme and she did not see him for six months. Ann was pregnant at this time and described the living conditions in this way:

We were living in tents and it was freezing then.... And then in the afternoon it got so hot that there was no place you could cool off.... You know, it's in the mountains, and when the sun comes over the mountain, it's hot and then it goes down quick and you freeze. Even in the summer. ${ }^{107}$

In Slocan City, the temperatures ranged from ninety degrees Fahrenheit in the summer to twenty degrees below zero in the winter with an average rainfall of ten inches. ${ }^{108}$ As in the case of S., the weather and the extremes of temperature in a mountainous clime, even in the time span of one day, are written on Ann's memory, the embodiment of the elements faced by her and her children with only a tent as shelter.

Ann remembers living in the tent for three or four months and then she had to move to a quarantined area of Slocan because her children contracted the measles. The body and its gendered relationship to space is vividly re-membered through Ann's testimony: her pregnancy and living in a tent, her children's illness and being moved to a separate area of the prison camp, her understanding of how hard it was for women to raise children in such spatial confinement.

While describing how she lived in quarantine with her two children, Ann states that their food was brought to them by the camp staff. Her daughter, Mayumi who was present for the interview, suddenly intervened and exclaimed, "Mom, you make it sound like a hotel."109

The understandings of these testimonies by children of survivors will be looked at more closely in Chapter Eight. What I wish to signal here is that survivors' accounts of attempting to create normalcy within a pathologized space are sometimes misconstrued as acceptance of that space or the violence done to them. As we have seen in the case of $S$., some people lived in the spaces of incarceration for seven years and longer. Within those spaces, heterogeneous subjects were produced. What has to date been little addressed in the literature and needs to be further enunciated is how people tried to reconstitute themselves, their families, and communities within these violent spaces, and how they 
worked to make these spaces more habitable. In the case of women caring for children, the challenges in negotiating the violence produced through these spaces (for example, separation from partners, families, friends, support systems, familiar food supplies, language, etc.) must have been enormous and were met with heterogeneous responses. For some, attempting to reconstitute what they could from their "memory of community" generated activities that seemed incongruous with the fact that they were being physically detained and meticulously policed. For example, Ann reports that some women gathered together once a week to share cooking knowledge, a kind of "cooking class." Women organizing in this way flew in the face of the government's claims that it was they who were teaching Japanese Canadians proper food principles. Ann also told me that she gardened. Gardening in the prison camps was a means of providing food for the family given the lack of food supplies and the little money with which to purchase them. It was also a way in which people attempted to deal with the violence of incarceration by creating health-supporting, aesthetically-pleasing elements in their everyday struggles to survive.

Men and boys, as we have seen and as Ann also confirms, worked together in scouts and in baseball leagues. At the same time, people organized at each site to protest the conditions and terms of their incarceration. What is complicated in the processes of Internment is that the government did not forbid the organizing of some of these activities. But it was at the initiation of the inmates, those excluded from the nation state. that these activities were materialized. And if we focus on these acts of reconstitution of subjectivity, initiated by Japanese Canadians themselves, without seeing the spaces in which they occurred, who and what was missing from those spaces, and what those spaces secured, the violence gets forgotten.

When Ann describes to me where she lived after she came out of isolation, she constructs her spatial situation in relation to others. She states that a shack housing two families was divided into three sections, each family inhabiting one room separated by a shared kitchen. She adds that she did not have to share with another family because by that time, she and her husband had three children and she was pregnant again, "I think those were the worst places. You know when you have kids. We were lucky, we had [a 
place] to ourselves. Plus it was right at the edge of [Slocan]. So there's no neighbours behind you or on the side of you." 110

Ann points out frequently in her interview that she feels other people suffered greater hardship. Early in her interview, she told me that her father was a veteran of World War I and this "past" fact is part of her re-membering of the Internment. When I asked her if there were mainly women and children in Slocan, she tells me: "Yes. And the men that were there were veterans of the World War I and that."1i' Her statement jogged my own memory, so focused was I on a "different" war," at times so chronologically driven I forgot how the present is ever so saturated with the meanings and material effects of the past. I remember that her father was a veteran of World War I and ask her what happened to her parents when she was moved to Slocan. Ann's daughter tells me her grandfather had died by this point. Ann responds by telling me her mother was "with the older group there. She had a sort of special...because she was a veteran's widow."113 The fact that her grandmother was also in the same prison camp as her mother was news to Ann's daughter. Ann describes how "Yes, she was in the same place as we were.... She had one room. They were lucky to have a room to themselves. And so were we to have a house to ourselves. Rather than share, the shared kitchens. I think that's the worse thing... and especially if you have children."114

Ann's testimony reinforces how divisions were created in the camps in various ways and how people had to deal with these seeming hierarchical arrangements within the context of everyone being incarcerated. Some people with four or more children were allowed to live in the pre-existing "ghost town" shacks without sharing this space. Her mother was allowed to live in one room to herself because she was a veteran's widow. And the one room becomes loaded with the weight of privilege in Ann's re-membering of the many who shared one-room spaces and her acknowledgment of the hardship of those who had children in them. But the horrendous implications of her mother's incarceration and all of the male veterans in Slocan, "loyal" World War I soldier families whose incarceration Ann re-members, are also witnessed in her words even as she attempts to minimize their traumatic effect.

Ann's critical comments, filled with a sense of irony, related her knowledge of relations of domination. When I asked her whether there was a store in Slocan, she 
responded by associating ownership of the Slocan store to a Doukhobor family who owned property in the area. She mentioned in particular a woman from that family whom she saw again "years later in Vancouver." Shaughnessy Heights, on "the better part of Dunbar." "I6 In this way, Ann emphasized that people profited from the incarceration of Japanese Canadians and that this profit went beyond a spatial and temporal notion of "World War II" producing future spatial and economic entitlements.

While it is important to recognize how Doukhobors as a group were marginalized within the Canadian nation - their very existence in the "ghost town" areas marked this spatial exclusion - it is necessary to also acknowledge the hierarchical arrangement of subordinated communities within these marginalized spaces and the Canadian nation, and that individual Doukhobor owners of property and commercial services profited from the Internment. Sunahara writes that the "Doukhobors helped by selling produce and other goods to the Japanese at lower prices than those charged by town merchants, $" 117$ and while this may have been the case, I would suggest that the intertelationship between these two marginalized communities was more complex than that of one "helping" the other. Ann's comment above points toward the necessity of a contrapuntal critique that analyzes how hierarchical relations are produced and observed even when they are forged in seemingly "inevitable" and conciliatory circumstances. I would also mention that Japanese Canadians had lesser or no contact during the Internment with the politicians or many other white Canadian citizens who also benefitted from their incarcerations. As Yoshiko's testimony suggests, "You didn't see them very often." Especially for the children and younger adults, contact with the white prison camp staff and administrators may have been minimal, except in cases such as described by Yoshiko when "there were things to be done, things to be told," and they were reprimanded and disciplined.

There may be other reasons for survivors not discussing the oppressive actions of the white people, both in the prison camps and outside of them. This would include the fact that Japanese Canadians were legislatively spatially restricted until April 1949 when the legal restrictions were lifted and they were allowed to return to the coast. They could not even see the material proof of their losses and those who now resided in, for example, their lost homes or lived on their property until this time. Some would never return to the 
space of British Columbia due to their treatment by its government and citizens. As earlier mentioned, it is also clear that the distantiated processes of the government bureaucracy ensured that Japanese Canadians would rarely, if ever, come face-to-face with any politician who made the decision to incarcerate them. Thus the white people most easily seen as profiting from the Internment would be those who actually inhabited the immediate spaces used for incarceration and who rented land to the government and sold services to it and the people incarcerated. These intracommunal relations would also explain more generally why different subordinated communities inhabiting pathologized spaces only target each other as the source of hierarchical power arrangements while even more powerful benefactors are safely distanced from the spaces of conflict. In the case of the Internment, the white people who moved to work in the sites of incarceration were spatially differently located than the white people who resided in those spaces prior to the Internment because the latter could leave these spaces. Also, the securing of whiteness and white nation enabled by the Internment is a less tangible product of these spatial exclusions and the ways in which Canada is continually produced and normalized as a white space in fact obscures the hierarchies upon which this hegemony depends.

Lawrence Langer has indicated that testimonies he examined from survivors of the Holocaust, "say little of their Nazi oppressors once the deportations have begun." 11 . He explains this within the context of the interview's demands on survivors to reconstruct the past through a knowledge of their present. For Langer, the interview presents the survivors with the "dilemma of their own identity," given the self that "endured atrocity" and the self that "sought reintegration into society after liberation." 119 Hence there is tremendous pressure placed upon survivors to present and "presently" negotiate their own identities rather than the identities of those who violated them.

Trauma is also part of this narrative and is always influencing the ways in which survivors can speak about the violence and those who instigated it. This realization that what is said about the white bourgeois subject or not said in Internment narratives is complexly reflective of the violence and the trauma inherent in that violence. This understanding may also inform our critique of why so little is actually written on how white subjectivities are constructed through this violence. As the gesture in Japanese Canadian studies (including my own) has been to "interview the Japanese Canadian 
subject" or interrogate Japanese Canadian subject formation in literature, there has been little critical engagement with the formation of white subjectivity in relation to this violence or the cultural/academic production that claims to represent it. We have thus participated in the processes of forgetting this history as one which is also about white subject formation and a collective white domination. White people, including both those with whom Japanese Canadians had direct contact as well as those who are constructed as unimplicated in the Internment remain largely absent in our texts.

Most of the people who had lived in Ann's community on Vancouver Island were moved to Tashme. She lost contact with them during her incarceration in Slocan. She states that she wouldn't have been able to "write very much anyway because all the mail at that time was censored."120

Ann's memory of being imprisoned in Slocan was informed by what she later learned from those who were "caught" in Japan during the war and those who were forced to go to Japan after the Repatriation Survey. Some of these people were relatives. She describes their experience as "miserable. They had a pretty hard time when they went to Japan." "121

While I did not interview any women who lived in Lemon Creek, letters I found in the National Archives give an indication of what two women experienced in that space of incarceration and their individual protests to the government. One woman's letter requesting that the government release her husband from a POW camp because she was due to give birth indicates how the Internment and her separation from her husband profoundly affected her. She states, "When I look past through the nine months [of pregnancy], it wonders me that I am the same person yet, there were times when I felt like doing away with myself." 122 She adds that "Usually to happy married people [having a baby is] a great event but not so... with my beloved in a far off internment camp." ${ }^{123}$ She states that she is dreading giving birth in this space of separation.

In a letter to the Canadian delegate for the Red Cross, a woman asks why a previous letter was not answered. The correspondent had tried to get an interview with the delegate when he visited Lemon Creek but was unable to see him. She also states that her husband and two sons were interned in a POW camp and they had written several times requesting their release. In her letter, the woman describes how the Repatriation Survey 
was being used to coerce people who were in difficult situations to sign to go to Japan. She states that she agreed to go to Japan in order to allow her son to be temporarily released from Lemon Creek to do seasonal work in Vernon. Her son needed to earn money to pay for his high school entrance fees. She explains how difficult this decision was for her because she "did not know definitely what [her] husband would do." 24 If she had not signed the government survey, her son would not have been able to leave Lemon Creek. She explains, "Because he was not able to go I signed for repatriation...thinking it was the only way to let my son have his necessary High School Education. This is the only reason I signed the form." 125 She ends the letter by asking for the release of her husband and sons, explaining that "our separation for four years have been very unhappy years, and our only wish now is for family reunion."126

\section{Rosebery}

A government report barely mentions Rosebery but rather focuses upon the site of New Denver City. Rosebery is included as part of the "New Denver Evacuation Area," sixteen miles north of New Denver City. ${ }^{127}$ Rosebery, however, was a distinct incarceration site, inhabited by 219 adults and 137 children on 3 June $1943 .^{128}$

In a letter written by a man incarcerated in Rosebery to the Minister of External Affairs, we are given an account of the multiple separations occurring within one family. The writer was asking for the release of his brother from a POW camp so that he could take care of his child, aged two, who was separated from her mother and placed in the New Denver Sanatorium. The writer explains that he is taking care of his brother's older child but cannot take in the younger one because his wife was going to have a baby. The two-year-old was kept in the Hastings Park Hospital with her mother until she was moved to New Denver. The mother of the children was then moved to the St. Joseph's Oriental Hospital in Vancouver awaiting an operation. The brother explains that he is concerned for the welfare of the "baby" because the staff of the New Denver Sanatorium "wishes to have her placed in a foster home."129 He asked that the minister grant the release of his brother to New Denver "where he can keep his family intact." 130

The Welfare Manager at New Denver, a white woman, would not support the request to release the children's father. In her letter to her supervisor she states that a 
foster home had been found for the younger child in one of the camps and that as soon as it was approved by the Children's Aid Society in Vancouver, the child would be moved from the Sanatorium. She argues that she does not think that the father could "give the proper care to two small children," and the children "will most probably receive better care in the foster-home in which Worker intends to place her." ${ }^{131}$ She adds that the worker will make monthly visits to the foster home. George Collins, the General Supervisor for the $\mathrm{BCSC}$, refused to give permission to release the father from the POW camp. ${ }^{132}$ Not only were the parents separated from each other and their children, but the two siblings were to be separated in different prison camps. In these multiple separations orchestrated through state processes, we witness the ways in which surveillance was spread through the spaces of incarceration. Not only was this one family markedly affected and divided through incarceration but the separations were supported by the people who enacted practices of surveillance and who ultimately benefited through employment during the Internment. It must also be emphasized that it was white officials who considered it inappropriate that a man care for his children and instead designated care of his children to a "foster home."

Kazuko described growing up in Haney and living in a community where most of her friends were Japanese Canadian and "everybody was very close to each other and friendly." 133 She remembers her school days there as being "very happy." Kazuko was eighteen when she was removed from her home in Haney to Hastings Park. From Hastings Park, she reports being moved to Neys Hostel in northern Ontario and then to Rosebery. ${ }^{134}$ When I asked her if other people from Haney were moved to Rosebery, she replied, "No, we were all scattered." ${ }^{335}$ Her description of Rosebery is constructed in relation to the prison camp in New Denver. She reported that there were few organized activities in Rosebery as compared to what she knew of the activities organized by people held in New Denver. She described Rosebery as being on the outskirts of New Denver and "there was nothing" there. ${ }^{136}$

Kazuko found there were few people her age in Rosebery; there were generally older or much younger children. In contrast to the reports made by Louise and Yoshiko, who had positive memories of being cared for by older women in the communal bathhouses, Kazuko "dreaded going" to the bathhouse in Rosebery. ${ }^{137}$ She explains that 
"it was really a fight because a lot of people use a lot of water and if you use more water, well, then the other person doesn't have any hot water. And so that was quite a trouble. So that part we didn't enjoy at all."138

A major concern for Kazuko, as a young woman, was the worry about money, contributing financially to her family, and not being able to find employment in the prison camp. She reported that while some people found work in the government office, "the majority couldn't get a job." ${ }^{39}$ For her and her family, "it was very, very hard living."140

More than once in her interview, however, she indicates how her family was "lucky" as compared to those whose families were separated. Despite the financial difficulties her family experienced during the Internment. she realized that men who contributed to the family income were usually removed from the family in doing so. She states, "actually the men had to separate from the family. But fortunately we were very lucky. Somehow we were all together, most of the time, the evacuation time." "i41 But she is also clear that the Internment deeply affected their lives in her statement, "But it wasn't really a life at all, all those years." 142

Another example of Kazuko's "memory of community" and how her memory is constructed relationally is when I asked how she later met her husband in Toronto. She then described to me how her husband had been incarcerated in a prisoner-of-war camp:

He was in an internment camp and he was treated terribly. They were whipped around, all over...he said he worked for seven cents an hour. And oh, they really, they were just watching you and the minute you just light a cigarette or anything...they got a whipping.... He had a terrible time. I think he had a worse time than I did..$^{143}$

This knowledge of her husband's experience in a prisoner-of-war camp impinges upon how Kazuko re-members her experience of Rosebery. as does the knowledge that others were separated through this period. The pain and trauma of her husband's disclosure came after her own incarceration in Rosebery, knowledge imparted through their relationship in Toronto. The very displacement of these two people also served to continually displace memories, as the piecing together of fragmented geographies is always incomplete though connected, gaping with the fissures of the "missing" and geographical spaces haunted and haunting. These "past" ruptures of relationships and communities continue to leak into the present. Our memories suffer from the weight of 
incompletion, reminded as we are in the momentary "image" flashing "up at the instant" of meeting one of the missing or someone who notes we or our loved ones were/are missed.

In the totality of the Internment, Kazuko situates herself relationally to others who suffered and lost differently than she. Later in my interview with her, I asked her about the Repatriation Survey and it triggered the memory of her eldest brother, with whom she had lost contact due to their separation during the Internment. Re-membering the spacial configurations of their separation and her brother's decision to go to Japan, invokes this memory of her loss:

Oh, I forgot to tell you...I had a big brother, too, that was born in Japan.

But he didn't come with us. He went on his own. Yes.... And then he went to Tashme but he got married in New Denver. And then when we had a choice of going to Japan or coming here, well, he chose to go to Japan. So ever since that we haven't got in touch with him.... We don't know whether he's dead or alive or..... We tried everything. ${ }^{14}$

How to keep the threads together, how to re-member everyone who was lost, how to forget/not forget one's own losses or re-member that other's losses are one's losses too.

In reconstructing the spatial differences, sites of exile spread across a nation, Kazuko re-members her brother's exile from nation, from family, from her. She remembers she hasn't seen him since her family was allowed to attend his wedding in New Denver and in her urgent telling of nearly forgetting, I feel she is reminding me that I must re-member him. Efforts to find him across the geographical borders dividing "enemy" nation from Canadian nation, across the boundaries that contained and excluded Japanese Canadians within a nation through legislative restrictions, censorship of mail, continued displacement, and economic hardship proved futile. She describes this interminable separation in this way, "We don't know how he, what he's doing or if he's not living or.... It's a terrible feeling, you know... we really feel bad about that.... But it's too late now. We think that he is gone anyways."145 


\section{Another B.C. Interior Prison Camp}

Haru grew up in Vancouver in a "Japanese community." Most of her friends had been "Chinese and Japanese" students at Strathcona high school. She had Japanese friends with whom she went to Japanese language school after her day at high school. On the weekends, she socialized with her Japanese friends. Socializing with hakujin friends ended at 3:30 p.m. when they left the high school space of Strathcona.

Haru was nineteen when she was moved from Vancouver to an interior prison camp. ${ }^{146}$ She reconstructs her memory of the camp in relation to how she perceived the experience of her younger siblings. She describes how she felt her sister "had the greatest time. She was so young." 147 She reports that this younger sister was allowed to go out to camp activities because her younger brother would "chaperone." Being the eidest, she "didn't have a chaperone" and wasn't allowed to socialize in the same way. She thus remembers her time in the prison camp as more difficult than that of her siblings.

Like Ann, Haru reported that some of the women got together to cook in the prison camp. She said that some of the families had "older sisters who had worked in the hakujin housework," and they knew "how to make cakes."148 Her mother, however, "didn't have time to cook anything fancy or learn how."149

Haru had been attending high school in Vancouver, but after she was moved to the prison camp she was unable to continue her high school education. Instead, she went to a sewing school opened by a Japanese Canadian woman. She reported how two of her classmates were moved from their families in different incarceration sites to attend the sewing school. She added, "I had my family there." ${ }^{\text {so }}$ Haru also volunteered in the camp, assisting a friend who taught kindergarten. She had often been asked to assist teachers and take over classes when she lived in Vancouver. She told me, "I really, really wanted to become a teacher when I was going to high school. I really enjoyed it.... But then I couldn't further my studies." 151

Haru is also conscious of the other sites of incarceration and she mentions to me she knew that living in the "self-support" communities was difficult. She describes how her cousin went to a "self-support" community. Her cousin's husband was removed to a prisoner-of-war camp, referred to by Haru as a "concentration camp," leaving her with her father and brother. Even though Haru is aware that a criterion of living in the "self- 
support" camps was "if you had money," she describes how "there was no money coming in" for her cousin's family and "so they had to work. They really worked hard, working on other people's farms and seasonal things." 152 Haru's memory also reveals how her cousin was not moved to the Tashme prison camp, site of many "internees' families," as was described by Aya, illustrating how different hierarchies were maintained and cultivated by the government throughout the prison camp system.

Like S., Haru kept in touch with the "missing" through correspondence. She states, "It was the only way to keep in touch because we were scattered all over. I used to write to a lot of boys and girls that went to work somewhere else." 153 She says that she has kept photographs of people she knew and her children have said to her, "my gosh mom, you've got so many boyfriends."154 She has explained to them that these photographs of men were "not actually boyfriends. But if they were going to leave for the road camp or other places, they gave you snaps and signed in our autograph books."155

As earlier stated, the War Measures Act gave the government sweeping powers. legislated powers they mobilized in enacting and legitimizing the Internment. These powers included the "censorship and the control and suppression of publications... and means of communication." 156 The following is an extract from instructions given to Japanese Canadians by the Canadian Postal Censor in Vancouver:

Write in English. If in Japanese, it should be confined to essential news and information, avoiding inconsequential gossip... Do not slow up the Censor's reading by using unusual [Japanese] symbols.... Do not enclose in envelopes addressed to Occidentals correspondence to be passed on to Japanese nationals. This places upon the Occidental the duty of reporting your action to government authorities. ${ }^{157}$

Haru reports that her letters were "all censored" during the war. Even in the "private" space of letters, the only means of communicating with the "missing," the government controlled what was conveyed through censorship. Not only were the spaces of incarceration policed, but so too were the attempts to create and maintain intimate relational spaces across the boundaries of incarceration and displacement. The orders from the Censor also clearly authorized white people to betray the contents of personal correspondence and the correspondents if they deemed it appropriate. In this way, the 
government extended the powers of policing and punishment to every white person outside of the spaces of incarceration.

Haru describes how she "was getting very unhappy" in the prison camp site. ${ }^{158}$ Competition for the limited jobs in the camp created divisions amongst people. Haru had worked at a fruit and vegetable store in Vancouver and had hoped to get a job in the prison camp store. When all job opportunities failed, she decided she had to leave her family in order to contribute to it financially. She took a domestic job in northern Ontario. She states, "There were a lot of domestic jobs coming out of the ghost towns, to come out east, you know."159

\section{Conclusion}

Assumptions about a raced masculinity and femininity were part of the construction of the different sites of incarceration and forced labour. What I have introduced in this chapter is the methodological approach of analyzing systems of domination as interlocking. I have attempted to reveal how gender was operationalized in the spatial construction of the British Columbia interior internment camps. These processes of en-gendering female and male subjects cannot be viewed as a closed subordinating dynamic between Japanese Canadian women and men. Rather. I have sought through this chapter to illustrate the ways in which government policies and administrative practices mobilized and further secured a hegemonic white bourgeois masculinity.

In the next chapter, I will continue to use the methodology of analyzing interlocking systems of domination and illustrate how class differences were mobilized in the construction of the spaces of incarceration.

\section{Endnotes: Chapter Five}

1. Razack, Looking White People in the Eye, p.13.

2. Aya [pseud.], interview by author, tape recording transcript, pp.65-66.

3. Kobayashi, "The Historical Context," p.76.

4. Ioid. 
5. Lowe, Immigrant Acts, p.83.

6. Interview with S., p.15.

7. Interview with Evelyn, p.27.

8. Ibid.

9. Ibid., p.29.

10. Ibid. The Vancouver Exhibition Association held fairs in the winter and summer. The livestock buildings of the fair grounds were expropriated in March 1942 and "converted" in seven days to house people. This site was more commonly known as Hastings Park Manning Pool. See Sunahara, The Politics of Racism, p.55. In 1946, the name of the exhibition was changed to the Pacific National Exhibition and Hastings Park was renamed Exhibition Park. Authors David Breen and Kenneth Coates suggest that the park's renaming was proposed in 1939. Breen and Coates, Vancouver's Fair: An Administrative and Political History of the Pacific National Exhibition (Vancouver: University of British Columbia Press, 1982) p.106.

11. Interview with Evelyn, p.29.

12. Ibid., pp.29-30.

13. Interview with Margaret, pp.26-27.

14. Ibid., p.90.

15. Interview with Aya, pp.19, 23-25.

16. Ibid., pp.30-31.

17. Interview with Louise, p.14.

18. Canada, BCSC, Removal, p.20.

19. Interview with Aya, p.30.

20. Interview with Louise, p.15.

21. Ibid., p.42.

22. Ibid., p.35.

23. Ibid., p.42.

24. Ibid., p.67.

25. Ibid., p.13. 
26. Webster's New World Dictionary, third college edition (Cleveland and New York: Simon and Schuster, 1988) defines a Boy Scout "Jamboree," as "a national or international assembly of Boy Scouts," p.722.

27. Catherine Lang, O-Bon in Chimunesu (Vancouver: Arsenal Pulp Press, 1996), p.22. See also Lang's description (p.22) of how Yoshida was denied membership in the Chemainus white boy scout troop in the pre-Internment period. As a result, he took a correspondence course on scouting and formed his own troop in Chemainus in 1930, a troop that had "the distinction of being comprised exclusively of Japanese Canadian boys."

28. For a description of the Christian churches' involvement in the interior prison camps, see for example Roland M. Kawano, ed., Ministry to the Hopelessly Hopeless

(Scarborough, ON: The Japanese Canadian Christian Churches Historical Project, 1997).

29. For a brief description of education in the interior prison camps, see Mary Ashworth. The Forces Which Shaped Them (Vancouver: New Star Books, 1979), pp. 117-132.

30. Interview with Louise, p.21.

3 I. Ibid., p.22.

32. Ibid., p.30.

33. Canada, BCSC, Removal, p.25.

34. Ibid., p.26.

35. Interview with S., p.16.

36. Ibid., p.40.

37. Ibid., p.35.

38. Ibid., p.40.

39. Ibid., p.35.

40. Adachi, The Enemy That Never Was, pp.251-252.

41. See for example Prime Minister Jean Chrétien's 1998 statement regarding the RCMP use of pepper spray against protesters of the 1997 Asia-Pacific (APEC) summit held in Vancouver: "Instead of picking up a baseball bat or something else, they are now trying to use more civilized methods." Chrétien quoted in editorial: "Chrétien's quips inspire no confidence," Toronto Star, 21 October 1998, p.A20.

42. Canada, Administration, p.11.

43. Interview with S., p.35. 
44. Ibid., p. 19.

45. Ibid., p.20.

46. Canada, BCSC, Removal, p.25.

47. Ibid., p.34.

48. Ibid., p.28.

49. Ibid., p.26.

50. Ibid., p.44.

51. Kitagawa corresponded with her brother, Wesley Fujiwara, between I 3 December 1941 and May 1942. Kitagawa, This is My Own, pp.67-151. According to Adachi, censorship of the mail began in August 1942. Adachi, The Enemy That Never Was, p.267.

52. Spain acted as the Protecting Power for "Japanese" interests in Canada and the United States. The Consuls for the Spanish government were located in Montreal and Vancouver. Only Japanese Nationals were covered by this agreement with Spain. Information from Canada, Department of Labour, Administration, p.30.

53. NA, Records of the Department of External Affairs, RG 25, G2, vol.3005, file 3464AC-40, "Petition from Ten Japanese Women," Correspondent to Pedro Schwartz, 26 December 1942. I have not disclosed the names of the correspondents whose letters are in the possession of the National Archives.

54. NA, Records of the Department of External Affairs, RG 25, G2, vol.3005, file 3464AC-40, "Petition from Ten Japanese Women," Correspondent to P.E. Schwartz, 4 May 1943.

55. NA, RG 25, G2, vol.3005, file 3464-AC-40, "Petition from Ten Japanese Women," Correspondent to Daniel de Yturralde, 18 October 1944.

56. Ibid.

57. NA, RG 25, G2, vol.3005, file 3464-AC-40, "Petition from Ten Japanese Women," Correspondent to Louis St. Laurent, 18 December 1944.

58. Ibid.

59. NA, RG 25, G2, vol.3005, file 3464-AC-40, "Petition from Ten Japanese Women," Correspondent to Fernando De Kobbe, 12 January 1942.

60. Canada, BCSC, Removal, p.24.

61. Interview with Yoshiko, p.21. 
62. Ibid.

63. Ibid., p.43.

64. Ibid., pp.44-45.

65. Ibid., pp.25-26.

66. Ibid., p.25.

67. Ibid.

68. Ibid.

69. Ibid.

70. Ibid., p.26.

71. bid., p.12.

72. Ibid., pp. 12-13.

73. Ibid., pp. 13-14.

74. Ibid., p.44.

75. Ibid., pp.48-49.

76. Ibid., p.31.

77. Ibid., p.23.

78. Ibid., p.26.

79. Ibid., p.47.

80. One could speculate that this report of women only as being partnered with white people was a way of occluding the fact that Japanese Canadian men were partnered with white women. This omission may have been a paternalistic proprietary gesture of white men seeking to discursively "keep white women to themselves." Disclosing this information may have also countered the image of the "alien" Japanese man that was so critical to the justification of the Internment. Of course, more research is needed to further analyze the government's policy and its impact on those partnered with non-Japanese Canadians and their children.

81. Note that Ken Adachi states that "92 persons, representing Japanese married to whites and their children, were issued permits on April 11,1942..." Adachi quotes his source as Canada, BCSC, Removal. Adachi, The Enemy That Never Was, Table 7, p.415. 
82. Canada, BCSC, Removal, p.7.

83. NA, RG 36/27, vol. 1, file 17: "Distribution of Japanese," "Japanese Population in the Dominion of Canada as of February 29th, 1944," p.6.

84. NA, RG 25, vol.2939, file 2997-40, part 1, "Japanese Population in the Dominion of Canada as of June 30th, 1943," p.2.

85. NA, RG 25, vol.2939, file 2779-40, part 2, "Japanese Population in the Dominion of Canada as of August 31st, 1945," p.2.

86. NA, RG 25, vol.2939, file 2779-40, part 2, "Japanese Population in the Dominion of Canada as of October 31st, 1946," p.1.

87. NA, RG 36/27, vol.1, file 17: "Distribution of Japanese," "Japanese Population in the Dominion of Canada as of October 31 st, 1944," p.5.

88. NA, RG 36/27, vol.1, file 17: "Distribution of Japanese," "Japanese Population in the Dominion of Canada as of November 30th, 1943," p.4.

89. Elena Tajima Creef, “Re/Orientations," p.97.

90. Estelle Peck Ishigo, Lone Heart Mountain (Los Angeles: Communicart, 1972). See also Stephen Okazaki's film depicting Ishigo, Days of Waiting, discussed in Creef, "Re/Orientations," pp.98-100.

91. Creef, "Re/Orientations," p.113.

92. Interview with Yoshiko, p.42.

93. Ibid., p.24.

94. Ibid., p.42.

95. Ibid., pp.20-21.

96. Interview with May, p.34.

97. Ibid., p.35.

98. Ibid., p.36.

99. For a description of Hide Hyodo, see Ann Sunahara, The Politics of Racism, p.97. Also note that Hyodo was one of the members of a four-person delegation that appeared before the Special Committee on Elections and Franchise Acts of the House of Commons on May 22, 1936, lobbying for the vote for Japanese Canadians who were Canadian citizens. Hyodo was the only woman delegate. See Adachi, The Enemy That Never Was, pp.160-164. 
100. Interview with May, p.49.

101. Ibid., p.57.

102. Ibid., pp.33-34.

103. Ibid., p.39.

104. Ibid., p.35.

105. Ibid., p.39.

106. NA, RG 36/27, vol.I, file 17 "Distribution of Japanese," "Memorandum Covering Japanese Movement Pacific Coast," 18 July 1942, p.2.

107. Ann [pseud.], interview by author, tape recording transcript, I November 1996, pp.51-52.

108. Canada, BCSC, Removal, p.24.

109. Mayumi quoted in interview with Ann, p.36.

110. Interview with Ann, p.37.

11 1. Ibid., p.40.

112. For example, when I asked Ann how old she was when the war started, she replied, "World War I?" I, of course, was referring to the war with Japan.

113. Interview with Ann, p.41.

114. Ibid., p.42.

115. Ibid., p.43.

116. Ibid. Kay Anderson describes "Shaughnessy" as "Vancouver's British-origin neighbourhood," emphasizing its elite spatial positioning in the métropole. Anderson, Vancouver's Chinatown, p.30.

117. Sunahara, The Politics of Racism, p.91.

118. Langer, Holocaust Testimonies, p.148.

119. Ibid.

120. Interview with Ann, p.50.

121. Ibid., p.51. 
122. NA, RG 25, G2, vol.3005, file 3464-AC-40, "Petition from Ten Japanese Women," Correspondent to Pedro. E. Schwartz, 28 January 1943.

123. Ibid.

124. NA, RG 25, G2, vol. 3005, file 3464-AC-40, "Petition from Ten Japanese Women," Correspondent to Ernest L. Maag, 20 July 1945.

125. Ibid.

126. Ibid.

127. Canada, BCSC, Removal, p.23.

128. NA, RG 25, Volume 2937, file 2997-40, part.1, "Japanese Population in the Dominion of Canada as of June 30, 1943," p.1.

129. NA, RG 25, G2, vol.3005, file 3464-AC-40, "Petition from Ten Japanese Women," Correspondent to Minister of External Affairs, n.d.

130. Ibid.

131. NA, RG 25, G2, vol.3005, file 3464-AC-40, "Petition from Ten Japanese Women," Isabel G. Stott, to Mr. Swain, 21 May 1943.

132. NA, RG 25, G2, vol.3005, file 2464-AC-40, "Petition from Ten Japanese Women," George Collins to RCMP Constable R. Davidson, 25 May 1943.

133. Interview with Kazuko, p.6.

134. Sunahara states that hostels such as Neys were established around 1946 to facilitate the dispersal. See, Sunahara, The Politics of Racism, pp.140-141. Joseph Fry also states that Neys Hostel was used between the summer of 1946 to the summer of 1947. Fry. "Omoide Garden," More work is needed to detail the uses of these "hostel" sites. The chronology of Kazuko's enforced displacement is not of issue to me here. What is revelatory in her testimony are the multiple displacements suffered by her and what she re-members of the disorientation and violence of forced displacement.

135. Interview with Kazuko, p.25.

136. Ibid., pp.32-33.

137. Ibid., p. 15.

138. Ibid., p.16.

139. Ibid., p.32.

140. Ibid., p.32. 
141. Ibid., p. 12.

142. Ibid., p.27.

143. Ibid., p.23.

144. Ibid., pp.45-46.

145. Ibid., p.48, 52.

146. Haru has requested that the name of the prison camp not be used.

147. Interview with Haru, p.58.

148. Ibid., p.60.

149. Ibid.

150. Ibid., p.46.

151. Ibid.

152. Ibid., p.49.

153. Ibid., p.71.

154. Ibid., p.70.

155. Ibid.

156. Sunahara, "Legislative Roots of Injustice," p.7. See, also, Adachi, The Enemy That Never Was," p.220.

157. Adachi, The Enemy That Never Was, p.267, note omitted.

158. Interview with Haru, p.58.

159. Ibid., p.47. 


\section{Chapter Sex \\ ECONOMIES OF GENDER: \\ THE "SELF-SUPPORT" INCARCERATIONS, \\ SUgAR BEET FARMS, AND DOMESTIC WORK}

\section{Introduction}

In Chapter Five, I illustrated how the violent spatializations of the prison camps were sites of en-gendering for women. In this chapter I will continue to utilize the methodology of understanding systems of domination as interlocking by demonstrating how class was also an enabling discourse and practice in the construction of the sites of incarceration. I emphasize that these two distinctly chaptered delineations of the different sites of incarceration present perhaps a sense of autonomous sites, where only one system of domination was mobilized. In fact, my work intends, through its spatial analysis, to illustrate how the sites of incarceration were relationally struciured, and depended upon and produced interlocking systems of domination. It also seeks to raise questions about the contradictions in occupying both dominant and subordinated subject positions and suggests that none of "these valences of otherness" (for example, class, race, gender, sexuality, ability) is "independently articulated." Unfortunately in my own struggle to achieve and represent the multi-dimensional overlappings of physical, mental, and social spaces, my writing has still fallen prey to the seeming necessity of a linear narration. ${ }^{2}$

In section one of this chapter, I will discuss one site of "self-support" incarceration, Lillooet. In section two, I will look at the Manitoba sugar beet projects as sites of forced labour. The final section will examine the space of domestic service. I will also continue to demonstrate how the violent destruction of families and communities was attained through these sites of incarceration and displacement.

\section{"Self-Support" Incarcerations}

In the case of the "self-support" incarcerations, the government mobilized the class divisions within the Japanese Canadian community in setting up a distinct category of people who were to support themselves by living on their savings for an indefinite period. 1,400 people were sent to Christina Lake, Bridge River, Lillooet, McGillivray Falls, and Minto City where they leased land and lived under government restrictions. ${ }^{3}$ A 
government report stated that the "self-support" communities were created as separate sites from the interior internment camps "as it was felt that the presence of these families in the maintenance towns might create a disturbing influence by giving rise to class distinction." Around 300 other people, who also were to pay for their own upkeep during the incarcerations, were moved to Taylor Lake and Westwold. ${ }^{5}$ While the material criterion for movement to these sites of incarceration seems to have been access to money, what, of course, this category of "self-support" conceals is the fact that people living in these communities were also being monitored, restricted in their movements, and subjected to hardship. A full-time "supervisor" was responsible for the "inspection and checking of their activities" in the "self-support projects."6

Evelyn was eleven when she was moved from Vancouver to Lillooet. She described how her father went to the government office to register the family for an Alberta destination. At the office, he asked the officials, "what about our children's education?" Evelyn describes how he was told, "'Jap' kids don't need education" and how this infuriated her father and "he raised a huge cuffuffle" and turned a table over." The RCMP head officer called him into his office and told her father there was another "choice" and that was self-support in Lillooet. According to Evelyn, her father was told he would have to "build [their] home, and take all his supplies and limited luggage."

According to Sunahara, some people who were forced to move to the "selfsupport" incarceration sites leased "special" trains. ${ }^{10}$ In contrast to Margaret, Evelyn does not remember her train trip as difficult. Although they both have memories of a certain "excitement," which they attribute to being children and protected from the meaning of the displacement by some of their elders, there are qualitative differences in their experiences attributable in part to their class positions. For example, Evelyn remembers stopping en route to Lillooet and being able to stay at a hotel and have breakfast there. This is contrasted to Margaret's story of sitting in the cane seats of a train for four days in her forced movement to Manitoba. What is important to note, however, in the case of the people who were forced to move to "self-support" sites is how class privilege did not protect them from spatial exclusions during the Internment, including the mass expulsion from the coastal area and the exclusionary practices encountered in their sites of incarceration. Class differences, however, must also be further analyzed in order to 
understand how class operated in constituting differences within racialized spaces. This understanding of class as part of an interlocking system of domination must also be recognized as operational in the ways in which people describe and re-member the spaces of incarceration. For example, people forced to move to the "self-support" sites may be reluctant to name the hardships encountered within those spaces due to their understanding of how class situated them within a hierarchy of carceral spaces. Another issue for further investigation would be to understand what class privilege during the Internment secured in the post-Internment period. Paying for their own incarcerations necessarily depleted the financial resources of all Japanese Canadians.

Upon their arrival in Lillooet, Japanese Canadians were not allowed to go into the town of Lillooet "across the river" but had to live in East Lillooet. As Evelyn states, "We discovered that we were not allowed to go into town, that we were the enemy, I suppose."11

Evelyn's father had built their house prior to their arrival. The "house" as Evelyn described it was more like a "hut." When they arrived, the door wasn't completely hinged to the doorframe and they awoke "in the middle of the night, looking out of this halfclosed door, seeing the cows' heads looking down at us." 2 She states that "lots of wild cows" roamed the property to which they were restricted. The land on which they lived was leased from a white owner who continued to live on a midsection of the property. Evelyn also reported that there was a visible presence of RCMP officers and an "RCMP town" nearby. ${ }^{13}$

While Evelyn points out that for her, being in Lillooet was not a "big distressful situation," she also states after describing their exclusion from the town of Lillooet, "I guess it was not pleasant."14 She also quickly points out that even though they were not allowed within the town itself, the town's three general store owners came to East Lillooet to take orders for supplies. She adds, "I think it was a boost in their economy."15 She later tells me that there was an epidemic of stomach problems and this was attributed to their water supply. The closest hospital was in Lytton, fifty miles from Lillooet. As a result of the epidemic, people organized to demand a cleaner water supply and the town of Lillooet eventually agreed to truck in water to them for a fee. 
Japanese Canadian children were not able to attend the school in the town of Lillooet. While the elementary school was being built in East Lillooet, the funding for which was provided by those incarcerated, Evelyn took classes in a tent. High school students had to take correspondence courses if they wished to continue their education and Evelyn remembers taking correspondence courses for subjects like typing that were not part of the basic matriculation curriculum. When Japanese Canadian children were finally able to attend the high school in Lillooet, the trip to and from school took four hours on foot. One of Evelyn's teachers was from Saskatchewan. She remembers him telling the Japanese Canadian students, "You're such nice kids. I can't get over it. The only way I knew about you people was through a comic strip...yellow skin and great big teeth." ${ }^{16}$ While living close to a white established community distinguished the Lillooet incarceration site from some of the "ghost town" prison camps. Evelyn's descriptions of the exclusions they encountered are indicative of their experience of violence in that site.

In order to avoid the daily four-hour walk, Evelyn accepted a live-in job babysitting and doing dishes for a white family. This meant that she saw her family only on the weekends. She states, "I just detested that winter walk home" and reported that "other girls" were also doing domestic work while attending the high school. ${ }^{17}$ Although Japanese Canadians were not allowed to live within the town's borders, they could temporarily enter white spaces through their labour. Evelyn again demonstrated her knowledge of how their incarceration benefitted the white townspeople. She saw this direct benefit when they were finally allowed to attend the Lillooet high school "because that gave them more money to develop the schools. Even in Lillooet there weren't enough students to have grades eleven and twelve. So by our coming, they were allowed to have grade eleven and twelve" and the higher grade white students no longer had to move to Vancouver. ${ }^{18}$ Evelyn's experience also illustrates how children's labour was utilized during the Internment, something rarely written about in Internment narratives, except sometimes in passing, within the context of children working on the sugar beet farms. This also serves to render a different conception of the Lillooet community from that conferred by the term "self-support."

Evelyn points out the "irony" that there is now a bridge over the Fraser River directly linking East Lillooet and the town of Lillooet. At the time of the incarceration the 
only existing bridge crossed the river at a point distant from both the town and East Lillooet, therefore necessitating the four-hour trek. Evelyn also, however, emphasizes to me that her family "was lucky" and did receive some material support from her father's former business contacts. This assistance came in the form of food at Christmas.

The notion that the "self-suppor" incarcerations kept families together is a complicated construction that is further problematized in Chapter Seven. The governmental definition of family used to describe these incarcerations in this way drew upon a patriarchal notion of family where a man is the head of the household. The "selfsupport" sites did differ from the B.C. interior prison camp spaces in that men were allowed to live in this site as long as they could financially support themselves. This is compared to the experience of men who were removed from their families because they had to work outside of the incarceration site to support themselves. What the government therefore set in place was a reinforcement of male domination in the claim that families were intact because the male "head" of the family was present. This hegemonic notion of family, however, denied how families were multiply constituted by Japanese Canadians; their construction of family went beyond connections of blood to include historically valued relationships. The governmental discourse of "keeping families together" was another linguistic masking of the violence of destroying communities.

Despite the notion that "self-support" communities kept families together, the Internment profoundly affected members of Evelyn's family. Her maternal grandparents were sent to an interior prison camp and she did not see them until they were reunited in Vancouver after the restrictions were lifted. When I asked her what it was like to see her grandparents after so many years, she responded by telling me about her grandmother. She described how "She'd go for a walk and she'd be knocking on doors asking, 'Oh are my children here? Are my children here?' She was looking for her children."19

How do we measure the losses: A mother missing her children, absented through government order?

Reuniting with her family did not change the absences created through years of separated incarceration for Evelyn's grandmother. A mother continues to look for her children after they have been taken from her, displaced to sites unseen that she could only imagine. Displacement and incarceration become normalized as necessary for the 
marginalized, while Evelyn's grandmother is pathologized by the nation that incarcerated her. Displaced from her home and her family, she is re-displaced to what was formerly the space of home but can never be home in the same way, given the people who are missing from that space and the spaces of missing she carries within her. When she enacts this re-membrance she once again looks to others, continuing to entrust others from another community to which she has been displaced. In this enacting and re-enacting of memory, she makes visible the embodied trauma of her loss in the spaces delineating "private" Vancouver homes upon whose doors she knocks. Whose silence is invisible here?

In the model that is held over us, "the autonomous, rational subject" is the epitome of western civilization. A nation that destroys community relegates memory to the "individual," and Evelyn's grandmother is left to carry the burden of re-membering the spatial separations from her children and her community.

This searching for her children enacted by Evelyn's grandmother is a profoundly gendered experience. Her continual search, as a woman, mother, grandmother, makes visible how pathological and violent was the Internment and how its legacy seeps into our lives years beyond the initial destruction of our communities on the west coast. The spaces of Evelyn's family's incarcerations were not disconnected from the spaces to which they were eventually displaced. The incarceration and displacements carved up families and communities, remapping the national landscape by forcibly moving people to other spaces.

While we must acknowledge the hierarchical arrangement of the spaces of Internment and displacement of Japanese Canadians, we must also look at the how these spaces serve to disguise the violence that occurred within and through them. If we do not see beyond the government's rhetoric of, for example. "keeping families together" in the "self-support" communities, we miss seeing the violence done to all families and the very notion these families had of "family" and "community." If we do not see how gender was operationalized in these racialized spaces, we miss seeing the complex and interconnected construction of violence.

As is illustrated by Evelyn's account, many of those incarcerated in East Lillooet also laboured in different ways to support themselves. Evelyn's example also complicates 
a discourse constituting "self-support" as unitarily that of privileged families when we examine the circumstances of her incarceration and also that her parents' access to funds did not preclude the incarceration of her maternal grandparents in another non-"selfsupport" site. What also gets obscured by the term "self-support" is that people in the non-"self-support" camps were also required to support themselves as much as possible including through the proceeds of the government's liquidation of their possessions. What gets forgotten again in a particular government rhetoric is the violence of the sites of incarceration.

\section{Sugar Beet Farm Incarcerations}

According to a government report, 3,64l people were moved to Alberta and Manitoba to work on sugar beet farms. ${ }^{20} 1,053$ people were moved to Manitoba. ${ }^{21}$ In describing how "family groups" were sent to work on the sugar beet farms in Manitoba and Alberta, the BCSC described how the "preservation of the family group appealed to the Japanese."22 It added that men from these families were "recall[ed] from Camp" and moved to "their newly reunited families" in the prairies provinces. ${ }^{23}$ As we have seen, the government's notion of the "family" was different from that held by the people incarcerated. What is clear from the process of moving people to labour on sugar beet farms is that some men were allowed to remain with their families in these carceral sites because their labour was required and "due regard... [was] given to the number of workers in each family."24

350 men were also sent without their families to work in Ontario on sugar beet farms. ${ }^{25}$ As is clear from the insistence that all single able-bodied men work in road camps (see Chapter Four), the government constructed the sites of these camps in relation to the labour needs of both national and provincial governments. We have also seen how men left the interior prison camps to work in projects such as logging. The interior camps were actually envisioned as but one "step in evacuation," and further "steps" were construed in relation to work and the sending of "family groups" from the camps to forced work projects "wherever they may engage in available industry." 26 In 1942 the government stated its "primary principle" was to ensure "all available man power and woman power be utilized." 27 It added that it would constantly endeavour to "relocate as 
many as possible in other parts of the Dominion," which would alleviate the "country's labour shortage" and "make them financially independent of the Government assistance." 28

I am not, however, imputing a deterministic relationship between capitalism and the construction of the sites of incarceration. Rather, I wish to illustrate how complex systems of domination were mobilized spatially to enable class differentiations and the gendered constitutions of work. ${ }^{29}$ The interdependent spatial relationships of the sites of incarceration within a wartime capitalistic economy are perhaps most clearly witnessed in the sites of the work camps and the sugar beet farms. As was discussed in Chapter Five, what is less visible and acknowledged as such is the work done by women in the prison camps, especially the work of childcare, and how this labour enabled other forms of labouring to be done by men. ${ }^{30}$

I would underline here the contradictory tension resounding throughout the spaces of incarceration, that is the fact that Japanese Canadians were deemed to be disloyal and a threat to nation while at the same time their labour was critical to the success of Canada's war effort and hence the making of the Canadian nation. Lisa Lowe has called the contradictory positioning of Asians in the United States a "double front" produced and managed by a "racialized and gendered anti-Asian discourse." As she states, the "double front" is posed as the "Asian threat and encroachment: on the one hand, as external rivals in overseas imperial war and global economy and, on the other, as a needed labor force for the domestic economy." ${ }^{32}$ In the war launched against Japanese Canadians through the Internment, the "double front" served to contain and discipline people within each site of incarceration, both through accusations that they were the enemy and through the work they had to perform to survive and enact their loyalty. While their labour was needed to support the war effort and the Canadian economy, this need and its coercive materializations were obscured by discourses presenting forced labour as lessening their "dependence" upon the government. The racialized spaces of Internment also depended, therefore, upon class constructions to present those inhabiting them as degenerate. White bourgeois subjects could operationalize these interlocking discourses and spatial distinctions to produce themselves as "respectable," independent, and hard-working Canadian citizens; their denial of their dependence upon Japanese Canadians both 
through the use of their labour and in the interrelational processes that produced their very selves as "respectable" and autonomous are indicative of the high stakes involved in not forgetting. To admit and remember these relations also means admitting how white bourgeois subject formation is dependent upon violence in the maintenance of domination.

Another tension produced through the complicated construction of the sites of incarceration is once again the difficulty in naming these spaces as imprisonment. The very names of these sites - work camps and sugar beet projects - actually serve to mask their very function as sites of incarceration. People were moved to these sites under the order of provincial, federal, and municipal governments, and were only allowed within these spaces to perform labour. As Foucault states, "Forced labour is a form of incarceration," 33 and I argue further that we must see the relationality of the spaces of enforced labour to the other incarceration sites and to the spaces from which people were forced to move, in order to see that people did not inhabit them by choice. We will see how these spatial interrelationships and their namings are struggled over by the women who were moved to sugar beet labour sites.

Two of the women I interviewed were moved to Manitoba farms with their immediate families. Esther was only three when they were moved and Margaret was fourteen. We must therefore remember that the memories of these farm spaces of incarceration are generated by one woman who was too young to work in the fields at the time and another who went to school and worked in the fields. What they do remember, from their younger perspectives, continues to reveal the exclusions experienced by those displaced outside of British Columbia and the losses suffered during these displacements.

Esther, who was three when she was forced to leave her home in New Westminster, explained that she doesn't remember leaving their home or the process of moving to Manitoba. She says she knew her family owned three boats and her father was able to sell them "before they were seized" 34 by the government. She also describes the boats as belonging to the male members of the family, one belonged to her father, the other two to her elder brothers. ${ }^{35}$ This gendered designation of property is also used by some of the other women and their daughters to describe the loss of familial possessions. for example, when boats or houses were confiscated by the government, men are often 
described as their owners. This gendered notion of ownership may affect the ways in which women describe their material losses and what they describe as being lost by them.

Esther describes her understanding of their move to Manitoba in this way:

[My father] sold the three boats and we weren't interned anywhere.

Apparently, there was another option. The option was go to work in the sugar beet fields in Manitoba or Alberta. ${ }^{36}$

When I asked Esther if she had to work on the farm, she replied that she was too young to work. But her mother had to work: weeding and picking in the beet fields, caring for the children, and cooking for the family. When I asked if her sisters worked in the field she replied:

Yes. Everybody worked. Everybody worked in the fields. It was hard work. Yes. It's amazing. I don't know how they adjusted.... And though seven years, I guess, in a person's life isn't very long, it must have been a long time for them. ${ }^{37}$

Esther situates herself in a family of seven children where she, being the youngest, was taken care of by her parents and older siblings. She minimizes the seven years she lived in Manitoba as a child relative to the seven years endured by the familial adults and older children in back-breaking work. In her interview, she often speaks of the hardships experienced by her parents and her elder siblings.

While the government considered that the earnings from the beet season were sufficient enough to "carry them through to next season," 38 and sustain them during winter, members of Esther's family had to work to support the family during this period. During the winter, Esther's elder sister took in sewing and her brothers worked in Ontario in the pulp mills.

Racism was encountered by her older brother when he quit school at the age of fourteen because he "ran into so much discrimination." 39 Despite the ongoing nationless posed by displacement and the racism encountered in each space, this same brother kept up his subscription to the Vancouver Sun. In resistance to his inability to attend the white school space, her brother devoured the contents of the Vancouver newspaper. It was her family's ability to keep abreast of government policies, perhaps in part through this newspaper, that Esther links to her father's informed decision to move the family back to Vancouver when the restrictions were finally lifted in 1949. 
Esther described how the Red River flooded twice while they were living in Manitoba. Their home was flooded and they had to move to higher ground. She emphasizes that it was other family members who had to deal with the difficulties imposed by their spatial restrictions "because somebody always looked after those kinds of things because of where I was in the family." 40

As is evidenced in previous testimonies, Esther re-members the people from whom her family was separated. She speaks to the relational losses experienced by her parents through her guarding of the possessions she inherited from them, photographs carried from British Columbia to Manitoba and back again. From Esther's testimony, one can deduce that her parents' lives were strongly connected to community. She explains. "in those days, they used to take a lot of pictures. I think it had to do with wanting to send photographs back to Japan. And in those photographs, you see gatherings of people standing on the steps of the Japanese Language School and the Buddhist Church. And those kinds of important functions that they had." ${ }^{\text {"dl }}$ Esther's parents had also served as baishaku-nin, or go-betweens, in introducing single men and women to each other. Among the photos carried to Manitoba were those of couples they had acted to unite. Of all the possessions they decided to carry with them, her parents chose these photographs. In this way the photographs become deeply symbolic of both the memory and the loss of community, relationships, and the roles they played within that community. I would also suggest that cherishing these photographs, these mnemonic records, was a form of resistance to the material dispossession as it occurred on so many levels. To this day, Esther continues to "carry" these "old photographs" with her each time she moves "from house to house." ${ }^{, 42}$

This relation-filled community must be contrasted to that of the "desolate place"43 in Manitoba to which they were sent, where were hired three or four other Japanese Canadian families to work on the sugar beet farms. Esther does say, however, that her family connected to other "ethnic families" in this area who were of German and Ukrainian origin. ${ }^{44}$ This re-constitution of self and family in relation to other marginalized communities is witnessed in Esther's comments that their friends were "ethnic people."4s

Another way in which Esther's mother tried to recreate her familial community while in Manitoba was by sending packages of food and clothing to her family in Japan. 
Esther's elder sister was designated the addresser of the parcels and she could easily recount the names of all the addressees. While all parcels and letters were subjected to censorship during the war, some from Esther's family arrived at their destinations. After the war, they received photographs of children wearing their clothing confirming the receipt of their gifts.

Another possession that Esther's mother carried with her were the ashes of her daughter who had died by drowning when they lived in New Westminster. In contrast to what she described as the boats belonging to the male members of the family, Esther clearly situates the relationship of ownership of these ashes and their care to her mother. As Esther explains: "my mother, being Buddhist, took this little box of ashes. It was in a cloth, all wrapped up in a cloth. And that box of ashes went from New Westminster to Manitoba." 46 While in Manitoba, another of Esther's sisters died from what was diagnosed as cancer. Esther states, "that was very sad.... And again, there are funeral pictures. She was only fourteen." ${ }^{47}$ Esther describes how her mother carried both boxes of her sisters' ashes back to New Westminster when they returned there in 1949:

They carried all of that. It's interesting. So that those children would not be left in Manitoba. That's how strong the family, you know, the group was. $^{48}$

Esther then shares with me a memory she had of visiting her sister's high school after her sister had died and the discovery she made there:

I always remember this sister that died...I remember going upstairs and seeing this book on a stand and I looked at it and opened it up and it was a gift from my father and mother to the school in memory of my sister. And it was this great big dictionary.... And they had made this donation. But, holy smokes, wow, you know, in those days, to make a donation like that. And so I thought, wow, that was pretty nice. ${ }^{49}$

Esther continues, "I haven't thought about that for years and years." ${ }^{50}$ Even in telling me of this memory, Esther recreates a constellation of family members who form a part of her memoryscape, witnesses to her re-membering. Her parents had not told her of this donation; however, she thinks she mentioned it to her sister. She also adds that she is not sure whether she has told her daughter about this gift. She explains why she thinks her parents didn't tell her about their gift in her sister's memory in this way: "people just never talked about a lot of things. And it was probably just to avoid the hurt." 51 
Yet the symbolism of the dictionary, full as it is of words and the possibilities for communication, "speaks" enormously of the loss of a child and parents' determination to make that loss visible in a white English school space. Even though their male child had been excluded from a space of schooling and they themselves were in these rural environs because of their expulsion from the nation space, their gift speaks of a resistance to this exclusion, marking the terrain of non-belonging with the presence of their loss. This loss would be marked for future classes of predominantly white students, saying "We were here, " forever begging the question, "Why?" and "How?" While some of the Internment literature constructs Japanese Canadians and the Issei in particular as "silent," I continue to look for the multiple ways in which they communicated their subjugated knowledges, including their understandings of the violence they experienced and the knowledge they continue to impart across time and space.

I would like to return here to Esther's comments at the beginning of her interview where she states, "we weren't interned anywhere." This delineation of being sent to the sugar beet farms of Manitoba as "not internment" is also something that arose in Margaret's interview. From my interchanges with them (and for other reasons previously discussed) I realize my own use of the term "Internment" is problematic. When I uttered this word in my interviews with women, I failed to tell them that I was using this overarching though inadequate term to describe the forced removals of all Japanese Canadians from the west coast.

My lexicon was challenged by Margaret when I asked her how the Internment had affected her. She responded, "Well, we never went to ghost towns, so I don't know what it's like. We came directly to Manitoba, so it wasn't like internment at all." 52 Margaret also told me she had gone on a tour of the B.C. interior camps and had been asked by other participants, "Where are you from?" "Nowhere," she replied, "I never was in the ghost towns." 53 She was then asked: "What made you come on this trip?" And while attending a conference on the expulsion from British Columbia, she failed to meet anyone else who had been sent to work on sugar beet farms in Alberta or Manitoba. What Margaret's comments point out to me is the fragmentation of the experience of the Internment and how our efforts to represent and commemorate it may in fact reproduce different fragmentary and exclusionary forms. ${ }^{54}$ I must also clarify here that it is not a 
unitary conceptualization of the Internment that I am seeking but rather I wish to illustrate how its fragmentation produced different, yet relational subjectivities.

Just as I have accepted the term "Internment" to be emblematic for something that I cannot entirely name, Margaret names her own experience as "not internment" to differentiate it from the interior prison camps. It is this context of the fragmented sites of incarceration and enforced labour, and the liberal discourses we have inherited to describe them that inform the ways in which we can speak and cannot speak about the violence of these displacements. Constituting herself within this inherited discourse, Margaret adds: "We came directly to Manitoba, so it wasn't like internment at all...I mean there was freedom. We could do whatever we wanted as long as we worked on the fields." working on the sugar beet farms is "not internment" because the farm is a different space than that of the B.C. prison camps, it must perforce be described as something else.

The discourse of equating the farm space with freedom is spatially produced through Margaret's comparison of the farm to the prison camps or what she calls the "ghost towns." The notion of the sugar beet farms or the prairies as a "free" site may also be influenced by a national discourse where Canada is imagined as an empty space, where the sprawling prairie farmlands offer the liberal subject the promise of freedom and equal rights through hard work. However, the Canadian imaginary is limited and exclusionary. Are Japanese Canadians ever thought of as having worked the prairie fields and being forced to work them? The coercive relations of this space of labour and the labour itself are forgotten when Japanese Canadians are removed from the narrative of who has built the nation and who is included when the nation is imagined.

As S. had struggled to name what the Tashme site was to her - it did not resemble the commonsense notion of the space of prison as she knew it - so Margaret is careful to delineate the difference between the interior prison camps and the farm to which she was sent, concluding that the latter could not spatially be "internment." She is careful to explain, "we were never in ghost towns, so we have no idea what life was like there. Our situation is a bit different, I think." 56

As I stated earlier, I see these uses of language as the careful negotiations of naming of what is impossible to name faced with the linguistic and discursive mechanisms for forgetting the violence promulgated by and through the Canadian state. 
In these attempts by women to specify the spatiality of violence, there is an awareness of how entire communities were displaced and confined in multiple ways.

The missing are not with us, but we will re-member them through the naming of the places in which we were not.

Margaret also situates herself in relation to people of her mother's age. She states, "anybody our age, we didn't really think it was too bad because we weren't old enough to appreciate what we had or how tough life was after the war started, being evacuated. So, I can't say that I had any really hard feelings except of course when we went to Winnipeg and were discriminated against. That was about the only time I could say we had hardship." ${ }^{57}$ Both age and position in the family constellation influenced the ways in which women re-member the incarcerations, forced labour, and displacements. These criteria, however, must not be used as deterministic of homogeneous experiences (everyone of the same age and birth order must have the same experience) but rather are only two factors out of innumerable ones influencing how women heterogeneously construct themselves in relation to and in re-membering this national violence.

It is clear from Margaret's testimony that what she earlier denotes as "freedom" was also extremely oppressive and restrictive. Her father had died when she was two and her family was headed by two women, her mother and paternal grandmother. She describes arriving in Manitoba, where they had to stay in an "animal shelter. The women had no privacy. It was just one big room. So, it must have been very hard for women." 58 From this central building, her family was moved to what she describes as a "two-room shack with a dirt floor."59 "That was the last straw, I think, for a lot of women," she adds.

She explains that they were only able to move to a prefabricated house after her "outspoken" brother complained about their living conditions to the government.

However, she explains the "prefab" wasn't much bigger than the shack, although it was divided into five rooms instead of two. She describes it in this way:

You only had room to walk into these rooms. And because there were seven of us, there was my mother and my grandmother, you know, it was very difficult.... And the winters there are very cold.... And we had to get water from the well. And the well would freeze in the winter because it was so cold. ${ }^{60}$ 
Margaret's description of the living conditions must be contrasted to that of a government report that described the "Japanese families" as "very fearful of the rigours" of winter, but concluded that "housing is adequate and no hardships from the weather will be experienced."61 Once again patronizing, government thetoric obfuscated the harsh conditions people were forced to endure. The Manitoba winters were severe and the coldest temperature recorded in the area during their first year was in January 1943 when the lowest temperature was -34 degrees Fahrenheit. ${ }^{62}$

Margaret walked a mile to school and described not being able to see the roads in the winter blizzards. In the summer, after school, she worked on the farm. The children would weed the beet fields and during the harvest, they would clean the beets, cut off the tops, and put them on a machine. "It was back-breaking work, because you're always bending down," she states. ${ }^{63}$ She also described how the entire family had to work in the field, "in the Prairies it was really hot. It was rough because even my grandmother was out in the field working...the families who went to the farms really had to work hard."6t

Margaret's family knew no one when they were moved to Manitoba. Two other Japanese Canadian families were later moved to the same area. Despite the fact that they lived "east of the Rockies," Margaret's family was asked to sign the Repatriation Survey. They decided to continue to live east rather than face deportation to Japan. Her grandmother's brother, however, signed to go to Japan through the Survey and was deported with his wife and their youngest daughter who was a year older than Margaret. She describes how her young second cousin became ill in Japan and how "life was so rough down there that she died within a couple of years." 6.5

Margaret situates herself within this extended constellation of familial and communal relations and concludes that for "women who had families and little. little children especially found it very hard. It was a pretty bad time for everybody, I think." 66 She concludes, "it was a tragic time."

The awareness of how much was lost by the first generation resonates through all of the interviews. This understanding of gender, class, physical ability, and age and the different responsibilities and hardships accorded through each interlocking discourse is thus profoundly conveyed through these testimonies. Margaret, for example, tells me that her paternal grandmother's family owned "a lot of property," property that was lost. She 
states, "I think it was very hard for her.... And then having to come out east when she had nothing. She didn't even have her own place. She had nothing to call her own or her family history or anything. ${ }^{.68}$ Margaret adds that she knew that it was difficult for both her grandmother and her mother and concludes, "they really had no place to call their own. I think that was the hardest part." Just as earlier Margaret described her grandmother's loss of "family things" as a monumental loss. here she characterizes the multiple displacements as producing the loss of "history." Margaret situates herself relationally to these elder women and states, "So, I can't see the kids suffering, not the kids so much as the parents."70

Margaret's analysis of the impact of the Internment upon her mother and grandmother emphasizes the violence of displacement and the "placelessness" experienced especially by these elders whose sense of place and the people who had shared that place was forever ruptured by the Internment. As May earlier stated. the displacements to various sites of incarceration left her feeling "out of place."

Families and communities were thus materially robbed of their sense of place, their historical connections to places, both to Canada and to Japan, through dispossession and displacement. The demonization of their connections to Japan, to extended family and Canadian family members visiting Japan who were not allowed to return to Canada after the war was declared, was also a part of this loss of history.

Margaret's family lived on the sugar beet farm for two years. Her brother then found a job in Winnipeg and moved the family into the city. "He felt we shouldn't live in those conditions," she states. " As we shall see, the exclusions from white spaces continued in this displacement to the city, as did all the other restrictions legislated by the state.

\section{Neys Hostel}

To facilitate the process of dispersal, hostels were set up by the federal government in Moose Jaw, Saskatchewan; Transcona, Manitoba; Neys, Hearst, Summerville, and Fingal, Ontario; and Farnham, Quebec. ${ }^{72}$ These hostels were significant sites marking what was for many the last time they lived "side by side" non-familial community members. As had been the case in all of the racialized spaces of incarceration, 
the hostels presented horrible conditions and were the source of painful memories. While all of the spaces of incarceration were pathologized ones, leaving them presented the coerced and contradictory predicament of being torn from members of one's community and family as the only way of being able to stay within the nation space. Japanese Canadians would have to negotiate the white spaces in which they would have to work, many without a community with which they could name the violence done to them. Dispersal ensured these separations, and the production of the forgetting of the violence from the moment the government enacted its repressive legislation continued throughout the dispersal process. Individuals would have to confront this ongoing production of forgetting, often explained as "ignorance," and the silence of the white subjects inhabiting the spaces into which they were forced to move.

From the hostels, people were forcibly dispersed to different towns and cities. By the end of 1944, the federal government had also established "Japanese Division Placement Offices" in Lethbridge, Winnipeg, Fort William, Toronto, and Montreal. In 1946, placement offices were also set up in Moose Jaw and Ottawa. ${ }^{73}$ The mapping of these sites of forced dispersal illustrates how the federal government envisioned the continued displacement of people remaining in the sites of incarceration and forced labour.

According to Joseph Fry, Neys was established in 1941 as an internment camp for German prisoners-of-war. Neys, located on the north shore of Lake Superior, proved to be what Fry calls a "formidable POW camp" due to the "inhospitable wildemess beyond the barbed wire fences and guard towers."74 In April 1946, the "POW" camp became a "hostel" for several hundred Japanese Canadians forced to move from British Columbia to Ontario. Through this "conversion," we see how an untransformed space of incarceration is linguistically translated from a "POW camp" into a "hostel."

Two women I interviewed described the Neys Hostel. Kazuko described Neys as being comparable to Hastings Park. She characterized her experience in this way:

...when it's lunch time, you just hold your plate and march. It was just like a prison, I'm telling you. You couldn't go anywhere. You just stayed in the one place all the time. They wouldn't let you go out. ${ }^{75}$ 
Kazuko chooses here the word "prison" to delineate the space of Neys. The spatial setiing of the prisoner-of-war camp turned "hostel" is semantically linked to the spatial notion of prison, with its four walls, as compared to the spatially and discursively obfuscated sites of the sans walls B.C. interior prison camps and the sugar beet farms. What is unclear, though alluded to in her testimony, is how white enforcers in each site constituted themselves through their treatment of the inmates. For example, Kazuko's use of the term "march" in her description of lining up for food connotes a militaristicallyenforced environment. One wonders who was giving the marching orders in this site? And how does their constitution of the site as a "hostel" disguise these relations of power and violence?

Yoshiko described Neys as "that camp by Lake Superior. That was a dreadful place." ${ }^{76}$ For Yoshiko, Neys was "the worst of the journey. [A] terrible place.... That was the camp where you were placed before they could find some place for you to go.... Dreadful, dreadful place." 77

The use of the word hostel is another example of how spaces were euphemistically named to obscure the relations that created them. How can we as a community come to grips with what must be a painful ambivalence for many people who remember these last years living with other Japanese Canadians as occurring in horrendous conditions under surveillance and the ongoing experience of loss? Rather than concluding that their testimonies unitarily construct subjects who "accepted" the violence. how might we challenge our own forgetting of the violence and ask how this forgetting is socially produced? What happened to the non-Japanese Canadians who gave the marching orders at Neys? How can we begin to interrogate the silence of all the white witnesses to the mass expulsion, incarceration, and displacement of Japanese Canadians?

\section{Domestic Labour During the Internment and the Dispersal}

Women's labour during the Internment and dispersal not only comprised giving birth, cooking with few supplies, and cleaning their own meagre dwellings but they were also hired to do domestic service. I focus upon the space of domestic service in this section because five of the eleven women I interviewed, May, Evelyn, Hard, S., and Kazuko, engaged in domestic service for families other than their own after they were 
removed from their B.C. homes. As was seen in the section above, Margaret's sister moved to Winnipeg in the winter to do domestic work, leaving her family on the sugar beet farm. She states: "[My sister] had to live with the white families in order to do this." ${ }^{\text {"78 }}$ While my work cannot achieve an in-depth discussion of the spatialized processes of dispersal and their relationship to domestic work placements, I will briefly give some examples of the spatial constitution of domestic work and how it was a process of constructing racialized gender relations. I emphasize, however, that much more work needs to be done in further analyzing this particular contact zone with white bourgeois employers.

It must also be remembered that domestic service was not a new occupation for Japanese Canadians. Women and men, upon immigration, were engaged in domestic service. ${ }^{79}$ In my study, Aya described how she had worked in domestic service prior to her marriage, and two other women indicated that their mothers had worked in domestic service. May's mother worked for the family of a white owner of a major B.C. corporation after the death of her second husband. Hard's mother worked as a "nurse, maid, cook" in Victoria before they moved to Vancouver. ${ }^{80}$

Some women were hired by prison camp personnel and the RCMP in the sites of incarceration. Yoshiko reported that in Slocan her "girlfriend's mother cleaned house for the "Mounted Police" in another section of town." 81 She also described how this section of town housed the white people and when she went with her friend to take something to her mother at her workplace, she saw "a little girl in the house about our age. And we never saw her around. So there must have been another way to educate non-Japanese." Thus even in the racialized space of the prison camps, a white space was carved out and kept pristine, in part, through the work of Japanese Canadian women. In this way, the white enforcers could continue to live separately and reconstitute a white space and its superior entitlements in the face of the reality of the racialized space inhabited by people torn from their own homes. Privilege and the mythology of "respectability" were thus also secured for white subjects through their proximity to the pathologized space and even more closely through contact with the domestic servants engaged to maintain their homes as "clean and civilized." 83 As John Fletcher Clews Harrison states of the construction of domestic work in late nineteenth century England, "With one group, 
domestic servants, the middle class stood in a very special and intimate relationship: the one fact played an essential role in defining the identity of the other." 84

Through its enforced work placements, the government drew upon the immigration discourses delineating that racialized women and men labour in the lowest categories of work while treating them as outsiders and disentitling them to the rights of citizenship. The very language of the forced displacements reflects how the nation continued to renarrate Japanese Canadian citizens who were formerly residents of the B.C. west coast as "foreigners." For example, when a ban was placed on people moving to Toronto, Mayor Saunders referred to this as a halting of "further immigration." 85

Through government narrations of the Internment, we see how the forced dispersal of Japanese Canadians from British Columbia came to be tied to the performance of loyalty and independence. The terminology of "self-support" was not only used to describe people in the spaces of the "self-support" communities. As the government coerced more and more people into taking jobs "east of the Rockies," those who were earning an income were called "self-supporting" individuals and this distinction was used to negatively construct people who were not being paid for their labour, for example, mothers in the prison camps, as dependent on the government. The government used the argument that work would ensure the independence of those unemployed to legitimize forced dispersal. In this way, the government became the paternal benefactor releasing its charges to "freedom," once again producing a forgetting of the violence of dispossession and imposed placelessness. It is this promise of freedom that is so tied up with the liberal notion of citizenship. Those who took up employment in eastern locations were also constituted as more "Canadian" than those who remained in the prison camps. As a BCSC report stated: "Only the very young and extremely Canadianized succumbed to the persuasion to accept employment east of the Rockies."86 In this way, discourses of liberal humanism interlock with those of capitalism to produce work as "freedom" and part of the performance of loyalty. However, the attainment of citizenship is always indeterminate for racialized subjects in a white-dominated nation and the threat of the mark of "disloyalty" underpins how we situate ourselves in relation to discourses of domination. 
The movement of women into domestic work situations in Ontario and Quebec began as early as 1942 , when 100 women were reported as receiving "special permits" to leave British Columbia. ${ }^{87}$ Where women moved east to take up domestic positions, what is obfuscated if we talk of their "choosing" to move are the material needs that necessitated women moving to eastern provinces and also the threat of deportation for those who did not move after the Repatriation Survey was taken in $1945 .^{88}$ The liberal discourse of "choice" also renders invisible the government's own en-gendering relations through the spacialization of incarceration. With many men removed from the spaces inhabited by women and children, women were largely responsible for childcare and were not eligible for domestic service work designed for women with no dependents.

Paradoxically, the women upon whom depended over 5,000 incarcerated children. ${ }^{89}$ were characterized as "dependent" by the government and "less Canadianized."

What also gets forgotten through the discourse of "choice" is the violence involved in the coercive measures of forced dispersal to domestic labour positions and the separation of young women from their families and friends. A government report made light of these separations stating, "The Jews did not face the Red Sea with greater trepidation than the first small group of Japanese dc mestics who entrained for London, Ontario." 90 This depiction of women's resistance to leaving their families as a sign of a "backward" essentialized characteristic of "Japanese" families will be further examined in the next chapter. The discourse of women "choosing" to take jobs in domestic service also obfuscates how labour shortages determined the allowability of some Japanese Canadian women and men to enter white spaces, in this case, white homes, even when they were excluded from becoming permanent residents of the cities or towns in which these homes were situated. This was witnessed in the case of Evelyn who laboured in a Lillooet home while being excluded from living with her family in the town. Another example of this prohibition on residency was the province of Alberta's agreement with the federal government stating people would be removed as "soon as the emergency ceases" or "six months after the end of the war if the province so requested." Spatial separations were thus preserved at the same time as white employers profited from the contact with Japanese Canadian domestic workers. 
Forced to move from homes of their own, Japanese Canadians were hired to clean the houses of the white Canadian nation. Gender constructed labourers in particular ways and it is important to note that in the area of domestic service both Japanese Canadian women and men were deemed as appropriate workers. Historically this has been the case for racialized men whose work options were extremely limited and who thus were compelled to take jobs in a feminized work sector. ${ }^{92}$ More research is needed in this area to see if domestic service jobs held by men differed in content or wages as compared to those held by women.

Thus en-gendering discourses were also applied to men through processes of incarceration and displacement. Racializing and feminizing Japanese Canadian men is part of a discursive process of constituting a masculinity different from that of white bourgeois heterosexual men. In order to legitimate the forced movement of men to disparate social spaces (POW camps, farms, work camps, the white family home, etc.) and the work imposed upon them in these spaces, various en-gendering discourses had to be mobilized.

There is evidence, however, that the federal government particularly targeted the women in the prison camps to take up domestic service positions in response to the flood of requests received by the Department of Labour and by individual politicians. ${ }^{93}$ As women were dispersed from the prison camps and sugar beet work, domestic service was one area in which they had to seek employment. As my previous research has indicated, this pressure, as in many of the Internment-related displacements parading as "choices." was largely coercive in a situation where financial need was desperate and the Repatriation Survey had imposed the need to find work for those forced to move east of British Columbia. ${ }^{94}$

Anne McClintock reveals that in late nineteenth century England, "no selfrespecting middle- or upper-middle class household could afford not to keep at least one female servant."95 She quotes Hobsbawm who discussed the critical definitional role of domestic service when he stated "The widest definition of the middle class... was that of keeping domestic servants." 96 Japanese Canadian women's roles as domestic servants must be viewed within this context of white employers constituting themselves as Bourgeois subjects in relation to their racialized employees. Hiring racialized women to 
do domestic work produces a situation where the white woman employer can reproduce a particular white bourgeois femininity deserving of time to "choose" her activities and not be sullied by domestic labour. Even in the cases where the white female employer still had to undertake some of the domestic work and childcare functions, the fact that at least one servant was engaged met a certain minimum for white women desiring "membership in the 'respectable' class." ${ }^{97}$ And as my earlier research indicates, it was not only married white women and men who sought the services of Japanese Canadian domestic workers, but single white women also wrote to the government expressing their need for such assistance. One woman, in particular, argued that she should not have to pay " $\$ 30$ a month for domestic help, when she knew of families who had employed 'Japanese maids' at the same wage." 98

It was through domestic work that May moved to Toronto in 1945. The United Church missionaries in Lemon Creek referred her to her first "housegirl" position in Toronto. When I asked her about how she felt leaving Slocan, she described how she was "quite excited.... I was worried actually about my mother and sister because my mother still was not well. But I felt on the one hand I was breaking out." 99

The domestic service job to which she was sent was a live-in position with a Jewish family. By day she went to high school. Every weekday after school, she cleaned the employers' home until 8 p.m. and then studied for the next day's classes. She worked all day Saturday and most of the day on Sunday until late afternoon and then was able to go to church at night. She worked "seven days a week for three dollars a week." 100 She also did childcare at night for the employers' child. She worked at this home for one year.

Two weeks after beginning school in Toronto, May was called to the Principal's office and told she had to leave the school. The reason given to her was that she did not have a "taxpaying family living in Toronto." 101 She was told she would therefore have to be a "fee-paying student." This, of course, meant that she could not continue her education because she could not afford these fees. This announcement "just devastated me," she adds. ${ }^{102}$

May reports that a school trustee eventually assisted her in contesting this decision and she was allowed to attend the high school without paying fees. Yet her encounter with this additional exclusionary practice gives a sense of some of the difficulties 
Japanese Canadians encountered upon moving to Toronto and the spaces from which they continued to be excluded.

May began Teachers' College, but after two months she had to leave for financial reasons. In order to support her mother and her sister who were in New Denver, she got a full-time job and continued to do domestic work. She hoped to return to Teachers' College one day because she wanted to be a teacher. She told me "I wanted to go to school more" and "one of my great regrets" was not completing Normal School [Teachers' College]. ${ }^{103}$

May changed domestic jobs during this period looking for better positions, doing "a lot of home-hopping." She took live-in jobs because "it's all I could afford. The jobs were paying me around seventeen doll ars a week." ${ }^{04}$ She states, "It was such a mixed-up time of my life: trying to get a job, save up, go to school, finding I couldn't go to school and then having to find another job again." ${ }^{105}$ May struggled to earn a living, working at an office and continuing her live-in domestic work. She sent money to her mother and sister in New Denver and eventually supported their move to Toronto. When her mother was moved to Toronto, a Japanese Canadian woman helped her get a job in a laundry. May states, "My poor mother hadn't worked in years and years. It must have been horrendous for her." 106 May explained that she and her husband had difficulty supporting their families as they were displaced to Toronto and her mother was "determined to try" to contribute financially. ${ }^{107}$

May described what it was like to be in Toronto when the atomic bomb was used against the people of Hiroshima and Nagasaki by the United States. She attended a church service where the minister condemned the bombing. She describes her complex reaction in this way:

...in August The Bomb had fallen in Japan. And VJ Day had been declared. I didn't know whether to feel good or awful. I was still feeling very unsure of my position. Coming from the camps where I know we were not liked by the "outside" somewhere. And coming and hearing a United Church Minister stand up for the people that looked like me who had been bombed, I didn't know whether everybody felt that way or what. ${ }^{108}$

May also uses the metaphor of the "outside" space, as had earlier S., "where we were not liked." Being confronted by this "outside," yet still "outsiders" to it, was the 
social position of Japanese Canadians and part of the uncertainty that continued over numerous spatial displacements.

May was married in Toronto and in the 1950s she moved with her husband to B.C. to help his parents with a business they were trying to establish with other Japanese Canadians. Spatial displacement continued as people tried to make a living after the incarcerations and re-build communities. These plans to re-build a community life were again disrupted when there was a fire that destroyed their place of work. After this loss, May's family moved back to Toronto.

S. and her brother also moved to Toronto by taking domestic service positions. S.'s brother moved first and worked as a "schoolboy" while attending school. She describes his employers as "inviting" her to join him in this employment. She moved to Toronto where she looked after the employers' child while completing grade thirteen. She describes how she was able to "do well in those grade thirteen exams, which was really something." 109 S. eventually moved from Toronto and resides in a town on the Prairies.

Hard also took a job in domestic service in Northern Ontario. She recounted to me how "there were a lot of domestic jobs coming out of the ghost towns, to come east." 110 She said she knew of other women who had taken jobs in St. Thomas at Alma College where they exchanged their labour for an education. "I know a lot of friends who did that," she states. ${ }^{11}$ Hard was married in Northern Ontario and described being there at the end of the war with Japan. She states, 'Til then, we were 'Japs.' You know what I mean? We kept to ourselves. There were more Europeans [in the town]: Italians and Ukrainians, Polish, Swedish, so they were good to us.... All our neighbours were hakujin." 112 She describes being out for a walk with her partner and their baby when the armistice was announced, "everybody went wild. Even though I felt funny, we weren't scared." ${ }^{113}$ Hard later moved to Toronto with her family.

Although Kazuko was very anxious to leave Rosebery, she had to leave behind the friends she had made. Kazuko left Rosebery by herself to take a job in southern Ontario. She states she wanted to "get out of" Rosebery and found a domestic job by looking in the newspaper. When she arrived at the train station, there was no one to meet her. "That was a terrible experience for me," she states, "coming in the dark and not knowing where it was." "It It was around 2 a.m. when her employers came to pick her up. 
Kazuko worked as a housekeeper in the home of a white doctor and his wife who was a nurse. There were other Japanese Canadians employed by the same family. As she states, "there was a chauffeur, he was Japanese. And also they had another maid there who was Japanese." 115

Kazuko described having to work "long hours," fifteen hours a day. The doctor would arrive home late and he and his partner would have cocktails and dinner. Kazuko lived with the family and did the cooking and cleaning. There were four children in the household who later attended private school in Toronto: the two girls went to Bishop Strachan and the boys went to Upper Canada College. In the privatized space of the home, paid domestic work is a critical social process in the construction of class and racial differences. Little attention has been paid to the contribution of Japanese Canadian women and men through their labouring as domestic workers. Very little work has been done to examine who were the employers of these workers and workers in other industries and the benefits they accrued from their labour. While Kazuko's labour was used to reproduce the family for whom she worked, her own family was separated and displaced through the Internment.

Kazuko's family was moved to Toronto and she went to visit them once a week on her day off. She was not able to join her family until she could secure a job in the city. This separation from her family continued for the ten years she worked for these same employers. Although other Japanese Canadians moved into the area, their separation was ensured by geography. "The houses were too far to visit," she states. ${ }^{16}$ Eventually, the Japanese Canadian woman with whom she worked put her in touch with the woman's father who was working in Toronto at a factory. Kazuko was willing to do anything to be able to move to Toronto. After securing a job offer at the factory, she was able move. She described how her former employer later moved to Toronto to live in a seniors' apartment. Kazuko once again did domestic work for her and did so until her employer died. At this time, Kazuko was 67.

When Margaret's family moved from the sugar beet farm to Winnipeg, her sister had to work in domestic service. She states, "That was about the only thing my sister or any Japanese girls were able to do, was housekeeping." 117 Her brother went to work in a logging camp. 
Margaret also talked about other women who worked as domestics after leaving the "ghost towns." Every Sunday, her family would invite women for dinner on their one day off. She explains:

They had no family. They came out on their own. So they used to come to our place.... It was being together with other...their own kind. So, it was just something we did. Every Sunday. They came, so it was a gay time. For us and for them, you know, they really enjoyed coming to our place. ${ }^{18}$

Margaret's family organized the space of home in Winnipeg to welcome other Japanese Canadians forcibly dispersed from various sites of incarceration. Reconstituting themselves in this way provided a site of resistance in the face of continuing exclusions. An example of this exclusion was noted by Margaret who described how the white residents of the street where they rented their first house circulated a petition, "saying they didn't want any 'Jap' living there."119 This fact was later confessed to them by their neighbour.

Margaret also noted how they were stared at on buses and were not allowed to eat in any restaurants, except for one "Chinese restaurant." She reported, however, that they could not eat in other restaurants, including those owned by Chinese Canadians. There was also only one bowling alley that would allow Japanese Canadians as patrons and it was a Jewish-owned business. "So, of course, they got a lot of business for years because they were the only ones who accepted us," she explained. ${ }^{120}$ She also continued to eat at that same restaurant whenever she visited Winnipeg and regretted that it had recently closed. Margaret concludes, "my feeling is Winnipeg was kind of rough for the older generation." 121

Although some women reported developing an attachment to their employers through domestic service placements, what I wish to emphasize is how these relations between white employers and Japanese Canadian domestic workers also obfuscated the violence of the Internment and dispersal policy. Abigail Bakan and Daiva Stasiulis have described how employers who discursively constitute domestic workers as "quasi-family" or "family" members "mask their actual subordinate status and position in their employer's household." 122 What is also profoundly disturbing about the coercive nature of the dispersal policy, which resulted in some women having to work as domestics, is that women had to leave their own families and other sources of emotional support in taking 
up work that is critical in the production of the space of the white bourgeois home and its concomitant white bourgeois family formation.

\section{Displacement Continues}

In 1946, Aya finally rejoined her husband, her mother, and her brothers in the town to which her mother and brothers had been sent to work on a sugar beet farm. She describes how the government was "scatter[ing] everybody out there. But I said I wanted to go to Manitoba, where my mother was." ${ }^{123}$ Her husband found work on a farm and they later moved to northern Manitoba when her husband and brothers were employed in construction. When these jobs "slowed down," her mother and brothers moved to Winnipeg.

Aya's final move was in 1954 to the city in which she now resides. She moved in order to be closer to her children who, as they had completed high school, needed to move to a city in order to further their education and find work.

Aya's husband developed a heart condition, ill health that she attributes to his working hard on construction. After they moved, Aya and her daughters supported the family. Aya worked in a factory she described as owned by Jewish people. She makes a distinction between the jobs women of her age were able to get and those obtained by younger women who had more education in this way, "So the women, they all went into the sewing factories. And the younger girls...they went to business college and got secretary work. But people like myself and around that age, we all went to sewing factories." 124 She describes Manitoba as a place where Japanese Canadians were all scattered and they lived with people who were Ukrainian, German, Italian, and Jewish.

Louise, Aya's daughter, remembers her mother arguing with government officials in Tashme about the destination to which they were to be sent. The government wanted to send them to Moose Jaw, but her mother insisted they would go to join Louise's grandmother.

When they moved to Manitoba, Louise saw her father again after four years absence. She described feeling that her father "was actually a stranger...it took awhile to get familiar with my dad. But once we were [together] we just became a normal family."'25 
It was only upon reuniting with her father that her mother found out why her father had been incarcerated in the Angler prisoner-of-war camp. Louise remembers her father "always tell[ing] a story about" his imprisonment:

My father was sent on a road gang to Ontario, to mend roads and all that.... My mother was pregnant when we left Steveston. When she was going to have her baby, she sent word to my father that the baby was due and my father hopped on a train and he said to one of the fellows working with him that he was going to his wife in Greenwood and to let the Mounties know because actually you're supposed to get a pass from them. And he didn't. He just went on the train and the fellow he was working with forgot to tell the Mounties. So he was caught on the train without a pass. So, they immediately shipped him to Angler in Northern Ontario. So he spent the rest of the war years up in Angler. So my mom was left with the four kids in Greenwood. ${ }^{126}$

Louise's recounting of her father's story reveals how people had to wait years to find out what had happened to their family members and friends. And as Kazuko indicated in Chapter Five, some people never found out what happened to other familial members. Louise's testimony also indicates how people in different ways attempted to rejoin their families and were prevented from doing so. Her testimony also reconstructs the family space as one where memories of the incarceration are handed down to children, something I will examine further in Chapter Eight.

There were other Japanese Canadians in the town to which Louise's family moved, but they all eventually moved to Winnipeg, leaving their family alone. She states, "after that we sort of lost all contact with Japanese people. So when I was growing up I lost my Japanese [language]." 127 She remembers that her grandmother moved to Winnipeg when she was in grade six or seven and they "travell[ed] a lot to Winnipeg" to see her. ${ }^{128}$ Her elder sister moved to Winnipeg to continue her schooling after high school and lived with their grandmother. Louise followed after deciding to attend business college in Winnipeg. Her parents moved to Winnipeg shortly thereafter.

In Winnipeg, Louise found it "awkward" being with other Japanese Canadians because as she states, "I hadn't associated with Japanese people."129 She eventually moved to Toronto, while her mother remained in Winnipeg.

Ann's family stayed in a hostel in southern Ontario before being moved to Chatham. The first job held by her husband was on a dairy farm. A month later he moved 
to a job at a rendering plant because the farm work didn't allow him to "see [his] family." 130 The milking times took him away from the hours where his children were at home. Ann's family later moved to Toronto where both she and her husband worked until retirement.

Esther's family moved back to British Columbia after the restrictions were lifted in 1949. As she states, "all [my father] wanted to do was to go back."13! Esther's experience differs from that of most Japanese Canadians in that her family returned to the home space they had been forced to abandon during the years they were displaced. They moved back to the float house on which they had lived prior to the expuision. A Polish Canadian man from a neighbouring float house had watched their possessions and they were intact. Esther remembers "Japanese dolls that somebody had given me...were still there." 332 She describes how pansies her brother had planted before their leaving had reseeded and were blooming and "he was shocked when he saw those flowers. He broke down and cried."133

After the restrictions were lifted, Evelyn moved to Vancouver to attend school. Her family later left Lillooet to return to the coast. She described how her maternal grandparents were "older" when she saw them. "They left at the prime of their lives."134 She also saw that it was a "struggle" for her father to tell her grandfather that he could not fish and be a buyer of fish as he had before the Intermment. Her grandfather, however, continued to fish and one of his sons was encouraged to fish with him. Evelyn realizes that her father was able to return to fishing as compared to most of the men whose boats were "confiscated." She describes how her father's employer, who had bought his boat before they were removed from the coast, assisted her father in building another boat when they returned to Vancouver. While Evelyn is careful to acknowledge that her family received assistance in returning to British Columbia, her testimony also illustrates how white people who "assisted" were witnesses to their expulsion, dispossession, and multiple displacements.

From Neys, Yoshiko's family was moved twice to two different towns in northern Ontario. As an adult, she later moved to British Columbia. Her mother still resides in the northern Ontario town to which they were sent after being incarcerated in Slocan. 
While white bourgeois women who were engaged in paid labour during World War II were encouraged to return to the home to allow for full employment of returning white veterans in the post-war period, ${ }^{135}$ racialized women, including Japanese Canadian women, continued to work out of necessity in areas such as domestic service. The "shortage" of domestic workers experienced during the war continued well into the postwar period. ${ }^{136}$ Even though people were being dispersed into white communities, the social spaces of work continued to demarcate separate and racialized spaces for Japanese Canadians, reproducing the notion of their "foreignness" at the same time as profit was acquired through their labour.

As Japanese Canadians were dispersed in the post-Internment period. their old spaces of community in British Columbia were marked white through the sale or gift of their properties. One horrendous example of how this whitewashing of the land occurred was when farms owned by Japanese Canadians and the profits made from these farms were confiscated through the Veterans' Land Act. On 23 June 1943, 769 farms and $\$ 43,000$ income from the farms were granted to the Veterans' Land Act Board. ${ }^{137}$ The farms were slated for use by returning veterans, although no Japanese Canadian veteran was included in this reward for patriotism. The normalization of this process: the 22,000 Japanese Canadians removed from their homes and the people. predominantly white. occupying their former spaces of home, farm, school, church. logging camps... using their cars, equipment, boats, radios, musical instruments...spatially marks the terrain of British Columbia and is a clear cartography of how violence secured entitlement to the Canadian nation. So, too, is the normalization of the appearances of dispersed Japanese Canadians in towns and cities from British Columbia to Quebec, and the multiple uses of their labour through this process. As white people took over spaces formerly owned and occupied by Japanese Canadians, Japanese Canadians had to contend with dispossession and shifting placelessness, and attempt to reconstitute themselves in spaces where dispersal meant a final separation from some family members, old friends, and communities. Continually marking the multi-generations who have lived in these spaces of dispersal as from "Japan" or elsewhere in Asia is part of the ongoing production of us as foreign and outside of the nation, and also obscures the Canadian spaces from whence we came and were/are excluded, and the violence that spawns our displacement. 
In ending this chapter, I articulate perhaps a false sense of closure in narrating where women eventually resided after their displacement from their homes in British Columbia. This project does not undertake an examination of these spaces nor the struggles that these women continued to confront in reconstituting themselves, their families, and communities. Much is untold and I would emphasize that much of what happened during the Internment is untellable. The reader may have many questions about the details missing from my narrativization of the spaces of incarceration and displacement. While I have been selective in choosing what parts of the testimonies I shared, I also emphasize that survivors too live with the gaps in what is known about the Internment, its complex construction, its violence. The unknown and the unknowable. perhaps most apparent through the absence of those we no longer know and those of whose fates we know not about, are thus emblematic of the violence done to our community.

\section{Conclusion}

In this chapter I have continued to map the spaces of Internment and dispersal through an examination of one "Self-Support" community, the sugar beet projects, and some of the spaces of domestic service. I have illustrated how class was an interlocking discourse with race and gender in the production of these spaces.

What I am insisting on in my discussion of the spaces of Internment is not only were they were constructed so as to divide Japanese Canadian subjects along axes of domination and subordination, but also that these subject positions were always formed in relation to a hegemonic white bourgeois subjectivity. I am, however, aware that there are contradictions and complexities yet to be revealed to me as I continue this work. It is the very contradictions and complexities inherent in the interlocking of systems of domination that make them extremely difficult to unpack and resist. This complicated nexus of social relations of power also makes the experience and effects of the Internment extremely difficult to articulate. What I must emphasize is the need to see these systems as relational and these relations must ever be complexified through further investigation and analysis. Establishing the spaces of incarceration and forced labour called upon and reinscribed these systems of domination. This spatial arrangement not only delineated 
sites of incarceration and expulsion but it also served to map the cartography of Canadian citizenship and nation.

Establishing these spaces of exclusion produced violence of enormous consequence. Chapters Five and Six demonstrate the ways in which relationships and communities were ruptured, displaced, and destroyed. I have been unable to attend to other effects of the Internment in detail and further research is needed so that these effects may also be acknowledged and remembered. In relation to the violence of the Internment, heterogeneous subjects and heterogeneous responses were constituted. The violence inherent in the Internment, a violence that I have only barely begun to understand through the testimonies of these eleven women, is also a violence profoundly masked through discursive forgettings mobilized by both beneficiary witnesses to the violence as well as subsequent beneficiary generations whose dominance has been secured through such violence. In the next chapter, I seek to retrace some of the mappings of the expulsion from British Columbia through an interrogation of the measures taken by the government and citizens in securing the one hundred-mile coastal area. I will also interrogate the discourse of the family produced through the Internment and end with a discussion of the subject reconstructed through interpretations of survivor testimonies.

\section{Endnotes: Chapter Six}

1. Lowe, Immigrant Acts, p.57.

2. See Soja's analysis of the difficulty in writing about the simultaneity of spatial geographies through a "linear flow of sentential statements." Soja, Postmodern Geographies, p.2. Razack emphasizes how the linearity of writing also makes it difficult to describe and understand systems of oppression as operating simultaneously. Razack, "Race, Space, and Prostitution," p.355.

3. Sunahara, The Politics of Racism, p.65, p.78.

4. Canada, BCSC, Removal, p.11.

5. Ibid.

6. NA, RG 36/27, vol.1, file 17, "Distribution of Japanese," "Japanese Movement Pacific Coast" (Period ending October 31, 1942), p.4.

7. Interview with Evelyn, p.28. 
8. Ibid.

9. Ibid., p.29.

10. Sunahara, The Politics of Racism, p.65.

11. Interview with Evelyn, p.34.

12. Ibid., p.32.

13. Ibid., p.58.

14. Ibid., p.34.

15. Ibid., p.35.

16. Ibid., pp.58-59.

17. Ibid., p.44-45.

18. bid., p.77.

19. Ibid., p.72.

20. BCSC, Removal, p.19.

21. Ibid.

22. Ibid., p.10.

23. Ibid.

24. Ibid.

25. Only men were sent to Ontario because the farmers there were "not in a position to house families." The farmers of the Sugar Refinery Company later "gave these men credit for helping to save the Ontario sugar beet crop." NA, RG 36/27, vol. 1, file 17 . "Distribution of Japanese," "Japanese Movement - Pacific Coast" (Period ending October 31,1942$)$, p.3.

26. NA, RG 36/27, vol. 1, file 17, "Distribution of Japanese," "Japanese Movement Pacific Coast" (Period ending October 31, 1942), p.4.

27. BCSC, Removal, p.11.

28. Ibid., emphasis added.

29. See Soja's analysis of the relationship between capitalism and spatiality, Postmodern Geographies, p. 126. 
30. More research is needed to examine how work was constituted within the prison camps. Little is known about the work ferformed by Japanese Canadians in these spaces of incarceration.

31. Lowe, Immigrant Acts, p.102.

32. Ibid.

33. Foucault, Discipline, p.115.

34. Interview with Esther, p.29.

35. Ibid., p.17.

36. Ibid., pp.28-29.

37. Ibid., pp.43-44.

38. NA, RG 36/27, vol.1, file 17, "Distribution of Japanese." "Japanese Movement Pacific Coast" (Period ending October 31, 1942), p.2.

39. Interview with Esther, p.45.

40. Ibid., p.49.

41. Ibid., p.7.

42. Ibid.

43. Ibid., p.50.

44. Ibid., p.32.

45. Ibid., p.57.

46. Ibid., p.35.

47. Ibid., p.34.

48. Ibid., pp.35-36.

49. Ibid., pp.46-47.

50. Ibid., p.47.

51. ㅁid.

52. Interview with Margaret, p.71. 
53. Ibid., p.85.

54. Since interviewing Margaret, there was held a commemoration of the Fiftieth Anniversary of the Manitoba Japanese Canadian Citizens Association in August 1996. "Reunion 1996," was held in Winnipeg and presented various workshops and panels, including discussions of the forced displacement of people to Manitoba during the 1940s. See also Manitoba Japanese Canadian Citizens' Association, The History of Japanese Canadians in Manitoba, (Winnipeg: Manitoba Japanese Canadian Citizens' Association, 1996).

55. Interview with Margaret, p.71. My emphasis.

56. Ibid., p.79.

57. $\underline{\text { bid., p.71. }}$

58. Ibid., p. 101 .

59. Ibid., p.102.

60. Ibid., pp.35-36.

61. NA, RG 36/27, vol. 1, file 17, "Distribution of Japanese," “Japanese Movement Pacific Coast" (Period ending October 31, 1942), p.2.

62. Canada, Department of Transport, Meteorological Division, Monthly Record Observations in Canada and Newfoundland, January 1943 (Toronto: 1943), p. 13.

63. Interview with Margaret, p.38. Even the government acknowledged that the "topping" of the beets was a "very heavy job." NA, RG 36/27, vol.1, file 17, "Distribution of Japanese," “Japanese Movement - Pacific Coast" (Period ending October 31, 1942), p.2.

64. Interview with Margaret, p.37.

65. Ibid., p.49.

66. Ibid., p.91.

67. Ibid., p.44.

68. Ibid., p.73.

69. Ibid., p.75.

70. ㅌbid., p.75.

71. Ibid., p.35.

72. Sunahara, The Politics of Racism, p.141. 
73. Canada, Department of Labour, Re-Establishment, p. 16.

74. Fry, “Omoide Garden,” n.p.

75. Interview with Kazuko, p.14.

76. Interview with Yoshiko, p.23.

77. Ibid., p.60.

78. Interview with Margaret, p.41.

79. Evelyn Nakano Glenn's ground-breaking work analyzes the relationship of Japanese American women to paid domestic work in her Issei, Nisei. War Bride. See, also, Valerie Matsumoto's findings in the pre-internment community of Cortez, California, that "the majority of women did domestic work." In Matsumoto, Farming the Home Place, p.83. The relationship of Japanese Canadian women to paid domestic work has largely been unexamined in the Canadian literature.

80. Interview with Hard, p.3. See, also, interview with Mrs. Ellen Enomoto, Special Collections and University Archives Division, University of British Columbia Library, UBC Aural History Transcripts, 76-1, Mrs. Ellen Enemoto, 16 May 1972, p.7, for a description of how her mother did "housework... in English households" in Vancouver.

81. Interview with Yoshiko, p.27.

82. Ibid.

83. Razack, "Race, Space and Prostitution," p.363.

84. John Fletcher Clews Harrison quoted in Anne McClintock, Imperial Leather (New York and London: Routledge, 1995), p.405, endnote 30.

85. Oikawa, "Driven to Scatter," p.44.

86. BCSC, Removal, p.11.

87. NA, RG 36/27, vol. 1, file 17, "Distribution of Japanese," "Japanese Movement Pacific Coast (Period ending October 31, 1942)," p.4.

88. See Oikawa, "Driven to Scatter," Chapter Two.

89. This figure is derived from the 1941 census, which lists 3.520 females in B.C between the ages of one to fourteen years. There were 2,208 males between the ages of one to nine years. The census also lists 1,356 males between the ages of ten and fourteen, but it must be remembered that some males over the age of thirteen were incarcerated separately from their female relatives. Canada, Dominion Bureau of Statistics, Eighth Census of Canada, 1941, vol.3, (Ottawa: 1946), p.164. 
90. BCSC, Removal, p.11.

91. Adachi, The Enemy That Never Was, p.281.

92. For example, Kay Anderson describes how "In the homes of the [B.C.] provincial elite, young Chinese men, in the absence of sufficient white women, helped with the menial activities of domestic life." Anderson, Vancouver's Chinatown, p.36.

93. Oikawa, "Driven to Scatter," pp.54-58.

94. Ibid., p.48.

95. McClintock, Imperial Leather, p.85.

96. Eric Hobsbawm quoted in McClintock, lbid.

97. McClintock, Imperial Leather, p.161.

98. Oikawa, “Driven to Scatter," p.52.

99. Interview with May, p.57.

100. Ibid., p.52.

101. Ibid., p.50.

102. ㅁid.

103. Ibid., p.58.

104. Ibid., p.54.

105. Ibid., p.55.

106. Ibid.

107. Ibid.

108. Ibid., p.46.

109. Interview with S., p.46.

110. Interview with Hard, p.47.

111. Ibid., p.48.

112. Ibid., p.62.

113. Ibid. 
114. Interview with Kazuko, p.17.

115. Ibid., p.21.

116. Ibid., p.45.

117. Interview with Margaret, p.16.

118. Ibid., p.53.

119. Ibid., p.21.

120. Ibid., p.22.

121. Ibid.

122. Abigail B. Bakan and Daiva Stasiulis, Not One of the Family (Toronto: University of Toronto Press, 1997), p.I1, note omitted.

123. Interview with Aya, p.41.

124. Ibid., p.46.

125. Interview with Louise, p.45.

126. Ibid., pp.12-13.

127. Ibid., p.52.

128. Ibid., p.54.

129. Ibid., p.59.

130. Interview with Ann, p.63.

131. Interview with Esther, p.48.

132. Ibid., p.53.

133. Ibid., p.57.

134. Interview with Evelyn, p.73.

135. See Ruth Roach Pierson's description of the decrease in women's participation in paid employment in 1945 and 1946 in 'They're Still Women After All': The Second World War and Canadian Womanhood (Toronto: McClelland and Stewart, 1986), p.215.

136. Ibid., p.83. 


\title{
Chapter Seven
}

\section{The Known and Unknown: A Community Lost, A Community Remembered}

\begin{abstract}
All along the tracks, wherever they could, crowds of nihonjin lined up to wave good-bye to those going to work camps, to Schreiber and to beet fields, ghost towns and other places. They waved to us and we waved to them, whoever they were. Some we knew, some we didn't, but weren't we all in the same boat - forced to move out of the restricted area? I hated the thought of leaving Eiko behind, so I blew her a gentle kiss.
\end{abstract}

\section{Muriel Kitagawa'}

\section{Introduction}

Chapter Seven, Section One, ends my discussion of the spaces of incarceration where we began, within the space of British Columbia. The relentless pursuit of constructing the mythology of British Columbia as a white "respectable" space entailed the accounting for every last Japanese Canadian within that geographical area and resulted in their banishment and incarceration. I will demonstrate the lengths to which government administrators went in achieving this goal by focusing upon the violence of expelling children and the hospitalized from the restricted area.

Separating families, friends, and kinship networks served to privilege a white bourgeois entitlement to family and social organization. Section Two of this chapter will examine the notion of the family secured through these violent ruptures and underline that white hegemonic masculinity and heteronormativity, as mobilized within a particular family formation, depended upon the demonization, destruction. and rupturing of Japanese Canadian extended family forms and communities. We have seen in past chapters how families and communities were disrupted and destroyed. In this chapter, some of the women interviewed will describe how their families were constituted before and during the Internment and their roles within these families. Their understandings of family as heterogeneous constructions disrupt the normalization of a particular hegemonic family form. 
I will end this chapter by examining the notion of subject produced through Internment narratives and interpretations of these narratives. I will use my notion of "memory of community" to suggest that the "liberal autonomous subject" is one, both informing our understanding of survivors testimonies and our constructions of our own selves as witnesses to these testimonies.

\section{Section One \\ Missing Children, Missing Adults: The Relentless Pursuit of the One hundred-mile Zone}

In a government report dated 31 October 1942, the lengths to which the BCSC went to banish Japanese Canadians from the coastal area were statistically itemized. Every person's whereabouts was accounted for: 579 people were allowed to leave the restricted area prior to March 1942 and were "spread across Canada but under R.C.M.P. supervision;" 19,867 had been moved to various incarceration sites; approximately 225 remained in Hastings Park, slated for impending expulsion; and a "few Japanese families where the husband is a Japanese and the wife is a white woman and vice versa and their children" remained in the restricted area. ${ }^{2}$ The report elaborated upon those remaining in Vancouver who were awaiting removal. They included 105 patients suffering from tuberculosis and the nurses and orderlies taking care of them in the site of Hastings Park. It added that approximately 100 "difficult cases" remained in Vancouver and had been turned over to the RCMP, and twenty-five people were still in the "protected" area of the Kootenays but would be removed in the next ten days. ${ }^{3}$

This section will further discuss the familial and communal separations incurred through incarceration and displacement by examining who remained within the restricted area. In their relentless pursuit of demarcating the boundaries between white spaces of "respectability" and racialized spaces of degeneracy, white citizens had both to banish Japanese Canadians from a space to which it held the power of entitlement and also to create other pathologized spaces. In this extraordinary spatial manipulation, we see how racialized spaces in British Columbia coastal areas, such as Powell Street in Vancouver - "the social and economic centre for Japanese Canadians throughout the province"4 - were blamed as both the proof and the cause of Japanese Canadian's 
disloyalty to nation. In expelling Japanese Canadians from the coastal area, other racially segregated sites were established to further the myth of degeneracy/disloyalty and to legitimate incarceration. In this way, the white-dominated space of the nation could be rearticulated as the reward for the conquering of a community construed as "Other" and disloyal, and the myth of white bourgeois respectability could still be mobilized materially and discursively through the complex spatial zones of contact with Japanese Canadians through the sites of incarceration.

As has been demonstrated in the last chapter, children were profoundly affected by the Internment. The 1941 census indicates that fifty per cent of the females who were removed from the coast were children aged under twenty; thirty-nine per cent of the males removed were children under the age of twenty. ${ }^{5}$ It is important to note that the government reported the census definition of "children" as all who were under twenty years of age. ${ }^{6}$ Children thus also had to be construed as "enemies" in order to justify their separations from their families and their removal from the restricted areas. As we saw in Chapter Three, male children over thirteen were separated from all females in Hastings Park. This age and gendered distinction marked these separated Japanese Canadian male children as necessitating spatial exclusion and also disentitled them from living with their mothers and other female community members. I would suggest that this determination of the age of thirteen was linked to a construction of an Orientalized heterosexuality and masculinity, delimiting spatial contact and heterosexual sexual relations between males and females by imposing upon all males around the age of puberty and older physical separation from females. Hence the construction of the "enemy" entailed an interlocking of a racialized masculinity and racialized heterosexuality.

This racialized masculinity and heterosexuality demarcated by age and by the physicality of separation from both Japanese Canadian women, and white men and women reinforced the notion of Japanese Canadian males as a "threat" to nation. It was not solely male children who were constituted as the enemy necessitating banishment, however, but there is also evidence that female children were forcibly moved to a separate geographical location, far from Japanese Canadian adults.

As was seen in the reports of "missing" family members in the last chapter, it is clear that the government's notion of "family" was not the same as that of those who were 
incarcerated. Keeping children with mothers and/or fathers was not a priority. As we must learn from the separation of Aboriginal children from their parents through the residential school system and forced adoptions, ${ }^{7}$ displacement of racialized children from their families is a technology of colonialism, a definitionary strategy of nation-building, and an attempt to secure white control of communities.

A clear example of the government's exhaustive effort to secure white spaces in British Columbia in 1942 was the forced removal of eighteen children, described as “orphans," living at the Oriental Home in Victoria to Assiniboia, Saskatchewan. The Oriental Home was maintained by the Women's Missionary Society of The United Church of Canada. On 20 March 1942, the United Church reported that "fifteen Japanese girls of various ages" lived at the Home. The eldest was sixteen and the youngest was "just a few years old." In addition, "four Eurasian children. all of whom are Japanese," were listed. Despite the government's description of the children as "orphans." some of the children, in fact, had one living parent. ${ }^{8}$

Although Assistant Under Secretary of State for the Department of External Affairs Hugh Keenleyside argued against this removal, he was still able to construct the "older" girls as potentially "disloyal." In a letter to one of the BCSC Commissioners, he stated: "They are under supervision in an established home and could not possibly be any danger to public security even if the older ones were anxious to assist the enemy." $\mathrm{Mrs}$. Scurrah of Victoria, who was a member of the Advisory Council to the BCSC, did not agree with Keenleyside's recommendation to leave the girls in Victoria and the removal of the children was authorized. ${ }^{10}$

The Board of Home Missions and the Women's Missionary Society of the United Church were opposed to the BCSC's original plan to send the children to "a camp." As Reverend George Dorey, Associate Director of the United Church, stated, "To move nineteen children of various ages, all of whom are girls, and to put them in a camp is to my mind unthinkable on the part of the Government, and I think that unless reasons of extreme urgency dictate another course, we should try to be humane." "Dorey then argued that the children should be sent "in a body" to "a school home" in Assiniboia, operated by the Women's Missionary Society. He also asked Keenleyside if the persons "in charge of these children" from the Missionary Society could accompany them. The 
BCSC accepted the United Church proposal and recommended that twenty children be "selected." Nineteen children were moved from the Home in Victoria on 7 May 1942."2

That the movement of children to Assiniboia was "humane" is arguable. It is the discursive construction of "humanity" that I wish to emphasize here. While I do not argue that removing the children to "a camp" would have also been violent, it is the ways in which other spatial exclusions were achieved and justified that is of interest to me here. Removing the children to Saskatchewan separated them from any Japanese Canadians other than those with whom they moved, including the "living" parents with whom some may have had contact. In 1941, there were 105 people of Japanese origin in the entire province of Saskatchewan. ${ }^{13}$ This movement of children to Assiniboia also extended the monitoring of Japanese Canadians into another provincial jurisdiction, empowering the people inhabiting this area with the responsibility of surveillance and control. The extension and expansion of the spaces of incarceration engaged more and more people in the processes of policing and surveillance. In the case of the institution of the Oriental Home, the movement of the children also reconfirmed the role of the Christian churches in the Internment and in forced movements of children, and materially provided work for their employees.

It is also important to underline that while the government's "official" policy was not to remove "Eurasian" children from the restricted area (see Chapter Five), it appears that the four girls living at the Home were forcibly moved from Victoria to Assiniboia. In this regard, it is also of note that Dorey racially constructed these girls as "Japanese," whereas as was previously mentioned, the government's official policy was that children "allowed" to remain in the coastal area were "Canadians."

What happened to the children who were moved and to their "living parents" is unknown to this author. I have not read any description of the expulsion of this "community" in any historical account. The forced displacement of these nineteen children from Victoria to Assiniboia is discursively described as "humane" by the United Church official. While the Assiniboia space was different from that of the prison camp spaces, all of these incarceration sites, as we have seen, are spatially interconnected and were used to secure the mythologized purity of a white space. How would these children, 
now women, describe their "incarceration" given the complex spatial arrangements of this violence, and the ways in which it has been discursively masked and forgotten?

\section{Not Forgetting the Deceased and Institutionalized}

I remember my mother telling me that one of her memories from Slocan was that of funerals. She described to me the night-time burning of bodies of those who died in the prison camp and how mourners later went to the cremation site to retrieve the bones. Perhaps, as in the case of Esther's mother, some of these remains were transported to other spaces of remembering, becoming a part of what people carried with them. Whether these remains were carried physically or symbolically, the people who died during the Internment are some of the "missing" family and community members whose passing is forever spatially linked to the sites of incarceration.

All of the women I interviewed "lost" people they knew. Most of them witnessed the death of a family member or knew someone who died in their places of expulsion. From the beginning of the expulsion until 31 October 1946, 717 people died, 570 "adults" and 147 "children." 14 While this figure included those who lived outside of the restricted B.C. coastal area before the Internment, the majority of people cited would have been in the various incarceration and forced labour sites. Due to the multiple spacial separations between family members, people were not always able to see their dying relatives or attend their funerals. La Violette, who visited the interior prison camps to undertake his research, reported that "several sons were unable to visit dying parents." 15

One woman I interviewed speculated that her father's health just immediately before Canada declared war with Japan may have been negatively affected from the exclusionary processes in force in Vancouver. Her father had been a translator and worked for the Canadian government after Canada declared war on Germany in 1939. May believed that her father had been hired to censor letters sent from Canada to Japan. He was later fired and May still has the notice of termination from the government in her possession. He received the notice "shortly before he died." May states: "I would also suspect it was quite a blow to him. And having a bad heart, I would not be surprised, knowing what we know about emotional involvement in physical health that that would 
have been something that would have perhaps not hastened so much, but didn't help his health." 16 Her father was in his sixties when he died.

Donna Nagata's work on the cross-generational effects of the incarceration of Japanese Americans investigated the perceived effects of the Internment. She found that Sansei "saw the internment as contributing to health problems and even premature deaths in their parents." 17 Nagata's study included Sansei who had parents who were not incarcerated. As most Japanese Americans living in Hawaii at the time of the Internment were not incarcerated, ${ }^{18}$ Nagata was able to compare Sansei with interned and notinterned parents.

Out of a sample of over 700 people, Nagata found that " $41 \%$ of the Sansei who had a father in camp reported that their father died before the age of 60 compared with only $19 \%$ of those from the group in which a father had not been interned."19 Five percent of the Sansei reported their mother had died. "Fifty-eight percent of the deceased mothers in both groups died before the age of 60 ...mothers who were interned did not differ from non-interned mothers in their age of death." ${ }^{20}$ Nagata concludes, "The findings are suggestive that fathers, in particular, may have been at risk for an early death following the internment." 21

It would be erroneous to conclude from Nagata's findings that the Internment was psychologically more difficult for Nisei men who were incarcerated than Nisei women. Such relativized conclusions are not useful in my opinion. Nagata's work, in this instance, is valuable in raising the question of the Internment's effects on health and pointing toward an examination of its long-term effects. Her work also illuminates how these perceived effects are being raised and interrogated by the children of families who were interned. Nagata's findings also beg the question, "What do we do with the violence we underwent and undergo, and how do we remember the violence?"

As was noted in Chapters Five and Six, people who needed hospitalization during the Internment for physical conditions had to travel to institutions in other incarceration sites or in rare cases, they were sent to Vancouver. These medical emergencies resulted in further separations from family and support systems, as was seen in the case of the woman who was separated from her children when she was sent from the hospital in Hastings Park to the New Denver hospital. The need to maintain the one hundred-mile 
zone forced those requiring follow-up procedures at the Vancouver hospital to make multiple trips despite their illnesses and disabilities. May's sister, who was sent to Vancouver for separate surgeries, had to return to New Denver between surgeries.

I mention the space of the hospital here to emphasize the extent to which whiteness and respectability depend upon materializing the mythology that racialized others inhabit degenerate spaces. The hospital is an epitomic space for signifying pathology, associated as it is with disease and contagion. As we witnessed at the beginning of this chapter, in March 1942, there were 105 people described as "T.B. patients" in the Hastings Park hospital who were to be sent to the "new hospital" at New Denver. ${ }^{22}$ This report indicates that even while they were living in Hastings Park in Vancouver, it was felt necessary to establish a separate hospital within the Park prison site. According to a former staff nurse in the Hastings Park hospital, "The hospital unit was located in the poultry section of the livestock buildings."23 She adds that patients were transferred from the "community," including the facility of the Oriental Hospital in East Vancouver, to the Hastings Park hospital. "Acutely ill patients" were transferred to Vancouver General Hospital but returned to Hastings Park for recuperative care. ${ }^{24}$ Pregnant women imprisoned in the Park went to Vancouver General for delivery and immediate post-partum care. In describing ailing children, she states, "Children suffering communicable diseases were cared for by families and isolated as much as possible in the main residential area under the supervision of a public health nurse...."2s

A new hospital was later built in the New Denver prison camp. Adachi elaborated upon the establishment of hospitals in the incarceration sites when he stated, "Hospitals were either constructed or refurbished in Tashme, Greenwood, Slocan and Sandon, and a 100-bed tuberculosis sanitorium was built in New Denver."26

It may be argued that the provision of medical services was necessary given the needs of the incarcerated. But once again the violence of these processes may be denied unless we examine that it was the securing of a white nation and the hegemony of the white bourgeois subject that spawned the violence of incarceration and displacement, resulting in a network of interconnected social services and government bureaucracies and employment for the white people working within them. The efforts to cordon off people suffering from tuberculosis within the space of Hastings Park and then to build 
other carceral hospital sites are acts of violence adjunct to the confiscation of homes and properties belonging to Japanese Canadians, all serving to materialize spatial domination and control by white bourgeois subjects.

Economic and social domination must be seen as spatially and relationally constituted. While some might argue that the New Denver sanitorium was closer to some of the camps than was Vancouver, I would suggest that the hospitals established in the incarceration sites were not built out of regard for the people incarcerated, but were a further means of control and a way of reinforcing the notion that the camps were pathologized spaces. As we witnessed in Chapter Five, the woman who was moved from Vancouver to the New Denver hospital was separated from both of her children and the foster home found for her younger daughter was not in the New Denver site. Thus hospitalization could entail further punishment and isolation.

An exception to the removal of all hospitalized patients, however, is found in the site of the "Essondale Mental Hospital." In March 1943, there were fifteen Japanese Canadians - eight men, two women, and five children - in this hospital. ${ }^{27}$ In June 1943. there were nineteen (twelve adults and seven children). ${ }^{28}$ In October 1945, there were fifty-eight people (fifty-six adults and two children) in the hospital. ${ }^{29}$ From these statistics, it seems that a unique movement of Japanese Canadians back into the restricted area entailed an incarceration of another kind, when people were psychiatrized and incarcerated in the space of the Essondale hospital. There is also indication of movement from the hospital to other sites, most demonstrably in the case of children.

These few remaining institutionalized people in the Vancouver area may not have been removed to the interior prison camps for financial reasons (how much would it have cost to build another Essondale in one of the camp sites?), yet I would suspect that the existence of the psychiatric institution also served to bolster the sense of "respectability" and "sanity" of the white people living within the space of Vancouver. While removing Japanese Canadians from the coastal area achieved white spatial dominance and created various pathologized spaces of incarceration for those expelled, the psychiatric hospital also served to create a population "different" from those incarcerated in other sites. This "difference" could be legitimated through the "scientificity" 30 of a medicalizing discourse. The mythology of respectability could also be derived from knowing that "others" were 
diagnosed as "pathological" and from the discursive masking of this process: "making the place of confinement look like a hospital." 31 However, more research is needed in examining the site of the Essondale hospital and its role in psychiatrizing and incarcerating before, during, and after the Internment.

From the increase in the number of patients over the years of Internment, the Essondale site was obviously used as another site of banishment. Perhaps it was utilized as a way of disciplining people held in the prison camp sites; many of them would have known of its connotations as a space for the psychiatrized and the threat of it as another possible place of incarceration would hold incredible disciplinary power. It is interesting how statistics according to gender were not given in some of the later reports. But from the earlier reports, it is clear that women were incarcerated in the hospital. While men were sent to the POW camps as a way of promoting the myth of a racialized, degenerate manhood, I would propose that Essondale may have served the purpose of offering another site for the punishment, disciplining, and pathologizing of women. Of course. more work would be needed to determine the practices of the Essondale hospital and how people came to be incarcerated there during the Internment. Some of the patients from the Essondale Hospital were eventually banished from even the small institutionalized area of B.C. to which they had been confined. As my previous research has indicated, there were patients from the Essondale hospital who were deported to Japan, an event that T.B. Pickersgill, Commissioner of "Japanese Placement" for the Department of Labour later described as "merely one of the many trivial details" in the history of the Japanese Division. ${ }^{32}$ Some patients were deported as late as 1946 , after the end of the war with Japan. $^{33}$

I do not have details on the reasons behind the incarcerations in the Essondale hospital, but I can speculate that people were pathologized in many ways, including for reasons of race. In 1973, Michiko Sakata described meeting a man at what she describes as a B.C. "government mental institution." He was probably one of the patients listed in the government's statistics in the reports cited earlier. When Sakata met him, he had been in the hospital for thirty-two years. This is how she re-members him:

He was arrested in 1941 and committed to the hospital for not carrying his registration card identifying him as a person of Japanese origin. On my 
regular visits, I tried to talk to him in Japanese, but he said, "Don't speak Japanese. They are watching us." I tried to talk to him in English, but he could not speak English.... On one of my visits in 1976, I was told that he had stopped eating and had died. ${ }^{34}$

As I have been arguing in this section and the last chapter, the fragmented spatial arrangements of incarceration, forced labour, and displacement defocuses the picture of violence. My emphasis upon the subjects and subjectivities thus displaced is to underline that the experience of violence was an embodied one and part of that violence was a disembodiment, a forceful removal of people from family and community.

I have only begun to re-map these cartographies of violence. What must be remembered is that 22,000 people were re-arranged through multiple spatial reconfigurations. While my work has not been able to undertake an analysis of the Repatriation Survey and the government's policy of forced dispersal and deportation, I would underline that an analysis of this policy and the processes of the reorganization of families and the destruction of communities deserves further attention. ${ }^{35} 4,000$ people were removed from families and deported to Japan. Relationships, families, and communities were ruptured and destroyed through the dispersal and deportations. Community infrastructures were dismantled. In the sites of Canadian displacement, the social organizations for reproducing a sense of self that honoured a historical connection to language, food, Buddhism, and other cultural inheritances had to be rebuilt through new social institutions in the face of hostility and racism. For example, how could one learn or maintain the Japanese language without a language teacher, school, or a community with whom one could speak, in a space where English speakers constituted Japanese speakers as "disloyal"? New Japanese Canadian social institutions would therefore be space-specific. Although my project cannot undertake an analysis of the social institutions initiated in the post-Internment period, I will commence a preliminary discussion of the meanings of "family" produced through Internment narratives. I will conclude this chapter by returning to interrogate the liberal subject informing interpretations of survivor testimonies. 


\section{Section Two}

\section{Discourses of Family}

In this section, I argue that interrogating how we conceptualize and talk about "family" in our histories as racialized people can provide a discursive contestation of a particular hegemonic notion of the "nuclear family," one that normalizes white male domination and the subordination of women and children through heterosexual arrangements. As was previously discussed. a particular notion of family for white bourgeois subjects is secured when racialized "families" can be separated and displaced to multiple sites. Through relations of domination the hegemonic model of family (as a site of male dominance and heteronormativity) also becomes the ideal upheld through exclusions of class, race, gender, and sexuality. While patriarchal relations exist in relations between Japanese Canadian women and men, I wish to contest the tendency to isolate these relations as solely produced within the Japanese Canadian community. I have tried to illustrate ways in which a white hegemonic masculinity produced and was produced through the Internment. Indeed, my work stresses that a racialized masculinity is profoundly connected to the production of white bourgeois masculinity. In my discussion of the family discourse produced through Internment narratives, I am not attempting to idealize the pre-Internment family as one where relations amongst women, men, and children were always equal and caring. What my work seeks to do is to understand how power is productive and illustrate how the constitution of the family was affected discursively and materially through the violence of the Internment.

Women's re-memberings of how their families were constituted and who was "missed" by them during these displacements have led me to conclude that part of what the government attempted to destroy was a complex arrangement of families, kinship networks, friendships, and communities extending themselves into white spaces. It was the rupture of these extended networks, as has been discussed, that are part of the invisibilized effects of the displacements. As we have seen through the last four chapters, the spatial arrangements of the Internment secured these multiple separations and removed Japanese Canadians to spaces where they had to reconstitute themselves, their families, and communities. 
In order to enable the government's separation of family members, it had to constitute the very space of a Japanese Canadian family as degenerate. As we have seen through some of the correspondence protesting the separation of men from their families, there was clear resistance to these acts of separation. The government demeaned the protestations by describing the desire to remain with family members as intrinsic manifestations of being "Japanese." For example, a BCSC report described the people remaining in Steveston in this way: "The remainder of the community wished to be evacuated in large groups. They were almost tribal in their intense desire to remain together and they are now resettled in one of our interior towns, Greenwood...."36 Once again, an Orientalist construction of Japanese Canadians served to portray them as "backward," this time in their desire to remain together in families and communities. The same report states that "it is undeniably a Japanese characteristic that the men-folk will not leave their families unless given reasonable assurance that they will be cared for." 37

As we saw in Chapter Six, the government also ridiculed young women's reluctance to leave their families in taking up domestic service positions in other provinces. A 1944 Department of Labour report outlined what were seen as the "causes" for people's refusals to move east. The report described parents as reluctant to "let their sons and daughters go east away from home before marriage. especially the girls who are brought up to shun independent action." 38 Again the constitution of Japanese Canadian women was in relation to an implied norm for white bourgeois women, founded upon the notion of the liberal subject as "free" and "independent." 39 What was in fact a violent spatial separation of women from families and communities was obfuscated through an essentialist discourse constructing Japanese Canadians as "backward" and "different" from "Canadians." Meyda Yeğenoğlu reminds us that the result of such binary constructions of racialized subjects and Western subjects is "not only the identification of what is Western with what is universal, but also the creation of an essentialist typology in which the distinction between East and West is conceived of as constitutively contrary and profoundly different." Canadians" "difference" to then justify the spatial separations and the violence as a means of inculcating "civilization." The Japanese Canadian family thus became another space to be policed and disciplined through the violence of the Internment. Invoking the notion of 
this family formation as "uncivilized" and "degenerate" reified the white hegemonic family as "civilized" and "respectable." Hence these invented spatialized demarcations were used to discursively justify the violence of the "border policing and reterritorialization"4l of displaced and separated families and communities.

The rest of this section seeks to disrupt the ways in which a hegemonic white bourgeois family formation is reified through Internment narratives. I wish to recognize the deep fissures the separation of family members caused by acknowledging that our families were not fixed entities that could be disrupted and easily reconstituted but rather they included different social arrangements and were forged through complex communal relationships. It is, in fact, in recognizing how the eleven women $I$ interviewed remembered their families and communities that I have felt the necessity to comment on how families and women's roles within them were multiply constituted.

According to the 194 I census, there were 6,150 women over the age of fourteen. Approximately, thirty-four per cent were single (2,078 women). Sixty per cent were married (3,712 women) and six per cent were widowed, divorced, separated. or did not state their status (360 women). Approximately forty per cent of women over the age of fourteen were not married in 1941.42

One of the aspects of my research that led me to examine the familial discourse in the Internment was the fact that three of the women I interviewed - Aya, Margaret, and May - lived in women-headed arrangements before and during the Internment. In addition, the father of another woman died while she was in a B.C. interior prison camp. leaving her mother as sole parent. The 1941 census statistic of "widowed, divorced, or separated" does not include the women whose male partners died or estrangements that occurred between partners during the period of Internment. While it can be argued that many women in the prison camps were "single" parents during the period of incarceration, that is, largely responsible for the parenting of their children due to the removal of men from these sites, ${ }^{43}$ I would emphasize that families were constituted in multiple ways and that some women lived prior to, during, and after the Internment without being financially supported by men. My goal is not to prioritize these social arrangements but to point out that narratives of Internment may reinforce a hegemonic familial discourse, one that in fact does not represent the variety of familial relations or 
the particular roles of women therein. We must, therefore, complicate the notion of the family in our understanding of the Internment and multiple displacements.

Although women growing up in situations similar to that of Aya, May, and Margaret may have been statistically rare - that is whose mothers fell into the category of "widowed, divorced, separated" in 1941 - it is what their "exceptional" status reveals to us that is important to me here. As my project seeks to underline the heterogeneity of Internment testimonies and resist the positivist inclination to generalize from perceived commonalities, it is what these "exceptions" tell us about the "rule" that I find useful in investigating the complexity of subject formation. It is, in fact, the "rule" that is up for contestation here, as applied specifically to my understanding of predominant Internment narratives and constructions of Japanese Canadian subjects, to understand how the "rule" and taken for granted discourses and assumptions may also be about and even perpetuate relations of "ruling."

May, who was 64 at the time of her interview, described her pivotal role in her family when they were removed from Vancouver. She lived in a women-headed family before and during the time they were incarcerated in Slocan. Her mother, who was married in Japan and came from a "fairly wealthy" family, divorced her first husband after immigration because he was a "gambler." May states: "So she ended up going to a minister in Vancouver, which must have been horrendous for her, and he suggested she go to the Oriental Home in Victoria." The information that "The Oriental Home was for women, mostly, and girls," 45 was confirmed by May, although she was also aware that boys also had lived there. May's mother was later sent from the Home to work as a maid in a "wealthy home." Her mother remarried and May was born in Victoria. They moved to Vancouver when May was three.

In October 1941, May's father, her mother's second husband died. May's mother did domestic work for the owner of a major B.C. company after the death of her husband. May was 13 in 1941. Their family - a mother and two daughters, of which May was the elder - had to undergo the many displacements of the Internment.

Even though they lived in Vancouver, May's family was moved to Hastings Park before being sent to an interior prison camp. Her mother was extremely ill when they moved to what she calls, the Manning Pool: "She was extremely sick. She had done some 
housework after my dad died because she needed some money." diagnosed as having Addison's disease. ${ }^{+7}$ May had to begin taking care of the family at this time. She describes her role in this way, "At the age of thirteen, when my dad died I stopped being a kid.... From that point on I simply looked after everything that was happening." 48

Another memory May shared with me was that of her step-brother, her father's nephew adopted upon the death of her uncle. May said she had felt close to this stepbrother as a child. Her step-brother was considerably older, in his thirties during the Internment, and a "playboy" who tried to borrow money from her mother while they were in Slocan. He had no dependents, was living at another site, and made no effort to financially support May's mother or family. At this point, May states that due to their costs for medicine for her mother's condition, food, and other expenses, "I couldn't afford this man in my life. I simply could not afford him."49 She became estranged from him as a result of this process, although her sister maintained contact with him after they moved to Toronto.

It was also May who decided that they would move east when they were forced to make a decision through the Repatriation Survey. May stated: "Later on when we had to decide whether we were staying in Canada or going back, you know the repatriation thing, [my mother] really left it up to me as to whether we wanted to stay or go." 50 May left Slocan first and at the age of seventeen, she moved to Toronto in 1945 to work as a "schoolgirl," "work[ing] for a Jewish home doing housework"s! while attending high school.

May has kept her many letters written to the government after she moved to Toronto. She called to their attention the difficulties in supporting her mother, her sister, and herself on "seventeen dollars a week." 52 She describes what it was like to be responsible for her mother's and sister's welfare: "I think that was part of it, was knowing I had to do it myself. It seemed to me a lot of other kids my age seemed to have an older brother or mother or dad that was doing this. I didn't have that.... It was a tough time." In order to support her mother's and sister's move to Toronto, May gave up her dream to become a teacher and had to quit the Normal School training she had begun. 
May's history complicates our notion of "family" and the roles that women played during the Internment. By witnessing how a young woman took over many decisionmaking responsibilities and financial support for a women-led family, we can acknowledge that women occupied different roles before, during, and after the Internment. Other men may have financially assisted their parents, partners, and children during their incarcerations and separations, but in May's case, the only male in their familial circle did not contribute in this way. These material constraints within the context of incarceration contributed to her estrangement from this sibling.

Margaret's father died when she was two. She was raised by her mother and paternal grandmother. Her paternal grandfather had lived with them but decided to move back to Japan. Her grandmother remained with her daughter-in-law. Margaret described this as her grandparents' "separation" and her grandmother "stayed with our family right to the end." 54 Margaret, therefore, was parented by two women.

In 1941, Margaret was eleven years old. When I asked her if her mother made the decision to go to the sugar beet farm, she replied "to tell you the truth, my grandmother was the strongest person. She was the one who held the family together when my father died.... She was a...really tough lady." 55 Seven members of their family were moved to Manitoba. Margaret, however, had an older brother who assumed a lot of responsibility for the family. Both he and her elder sister worked in Winnipeg to support the family through the winter months. It was through their efforts that the family eventually moved to Winnipeg.

Other women also told me that it was the women in their families who had made the crucial decision necessitated by the Repatriation Survey. Ann, who was in Slocan and whose husband was not with her when the Survey was imposed upon them. reported: "Well, my husband said he decided to go to Japan and I said no. And I didn"t. In the end he didn't." ${ }^{\prime 56}$ When her daughter, Mayumi asked her mother: "How did you work that out, who was staying and who was going?"57 Ann answered: "We couldn't write very much because all the mail at that time was censored." 58 Mayumi pursued her question: "So how did he know you weren't going [to Japan]?"59 Ann laughed when she replied: "Because he knew me." 60 
Esther also remembered that her mother had made the decision to not move to Japan. They were living on a sugar beet farm in Manitoba when they were ordered to sign the Survey. Esther describes: "I recall my older brothers and sister talking about that. And I think they discussed it. But my mother would have nothing to do with it. So I don't think it went beyond just a quick discussion.... So my family just carried on." 61

In describing their experiences of displacement as young women, girl children, and through their depictions of their mothers and grandmothers, women have emphasized that they all played multiple roles in supporting the family economy, some of them giving birth to children, caring for children, working in paid and unpaid labour in the prison camps and in places to which they were dispersed. All of the women I interviewed who were not young children at the time of the Internment made critical decisions that involved massive changes in the social organization of their families and in their geographical locations. What women did to maintain a continuity to other people despite displacement, even agreeing to further displacement in order to support the survival of people they cared about, is unimaginable. These thinking, caring, active women, now so much a part of my own memory, challenge us to remember the sites of incarceration as places where people struggled to survive and where community can be a space where the struggles of others are remembered.

\section{Contesting the Violences that Destroy Communities, Families, and Cherished Relationships}

What is difficult in the fragmentation of the Internment and more generally in analyzing how systems of domination interlock is to actually see what these divisions produce. The government's mobilizations of discursive hierarchies of gender, race, and class created real material differences in the sites of incarceration at the same time as the violence and oppression of each site is masked by the very multiplicitous and relational nature of oppression. It is difficult, due to the geographical and material fragmentation of the Internment sites and their discursive differences, to see and name the entire picture of violence.

As I have previously emphasized, families were multiply constituted and extended beyond relations of a closed "parent-child" system and of "blood." When government 
administrators laid out the spatialization of the Internment, they argued that working on the beet farms and living in "self-support" communities was a way of keeping "families" together. What was unique about the sugar beet and "self-support" incarcerations was that most men of all ages were allowed to remain with their immediate families in these sites. $^{62}$ Farmers in fact demanded that able-bodied men be sent to work on their sugar beet farms.

In describing these incarceration sites as a means of "keeping families together," white men could claim "respectability" by discursively invoking the notion of family as something to which they were clearly entitled while professing to allow the "choice" of remaining with their families to Japanese Canadians. This discourse of family also reinforced the notion that when a man who is constituted as the head of a family is present, then the family is complete. Thus what is discursively produced is the normalization of the hegemony of heterosexual relations and male (head of the house) domination.

Yet, as we have seen, "families" in these spaces were not the same as those previously constituted in B.C.; the "missing" cannot simply be forgotten by survivors through the obfuscating term of "family" promoted in its stead. What the terminology of the "family" used by the government produces is another forgetting of the violence: in this case, what is the notion of "family" without community? One of the innumerable effects of the Internment is the destruction of constellations of people, and the imposition of a kind of singularity and autonomy through processes of removing family from community, partners from partners, lovers from lovers, children from family, mothers from sons.... What gets promoted again through this notion of autonomy is the hegemony of the liberal subject, independent from community, unimplicated in the struggles of others.

I have argued that the government's demeaning of Japanese Canadian family formations was used to ideologically justify the Internment and displacements. It served to discursively produce the forgetting of the violence simultaneous to the enactments of violence. The Orientalist construction of the essentialized Asian family as one where people are tied to each other and their Asian origins through a conforming loyalty has historically been used to further the notion of Asians as other, unable to conform to the 
demands of a liberal democracy, undeserving of the rights of the liberal subject. ${ }^{63}$ It is part of the Orientalist discourse mobilized to imagine and construct Asians as outside of the nation. This imagining was materialized through the expulsion, incarceration and displacements and the discourses produced in their justification. My chipping away at the discourse of the family reiterated by the government during the Internment is an attempt to understand why this discourse was used and how its Orientalist recitings reify the white liberal subject and exclusionary entitlements to nation. It is also to underline how violence is produced and legitimated through the construction of hegemonic subjects.

It is in light of this violence done to our community that I urge us to be cautious in how we construct "family" in our imaginings and representations. I would hope that we can envisage a multiplicity of family forms, inclusive of all the people we cherish and cherished, as an echo of the possibilities of a community that does not aspire to a singularity and autonomy but seeks to remember each other.

Through a discussion of some of the spaces of Internment and dispersal, I have attempted to show how these spaces are relationally constituted and multiply overlapping. Forcibly moving people across spaces produces a nation different than that which is believed to be spatially fixed and unchanging. To acknowledge how space is used to confirm and justify domination is to see how different spaces constitute or deny the rights of citizenship. To understand how women negotiated these spatial separations and how they describe them is to inevitably see how displacement produces gaping holes, the "spaces of missing" in families and in communities. The tactic of spatially separating people was the sine qua non of the Internment and I have attempted to illustrate how displacement was used to destroy communities, families, and people's very selves. People, however, resisted, contested, negotiated the violence of the Internment in various ways and I now turn my attention to one means of expressing resistance that I feel has been overlooked, missed in the rush towards containment in the representation of women survivors. 


\section{Resisting the Hegemony of the Liberal Subject}

I have indicated throughout chapters three to seven that women construct their memories and themselves in relation to other people, both family members and community members. This re-membering of the violence of the Internment and displacement, constructed relationally is what I have referred to as "memory of community." 64 Throughout this thesis, I have argued that survivors' memories have been mobilized through various representational forms to construct the subject of Internment as "knowable." Discursive constructions of Japanese Canadians as "silent," "passive," exhibiting a "shikata ga nai attitude," are processes through which the subjects of Internment are subjugated and I consider these processes to be mechanisms of procuring the forgetting of the violence experienced by them. I will illustrate concretely how interpretations of women's testimonies can serve as a technology of containment and reductively occlude their complex negotiations in remembering the violence.

In an essay based on interviews with Issei and Nisei American women, Malve Von Hassel analyzes the dynamics of Issei women's self-presentation and the ways in which their testimonies are interpreted by their daughters. What is revealing in Von Hassel's interpretation of Issei women's testimonies is how she reduces particular phrasings to a demonstration of their "submission and acceptance." This conclusion is reached, for example, after her reading of a woman's statement, describing the loss of their family dry-cleaning business. The woman interviewed states: "There was a chance to claim losses but though we submitted our claim in writing, nothing ever came of it. But that's all right - it wasn't only us. Everyone got taken, not just us. No one is upset about it. It was okay, because that was the war."

What strikes me in these comments are the phrases "it wasn't only us. Everyone got taken, not just us." This recognition of others, in my opinion, is a referent to family and community, that is, the Japanese American community disrupted and dispersed through the processes of forced removal and imprisonment. There is an implicit understanding that many people suffered as a result of the forced removal and there is also an examination of the testifier's position in relation to others. The understanding that people who survived the incarceration and dispossession carry this memory of community 
and position themselves within a community of memory is critical to our developing a deeper analysis of the processes of witnessing and interpreting oral testimonies.

While Von Hassel argues for a more complex reading of Issei women's selfexpression, her work conceptually links the themes of silence, femininity, and submission to Japanese cultural origins. Beyond the critique of the reiteration of the racialized and gendered representations of Japanese American women that Von Hassel's paper promotes, I would argue there is more generally in most of the Internment literature a presumption that the subject of the Internment is a liberal humanist one and s/he is judged according to the weight of this presumption. If we read women's testimonies according to the standard of autonomous, rational, subject, we will be disinclined to see the complexity of negotiation in their words and hover towards reading their insistence on relationality and situating themselves within an interactional field of loss as non-autonomous and therefore suspect.

I will not review all of the instances where the women I interviewed situated themselves within a community remembered while remembering their own experiences of incarceration and displacement. I will point out a couple of examples that have certain resonances with the testimony used by Von Hassel to conclude that the women demonstrated "submission and acceptance."

When Kazuko described how her family was told by the RCMP that they had to move from their home, she stated:

We opened the notice and it said, "You have to leave this place in twentyfour hours. Just one baggage per person." So we didn't have much time at all. Because this wasn't expected. The main thing for which we were lucky - because actually the men had to separate from the family - we were lucky because we were all together most of the time, the evacuation time. ${ }^{66}$

Another example is when Margaret was describing how her grandmother lost her "family things" when they were forced to leave Richmond:

My grandmother had a lot of heirloom things, so when the government said, "You have to move, you have to leave everything, it'll only be a matter of year and a half, two years tops. Leave everything and you're only allowed one baggage." So we had this woodshed which locked, so my grandmother put everything in there, locked it up, hoping you know, within a couple of years to come back and claim it all. But when my 
brother went back after the war, they had smashed in the windows, taken, smashed everything that they could smash and took whatever was valuable. So, we had nothing left. I think that was the hardest part for my grandmother. Cause it was all family things that she had left. That was very hard for her. Well, that's war. Yeah. I think a lot of people went through that, anyways, you know. It's not just us. ${ }^{67}$

Lastly, here is an example from Aya's testimony:

But I think it's not only me. It's all the other people too. There's so many who experienced different hardships. Even in the sugar beet farms, if they had a family, small kids you know, and they're not used to the cold climate. I'm sure they had a, you know, a hard time too. So I guess, wherever you were shipped out to, you know, I'm sure they all went through different hardships. ${ }^{68}$

Kim Lacy Rogers has concluded that two narrative forms arose in her interviews with African American men and women who had been active in the civil rights movement. She describes these two forms as the trauma narrative and the narrative of redemption. Using Judith Herman's work on posttraumatic stress syndrome, Rogers describes traumatic narratives as those "encoded in the form of vivid sensations and images." She adds that these narratives give "an otherworldly quality to appalling scenes of violence and terror." ${ }^{\prime 69}$ Rogers states that redemption narratives frequently follow the trauma narratives; the former emphasize "physical rescue or preservation from evil, or on the redemptive aspects of relationships that save the narrator from fear, isolation, or emotional collapse in the face of violence or death." 70 I would prefer to see testimonies of historical trauma as more complex negotiations of violence than the dichotomization proposed by Rogers. I would propose that the expression of trauma is not as discretely separate from the different narrative voices expressed through testimony. What is discretely determined by Von Hassel in the example above as "submission and acceptance" is a narrative so steeped with the trauma of loss and in fact articulates, within the moment of testifying, a reconstitution of others' losses as well. In this way, survivors are in fact recognizing and implicitly naming their losses within an understanding of a community's loss.

It is crucial to recognize that the phrasings of testimonies are part of a larger negotiation of the painful memory of that violence. What is interesting to me in the "interpretation" of testimonies of Internment survivors is how such interrelational and 
complex constructions of traumatic histories are simplistically reduced and essentialized as those reflective of "passivity and acceptance" or "translated" as evidence of "shikata ga nai." I would like to forward the argument that such reductive interpretations and representations of testimonies are riddled with Orientalist assumptions of Japanese Canadian/American subjectivity and are also reflective of a Western modernist subject seeking and claiming to "know" the "Other". This modernist subject position is informing not only the white bourgeois subject but also those who aspire towards this subject position through our performances of how we are different than the "Other". We also presume our own autonomy in our attempts to dissociate our dependence upon the construction of "Others" as critical to the production of our very selves. Our own complicity in these relations of domination can therefore be concealed and denied.

Donna Nagata has also commented on descriptions of the Internment where Japanese Americans compare themselves to other people who were incarcerated. She calls this "phenomenon," "the denial of personal disadvantage" and elaborates this concept in this way:

Individuals who have been disadvantaged or victimized often rely on social comparisons with others to assess their status...(i.e., downward comparisons), can help victims believe that their situation could have been worse, reduce other-blame for the circumstances, and maintain a sense of justice. Research suggests that stigmatized individuals are especially likely to compare themselves with others who share a common fate within their own group. Such in-group comparisons can play a vital role in protecting the self-esteem of the stigmatized individual. ${ }^{71}$

Nagata's use of psychological discourses to explain why the testifier may compare the self to others in a testimony emphasizes the "individual" and his/her behaviour. While I do not reject the analysis that esteeming the self is critical in surviving violence, what concerns me in her psychological discourse is the way in which the survivor is isolated in the epistemological construction of the "individual."The survivor is thus viewed as the "autonomous" narrator and her/his attempts to "esteem" others who are "victimized" are reduced to her/his own need to protect "self-esteem" and the self.

Meyda Yeğenoğlu states, "Understanding power as a productive and formative process requires a questioning of the presumptions of the paradigms which conceive of the subject in terms of the primacy of mind...."72 I use this statement not to criticize 
psychology per se, but to rather point to the necessity of interrogating inherited discourses that we as representers of the Internment utilize unquestioningly. I underline our own power as cultural producers and how that power is a "productive and formative process."

My work argues that a larger understanding of the violence of the Internment is needed, but not one that further isolates the survivor from community. I seek to understand, through the examination of the violence of the Internment, how the subject reconstructs herself and remembers the violence relationally. This rendering of the violence is a profoundly embodied one and my attempts to materialize the spaces of that violence are one way of emphasizing its embodied nature. Memory and the mind reconstitute the violence in multiple ways, but we must recognize that what also gets reconstituted through memory and is therefore integrally linked to the psychological are the subject's own embodiment and the embodiment of those with whom one underwent the violence and who experienced it differently.

Rather than focus on how the survivors' testimonies reflect a subject position not in keeping with what is presumed to be the norm, in other words the liberal, autonomous subject, I would like to attend to how their testimonies narrate their selves interrelationally and hence in contestation of the norm. I believe that interrogating the ways in which the autonomous subject (and our complicities with that subject constitution) inform our interpretations of these testimonies is critical to understanding how domination and violence may be contested. This is particularly in keeping with an understanding that part of the violence of the Internment were the mechanisms it mobilized in separating the self from cherished others, forcing people to reconstitute themselves without communal supports. Interrogating our own subject positions in relation to that of the survivors may also begin to unpack the ways in which discourses constructing Japanese Canadians as lesser than (by way of their imputed lack of: "voice," "resistance,"... or by their excess of: "reserve," "silence,"...) “Canadians" are echoes of an othering discourse servicing a notion of the universal Western bourgeois subject.

Despite their multiple separations from each other and the annihilation of some of their relationships, survivers keep these relationships alive within a mnemonic record. I read these articulations of the interrelatedness of life and loss as resistance to domination and a hegemonic subject that by its very definition must forget his/her attachments to 
others. Embodying the self within this memory of community marks the grief for the absence of all of the absent others and continues to produce their embodiment thus underscoring the connection of the testifying self to others. I would also argue that these statements evoking a "memory of community" reveal in innumerable ways the magnitude of the violence; even within the description of how the violence affected one's self, there is a recognition of the wider context of violence against an entire community. Lawrence Langer's description of survivors of the Holocaust as being "pursued not only by their own earlier traumatic moments but by the traumas of others too,"73 has a certain resonance here with the relational reconstruction of the Internment. While some may read complex negotiations of self in relation to others' experiences of violence as "submission" and "acceptance," I read them as resistance to the very subject positions that enable domination. Accordingly, the ability of survivors of the Internment to recognize their own subject position relationally and identify others' losses in relation to their own are contestatory of the autonomous subject who must necessarily see the self as divorced and therefore unimplicated in the subordination of others.

\section{Conclusion}

In this chapter I have continued to demonstrate the ways in which violence was enacted through the multiple separations and displacements of the Internment. In their relentless pursuit of securing the one hundred-mile coastal zone as a space of white supremacy and control, white bourgeois subjects accounted for every person of Japanese origin, going to great lengths to forcibly move children and the hospitalized to other locations. An exception to this removal from the coastal area was the seeming exemption of people hospitalized in the site of the Essondale Hospital. This site, however, represented another kind of incarceration and, as we have seen, may have actually continued to serve as site of imprisonment and exile decades after Japanese Canadians were allowed to return to the coast in 1949. As people were forcibly dispersed from the sites of incarceration, other people missing from families were the deceased and those who were deported to Japan. The multiple displacements and the destruction of communities necessitated the reconstitution of selves, families, and communities in different spatial arrangements. In order to further occlude the violence of these familial 
separations, discourses were mobilized that demeaned the space of family itself, equating the need to be with family and community with a "backwardness," proof of an essentialized and racialized "Japaneseness." As people left the physical sites of incarceration through forced dispersals, the reconstituted family became a space for managing and negotiating the memories of the violence.

Reductive interpretations of survivor testimonies may continue to obfuscate the violence of the Internment and contribute to a containment and forgetting of that violence. Through Chapters Four to Seven, women have offered us ways to remember the violence and all of those who were subjected by it; they have also offered the possibilities of contesting the autonomous subject whose autonomy is attained through violence. In Chapter Eight, I will examine how the knowledge of the Internment is passed down to daughters of families who were incarcerated and Chapter Nine will illustrate how this knowledge is implemented through understandings of self in relation to violence and the nation spaces in which these women continue to live.

\section{Endnotes: Chapter Seven}

1. Kitagawa quoted in Roy Miki, "Introduction: The Life and Times of Muriel Kitagawa," in This Is My Own, p.1, note omitted.

2. NA, RG 36/27, vol. 1, file 17, "Japanese Movement - Pacific Coast (Period ending October 31,1942$), "$ p.l.

3. Ibid.

4. Audrey Kobayashi, Memories of Our Past, p.8.

5. Canada, Department of Labour, Administration, p.2.

6. Ibid. In the same report utilizing 1941 census figures, people from the ages of twenty to thirty-four were designated "youths." All of the women I have interviewed would have been included in the government categories of "children" or "youths" in the 1941 census.

7. For an analysis of the effects of forced removal of Aboriginal children from their families, see for example, Elizabeth Cook-Lynn, Why I Can't Read Wallace Stegner and Other Essays (Madison: University of Wisconsin Press, 1996); Janet Campbell Hale, Bloodlines (New York: Random House, 1993); Patricia Monture-Angus, Thunder in My Soul (Halifax: Fernwood, 1995), pp. 59, 88. For a description of the residential school system, see, J.R. Miller, Shingwauk's Vision. 
8. NA, RG 25, G2, Volume 2779, file 773-G-40, letter from Reverend George Dorey to Dr. H.L. Keenleyside, 20 March 1942.

9. NA, RG 25, G2, vol.2799, file 773-G-40, "Movement to a school home in Assiniboia of Japanese Girls in Oriental home in Victoria - Proposals of United Church of Canada Board of Home Missions," Keenleyside to Mead, 21 March 1942.

10. NA, RG 25, G2, vol.2799, file 773-G-40, “Movement to a school home in Assiniboia of Japanese Girls in Oriental home in Victoria - Proposals of United Church of Canada Board of Home Missions," Mead to Keenleyside, 27 March 1942.

11. Ibid., emphasis added.

12. Although the file states that twenty girls were to be "selected," a later BCSC report indicated that nineteen "orphan children" were removed. NA, RG 25, vol.2939, file 2997 40, part 1, "Japanese Population, Location by Province as at March 27, 1943," p.3. This appears to match the total of residents noted by Dorey. Note that an earlier memorandum reported, " 18 homeless children have been evacuated to a Mission School in Assiniboia, Saskutchewan." See NA, RG/27, vol.2, file 17, "Distribution of Japanese."

"Memorandum Covering Japanese Movement Pacific Coast, 9 June 1942," p.3.

13. Adachi, The Enemy That Never Was, Appendix One, "Immigration and Population." p.413.

14. NA, RG 25, vol.2939, file 2779-40 (part 2), "Japanese Population in the Dominion of Canada as of October 31, 1946," p.3.

15. La Violette, The Canadian Japanese, p.151.

16. Interview with May, pp.4-5.

17. Donna Nagata, Legacy of Injustice, p. 141.

18. Gary Okihiro states that " 1,400 , or less than 1 percent, of the territory's Japanese were interned." Okihiro, Cane Fires: The Anti-Japanese Movement in Hawaii, 1865-1945

(Philadelphia: Temple University Press, 1991), ix. Okihiro traces the development of the anti-Asian movement in Hawaii, countering the notion of Hawaii as an "example of racial harmony." He argues that plantation owners allied with the territorial government and the U.S. military in their desire to control the Japanese American population in Hawaii.

Ronald Takaki also complicates our understanding of the position of Japanese Americans inhabiting different geographical locations, by describing how "During the morning of the attack, two thousand Nisei serving in the U.S. Army stationed in Hawaii fought to defend Pearl Harbor against enemy planes." Takaki, Strangers from a Different Shore (New

York: Penguin, 1989), p.384. See also pp.385-386.

19. Nagata, Legacy of Injustice, p.141.

20. Ibid. 
21. Ibid.

22. NA, RG 36/27, vol. 1, file 17, "Distribution of Japanese," "Japanese Movement Pacific Coast (Period ending October 31, 1942), p.1.

23. Irene I. Smith, "Hastings Park Hospital - Memories of Nurse Irene (nee Anderson) Smith, The Bulletin, 38, 4 (April 1996): 24.

24. Ibid.

25. Ibid., my emphasis. Irene Smith also describes how "Japanese RNs" were "paid on the scale set for internees rather than RN salary." The "Japanese" doctors, she states, "visited and ordered medication for their patients but prescriptions and treatments had to be approved by salaried medical staff." Smith describes her work as a "challenging and interesting experience."

26. Adachi, The Enemy That Never Was, p.263.

27. NA, RG 25, vol.2939, file 2997-40, part I, "Japanese Population, Location by Province as at March 27, 1943," p.2.

28. NA, RG 25, vol.2939, file 2997-40, part 1, "Japanese Population in the Dominion of Canada as of June 30th, 1943," p.2. Note that the gendered breakdown between men and women was not included in this and subsequent reports.

29. NA, RG 25, vol. 2939, file 2779-40, part 2, "Japanese Population in the Dominion of Canada as of August 31st, 1945," p.2.

30. Michel Foucault, "Confinement, Psychiatry, Prison: A dialogue with Michel Foucault, David Cooper, Jean-Pierte Faye, Marie-Odile Faye, and Marine Zecca," Politics, Philosophy, Culture: Interviews and Other Writings, 1977-1984, edited with an introduction by Lawrence C. Kritzman (New York and London: Routledge, 1990), p.180.

31. Ibid.

32. Oikawa, "Driven to Scatter," p.68.

33. See Gabrielle Nishiguchi's "'Reducing the Numbers': The 'Transportation' of the Canadian Japanese [1941-1947], (master's thesis, Carleton University, 1993), p.3, where she states that five sailings deporting people to Japan occurred between 31 May and 24 December 1946. Nishiguchi adds, "Among the passengers were World War I veterans, stretcher cases, psychiatric patients, seniors, and families - including pregnant women, dependent children and babies. Over sixty-five percent of them were Canadian citizens by naturalization or birth."

34. Japanese Canadian Centennial Project, A Dream of Riches, (Vancouver and Toronto: The Japanese Canadian Centennial Project, 1978), p.3. 
35. See Sunahara's description of the Repatriation Survey and the policies of dispersal and deportation in The Politics of Racism. See also Nishiguchi's analysis in "Reducing the Numbers."

36. BCSC, Removal, p.5, emphasis added.

37. Ibid., p.13, emphasis added.

38. Department of Labour, Administration, p.42.

39. Whether white bourgeois women attained this "norm" is another question. It is the mobilization of discourses of "independence" that is of interest to me here and how it services the notion of racialized others as being "dependent" and "other."

40. Yeğenoğlu, Colonial Fantasies, p.104.

41. Ibid., p.136.

42. Canada, Dominion Bureau of Statistics. Eighth Census of Canada, 1941. Vol. 4.

(Ottawa: 1946), p.21. Note that my calculations differ from those of the Department of Labour who reported that fifty-eight per cent were single, thirty-eight were married, and four per cent were widowed, divorced or separated. In Department of Labour, Administration, p.3.

43. More work should also be done in examining how women parented within the sites of incarceration. As was suggested by one of the women I interviewed, women shared these responsibilities and she felt cared for by many adults and elder children.

44. Interview with May, p.64.

45. Ibid., p.65.

46. Ibid., p.25.

47. According to the Webster's New World Dictionary, Addison's Disease is "caused by failure of the adrenal glands: it is characterized by anemia, weakness, low blood pressure. and brownish discoloration of the skin" p.15, emphasis added.

48. Interview with May, pp.27-28.

49. Ibid., p.28.

50. $\underline{\text { Ibid. }}$.

51. Ibid., p.42.

52. Ibid., p.59.

53. Ibid. 
54. Interview with Margaret, p.25.

55. Ibid., pp.29-30.

56. Interview with Ann, p.47.

57. Mayumi quoted in interview with Ann, p.49.

58. Interview with Ann, p.50.

59. Mayumi quoted in interview with Ann, p.50.

60. Interview with Ann, p.50.

61. Interview with Esther, pp.66-67.

62. There was the exception mentioned in Chapter Five of the woman who lived in a "self-support" site and whose husband was incarcerated in a POW camp. There are undoubtedly other cases where men were removed from these sites.

63. For an analysis of how the essentializing discourse of Asian families is mobilized through films, see Kirsten Emiko McAllister, "Asians in Hollywood," Cineaction 30 (Winter 1992): 11.

64. Tomoko Makabe and Ronald Takaki both use the term "community of memory." Makabe attributes the term to Robert N. Bellah and defines it as "a community that people do not choose but are born into, where people inherit a commitment to historical ties through the community and commonly shared experiences." Makabe. The Canadian Sansei, p.91. Takaki does not define his use of this term but uses it to describe members of a community who are "recovering roots deep within [the United States] and the homelands of their ancestors." Takaki, Strangers, p.488. My use of the term "memory of community" is to emphasize how a person re-members the self in relationship to other people. I also suggest that memory and community are not fixed but shift in relation to subject position, spatial situatedness, and other subjects.

65. Malve Von Hassel, "Issei Women: Silences and Fields of Power," Feminist Studies 19, 3 (Fall 1993): 252.

66. Interview with Haru, p.12, emphasis added.

67. Interview with Margaret, pp.28-29, emphasis added.

68. Interview with Aya, pp.67-68.

69. Kim Lacy Rogers, "Trauma Redeemed: The Narrative Construction of Social Violence," in Interactive Oral History Interviewing edited by Eva M. McMahan and Kim Lacy Rogers (Hillsdale, NJ: Lawrence Erlbaum Associates, 1994), p.33. 
70. Ibid.

71. Nagata, Legacy of Injustice, p.155.

72. Yeğenoğlu, Colonial Fantasies, p.113.

73. Langer, Holocaust Testimonies, p.13. 


\section{Chapter Eight \\ "IT IS PART OF MY INHERITANCE"' \\ HANDING DOWN MEMORY OF THE INTERNMENT}

Time heals the details, but time cannot heal the injustice. My children will not remember the first violence of feeling, the intense bitterness I felt, but they will know that a house was lost through injustice.

\section{Muriel Kitagawa ${ }^{2}$}

It is part of my inheritance, as its effects are my children's inheritance and their's. And it will just go on.

$$
\text { Mayumi }^{3}
$$

\section{Introduction}

Throughout this thesis, I have been drawing attention to the limits placed upon understanding the violence of the Internment, if we only construct it as part of the linear past. History reduced to temporality occludes the contrapuntal construction of oppression. I have argued that a theory of spatialization enhances our ability to understand how systems of domination are interlocking in their complex spatial and temporal iterations.

In this chapter, I will continue to argue for a spatialization of our understanding of social domination, specifically in relation to the long-term effects of the Internment across the geographical separations of the dispersal and across generations. This line of argumentation will be pursued through an examination of the testimonies garnered from eleven women, their daughters, and one granddaughter.

I will begin Section One of this chapter by presenting the notion of crossgenerational "transmission" of historical trauma, generated in the psychological literature on children of survivors of the Holocaust. I will then examine how this concept of transmission is utilized by Donna K. Nagata in her study on Japanese American Sansei. This literature review will be used as a backdrop to my analysis of the ways in which children of families who were incarcerated learn about the Internment. In Section Two, I will propose that space is integrally linked with how knowledge of violence gets constructed. I will investigate how women "hand-down," acquire, and negotiate their memories of the Internment in the family space and Japanese Canadian community spaces. 


\section{Section One}

Yael Danieli defines "intergenerational transmission" in relation to the Holocaust

as:

...behaviors of survivors' offspring (children born after the war) which are dynamically assumed to have their origins either in symbolic relationship to their parents' Holocaust experiences or to be shaped by Holocaustrelated pathogenic behaviours."

It is clear from Danieli's definition that part of the psychological intellectual inquiry into "intergenerational transmission" concentrates on pathogenesis. In similitude with the literature on the Internment, the notion of "silence" is also mapped onto the survivors of the Holocaust to describe the "gaps" in knowledge experienced by survivors' children." As I have earlier stated, the notion of the "silence" of survivors of violence as the cause of difficulties experienced by their children is reductive and occludes the social construction of violence and its forgetting. Attributing to the one source - survivor silence or speech - the disorientations experienced in a capitalist culture where racialized and gendered children undergo multiple exclusions is simplistic and pathologizing, to say the least. This double-bind of the deleterious effects of an excess of "silence" or "speech" imposed on the survivor of the Holocaust is exemplified by Bergmann's statement. "There is...the difficulty of determining which has a more salutary effect and which a more traumatic one: the endless account of tribulations or the silence practised by many about the traumatic past." This statement begs the questions: "How much speech is too much?"; "How little is too little?"; and "How does a survivor negotiate memories of violence within a culture where the management of these memories is relegated to her/him alone?"

Danieli, however, extends the notion of what she calls the "conspiracy of silence" beyond the parent-child dyad and situates it as existing "between survivors, their children. and society," a result of "pervasive negative societal reactions and attitudes, such as indifference, avoidance, repression, and denial of their Holocaust experiences, that most survivors encountered after the war."7 She also raises the question of the position of expert mediators in defining pathology by interrogating the psychological comportment of psychologists and researchers in relation to Holocaust survivors. Namely, she mentions the "pervasiveness of bystander guilt" as accounting for the "overuse, stereotypical 
attribution, and reductionist misinterpretation of concepts such as 'survivor guilt'..." and their application to behaviours exhibited by survivors. ${ }^{8}$ While I would complicate the notion of "bystander guilt" by problematizing the witness' position of power in relation to the survivor, Danieli's emphasis on the social response to survivors opens up avenues of interrogation that go beyond the closed space of parent-child relations.

Donna Nagata uses the research on children of Holocaust survivors in her groundbreaking survey of over 700 non-interned Sansei in the United States, which included over forty in-depth interviews. Nagata uses the psychological research demonstrating that "The legacy of the Holocaust continues to have an impact on survivors and their children" to illustrate how "the Internment continues to effect...Japanese Americans and their children." She cautions, however, that an overemphasis on the psychiatric literature may lead to "blaming the victim" by "labelling survivors and their children as permanently impaired socially and emotionally."10 Nagata adds that her research investigates the "existence of positive cross-generational impacts [of the Internment] on the Sansei generation."

Nagata's major contribution to the literature on the Internment of Japanese Americans by the United States government is her conclusion that "the repercussions of the incarceration extended far beyond the date [of the closing of the internment camps]. Individuals, families, and whole communities felt the economic, social, and psychological ramifications for years to come." " From her sample of over 700 Sansei, Nagata underlines that "the vast majority of Sansei feel that the incarceration has affected their lives in significant ways."12

Nagata's work, however, maintains the closed space of parent-child relations as the site of scrutiny. As occurs in some of the psychological literature on survivors of the Holocaust, Nagata uses the trope of "silence" to describe the difficulties in speaking about the Internment. She does, however, assign responsibility for this "silence" to the survivors and their children in her statement, "Rather than seeking explanations for the silences solely within the Nisei or Sansei generation, the findings suggest that the interactional pattern between the generations best accounts for the lack of communication." I3 Importantly, Nagata also emphasizes that the "social context has contributed to the Siansei's lack of information."14 
While Nagata concludes that "silence" is a "major long-term effect of the internment," 15 her work in fact complicates our notion of what constitutes "silence" in relation to the transmission of knowledge of the Internment. In quantitative detail, most of which I am unable to repeat here, she lists information on how Sansei learned of the Internment, how many of them learned of it from their interned parent(s), at what age. etc. She also notes differences in how Sansei with no parents interned, one interned parent, and two parents interned reported intergenerational communications of the incarceration, and how Sansei in different areas of the United States, including Hawaii, reported this communication. Contrary to the popularized notion of survivors as being "silent" about the Internment, "close to half of both the Two-Parent [interned] and One-Parent [interned] Sansei" in Nagata's study reported "first learning of the internment by talking with their parents." 16 In addition, "Half... of the interviewees who had a parent interned reported their age of first memory [of learning about the Internment] to be before junior high school."17 Nagata admits that her respondents, by the very fact they were willing to disclose their opinions to a researcher, may have favoured those who had discussed the Internment with their parents. Yet her study's contribution is in providing detailed information generated by children of incarcerated families on how specific knowledges of the Internment are conveyed to this generation. Her examination of the geographical situatedness of the Sansei respondents also makes the connection between space and its relationship to knowledge production.

My work differs from Nagata's in that I would like to complicate our understanding of how memories of the Internment are "handed down" to children and how different spaces construct memory and forgetting of this violence differently. I would also emphasize, as I did earlier in relation to discourses presenting the Internment as leading to improved social conditions for those who were incarcerated, that attributing "positive impacts" to the Internment is indeed problematic. Foucault offers us a way of understanding the exertion of power through the Internment as producing various resistances. I would hence prefer to situate the "positive" ways women cope with their understandings of the Internment as varied forms of resistance to violence and not as positive "effects" of the violence. 
The only Canadian published study on the Sansei generation is that conducted by Tomoko Makabe. While Makabe's important contribution of Japanese and English language publications of oral histories generated by Issei women must be recognized, ${ }^{18}$ some of the conclusions reached through her study on the Sansei are troubling and require some examination here.

Using "intensive qualitative interviews" with sixty-four Sansei, Makabe seeks to discover "the forms by which, and degree to which, they identify with their ethnicity as Canadians of Japanese descent."19 Although she admits to using a rather limited sample of respondents ranging in age from 25 to 52 years, Makabe's interpretations of their testimonies may be misconstrued as generalizations applicable to everyone of the Sansei generation, especially given the title, The Canadian Sansei. Her emphasis upon each generation as a monolithic category is witnessed in concrete generalizations such as her reference to Sansei as "100\% Canadians." ${ }^{20}$ Her construction of Japanese Canadians as a group about whom knowledge can be exhaustively produced and acquired is also apparent from her conclusion that, after this study, her "understanding of the JapaneseCanadian community...seems almost complete."21 The sociological notion of "ethnicity" used in her study is not interrogated and is in fact adapted from the definition used by the government statistical agency, Census Canada. While I cannot undertake an extensive critique of Makabe's work, I point out these two broad methodological issues positivist generalizations to construct a unified category of racialized subjects and a unified notion of "Canadian" and non-interrogation of notions that are highly contested in critical studies on "race" - as underpinning the findings of her study.

Interestingly, Makabe does cite Nagata's work in her study, in reference to reiterating the construction of the Nisei generation as "silent" on the experience of the Internment. She quotes Nagata's finding that "forty per cent of the American Sansei in Nagata's survey indicated that their information about the internment came primarily through overhearing conversations or from outside sources..."22 in comparison to her own finding that "strikingly little communication occurred between the Sansei and their parents regarding the internment." 23 She does not attend to Nagata's finding, earlier cited, of the sixty per cent who did report learning of the Internment directly from a parent. Nor does she mention Nagata's conclusion that most of the Sansei in her study reported being 
affected by the Internment. In fact, even though she constitutes how her respondents describe their parents' various communications and non-communications about the Internment as characterized by a "high degree of silence and concealment,"24 Makabe concludes, "For the Canadian Sansei the internment seemed to have had little bearing on their upbringing.... Generally, they seemed unaware of the enduring effects of the internment or its significance on the individual as well as the group."25 Given Makabe's use of Nagata's work in supporting her construction of the Nisei as "silent" on the disclosure of the Internment to their children, it is curious that she does not interrogate the discrepancy in her finding that the Sansei in her study did not report being affected by the Internment, as compared to those in Nagata's research who overwhelmingly stated that they were affected by the incarcerations in the United States. This non-interrogation of her conclusion as to the lack of effect of the incarcerations upon the Canadian Sansei generation is evidenced further in her use of representational work on the Internment authored by Sansei. Makabe cites the work of many Sansei who have represented the Internment in various ways (for example, Norm Ibuki, Audrey Kobayashi, Cassandra Kobayashi, Bruce Kuwabara, Art Miki, Roy Miki, Maryka Omatsu, Terry Watada, myself, and others) and whose cultural production utilizing imagery and discourses related to the Internment is in addition to the works produced by other Sansei, such as, David Fujino, Michael Fukushima, Bryce Kanbara, Kirsten Emiko McAllister, Scott Toguri McFarlane, Peter Takaji Nunoda, Baco Ohama, Linda Ohama, Haruko Okano, Midi Onodera, Kerri Sakamoto, Gerry Shikatani, Rick Shiomi, Aiko Suzuki, and David Suzuki. ${ }^{26}$ I would argue that the work generated by Sansei utilizing Internment discourses attests to the profound effects of the Internment on these cultural producers as they seek out multiple means of understanding and expressing their understandings of the Internment. Yet Makabe's juxtapositions of quantitative research (her reading of her respondents as not reporting being affected by the Internment) and representational work that attests to the effects of the Internment upon various Sansei, and her usages of them are not problematized in her conclusion that Sansei "seemed unaware of the enduring effects of the internment."27

While Makabe's respondents raise interesting issues and in fact contradict the uniformity imposed through the study's methodological paradigm, her inclination to 
categorize the subjectivities of children of Nisei who were incarcerated under the unified rubric of "the Canadian Sansei" circumscribes her engagement with these contradictions.

My critique of Makabe's study on the Sansei reflects my concern regarding Internment discourses (and other representational work on Japanese Canadians) that serve to consolidate notions of racialized uniformity. Informed by Foucault's concept of “genealogy", my project seeks to develop methodologies that interrogate totalizing discourses of containment. As Foucault explains:

It is not therefore via an empiricism that the genealogical project unfolds, nor even via a positivism in the ordinary sense of that term. What it really does is to entertain the claims to attention of local, discontinuous, theory which would filter, hierarchise and order them in the name of some true knowledge and some arbitrary idea of what constitutes a science and its objects. ${ }^{28}$

It is the ways in which the institutionalization of knowledges through various disciplinary categories (such as history, sociology, English literature, psychology, feminist studies) limit investigation that have been raised as epistemological concerns in this thesis. It is ultimately the "effects of the power of a discourse" continually call attention to in relation to Internment narratives and the construction of Japanese Canadians. Through an analysis of some of the spaces of production of knowledge of the Internment, I would also hope to interweave the threads connecting my own interdisciplinary approaches to understanding how women constitute themselves in relation to the Internment. Hence my spatialization of the Internment and its connection to the production of remembrance and forgetting is also about calling attention to how the spaces of the "physical, mental, social" 30 get "held apart through fragmentary disciplinebased analyses." ${ }^{31}$ And further to this intent is my desire to contest totalizing discourses that serve to contain the very subjectivities of Japanese Canadians and to underline our "enunciative responsibility" 32 for discourses that naturalize this containment.

I will make two points in calling attention to the "effects of the power" of the discourse of silence before I commence my genealogical interrogation of the construction of knowledges of the Internment between mothers and daughters in my study. First, as I have been stating throughout this thesis, I consider the trope of "silence" mapped onto survivors of the Internment, as a site of containment. Clearly many writers, including 
Nagata, use this trope to stand in as an explicit sign of the difficulty of speaking about the Internment and the psychological trauma resulting from unjust incarceration and forced displacement. As was apparent in Paul Kariya and his sister's description of their father in Chapter Two and is also evident in Nagata's work, "silence" is an encoded word for multiple articulations ("they described the internment camps but not their feelings," "they described the incarceration but not the politics of the government," etc.) and nonarticulations, but somehow even speech is often reductively described as "silence" and somehow lacking.

As we have seen, Internment discourses circulate within a "political field of signification," 33 saturated by historical and interlocking constructions of race, gender, sexuality, class, physical and mental ability. Words such as "silent" and "reserved" used by white people to describe Asians have been mobilized to conjure up notions of their "inscrutability" and "passivity." As I have previously argued, these overdetermined signifiers are used as discourses of othering in service to universalizing the speaking white Western subject as a superior binary to the "silent" Internment survivor. As Laura Hyun Yi Kang reminds us, this binary construction between the Western subject and what is construed as the "Asian subject" is also one that is markedly gendered where the "Asian female has been a recurring figure of silence, passivity, sexual mystery, exotic inscrutability in this tradition of myth-making and identification." ${ }^{\text {"34 }}$ This racialized engendering of the Asian woman also enables particular constructions of the Asian man and while males are not exempted from the mark of silence, it is frequently the woman who is called upon in various representations to carry the trope to its foregone conclusion. Through this gendered hierarchy of visibility, the binary is also used to maintain the axiomatic heterosexual construction of the Asian female as "available" 35 to a hegemonic Western masculinity.

Under the lens of the Western gaze, Japanese Canadians continue to be the site of surveillance, knowable through their "speech" and "silence." Even in the ambiguity of this "silence" there is a way in which its usage becomes totalizing, serving to fix the racialized other as "knowable." To admit fluidity, ambiguity, contradictoriness in the "Other" might threaten the necessary fixity and normalcy of a hegemonic white bourgeois subject position. Yeğenoğlu's comment in relation to the white gaze and its fascination 
with and pathologizing of the veil wom by Muslim women might be aptly applied to the construction and mobilization of the "silence" trope. She states, "it is irrelevant in this sense whether there is "nothing" or "something" behind [the veil]. What is important is the fact that the European subject is able to secure his identity through this supposition or through...this imaginary anchor." 36 At a psychoanalytic level, there is possibly something that the white subject finds as "unsettling and terrifying" 37 in this "silence." The terror might be that the undoing of the "silence" entails admitting one's own participation in and dependence upon its construction and revealing one's own complicity in the legacy of violence. In these remarks, I am particularly interrogating the usages of these discourses by people who are not survivors or members of their families and the ways in which their own relationships to the Internment remain uninterrogated while they unabashedly circulate these repetitive discursive tropes. Even where the inscriber of Internment discourses is situated as "Japanese" or Japanese Canadian/American, "enunciative responsibility" should be assumed through problematizing our relationships to the subjects of our work. While the space of circulation of our representations may be construed as an undifferentiated space of the Canadian nation. our work mediates multiple spatial locations, most importantly the spaces inhabited by the subjects of our work. Additionally, we are writing from different social spaces and forwarding certain notions of social space in our work. Perhaps, if we begin to address our spatialized social locations and hence our own multiply constituted subject positions, we may be able to admit the heterogeneity of the subjects we claim to represent.

Hegemonic raced and gendered discourses of "silence" also impinge on the ways in which survivors and their children construct themselves. The spaces of re-imagining the Internment are not discretely separate from those where the Canadian nation is imagined for us and children of families who were incarcerated must negotiate our knowledges of the violence while occupying various spaces of remembrance and forgetting. We must also continually negotiate our own subject positions in relation to the hegemonic Western subject and what we know about how hegemony is secured in Canada.

It is interesting to note that none of the women I interviewed used the term "silent" to describe her parent(s) in relation to conveying memories of the Internment. All 
of the daughters I interviewed reported feeling profoundly affected by their families' histories of incarceration. While my thesis does not analyze all of the effects of the incarceration as interpreted by the daughters, my examination of how daughters spatially acquire knowledge about the Internment reflects how part of its long-term effect is the very constitution of spaces where Japanese Canadians currently live.

Just as their mothers struggled to describe their experiences of incarceration. each daughter struggles to name how she acquired a knowledge of her mother's incarceration. I would offer that what gets discursively reduced to the "silence" of our parent(s) is really about what cannot be named because Canadian violence-specific language fails them/us and because we continue to live in the nation space where our parent(s) was/were incarcerated; what cannot ever be named is the enormity of the violence of the Internment and how this violence was critical in the making of the Canadian nation. And while the notion of psychological trauma is important in understanding the difficulties in remembering the details of the Internment and speaking about them, the focus upon the trauma must not occlude the source of that trauma as being violence that was sociallyorganized and sanctioned by the state.

This leads me to the second point of concern. As is clear from my own need to return to interrogate the usages of the trope of silence throughout my thesis, I am haunted by its iterations and disturbed that its source is most commonly attributed to survivors alone. Just as I feel the trope of silence contains the violence. situating the source of this "silence" within the survivor herself is also an act of containing the violence and obfuscating the multiple complicities in the accomplishment of that violence. Attributing the ambivalence experienced by children to the "silence" of their parents obscures how racialized and gendered children must negotiate knowledge of violence experienced by their parents and themselves in multiple spaces of forgetting.

If, as I have previously argued, spaces are interconnected through social relations then the delineation of the parent-child relationship as the only site responsible for knowledge transmission of the Internment is a conceptualization that denies the critical interrelationship of various spaces in the formation of subjectivity. The spatial isolation of survivors as the conveyor of knowledge of violence is part of the way in which collective responsibility for that violence is continually forgotten. The inclination toward 
situating the responsibility for remembering and forgetting the Internment solely in the space of the parent-child relationship is therefore part of the process of producing a collective forgetting of the violence promulgated by the nation and its citizens. The continual resituating of the causes of children's lack of knowledge about the Internment as due to the "silence" of their parents, rather than the processes of forgetting the violence of nation-building, also serves as a technology of "othering" and a means of extending surveillance of survivors' behaviour to include their children and thus to what is construed as "the Japanese Canadian family." It is a gesture that reinscribes the hegemony of a particular family form, minimizing and invisibilizing the ways in which family and community connected to the parent-child relationship are also critical participants in producing the remembering and forgetting of the Internment. Hence, in situating the cause of the "silence" about the Internment within this dyadic space, we discursively repeat the process of separating survivors and their children from a larger familial context and community, a process seen in previous chapters as part of the violent incursion of the Internment itself. And the memories of that violence are relegated to the survivor alone to manage and communicate.

This relegation of knowledge production on the Internment to a particular dyadic relationship also illustrates how critical space is to an analysis of transmission of this knowledge. As we have seen in the previous chapters, a space may be constructed so as to obfuscate its relationship to other spaces and this is what I believe to be occurring in the discursive construction of the "silence" of Internment survivors. Situating the cause of not knowing about the Internment within the site of the parent-child relationship occludes how power operates in other sites and impinges upon our abilities to know and to name. What this spatial isolation disguises is how other sites of our existence are inhabited by people who are silent about the Internment. Imagining the familial space of "silence" also serves to bolster the notion of a binarily-imagined space where subjects speak freely. Again, the liberal notion of "freedom" works in concert with that of "equality," implying that all spaces are equal; some people just "choose" to be silent within them. If speaking is relegated merely to "choice," then one need not examine the relations of power that impede speech in the service of producing dominant narratives. 
In the next section, I will examine how women produce knowledges of the Internment within the spaces of family and Japanese Canadian community. How women describe transmission of the Internment history in these particular spaces will be the focus of this section.

\section{Section Two}

Spatializing "Handing Down" of

Knowledge of the Internment

The concept of "transmission" (or what I call "handing down") of historical trauma is useful in examining the long-term effects of the Internment across generations. In contrast to the work on psychological transmission, however, my project seeks to understand how knowledge of violence, in particular that of the Internment, is socially constructed in different spaces and how these spaces enable or disable the production of this knowledge. My work does not, therefore, focus upon the psychological effects of the Internment; it is not an evidentiary search for pathology. I seek instead to illustrate some of the ways in which survivors pass down knowledge of the Internment and how these memories constitute subjugated knowledges and can be used by survivors and their daughters to contest domination. It is through this Foucauldian methodology of "genealogy" that I hope to "establish a historical knowledge of struggle," as demonstrated by mothers and their daughters in relation to the Internment, in order to illustrate how we might "make use of this knowledge tactically today." 38

In this section I will examine the spaces of family and the Japanese Canadian community as sites of production of remembrance of the Internment for daughters of families who were incarcerated. I have previously argued that spaces are interconnected through social relations and that all of these interrelated spaces are producing the nation. My analysis does not intend to mark off "Japanese Canadian spaces" and "white spaces" as discrete and separate. My work seeks to illustrate how women negotiate these spaces and their overlappings in relation to their knowledge and their seeking of knowledge on the Internment. We shall witness how women describe these different spaces in relation to what knowledge of the Internment was acquired in each site. In this way, I hope to illustrate how a spatial analysis might assist us in understanding how knowledge of the 
Internment is multiply articulated and also actively denied and forgotten in particular spatial settings.

I will illustrate how the trope of silence is inadequate in describing the complex processes of the handing down of this history. Rather, the family is a site where women actively struggle for this knowledge transmission and production.

\section{Handing Down Memories of the Internment in the Space of Family}

As I discussed in section one, the site of family becomes the site of surveillance in the reiteration of survivors as silent about the Internment in interactions with their children. In the spatial isolation that is produced through the dyadic construction of this "family" as parents and children only, the parents alone are held accountable for managing and communicating this knowledge of the violence appropriately. Feminist studies on violence name the family as a potential site of violence for those in subordinate social positions, such as women and children. ${ }^{39}$ While recognizing this work. I would emphasize that my project seeks to call attention to how the notion of "family" is discursively constructed in relation to the Internment. Women of colour struggle to create safe spaces in which to live as we resist multiple articulations of power. There are different ways of naming this social organization of space and relationships: any form that reifies domination must be contested. How Japanese Canadian women negotiate male domination within the family is an area for further study. The issue of violence occurring within families is also one which has received very little attention.

In this section, I would like to recognize how survivors of the Internment have to manage the memories of the violence they experienced and witnessed and how their family spaces become one space of negotiation of this violence. The family space also becomes a space for negotiating the violence of systems of domination, including that of everyday racism, ${ }^{40}$ sexism, heterosexism, ableism, and class oppression. As was stated in Chapter Seven, my work seeks not to reify a Japanese Canadian family form but, in fact, hopes to illustrate that multiple kinds of relationships built with supportive communities offer possibilities for producing knowledge about violence and for contesting it. By holding survivors alone accountable for living with the memories of the violence of the 
Internment and communicating them appropriately, the importance of communal support is denied and the exclusionary hegemonies of an "autonomous" space is recreated through a forgetting of our own complicities in the violence done to others in the making of the Canadian nation. I believe that the family acts as a critical space in re-enacting memories of the Internment, and can be a "counterspace," to the other spaces inhabited by survivors and their families where resides a resounding silence on the Internment and other forms of national violence.

In Chapters Three to Seven, we witnessed some of what was taken away from women through processes of dispossession, incarceration, and displacement. Haru describes how her parents owned little but they did own secondhand furniture, which would now be "nice antiques," because they were "old to start with." $\$ 2$ Haru's description led me to wonder, as she did, where those "antiques" are now. In this way, the "antique" for Haru symbolizes what she cannot materially hand down to her children but what has become the inheritance for people who benefitted from her family's expulsion.

May explains the processes of dispossession and remembering the dispossession in this illuminating way:

I think most people, certainly a lot of people, left things behind they really felt they would retrieve at some point. Otherwise you would have brought a lot more things. I really think they felt they'd be able to retrieve them, which of course, most of us couldn't. So there are pieces of family history that are certainly lost. Where a lot of my friends here can say, "Oh I have my mother's plate or I have a wedding gift of my mom and dad's," you know, these things. They're simply in your memory. They're locked in your memory. And they're not there for you to be able to have or to hold onto or pass on. And so those are some of the things that are hard to put up with. ${ }^{43}$

Whethe- "antiques" or "Japanese dolls" or "boats" or "property," these possessions symbolize what has become inherited by others through our dispossession. The normalization of this dispossession - not to question how one becomes entitled to own what belonged to others or how we benefit from others being dispossessed - leads one to ultimately question who inherits the land and the nation and how is this inheritance acquired? The women $I$ interviewed have recounted their losses and while they cannot hand down these lost possessions, they do instantiate some memories of what and who were lost so that we may remember. If we can see how the various spaces of our 
dispossession, beginning with that experienced by Aboriginal peoples, contrapuntally produce the nation space, perhaps we can use our memory of our losses to imagine the nation differently.

\section{Handing Down Memory of the Internment}

Mayumi, Ann's daughter, was born in 1953 in Toronto. She describes how she learned about the incarceration of her parents in this way:

I think I was about twelve or thirteen. But I'm not positive. It just seems something that I've always known, but didn't...I've always sensed that, maybe from [family] pictures that I've seen, but I can't remember a particular moment where it suddenly all fell into place. I do remember being totally grossed out because the picture I had in my mind of it was somebody knocking on the door and handing them a duffle bag and saying. "That's all you can bring. You can fill a duffle bag and you have twentyfour hours." And I might have got that from my aunt or from my father, not from my mom. ${ }^{44}$

In her testimony, Mayumi raises three aspects that I will continue to explore in this section in connection to my methodology of spatializing the knowledge production of the Internment. First, she raises the importance of imagining the spaces, both in thinking about the "knock on the door" and the order to leave in twenty-four hours, and the technology of photographs as somehow being linked to her accumulation of knowledge.

Secondly, she underlines that it was not from her mother that she learned about the "knock on the door," but it was from her aunt or her father. Third, there is the "it" that stands in for what cannot be named, that I have reductively collapsed under the inadequate term "Internment," a "gap" in our language reminding us of the difficulties in naming. These three elements: the importance of space in knowledge production; the importance of family, extended family, and community in accumulating knowledge and analysis; and the struggle to name what cannot be named will be examined throughout this chapter.

Midori, who was born in a prairie province in 1968, is S.'s daughter. She also describes her accumulation of knowledge about the Internment as "gradual" and told to her in the form of "stories" recounted by both her mother and father. She states, "I don't 
remember a point where all of a sudden we were told about this thing.... My dad tells us more stories than my mom. 45

Yuko, who was born in Toronto in 1955, is Haru's daughter. The Internment for her was never "something that was ever discussed" with her mother or father. She states she never had a conversation with her father about the incarceration before his death. ${ }^{46}$ But she also remembers hearing her parents talk during the redress struggle about "Vancouver and going to Hastings Park." "77 But she explains, "it was like I heard about I but I didn't really listen." ${ }^{48}$ It was only after Yuko went on a tour of the B.C. prison camps that she "talked a little bit" with her mother about the incarcerations.

Born in 1969 in northem Ontario in the town to which her family was forced to move, Naomi, Yoshiko's daughter, associates being in Vancouver with her first awareness of the Internment. She moved when she was a year old from Ontario to rural B.C. and then to Vancouver, and it was in this city that she remembers her mother getting involved in a Japanese Canadian community project. "That was the same time we became aware of it as something in my mother's life," she states. ${ }^{50}$ Naomi also comments that she can't remember her mother talking about having to move, but she can remember her describing "what it was like to be a kid in the camp." Yoshiko had reported in her interview that she could not remember anything about her move from Vancouver. The gap in memory remarked upon by Yoshiko is handed down to Naomi, although Naomi may not be aware that it is lack of memory that accounts for this gap. Naomi also spatializes her development of awareness of the Internment within the space of Vancouver and in relation to a Japanese Canadian community and her mother's participation in that community.

Eiko experienced the continuing displacement of her family as her parents moved to British Columbia to assist her grandparents in setting up a business. Born in Toronto in 1951, Eiko moved at the age of four and lived in British Columbia for approximately four years. She explains, "After the war, grandpa, my dad's dad - you know, none of the property or anything was ever returned - decided to...stan a [business]... and he needed my dad's help." 52 She describes learning about the Internment "incidentally" from both of her parents and never as a "conscious sit down and we're going to teach you this because you need to know it." 53 
Kyo, Louise's daughter, and Aya and Ann's granddaughter, was born in Toronto in 1970. She attributes her first awareness of the Internment to the discussions in her family regarding redress. She was a teenager at the time and remembers being at her grandparents' home where family members were discussing compensation. She states, "I think I just listened. And I picked up a lot of things from just listening." 54 This accumulation of knowledge about the Internment came for her "in bits and pieces as they talked about it more and more in terms of what the government was doing." Hence within a family space constituted as including grandparents, Kyo became aware of the incarceration of these family members.

Kyo also emphasizes the spatial dissonances realized through the telling of her mother's stories about "camp": "At one point they were living in a house with running water and electricity on the west coast; my grandfather had a car and a boat. And suddenly they were in these shacks without [electricity]." 56 These contrapuntal spatial images raised for her the question, "Who decided this?"57

In both Yuko and Kyo's situations, redress was a pivotal moment in their learning about the Internment within their family spaces. The mobilization of a particular configuration of the Japanese Canadian community therefore influenced and supported these families' abilities to speak about the incarcerations within familial settings.

Sylvia remembers first learning about the "events" of the Internment from her cousin with whom she was very close. Born in 1958, Sylvia grew up in Toronto. She describes how she knew "a little bit about it as a child." 58 She adds, "Not that my parents volunteered very much information about it or spoke about it at all." 59 When she was a teenager she began to ask her mother and father questions. But she recalls "they'd say they couldn't remember and they wouldn't give many details. " 60 She also adds that her mother was "more reluctant to talk about it than my father." 61 Sylvia states that her cousin was pivotal in developing an understanding of the injustice of the Internment. She describes the awareness that "it was wrong" as being a gradual one. Sylvia also heard things told to her by her cousin's mother and also "to some extent [her] mother."62 Janice, Esther's daughter, grew up in Vancouver and was born in 1965. In describing how she acquired a knowledge about the Internment, she states: "I always had a sense that I always knew. It was never a secret in our family.... It was just part of their 
lives. ${ }^{63}$ Her description of how she learned about the incarceration of her family on a sugar beet farm spatially constructs her family as including all of her mother's sisters and brothers who attended their Sunday "family dinners." She adds that she had always known her family had lived in Manitoba and at their regular dinners, they would refer to being "in the beet fields" and "they' $d$ always talk about people they knew, and some of the people were from [Manitoba]." Janice remembers the emphasis in the conversations was returning to Vancouver, "when we moved back." 65 As in the case of Kyo and Sylvia, family space for Janice includes people outside of the dyadic construction. Her aunts and uncles all conveyed information about their working on the Manitoba sugar beet farm. Janice's mother was an active participant in these conversations and her father, who is white, was also present when these discussions occurred.

Joanne, Evelyn's daughter, was born in 1963. She also describes how accumulating a knowledge of her mother's incarceration in Lillooet was a gradual process. "I don't think there was a point of shock or realization," she states. "I think the knowledge was always integrated. But the meaning of it and the weight of the meaning grew with time." 66 Joanne also talks about her extended family, gathering at her grandmother's home, and it was in creating this space that her elders were able to talk about their incarceration in Lillooet.

Joanne's uncle talks about her grandmother's Japanese dolls and how "they're all gone now." 67 He has told her, "We had lots of boats." 68 When she asked him whether he misses fishing, he replied, "There's nothing like being out in the boat and bringing in fish, the smell of the sea, out there in the ocean. We'd dry fish and cook it." 69 Joanne's aunt sometimes expresses "great sadness and loss."70

Irene was born in Toronto in 1959. She also describes how many members of her family informed her about the Internment. She states, "It was discussed and references were made to it throughout my life. It didn't occur to anyone in my family to hide it from us. This was their life as they grew up... [it didn't occur] to my Nisei aunts and uncles to hide it from us." "Space is also an important element in Irene's understanding of the Internment. Interestingly she describes how her mother "made references only to ghost towns" even though she had been incarcerated on a sugar beet farm. ${ }^{72}$ Irene's father, however, was incarcerated in a B.C. prison camp. "It wasn't until I was in my teens that I 
realized people went to different places. I think [my mother] made references to ghost towns because that was the general experience of Japanese Canadians." ${ }^{.73}$ She recalls her mother discussing this with her more than her father, but she would hear her aunts' descriptions of some of her father's experiences when they gathered together for monthly family meetings.

When I asked Irene how family members responded to her questions, she described them as being "very open. Almost pleased to be asked."74 An aunt asked her uncle why he hadn't told her a piece of information about his childhood that he had disclosed to Irene. He replied, "No one has ever asked me."75 Irene concluded, "There's all this information that no one ever asked him. It's too bad."76

When I asked Irene's mother, Margaret, whether her children inquire about her history, she replied that her son did not ask as many questions as did Irene. "I guess he's heard everything there is to hear," she surmises. "It would be an error to deduce from Margaret's observation that boys are less likely to engage in conversations about the Internment than are girls. What her testimony does suggest is that there are different witnessing practices occurring within the familial space. Family members have different relationships with the children in each family and this may produce differential knowledges even amongst siblings. This point was noted in the brief testimonies offered by the Kariyas in Chapter Two. Understanding spatialization in knowledge production would also be useful here; if gendered-divisions of labour and socializing occur within particular spaces, conversations taking place in these spaces may be accessible only if one is en-gendered to partake in that space and activity.

As we have seen in most of these examples, the family space is constituted as including members outside of the dyadic relationship of parent and child. This space of family had to be reconstituted after years of separation and displacement and is one way in which people resisted the total destruction of historical, communal interconnections. Naming familial members as "outside" of the family reproduces a hegemonic notion of "nuclear" family and discursively reinscribes the separations of family members that the violence of the Internment produced. The descriptions of family by these women also indicate the ways in which they reconstituted their families after their incarcerations. These spaces, where many family members gather, also may provide support for the 
discussion of memories of the Internment. In addition to the dyadic relationship between parent and child, these family spaces are sites of knowledge production for children.

As was pointed out to us by women in Chapters Four to Seven, we must also recognize that there were people "missing" from these reconstituted family spaces. Those absent from the family space could not contribute to the dialogic construction of memories of the Internment. Children in contact with few family members have fewer opportunities to learn about their family's history of incarceration.

Naomi, who lives in Vancouver, describes "having to buy a plane ticket to [a northem Ontario airport] and then having to get on a bus and go to [her grandmother's home], which was three hours away" in order to visit her grandmother. ${ }^{78}$ Although she would visit her grandmother as a child in the summer, they could not stay long. A recent trip to see her grandmother concretized Naomi feelings in this way:

It really made me angry that she lives there. I was making the connection to that being a part of this internment process. And I thought, I'm all pissed off that I have to [travel so far] and then I thought my grandmother lives there and has lived there for over fifty years.... I would not want to live [ $t$ ]here...my grandmother could be here, living with us and having more of a natural relationship with me and my mother and this whole city.... ${ }^{79}$

Naomi's grandmother has a few Japanese Canadian friends, people who were also forced to move to this northern town, but her absence from her daughter and granddaughter is marked by the long distance separating their family spaces. Naomi thinks the reason she can't speak Japanese is "a direct result of all of this" and "that's one thing that I'm really upset about." 80

While Naomi is able to speak to her grandmother in English, she raises the point of language, also raised by other women. Another example of how access to dialogue with multiple familial members about the Internment may be limited is exemplified through the relationships of some of the daughters to their Japanese-speaking grandparents. Here it is not a question of geographical distance but rather linguistic distances that affect communication.

We have witnessed the dismantling of the west coast Japanese Canadian communities through the incarcerations and dispersal. The destruction of those communities also entailed the devastation of their infrastructures, including institutions 
such as Japanese-language schools and community churches, the Buddhist churches in particular. Additionally, the demonization of any cultural associations with Japan was not the invention of a subordinated community, but were clearly part of the discursive foundation for its very incarceration and followed them as part of the mechanism of surveillance through their sites of dispersal. Given this context, it is not surprising that none of the non-incarcerated daughters I interviewed spoke Japanese as a child. One daughter later learned the language and lived in Japan to accomplish this goal.

Some parents feel that their children hold them responsible for this language loss. In Chapter Five, Yoshiko described how she felt she had to study the Japanese language under clandestine conditions in the Slocan prison camp. While she can still "converse to a certain degree" in Japanese, she feels her children are "so angry...that I haven't retained the language." 81 She explains how in northern Ontario. "it was not the thing to do." "I'm sure [my parents] must have struggled... in bringing up their children," she adds. ${ }^{82}$ "I don't have any occasion to speak it," she emphasizes in describing the geographical distance between her and her mother. ${ }^{83}$ She understands her children's anger and tries to explain to them the process of language loss by comparing it to the "colonization of Native people." She has told her children, "We were schooled out and educated out of [our] own culture, to be assimilated." 84

Language classes were eventually established by Japanese Canadian communities in some of the larger cities to which people were moved. Haru encouraged her children to attend and tried to bribe them into going with the promise of a soba lunch afterwards. Her children, however, did not continue to study at the school.

To hinge language transmission solely on the dyadic relationship of parent and child, once again, obscures the relations of power impinging upon survivors who had to contend with racism in the multiple white spaces to which they were sent. Forced to move from Steveston, where she could speak Japanese with her family and within a community, Aya explained how in living in Winnipeg, she learned English. "I feel more comfortable in Japanese.... Well the kids all spoke English so to converse with them I had to [speak English]."85 
Mayumi's mother, Ann, and her father "only spoke Japanese to each other" when she was a child. ${ }^{86}$ She knew her maternal grandmother who spoke some English. She adds,

I don't speak Japanese. And I think it's a very common trait for my generation. I think it was done so we could assimilate... But also probably because [language classes] weren't as readily available. But all my other friends went to after school classes for whatever language they [used at home]. ${ }^{87}$

Ann, Mayumi's mother, however, told me she spoke English with her own mother and that her mother learned to speak English "after," which I took to signify after they were forced to leave the west coast. ${ }^{88}$ Kyo can converse with her grandmother, Ann, in English but she wasn't able to communicate with her grandfather on a "critical level." 89

Irene's parents asked her whether she wanted to take Japanese-language classes when she was a child and she declined. She stated that her maternal grandmother spoke "quite a bit of English" but in their later years, both of her grandmothers needed to speak more in their first language and she couldn't communicate with them. ${ }^{90}$

Sylvia described to me how she never knew her paternal grandparents. Her grandmother died before she was born. She knows her grandfather only through photographs she has of him holding her when she was a baby. He had lived with them and died when she was very young. Her maternal grandparents lived with her uncle in Toronto. "I didn't know them well because they didn't speak any English. And I of course didn't speak any Japanese," she states. ${ }^{91}$ Although she describes how she knew that she loved her grandmother and that her grandmother was especially affectionate toward her, she emphasizes their relationship was "quite limited."92 She adds, "we never had conversations. And she died when I was, maybe in my early teens." 93 Her grandfather lived to be a 102 years old and she spent time with him, but she "didn't talk to him, didn't really converse."

Sylvia was aware of the rich life inhabited by her grandfather, a life to which she did not have linguistic access:

Even after the war, he was still in touch with other Japanese Canadians and he wrote haiku poetry. $\mathrm{He}^{\prime} \mathrm{d}$ meet in this little rundown house every Sunday afternoon with his poetry group. And they'd read and write and 
they in fact published a book. And I can't read it.... But he had all of those contacts....95

If we see the issue of language acquisition as one transpiring in the space of the parent-child relationship alone, we miss the relations of power that impinge upon what language is spoken by racialized people. Adhering to the model of the liberal subject, these examples get reduced to parents and children "choosing" to speak English. Mayumi alluded to the social limitations imposed upon families dispersed into white communities. Establishing Japanese-language schools within these spaces and sending children to these schools was another negotiation families had to make in a nation that had incarcerated them based on their discursive construction as foreigners. As we have seen in Chapter Six, women met with racism in the white spaces to which they were forced to move. As we shall see in the next chapter, their children were also the targets of racism in white spaces. Kyo reminds us that one of the ways in which Asian children and adults are racially attacked is through the ways in which white people make fun of Asian languages and approach us with their racist and defiling mockeries in the schoolyard and in other spaces. ${ }^{96}$ This everyday violence, used as a means of disciplining racialized people for their very bodies and cultural histories, influences their negotiations on how much more racialized space they feel they can create and occupy.

The 1951 Canadian Census described the "impressive drop" for people of "Japanese origins" unable to speak English or French from 12.4 percent in 1941 to 7.5 percent in $1951 .{ }^{97}$ Also mentioned within this context of illustrating "improvements in ability to speak official languages" were Aboriginal peoples for whom the percentages changed from 32.1 in 1941 to 25.6 in $1951 .^{98}$ The "population of Chinese origin" was reported at 24 percent in 1941 and 17 percent in 1951.99

What is seldom addressed in normalizing the loss of knowledge and practice of a language in Canada is the violence of that process. Reducing such a loss to "assimilation" obscures the processes through which the English language becomes the sign of normality and the violence required to ensure its dominant practice. While many of the daughters interviewed had multiple family members with whom they could learn about the Internment, this communication most often occurred in English. The materiality constructing this linguistic relationship must not be ignored, nor should those who are 
linguistically excluded from this exchange be dismissed as "silent." As we have seen through Naomi and Mayumi's testimonies, some of the daughters clearly attribute this loss of a language and the relationships affected through this loss to the Internment, part of its long-term effect in their lives.

With the loss of language came the loss of linguistic connection to relatives living in Japan. My work does not undertake an analysis of the complex relationships that survivors and their children have to Japan. It is evident that the incarcerations and the forced dispersal through the deportation scheme also produced conflicted relationships with the nation of Japan and for some the loss of a country of "origin." They also produced the "missing" of thousands of people through forced expatriation.

\section{Struggling with the Violence of the Internment and Everyday Oppression}

The space of family, as some of the women have alluded, is also one where the memories of the violence of the Internment must be managed by survivors. Daughters describe this negotiation in varying ways. Mayumi reports how she still doesn't "really understand what had happened." 100 She can't "get a picture of it" and she attributes this "gap" in her knowledge to her mother's description, what Mayumi pictures as a "resort," drawn from her mother's words that "they had a whole house to [them]selves." ${ }^{101}$ But she knew from a "gut reaction" that "somehow Japanese were second class." 102

Mayumi's niece, Kyo. also raised the same issue of her grandmother's reference to being able to live in a "house" in the prison camp because they had children and her self-description as "lucky." ${ }^{103}$ But she also states that her grandmother described to her having to live in a horse stall with her young children and that they also took her grandfather away. ${ }^{104}$ As I stated in Chapter Five and Chapter Seven, these juxtaposed descriptions of the spaces of incarceration with that of situating oneself within a "memory of community" may seem contradictory to survivors' children. These testimonial accounts are clearly complex negotiations of the violence visited upon the testifier through the Internment itself and a way of managing the representation of the violence to younger familial members. What is also evident from Kyo's account is that her grandmother has handed down some of her knowledge of the violence, but chooses not to impart the pain 
or affective response to that violence. Kyo comments that her mother also is able to talk to her about the "historical point of view.... But I don't think we've ever dealt with the emotional side."105

The "emotional side," however, may be expressed by other family members. As Kyo states, her great-aunt is "really bitter" about the death of her brother in Japan. ${ }^{106}$ Yet she has noticed that her grandmother "never talks" about his death. ${ }^{107}$ In this way, children who have access to many family members may accumulate different forms of knowledge about the Internment. Children who have fewer familial members with whom they are in contact may have more limited numbers of people to inform them about the Internment in the family space.

Clearly all adults have to negotiate whether to disclose the incarcerations' painful effects to their familial children and the responsibilities in living day-to-day with these negotiations may be more heavily felt by the parent(s). They may be less likely therefore to share the "emotional side" with their children than perhaps other relatives might be.

Access to her mother's sister gave Joanne insight into how another family member viewed her incarceration in Lillooet. Joanne described her mother's account of Lillonet as a "positive construction," whereas her aunt refers to being incarcerated as the "ruin of her life." 108 Janice remarked that she has not heard her family members say the word "racism." 109 Irene stated that family members described the Internment "more on a human level than the political issues." She explained this by saying she thought her family was "not political at all."110 And Yoshiko described how her father would sometimes talk about the "political conditions," and "what a shame" the good people he had known in Vancouver "weren't able to go to university" because they all had "that potential" in the pre-Internment period. "II Yoshiko adds that her parents, however, never talked about the "things that they lost." "12 Midori's parents would tell her stories but "they wouldn't al ways say exactly what the story was about." ${ }^{113}$ Her mother, S., explains how she and her husband have conveyed this history to their children:

They may not thoroughly understand what it was all about but they did know what we went through.... We never tried to...bring it up as a point of education or anything you should learn because we went through this. That's not the way we use it. As a matter of information we tell them. What they do with that information is up to them. But it's more from what 
they can observe themselves. And they know what we have been through. ${ }^{114}$

Despite Janice's recollection of the many ways in which her family's forced move to work on a sugar beet farm has been conveyed to her by different family members, her mother, Esther, speculated "[Janice] might tell you that it was something that just never really was discussed." 115 These dissonances between how women feel they are conveying/not conveying information about the Internment and how their daughters feel they have received/not received information are processes more complex than the description of a context of "silence" might suggest. That Japanese Canadians feel responsible and are held solely responsible for this engagement, especially by nonJapanese Canadians, denies how survivors live and struggle with the limits of what they know, remember, and feel they can impart to their children about the complex experiences of expulsion, incarceration, and displacement.

The age of a child is a factor in some parents' decisions to describe the events of the Internment or their analyses of them to their children. This kind of age-appropriate transmission of knowledge is not unique to the issue of Internment. However, given the violence that is inherently embedded within these "stories," parents who wish to manage their children's exposure to the violence must deliberate on what to tell them and how they should be told. Joanne described how her mother's family "didn't talk about it in terms of injustice," however, "those sorts of stories came later" when she was older. ${ }^{116}$ One of Ann's grandchildren interviewed her for a project, but she felt the young ones, "are not at the age to ask [questions] yet." 117 "I think that at one time or ar:other they should be told what happened," she emphasized. ${ }^{118}$

These brief examples illustrate how different women negotiate the communication of the violent experience of incarceration, displacement, and dispossession. Rather than describing survivors as categorically silent about the violence they underwent, perhaps we can begin to see how the familial space is actually one where complex managements of the violence are being continually struggled over and where the struggle to remember and hand down these memories is also a complex negotiation with the space of nation itself.

The family becomes a space of pedagogical strategy in relation to how the history of Internment is communicated. What does not get taken up in the portrayal of Japanese 
Canadians as "silent" about the Internment is how difficult it is to "speak" about the violence as it engages a complex negotiation with the trauma of the incarcerations and displacements, and the potentiality of traumatizing one's children through its recounting. I would suggest that what children describe as the "gaps" in their understanding of the Internment, the "silences" sometimes equated with "no speech," is integrally linked to the violence their parent(s) have experienced and witnessed. While survivors must continually manage their knowledge of violence within the family space, in deciding to hand down knowledge of the Internment they must consciously wrestle with how much of the violence of that experience they will reveal. I would submit that some of these "gaps" (for example, not expressing one's feelings about certain events, not giving details of certain events, emphasizing the "good" times) are attempts not to hand down the violence.

Roger I. Simon and Wendy Armitage-Simon have written about the pedagogical implications of what they call teaching "risky stories" of "violence, cruelty, destructiveness and suffering" to children in a school setting. ${ }^{119}$ While their analysis does not specifically address the position of children whose "risky" family story is being told (and I would argue these children are more at "risk" in settings where these stories are taught), their work points out some of the difficulties in teaching these traumatic historical narratives. These difficulties in teaching are even more pronounced within the space of the family where the processes of imparting traumatic information have not been given much institutional or intellectual support by the communities in which we live. What Simon and Armitage-Simon describe as "shadow texts," the "secondary narratives constructed in response to the unresolved questions a primary narrative elicits," ${ }^{\prime 20}$ is a useful concept in understanding the "gaps" and contradictory interpretations remarked on by the daughters above. They state, "all such disturbing stories will elicit attempts to write shadow texts structured by the ambiguities and emotional conundrums of risky narratives." 121

I use this work on pedagogical theory related to teaching histories of violence to support my understanding that the work of parent survivors in the family space is one of enormous importance and struggle, and one that should not go unsupported by the community. Nevertheless, they have been imposed with the daunting task of transmitting 
their knowledge of the Internment when there are many other spaces of our existence where we are not supported for its remembrance and even meet with the denial of its relevance. Given this juxtaposition of spaces of remembrance and forgetting, I strongly urge that we, as generations of the Internment, explicitly strategize on communal ways to support survivors with this task, and consider "pedagogic grounds" for ourselves and our children in "comprehending... and taking on the obligations that hearing or reading these stories require," within a "community that remembers." 122 Some strategies will be suggested in the conclusion to this thesis.

As Nagata has demonstrated, children also struggle with asking about the Internment within the family space. Yuko described the Internment as "almost like a taboo subject in some ways." 123 She spoke of how both she and her mother don't initiate conversations about the incarcerations, and said, "It's funny because I don't press it and she doesn't offer." 124 Naomi, whose grandmother lives in the northern Ontario town to which she was moved after being incarcerated in Slocan, described to me how she rarely gets to see her grandmother. Naomi now resides in her grandmother's former home city, Vancouver. The spatial configuration of their relationship is different from that of those who see familial members on a regular basis. Naomi explains,

To this day, I haven't talked to [my grandmother] about it.... This is not something that you just lightly [ask about]. It's not a casual issue...I'm sure that I could talk to her about it. But I feel I have to learn a little bit more first and be aware of a lot more things before I feel confident and comfortable in doing that. ${ }^{125}$

With an awareness of how conversations regarding the Internment may affect their family members, some daughters take great care in how they think about initiating these discussions within the family space. Just as parents develop mechanisms to cope with the violence they experienced, children also develop strategies for witnessing the legacy of violence in their own families. While much has been written about the "interpretation" of the behaviour of survivors of the Internment as demonstrations of "shikata ga nai," "silence," etc., little attention has been paid to how their children have been part of this social construction of their parent(s) and do so from very specific subject positions. For reasons of interlocking social positionalities (class, race, gender, ability to speak and write English/French), most representational work on the Internment and its subjects have 
been authored by Japanese Canadians who were not incarcerated or by non-Japanese Canadians, and not by survivors themselves. As I have mentioned in Chapters Two and Seven, I believe the presumption of a liberal humanist subject is often informing “interpretations" of survivors' testimonies. I have also found "reading" these interpretive accounts "against" the liberal humanist subject a means of interrogating totalizing discourses of containment and the positions of domination embedded through our undertaking of representation through the production of cultural texts.

I would, however, also forward the notion that just as trauma induced by the violence of the Internment is informing survivors' abilities to communicate this experience to others, trauma is also informing our interpretations of these testimonies. As Simon and Armitage-Simon have noted, "risky stories" can profoundly affect children exposed to them. While some analyses of the effects of representations of violence upon children and adults point out how witnessing this violence challenges one's view of the world as "meaningful and orderly," 126 I would suggest that this view of the world itself must be problematized if we are committed to challenging domination. This would inevitably entail examining whose world view is represented as "meaningful and orderly," and how we are differently situated in relation to this representation. I would submit that this view of the world is connected to how we imagine the nation as a space of benevolence. Yet children live the contradictions of this imagining as it is continually contested from the space of a family who has undergone unjust incarceration and displacement. The psychological notion of "secondary victimization"' 127 may be useful in acknowledging how survivors' children hear and read testimonial accounts and representations of violence. I am troubled, however, when a term like "vicarious traumatization" 128 is applied to all witnesses to accounts of violence if its usage does not also include an analysis of how we are positioned differently in relation to the particularization of the violences we are witnessing and how positions of domination construct our own complicities in a world imagined as being "meaningful and orderly." While I cannot attend to the issue of the psychological effects of the Intermment on children of survivors, I would emphasize that their struggle to articulate and manage the consequences of violence within their families is evidence of the profound long-term effects of the violence. 
As was earlier stated, this management of violence also includes the everyday forms of domination to which family members are exposed. In contrast to Makabe's conclusion that "[The Sansei] do not perceive discrimination as a problem and thus do not conceive their ethnic background as having ever been an obstacle..."129 all of the daughters I interviewed reported they had experienced racism. These racist incidents occurred in multiple spaces from British Columbia to Ontario. While I am unable to explicate these incidents in detail in this project, some of them will be mentioned in the next chapter. What I am emphasizing here is how the family is the space where experiences of violence outside of the family must be struggled with and is also the site for strategy-building and resisting.

In Joanne's case, she did not wish to describe these incidents to her parents when she was a child because she felt they were "too shameful" and "too embarrassing." 130 One vivid memory she has is of a white boy, whose mother owned a major company in their town, verbally abusing her. She also considered her mother's feelings in not disclosing these experiences, "I couldn't relay something so cruel that might hurt her.... So I took it upon myself."13!

Sylvia also described how she did not tell her parents when she was called antiJapanese names at school because she "thought it would hurt them." 132 She was strongly aware of her father's "very strong feelings about racism," and had seen him verbally assaulted by white people. When she concludes that for her "one of the damages, one of the wounds," of the Internment and of racisin was not being able to talk about it, she also situates the inability to speak spatially. ${ }^{133}$ Due to the dispersal her father, in particular, was isolated from Japanese Canadian friends to whom he could speak about his incarceration and racism. Subjugated knowledges of the Internment are conveyed in multiple visceral forms and Sylvia's father's protests at the racism directed at him was one way in which he conveyed his understanding of the Internment and his place in nation. By situating their lack of discussion about the harms of the Internment and racism within a white community where such speaking was disallowed, Sylvia emphasizes that support is necessary when confronting the harms caused by violence. A contributing harm is when the violence itself is denied by non-Japanese Canadians. 
Naomi described the family space as one where they discuss the racism they experience, but she feels that these discussions preclude their discussions of the Internment. She states:

We talk about [racism] a lot with each other and with my sister. It's ironic that we talk about issues like racism and how she experiences that in her work and how I experience it at school...but we don't specifically talk about the internment. It's this whole idea that it's past. But that's like the root of it. That's a really fundamental part of my mother's history and my grandmother's history and my history. And yet it's unspoken. Whereas these other things, they're happening in our lives now so...that's what we talk about. ${ }^{134}$

In the next chapter, we will return to Naomi's comment, "that's the root of it," to understand how conversations or activities that do not specifically speak to the Internment may be conveying this history in multiple ways.

We have seen in this section how the family is a space of struggle over how knowledge of the Intermment is produced and communicated. In the next section, we will see how different "technologies of memory" are used to further the knowledge of the Internment.

\section{Section Two:}

\section{Spatializing the Internment Through Photographs}

Joanne, like Mayumi, talks about using photographs to visualize the multiple spaces of her family's life before, during, and after the incarceration. It was these shifts in place and the different meanings construed from these displacements that are critical in imagining the Internment and in understanding it as a life-affecting and violent experience.

Joanne states, "Through...different uncles and aunts at family gatherings, different stories [were told] when we would be asking about the photos. Mom would talk about having to go to school in a tent." 135 Joanne explains how the photos at her grandmother's house were a vital visual aid. She remembers looking at the photos when she was a child and seeing her mother's life in Vancouver conveying "a sense of beautiful clothes, house, different activities, like going shopping and running freely around Powell Street." 136 On the other hand the photographs from Lillooet and her mother's description 
of it conveyed a "sense of the tent schoolhouses, having to pick tomatoes.... While it was adventuresome, there's this sense of a desolate landscape."137

Thus technologies that assist in visualizing, imagining, spatializing the sites of incarceration and displacement seem to be used by some survivors' children in understanding the meaning of these events. Marita Sturken refers to these objects, images, and representations as "technologies of memory" that are not passive "vessels of memory," but are "objects through which memories are shared, produced, and given meaning." 138 Using Foucault's definition of "technologies" as "social practices," Sturken emphasizes that technologies of memory are "inevitably implicated in power dynamics... [and] are also practices that people enact upon themselves."139

As well as Joanne and Mayumi's descriptions of using photographs in this way, Janice and Kyo also referred to how photos enhanced their understanding of the Internment. Janice states, "We always had photo albums. They took a lot of pictures when they were on the sugar beet farms." ${ }^{40}$ As did Joanne, Janice situates her understanding of the hardship of the beet farms in comparing the photos her mother has kept from her parents' duties as baishakunin to the photos taken on the sugar beet farms. "You have the real working photos of them in the fields. And then you have these really beautiful glamorous studio wedding portraits of all these people we don't really know. You can see my grandpa and grandma in [all of these photos]." 141 These photographs were always accessible to Janice within her familial setting and in this way served as a continual technology of memory, commemorating Janice's grandparents, as well as the shifts in place and social relations that the Internment incurred. "I remember always looking at those and my mom never put them away. You could always pull them out and look through them all the time. So I always knew that they'd lived there and moved back." 142 Janice's mother, Esther, offered to show me family photographs at the end of her interview (although time precluded this engagement), reinforcing how photographs are used in their family to enhance knowledge production.

Kyo actually showed me a family photograph during her interview. While talking about her paternal grandmother, Ann, she used the photograph to describe what had happened to the various members of the family as a result of the Internment. Kyo used the photograph to describe how separations of family members occurred; she also used it to 
describe the death of her grandmother's brother who was in Japan during the war. Like Joanne and Janice, in using this technology of memory, Kyo is able to reconfigure a preInternment family space. In Kyo's case, through information provided by her grandmother and through other family members, and by juxtaposing this knowledge to the fact that her grandmother's sisters now live in two different Canadian cities, she also gains an implicit understanding of the violence of the Internment. These effects of the Internment are communicated in her interview as the knowledge she has acquired to date, including the information that her great-uncle died, something about which she describes her great-aunt as being "really bitter." ${ }^{43}$ This "bitterness," she reports, is also related to the fact that her great-grandfather was a Canadian veteran of World War II. In this complex reconstruction of familial memory as handed down to one family member, Kyo uses the photograph to produce her own understandings of the effects of the Internment upon her family and she also uses the photo to visually transmit this knowledge to me. In this way, she enacts an embodiment of the memories handed down to her and uses the photograph as the "substitute for the body" of all those represented through its image, using this technology to "engage in relation to social institutions and practices" promulgated through the Internment. ${ }^{144}$

Yoshiko, who was incarcerated in Slocan, also spoke about the importance of photographs in her continuing development of knowledge on the Internment. She referred to knowing that her family had been dispossessed of family items, such as Japanese dolls, through looking at photographs (see Chapter Four). These photographs were located in their home, and while she describes her parents as "never talking" about the Internment, she states that when she was older, she and her siblings would ask questions about "the things in the pictures and then they would talk about people.... It was wonderful, everybody becomes alive through the pictures. So that was where we got most of our information about people." ${ }^{145}$ As I earlier stated, survivors, as well as being involved in a process of knowledge transmission, are also engaged in acquiring knowledge from various sources and this production of knowledge and transmission is therefore constantly shifting and cannot be fixed as the trope of "silence" suggests.

Yet given the government's policy of confiscating cameras at the outset of the expulsion, ${ }^{146}$ many people may not have photographs as documentation of their spaces of 
incarceration and displacement. Many photographs from the pre-Internment period, including those taken of relatives in Japan, were also lost in the forced movement from the coast. Photographs depicting the history particular to one's own family, therefore. may not be available as a technology of memory. But perhaps this lack of familial images may also convey another sense of loss through absence and the violence of that loss.

\section{The Critical Function of Representation in Spacializing a Knowledge of the Internment}

Yoshiko's daughter, Naomi, also mentions the importance of "trying to get some images" about the Internment and watching films on the Holocaust to try to imagine what "prison camps" were like. ${ }^{147}$ She remembers a picture from a book on the Internment depicting a "group of women" in a prison camp. ${ }^{148}$ This left her with the image of the interior camps as a space "where there were lots of women and children." ${ }^{149}$ She also connects this image to her knowledge that her mother's father was separated from the family and sent to a work camp. The memory of the one photo of women in conjunction with the information that her grandfather was separated from his family is used by her to imagine different spaces of incarceration and how these separations were embodied in her family.

Both Joanne and Kyo specifically mention the use of the book, A Child in Prison Camp by Shizuye Takashima, ${ }^{150}$ in expanding their comprehension of their mothers' incarcerations. Joanne stated that her mother gave that book and others to her and her siblings: "I knew those books were about... what she and her family went through...Takashima's book was another way for us... to imagine Lillooet."151

Kyo compared Takashima's description of "taking a walk to the river to get water," to her mother's account of "going with her sister to fetch water" in the prison camp. ${ }^{152}$ Kyo's maternal grandmother, Aya, also mentioned the importance of books in handing down knowledge of the Internment to children. She thought this knowledge would not be produced unless "we tell them the history of what we went through and reading the books." 153 While she reports that her grandchildren ask her about the Internment, she qualifies what is really possible for them to know by adding. "You have to experience it or otherwise it doesn't click in your mind." 154 
Irene went to her public school library "week after week" to "try to figure out who [she] was." 155 In grades five and six, she took out books on Japan and then realized "Japan...is over here and maybe it's a part of me but not really." ${ }^{156}$ Her comments underline that the "gaps" in knowledge production are also evident in spaces such as the school when books on the Internment are not available. Yet her weekly search speaks enormously of the desire to acquire more knowledge about the space of Canada and her position within it.

Janice stated that her first exposure to a book on the Internment was a book on the U.S. incarcerations. She later became aware of a Canadian book but decided she liked the pictures in the U.S. book and used it for a school project. Her preference for the photographic imagery in the U.S. book also illustrates how people attend to the information in different ways. If visual representation is useful in understanding the spaces of Internment, then perhaps it should also be recognized as a technology different but as valuable as speech/text in the transmission of this understanding to subsequent generations.

The difficulties in re-viewing representation on the Internment, however, are speculated upon by Eiko. She states, "I haven't done a lot of reading. One always wonders psychologically if I'm just in this perpetual state of denial. I don't think so but I do wonder why I haven't gotten more into [reading].... It's hard to figure it all out." 157 As was earlier argued, reading or viewing representations on the Internment exposes survivors and their children to traumatic material. It is for this reason that I would suggest that various supports, both discursive and material, be made available to our community so that these re-sightings of the spaces of Internment do not have to be ones engaged in alone.

What this discussion regarding the use of imagery in production and transmission of knowledge of the Internment underlines is the importance of representation in providing another means of handing down of this knowledge. Rather than situate the representations of the Internment as categorically "outside" of these familial spaces, I would propose that our engagement and even dependence upon this representation in understanding the Internment and its significations clearly bring these various texts into the familial space and cannot be constituted as socially separate from it. Such a 
spatialized analysis acknowledges that representations of the Internment also bring the family space into the public spaces of the nation. Different notions of nation are also conveyed through these texts to survivors and their families. As is apparent from my critiques of this representation, I identify them not as "independent" products of a mind disconnected from community, but they are integrally linked to disciplinary spaces of knowledge production and have discursive and material effects upon those they seek to represent. Sometimes this representation is explicitly produced within the space of the Japanese Canadian community, but always these representations are negotiating the space of the Canadian nation. Hence I feel it important to return to my ongoing interventionist interrogation of the subject who creates these representations and problematize her/his different investments in re-presenting Japanese Canadians, the nation, and her/his self in particular ways. Given the pivotal role of representation in understanding the Internment and in developing a complex and critical awareness of its historical legacy, I would hope that our community would support its generation in its multiple discursive forms by community members and also develop frameworks for evaluating its interpretations in the different spaces within which it circulates. I also would emphasize that representation should attend to the multiple media needs of learners at different ages and with different physical abilities. Developing spatial understandings of the Internment should not depend on the ability to see or hear or be otherwise physically able. The example of photographs is just one means of representing these images.

While all of the women who mentioned the importance of photographs used them as an adjunct to their conversations in familial contexts, it could be the case for other children of families who were incarcerated that they have limited access to this representation or feel they cannot discuss it with family members. It is evident, however, from the use of photographs in the production of knowledge of the Interment that imagining the spaces of incarceration and displacement enhances a daughter's understandings of what that experience meant for familial members. Other forms of representation, including written texts, visual, sound, and other performative media are important in supporting survivors and their children in the handing across of this history. Such representation serves to mediate the spaces of family and the white-dominated spaces we daily inhabit and cannot be construed as separate from these spaces. In the next 
section, I will show how women take up space within white-dominated sites and use their spatial re-memberings to convey the history of Internment to their daughters.

\section{Returning to the Spaces of Incarceration and Expulsion}

Returning to British Columbia and reviewing the home sites from which our communities were forcibly moved and the sites of incarceration is another way in which daughters reported accumulating more knowledge on the Internment. Survivors who visit these spaces with their children pedagogically demonstrate the interconnections between the "physical, mental, social" as they imbue with meanings "empty" or "differently"occupied sites derived from their memories of community. In this way, "places and spaces are actualized and endowed with meaning" 158 by survivors and their families, providing a counter-memory to the sanitization of the landscape and the normalization of space as it is presently configured. "[I]n generating [these] antithetical place-myths," 159 Japanese Canadians contest the "place-myth" that Canada has always ever been a white space and benevolent.

When Midori was in high school, her parents took her to their former homes in British Columbia. She describes her memory in this way: "I remember driving down the street where my mom used to live. Her house was still standing. She was really excited." 160 Years later, she accompanied her parents to the sites where they were incarcerated. When they visited Tashme her mother tried to figure out where the houses had been. She reconfigured the "empty" space through her recollections, "I think it must have been over there. There were some barns there." her family had lived in relation to the barns and was then able to describe the locations of other buildings occupied by particular people. Midori concluded from this trip with her parents, "You go there and stories come out."162

"Going back" to British Columbia is something that Kazuko shared with her sonin-law who is white. "It was very nice of him to take me," she states. ${ }^{163}$ She had not been there since she left Rosebery. The spatialized significances of our history are handed down not only to children but also may include the transmission of this knowledge to non-Japanese Canadian spouses and friends. In this way, survivors affect how nation is 
imagined by non-Japanese Canadians, widening the spatial possibilities for remembering and for re-imagining.

Eiko's aunt, her father's sister, took her to the farm they had owned. She explained that it is now worth "ten million [dollars] U.S." and is a "prime property."164 Mayumi, her partner, and their children accompanied Ann to British Columbia where they saw the memorial dedicated to Japanese Canadian veterans in Stanley Park and read Ann's father's name on the memorial.

Naomi, who lives in Vancouver, has become aware of how the space of Powell Street is now differently configured than it was when her grandmother lived there. "There was an amazing community here... which you could never imagine just going down to Powell Street now. That just disappeared, you know, that's gone."165 This return to British Columbia and carceral sites in other provinces to contextualize (and spatialize) the Internment is envisioned by some women as something they will continue to do with their own children. For example, Sylvia told me she plans to take her child to British Columbia when she is older and explain to her what happened to her family during the Internment.

Survivors employ different strategies in coping with the difficulties that the resighting of the Internment spaces may invoke. including deciding not to return to these sites. When Janice was "really young" she noticed that a member of her extended family could not go "by the barns" whenever they went to the Pacific National Exhibition. Janice's aunt explained to her that her relative couldn't stand to go near the barns "because she was in the barns." 166 As a child, Janice "couldn't quite figure out why" her relative had been "in the barns." 167 As she accumulated more knowledge on her family's spaces of incarceration she understood that for this woman's family "it was so horrible ...because...their father was actually taken right away. He was sent to a work camp."ios She compared this experience to her mother's family where her grandmother and grandfather were both with their children on the sugar beet farm. In this way, Janice demonstrates how elders' memories of community are mobilized to enable children to understand how the Internment was differentially spatialized producing different social consequences.

Other reasons for not returning to the sites of home and incarceration include the prohibitive costs involved in travelling to former sites of incarceration in British 
Columbia, Alberta, Saskatchewan, Manitoba, Ontario, and Quebec, especially with children. Some families would have to travel through more than one province and even to Japan, in order to retrace their processes of incarceration and expulsion.

In addition to the painful memories generated in revisiting the incarceration sites, people are continually reminded of how they are imagined outside of the nation and these reminders are articulated in various ways, including through racist attacks. Kyo described meeting her ex-boyfriend's family for the first time in British Columbia in the early 1990s. After her friend's family picked her up at the airport. his grandmother kept remarking about the "JJaps' bombing..." in the car ride to the family home where she was to meet her friend. ${ }^{169}$ Kyo was left to deal with the racism of the situation herself as no one else in the car challenged the woman's statements. Her comment "I'm sort of angry at myself that I didn't say anything," 170 illustrates how people of colour struggle with feeling responsible for challenging racist assaults while experiencing the shock and trauma of those remarks. She describes her feelings about visiting British Columbia in this way, “as beautiful as the west coast may be...I think a lot of those racist, overt racist attitudes still exist out there." 171

I have been arguing in this chapter that the space of family is a critical site of knowledge production on the Internment. I have also been advocating that this space not be separated from other spaces but in fact could be supported by communal resourcebuilding. Different configurations of the Japanese Canadian communities across the country may support survivors and their children in remembering and I will now turn to some of the ways this support is accomplished.

\section{Section Three \\ Japanese Canadian Community Spaces}

In thinking about the Japanese Canadian community and the Internment, I am filled with many memories and the people who have inspired me to remember and think of remembering in different ways. One memory is of my mother with whom I attended a bazaar at the Toronto Buddhist Church. In the lively setting of the bazaar dining hall, we were seated at a crowded, long table and my mother began to speak to the woman beside her. I had the sense that I was witnessing another reunion between my mother and 
someone she had not seen in a very long time. I later discovered that the woman seated next to her had been her Japanese-language teacher prior to her incarceration in Slocan. She told me she had not seen her since she was a child. As I witnessed this and other reunions between my parents and the people from "before," I have been deeply moved by their significances. It has become important to me to find ways where I too would be challenged to remember and be part of a community of memory. Japanese Canadian community spaces are therefore, for me, a critical space in this commemorative practice.

As the example of my mother illustrates, survivors who renegotiate diverse Japanese Canadian spaces continue to build upon their own knowledge of the Internment through encounters with other survivors, some of whom they have not seen in over fifty years. Although the conversations held in community spaces may not always impart to witnessing children specific information about the incarcerations, just being in the presence of these "reunions" has conveyed to me how extensive were my parents' and grandparents' familial and communal relationships in the 1940s and how these relationships were disrupted and changed through the Internment.

When Louise meets people for the first time in a community space, she asks: ".'Where were you during the Internment?' and things like that.... You find out where they were and whether they knew so and so." 172 For Kazuko these "reunions" are sometimes formalized through dinners organized by people who were incarcerated in particular sites. In this way, survivors create their own spaces for commemoration and being together. The dinners in Toronto are usually held at the Japanese Canadian Cultural Centre. Kazuko has attended one reunion and met people from her home town whom she hadn't seen since before her forced removal to Hastings Park. She told me it was difficult to recognize some of her former neighbours and friends because "most of them have grey hair now and some of them have lost a lot of weight.... But most of them you recognize." 173 She added it is "quite expensive" to attend these dinners. Their cost may therefore be prohibitive to some people who might otherwise choose to attend.

Midori discusses how living in Vancouver is a critical site of leaming about the Internment. This accumulation of knowledge is done through friends whose parents were also incarcerated and through activities such as the Powell Street Festival, an annual celebration held in Vancouver's Oppenheimer Park. ${ }^{174}$ Midori describes how she has 
witnessed people "who come back" to British Columbia at the Festival site and "meet up with their old friends in the park." 175 For Midori, these meetings generate discussions about "the Internment." One of Midori's friends met her parents and they discovered "overlapping people in her family," 176 known to her parents and she is one friend with whom she can discuss this history. Midori emphasizes, however, it is still with her parents that she learns the most about this history.

Midori also described how she witnesses her parents and family members reconstitute the Japanese Canadian community each time they discuss people they knew. At one family gathering they watched a film containing shots of people who were filmed during the Internment, and her parents and other family members verbally sketched out the familial relationships of each person they identified. She described witnessing their memory of community in this way:

I always find interesting about my parents' generation because they know all these Japanese Canadians and their families. It's so different from most of the people I know my age who know some people. But they know who the parents were, all the brothers and sisters. Who they married. The brothers and sisters [of the partners]. You know, it's just like this huge network of families...It's just incredible to listen. I don't know how they remember all the names...I should pay more attention because it'll be lost. ${ }^{177}$

Like Midori, I too have witnessed this phenomenal reconstruction of a network of relationships, rendered in seconds before my eyes. I once remarked to my friend Toshi that I wished that I could remember all the interfamilial connections in the ways in which my Nisei family members and friends demonstrated to me regularly. She responded, "We can remember because we knew each other before, when we were all together."178 Although some of these reconstructions may not even mention the incarcerations, they convey an idea of what was and also an incredible will to remember what was and the people who were interconnected.

In her book, Bittersweet Passage, Maryka Omatsu describes how being in the space of the Japanese Canadian community during the redress struggle actively engaged her in these reconstructed memories of the community. She was often asked if she "was related to such and such a person." 179 On occasion, people would tell 
her an "unknown story about [her] father or [her] family." ${ }^{180}$ The social construction of space is therefore a critical factor in how memories are generated and supported. Children who enter these memoryspaces that our elders have created. as well as spaces we create ourselves, may have opportunities to learn more about the Internment and engage with our own relationships to that history.

The spaces of the Japanese Canadian community are not always ones where everyone feels supported. Naomi described how when she first moved to Vancouver, it was difficult for her to join in some of the community events and she felt excluded by some of them. The Powell Street Festival is one space in which she participates and she comments how the Festival is "coming from certain traditions but it's transforming and creating something entirely new." ${ }^{181}$ However, even though she has lived in Vancouver all of her life, Janice did not attend the Festival until the 1990s. As Kirsten McAllister reminds us, the concept of "community" is useful as long as we recognize that communities are "not necessarily or primarily organized around undermining the relations of subordination in which its members are situated." 182 The spaces of Japanese Canadian community are not therefore unitarily exclusionary or inclusionary. The same community space may have multiple and different meanings for each participant.

As was previously discussed "re-viewing" British Columbia offers generations of the Internment opportunities to spatialize and witness the sites of "home" and some of the incarceration sites. The Japanese Canadian community has formalized commemorative visits to the prison camp sites in the B.C. interior. ${ }^{183}$ As earlier cited, Yuko discussed how going on a tour of these spaces enabled her to speak with her mother about her experiences of incarceration. Irene participated in one tour and stated, "hearing the stories of the people as we passed through the different internment camps, hearing it from the people who experienced it was something." ${ }^{84}$ The tour may also impress upon subsequent generations how spatial separations through incarceration and dispersal shifted the configurations of their families. Irene met some of her father's relatives for the first time and learned about him from people on the tour: "It was great to connect with people who knew his family or lived down the street from his family in [the prison camp] and hear some of their stories about the family or just about living [there] and that whole experience." 185 Her mother, however (see Chapter Six), noted how visiting the prison 
camp sites touches on only part of the spatialization of the Internment and can create an exclusionary notion of the violence if we do not somehow connect all the spaces of incarceration, forced labour, and displacement in our return to specific sites.

My aunt, Kiyoko, and I participated in a tour in 1992. Something she said when we were standing on the site of Tashme, the camp where my paternal grandmother, my uncles, and aunt were incarcerated has stayed with me. She remarked that the children who want to know more about the Internment should participate in the community tours. She explained by adding, "We can't tell you everything ourselves. but when you see where we were, you will find out more about what it was like for us." 186

Other ways of understanding the spatial and social impact of the Internment have become formalized through individual and community effort. While these interventions are too numerous to mention here, they include walking tours of the Powell Street area conducted by Audrey Kobayashi, whose re-constitution of the space - where businesses and community spaces were situated in 1941 - gives a clear and stark example of what was spatially dismantled and socially lost in the 1942 expulsion. ${ }^{187}$

Efforts to build an understanding of the Internment and of the importance of communal ties are not just a reflection of present-day efforts. Haru reminded me of this in her interview and told me her husband decided he wanted one of his daughters to go to Washington to attend a "Japanese American Conference" in the 1960s Their daughter, who was a teenager replied, "What do I want to go there for?" She, however, attended the conference and Haru notes, "She was so impressed.... She just raved."

\section{Conclusion}

In this chapter, I have used the concept of 'handing down' to describe the processes through which family members convey knowledge of the Internment to their daughters. I have looked at some of the ways this knowledge is transmitted through the space of family, representational spaces, and Japanese Canadian communities. It must be emphasized that these spaces are not discrete and separate but are interconnected and overlapping.

While some have constituted survivors as categorically "silent" about their incarcerations, I suggest that we use a spatial analysis to understand how people struggle 
both to accumulate knowledge on the Internment and to communicate this knowledge to others. In constituting the space of the dyadic parent-child relationship as "silent," we rely upon a hegemonic notion of family. Perhaps, we could rethink the spaces of this hegemony and witness how women understand the violence of the Internment through their imagined reconstitution of communal and familial relationships, both in acknowledging those who in different ways testify to its effects and through seeing those absented from their family spaces through the processes of displacement.

Finally, we have witnessed how people use the spaces of family and community differently and impose various meanings upon these spaces. In this way, people with an intimate and enduring knowledge of national violence create different spaces of imagining the nation. Through these courageous practices of remembering and handing down memory, cracks appear in the normalization of Canada as a coherent, benevolent space and the space of nation is shown to be "inherently unstable." ${ }^{189}$ In the next chapter, I will examine what knowledge is produced through these spatial arrangements and how women contest the forgetting of the Internment and struggle with other hegemonic practices in the white spaces of nation.

\section{Endnotes: Chapter Eight}

1. Mayumi [pseud.], interview with author, tape recording transcript, 1 November 1995 , p.27.

2. Muriel Kitagawa, This Is My Own, p.229.

3. Interview with Mayumi, p.27.

4. Yael Danieli, "Treating Survivors and Children of Survivors of the Nazi Holocaust," in Post-Traumatic Therapy and Victims of Violence, pp.278-294, edited by Frank M. Ochberg. (New York: Brunner/Mazel, 1988), p.280.

5. See, for example, Dan Bar-On who states, "It was precisely this gap - between what was transmitted verbally and what was transmitted nonverbally - that most strongly influenced the next generation" in Fear and Hope: Three Generations of the Holocaust (Cambridge and London: Harvard University Press, 1995), p.355.

6. Martin S. Bergman and Milton E. Jucovy, preface to Generations of the Holocaust (New York: Columbia University Press, 1990), pp. 19-20.

7. Danieli, "Treating Survivors," p.279. 
8. Ibid., p.289, emphasis in the original.

9. Donna Nagata, Legacy of Injustice, xiv.

10. Ibid., p.51.

11. Ibid., p.17.

12. Ibid., ix.

13. Ibid., p. 101 .

14. Ibid., p.113.

15. Ibid., p.102.

16. Ibid., p.77.

17. bid., p.76.

18. Makabe, Tomoko, Shashinkon no Tsumatachi (Tokyo: Mirai-sha, 1983); and Makabe, Picture Brides.

19. Makabe, The Canadian Sansei, p.3.

20. Ibid., $x$.

21. Ibid.

22. Ibid., p.80.

23. Ibid., p.75.

24. Ibid., p.78.

25. Ibid., p.82.

26. See the bibliography to this thesis for references to works by these cultural producers and also Aiko Suzuki's important directory of artists, Japanese Canadians in the Arts: A Directory of Professionals (Toronto: SAC/rist, 1994). In addition, see Aiko Suzuki, ed., About Japanese Canadians, Resource Listings III, revised by David Fujino (Toronto:

Toronto Nikkei Archive and Resource Centre, 1996).

27. Makabe, The Canadian Sansei, p.82.

28. Foucault, Power/Knowledge, p.83.

29. Ibid. 
30. Soja, Postmodern Geographies, p.120.

31. Shields, Places on the Margin, p.51.

32. Ibid., note 11, p.69.

33. Yeğenoğlu, Colonial Fantasies, p.21.

34. Kang, "Compositional Subjects," p.36.

35. Ibid., p.94.

36. Yeğenoğlu, Colonial Fantasies, p.49, emphasis in the original.

37. Ibid., p.46.

38. Michel Foucault, Power/Knowledge, p.83.

39. For writings analyzing violence against women and children in the family, see for example, bell hooks, "Feminism: A Transformational Politic," in Talking Back: Thinking Feminist, Thinking Black (Boston: South End Press, 1989), pp. 19-27; Joanna Kadi, Thinking Class (Boston: South End Press, 1996); Fauzia Rafiq, ed., Towards Equal Access (Toronto: Education Wife Assault, 1991).

40. Philomena Essed uses the term, "everyday racism" to mean "various types and expressions of racism experienced by ethnic groups in everyday contact with members of the more powerful (white) group. Everyday racism is, thus, racism from the point of view of people of color, defined by those who experience it." Essed, Everyday Racism (Claremont, CA: Hunter House, 1990), p.31. I use her term and apply it to various forms of social domination, including racism, and also point out how while Japanese Canadian survivors have undergone the racism of the Internment, they and their racialized family members continue to undergo racial subordination in a white-dominated country.

41. Shields, Places on the Margins, p.53.

42. Interview with Haru, pp.53-54.

43. Interview with May, p.41.

44. Interview with Mayumi, pp.21-22.

45. Midori [pseud.], interview by author, tape recording transcript, 24 August 1995, p. 18 .

46. Yuko [pseud.], interview by author, tape recording transcript, 6 November 1995, p. 18 .

47. Ibid., p.14.

48. ㅁid. 
49. ㅁid.

50. Naomi [pseud.], interview by author, tape recording transcript, 31 December 1994, p. 17.

51. Ibid., p.19.

52. Eiko [pseud.], interview by author, tape recording transcript, 30 November 1995, p.5.

53. Ibid., p.32.

54. Kyo [pseud.], interview by author, tape recording transcript, 30 June 1995, p. 14.

55. Ibid.

56. Ibid., p.61.

57. Ibid.

58. Sylvia [pseud.], interview by author, tape recording transcript, 29 September 1996. p.14.

59. Ibid.

60. Ibid.

61. Ibid.

62. Ibid., p.43.

63. Janice [pseud.], interview by author, tape recording transcript, 23 August 1995, p.18.

64. Ibid.

65. Ibid.

66. Joanne [pseud.], interview by author, tape recording transcript, 31 October 1995 , p.36.

67. Ibid.

68. Ibid.

69. Ibid., p.46.

70. Ibid.

71. Irene [pseud.], interview by author, tape recording transcript, 16 June 1995, p. 14. 
72. Ibid.

73. Ibid., pp.15-16.

74. Ibid., p.35.

75. Ibid.

76. Ibid.

77. Interview with Margaret, p.77.

78. Interview with Naomi, p.22.

79. Ibid., pp.22-23.

80. Ibid., p.23.

81. Interview with Yoshiko, pp.53-54.

82. Ibid., p.54.

83. Ibid., p.56.

84. Ibid., p.56.

85. Interview with Aya, p.55.

86. Mayumi quoted in interview with Ann, p.31.

87. Interview with Mayumi, p.27.

88. Interview with Ann, p.13.

89. Interview with Kyo, p.48.

90. Interview with Irene, p.12.

91. Interview with Sylvia, p.37.

92. Ibid., p.38.

93. Ibid., p.37.

94. Ibid.

95. Ibid., pp.39-40.

96. Interview with Kyo, p.10. 
97. Canada, Bureau of Statistics, Ninth Census of Canada, 1951, vol.10 (Ottawa: 1956), p.194.

98. Ibid.

99. Ibid.

100. Interview with Mayumi, p.20.

101. Ibid.

102. Ibid.

103. Interview with Kyo, p.20.

104. Ibid.

105. Ibid., pp.18-19.

106. Ibid., p.21.

107. Ibid.

108. Interview with Joanne, p.35.

109. Interview with Janice, p.40.

110. Interview with Irene, p. 15.

111. Interview with Yoshiko, p.50.

112. Ibid., p.51.

113. Interview with Midori, p.17.

114. Interview with S., p.56.

115. Interview with Esther, p.85.

116. Interview with Joanne, p.44.

117. Interview with Ann, p.93.

118. Ibid., p.95.

119. Roger I. Simon and Wendy Armitage-Simon, "Teaching Risky Stories:

Remembering Mass Destruction Through Children's Literature," English Quarterly 28, 1 (Fall 1995), p.27. 
120. Ibid., p.30.

121. Ibid.

122. Ibid., p.31.

123. Interview with Yuko, p.19.

124. Ibid., pp.181-19.

125. Interview with Naomi, pp.17-18.

126. Lisa McCann and Laurie Anne Pearlman quote R. Janoff-Bulman in describing how "victimizing life events" challenge "the belief in a meaningful, orderly world," in

"Vicarious Traumatization: A Framework for Understanding the Psychological Effects of Working with Victims," Journal of Traumatic Stress, 3, I (1990): 137. I would like to thank Claudia Lopez for giving me this reference.

127. McCann and Pearlman define "secondary victimization" as when "persons close to the victim, such as family members, may suffer signs and symptoms of traumatization similar to those of the victim," in "Vicarious Traumatization," p.135.

128. McCann and Pearlman define "vicarious traumatization" as the "experience [of] profound psychological effects, effects that can be disruptive and painful for the helper and can persist for months or years after work with traumatized persons," in "Vicarious Traumatization," p.133.

129. Makabe, The Canadian Sansei, p.5.

130. Interview with Joanne, p.14.

131. Ibid., p. 15.

132. Interview with with Sylvia, p.34.

133. Ibid., p.35.

134. Interview with Naomi, p.21.

135. Interview with Joanne, p.41.

136. Ibid., p.42.

137. Ibid., p.43.

138. Sturken, Tangled Memories, p.9.

139. Ibid., p. 10. 
140. Interview with Janice, p.19.

141. Ibid., p.20.

142. Ibid.

143. Interview with Kyo, p.21.

144. Sturken, Tangled Memories, p. 10.

145. Interview with Yoshiko, p.50.

146. Adachi, The Enemy That Never Was, p.209.

147. Interview with Naomi, p.17.

148. Ibid., p.20.

149. Ibid.

150. Takashima, A Child in Prison Camp.

151. Interview with Joanne, p.60, emphasis in the original.

152. Interview with Kyo, p.60.

153. Interview with Aya, p.61.

154. Ibid.

155. Interview with Irene, p.25.

156. Ibid.

157. Interview with Eiko, pp.59-60.

158. Shields, Places on the Margin, p.60.

159. Ibid., p.61. Rob Shields' definition of a "place-myth" (p.60) is a set of "placeimages." The latter are "various discrete meanings associated with real places or regions regardless of their character in reality."

160. Interview with Midori, p.49.

161. Ibid., p.46.

162. Ibid., p.47.

163. Interview with Kazuko, p.62. 
164. Interview with Eiko, p.32.

165. Interview with Naomi, pp.26-27.

166. Interview with Janice, p.44.

167. Ibid.

168. Ibid.

169. Interview with Kyo, p.32.

170. Ibid., p.33.

171. bid., p.33.

172. Interview with Louise, pp.89-90.

173. Interview with Kazuko, p.38.

174. 1999 marks the twenty-third Powell Street Festival. While there has been some pressure to move the Festival to another site, the current Powell Street Festival Society remains committed to its historic location in Oppenheimer Park (400 Block Powell Street). As Susan Nishi explains, this site is the "historical tie to Japantown, the area where many of the first Japanese immigrants lived. The Festival is also linked to the people and the organizations in the area that have supported our celebration for the past 23 years." Nishi, "The Neighbourhood and Local Heroes," Powell Street Festival 5, 1 (February 1999), n.p. See also Tamio Wakayama's photographic representation and textual description of the Powell Street Festival in Wakayama, Kikvo: Coming Home to Powell Street, oral histories edited by Linda Uyehara Hoffman (Madeira Park, BC: Harbour Publishing, 1992).

175. Interview with Midori, pp.76-77.

176. Ibid., p.27.

177. Interview with Midori, pp.25-26.

178. I would like to thank Toshi Oikawa for sharing her knowledge with me.

179. Omatsu, Bittersweet Passage, p.35.

180. Ibid.

181. Interview with Naomi, p.14.

182. Kirsten Emiko McAllister, "Cultural Production and Alternative Political Practices: Dialogic Cultural Forms and the Public Sphere in the Japanese Canadian Community." (master's thesis, Simon Fraser University, 1993), p.44. 
183. For an analysis of one filmic representation of a bus tour to the Lemon Creek incarceration site, With Our Own Eyes: A Trip to Lemon Creek, by director Ruby Truly, see McAllister, "Cultural Production."

184. Interview with Irene, p.32.

185. Ibid., pp.32-33.

186. I am indebted to my aunt Kiyoko Oikawa for sharing her knowledge with me.

187. Kobayashi, Memories of Our Past.

188. Interview with Haru, p.112.

189. Shields, Places on the Margin, p.65. 


\section{Chapter Nine \\ "Crushing The White Wall WITH OUR Names": \\ RE-MEMBERING THE INTERNMENT IN WHITE SPACES}

\section{Introduction}

In the last chapter, I discussed some of the ways in which daughters are handed down subjugated knowledges of the Internment through the spaces of the family, representation, and the Japanese Canadian community. In this chapter, I will examine how women resist hegemonic knowledge production in white spaces and how they situate themselves as subjects struggling with these hegemonies. I will examine what knowledge is produced through these "mnemonic encounters"2 between these witnesses to the Internment and non-Japanese Canadians. This will be done by first looking at the space of school and how women use this space to produce knowledge of the Internment. The second section will illustrate how women contest the forgetting of the Internment produced in other white spaces.

\section{Section One \\ Contesting the Forgetting of the Internment in the White Space of School}

In this section, we will see how women confront the forgetting of the Internment in the space of school. The school space will be shown to be a white-dominated space and a space of violence, where racist attacks occur regularly upon students of colour. That women take note of the "silence" of the people existing within these spaces on the history of Internment and on other marginalized histories is a part of the insurgent knowledge produced by these women. The ways in which women struggle to produce knowledge that fundamentally challenges the ways in which we imagine the nation, in a space that contributes to domination through forgetting of this history, are evidence of resistance to domination.

Donna Nagata mentions in her study that the lack of curricular attention to the "injustice of interment" in schools contributed to the paucity of information provided to the Sansei. ${ }^{3}$ School was described by some mothers and daughters I interviewed as a site of racism. After being moved to Winnipeg, Margaret attended high school in the late 
1940s. She reported, "There were times when I really hated to go to school," due to fights with other children because "we were Japanese." I I asked Louise, who went to public school in northern Ontario in the 1950s if she was ever taught about the Internment in school and she replied, "No. Never. Never. No."s

As was stated in Chapter Five, government records on the Internment were restricted from public use until the 1970s. Lack of accessibility to these records contributed to the forgetting of the Internment, as the extent of the violence and the documentary evidence of that violence lay buried in government vaults. In addition, all survivors had to attend to immediate material needs and thus researching and representing the social construction of their own incarcerations would have entailed resources and time that few may have afforded. As we saw in the last chapter. people continued to produce knowledge of the Internment in various forms in the family space as well as other spaces. As we shall see in this section, despite the violence encountered in the white space of school, this space is used by survivors and their children to contest the ways in which the Internment is forgotten in the educational system.

Two survivors used the university space to find out more about the government's policies during the Internment. Esther told me she had undertaken research at the university and had discovered, "Japanese Canadians only got the vote in 1949." "I never knew that.... It's not very long ago, is it?"6 Yoshiko also did research on the Internment for a university course. Both women testify to the ways in which survivors continue to accumulate knowledge on the social construction of their incarcerations, years beyond the events. Haru, however, reminds us that many people from her generation were unable to continue their educations after they were displaced from British Columbia. "My husband and I didn't even go to university," she states. "It was a big accomplishment when our children wanted to go to."7 Although Japanese Canadians as a group have been noted as being "highly educated" or acquiring some university education, in 1986 only three per cent over 75 years of age had some university education. ${ }^{8}$ The university as a space to develop understanding of the Internment has not, therefore, been accessible to all Japanese Canadians, and as we shall see it is not a site that necessarily supports a critical understanding of the Internment. 
Eight of the daughters interviewed reported completing projects on the Internment during their years of schooling. Three of these women undertook this work at a university. All of them initiated this research on their own as special topics not part of the regular curriculum. Only two women reported being taught about the Internment in public school.

The daughters interviewed went to elementary and high schools in the 1950s to 1990s. Some of them attended universities in the 1990s. Five of the women used the space of public school to produce projects on the Internment. Most of the women had white teachers during their public school and post-secondary education. ${ }^{9}$ Most of the daughters reported the school as a space where they experienced racism.

Mayumi, who went to public school in Toronto in the late 1950s and 1960s, reported she only had white teachers. There were no other Japanese Canadian children in her elementary school. There was only one other Japanese Canadian student in her senior public school. "The only other Japanese people I knew were my relatives," she adds. ${ }^{10}$ Mayumi was never taught about the Internment, although she speculated that "it is now [taught] in school.... It wasn't then, not at all."1!

Before I interviewed Yuko, her mother had described to me the social context of her daughter's public school years of education. In this brief testimony, she socially contextualized her daughter's complex and relational situatedness to other students through race, gender, class, and age. Her description conveys how these social relations are contrapuntally spatialized and how the classroom is a space through which different social spaces are mobilized. Her testimony also conveys her awareness of how her daughter was constructed as "different." Based on her profound knowledge of violence and its potentiality, Haru's exquisite consciousness illustrates how survivors must negotiate their own knowledge in relation to the care of their children.

Haru described to me how she knew the space of schooling for her daughter was a white space: "My daughter was the only Japanese in that school."12 She also analyzes how their family's working-class economic position situated Yuko relationally to her middleclass classmates who were "children of young executives, vets, and middle class families" who could afford to participate in different social activities. ${ }^{13}$ She repeated that her daughter's classmates were children of "young vets that came back from the war, who 
were involved in war." 14 This remark signalled to me an awareness that her daughter could be immediately targeted by the "disloyalty" discourse as the badge of "loyalty" would be the much-lauded mark of the white veteran's children, serving to deny Yuko's family's history of incarceration and their own years of service to Canada during and after the war. There is a sense of danger evoked through her comments and a concern for her daughter, as the highly masculinized sign of the white war hero is emblematically displayed through the bodies of their children in the space of the school that she must daily attend. Haru states, "I remember she was accepted as who she was as another student, but socially I don't think she was fully accepted." 15

Yuko, who is two years younger than Mayumi, reported there were no other Japanese Canadian families in their neighbourhood and it was not until high school that another Japanese Canadian family moved into the community. She had found out recently that one of her classmates from high school is mixed-race Aboriginal, but in this educational setting he had not openly identified as Aboriginal. There were no other people of colour in her years of public school and all of her teachers were white.

Yuko recalled one memory where a much younger child called her racist names and she felt really hurt by this. She doesn't remember experiencing racism when she was in public school but then remarked that she may have rationalized how she was treated by explaining to herself it was due to her small size. As she states, "I always used to be labelled a "China doll' because I was so tiny." 16 Racialized constructions of children are always also about racialized en-gendering. In this case the "doll," being the heightened sign of femininity, is racialized by the determination of the originary as China (standing in for all of Asia). The white Orientalist gaze mobilizes the punning notion of the feminine figurine of China and distinguishes itself as objectifier of the woman who will remember and name the naming.

Yuko also noted that a couple of teachers in high school had mentioned that she was Japanese and asked what that was like for her. It was at high school that she began to discuss her experiences of racism with her friends. She remembers their reply: “[We] don't see you as being Japanese. We just treat you the same and don't see you as being any different."17 
Yuko reports never being taught about the Internment at school. She states,

We were never taught about the internment. We were never taught about the Canadian Indians.... We were taught about European history, American history and never taught about any ethnic group. It was really from a Eurocentric perspective. ${ }^{18}$

Within the context of discussing racism, Yuko also described how she had applied for a bursary after graduation from high school and had to attend an interview. Most applicants' interviews lasted an hour and her's was fifteen minutes. She remembers the questions revolved around her "being Japanese." "I thought that was very odd," she added. She further noted:

Now in hindsight I can see that it was probably racism and discrimination and they had just gone through the motions to be polite. They had no intention of awarding me any kind of bursary. ${ }^{19}$

Sylvia, who is a few years younger than Yuko, also went to school in Toronto. She and her cousins were the only Japanese Canadians at their public school. In elementary school, there were no other Asian Canadian students and when she reached grade six or seven, there was one Black student in her class. All the other students were white. At high school there were one or two other Japanese Canadian students. Sylvia has "very, very, strong, vivid memories" of racism at school. ${ }^{20}$ "That was very hurtful and I dealt with it by myself," she states. ${ }^{21}$ Sylvia remembers having to deal with racism and class oppression because her family lived in a middle-class neighbourhood and they were working-class people. She was never taught about the Internment at school, "not in high school, not in university either."22

Irene, who attended school in Toronto in the 1960s and 1970s reported there were only two other Japanese Canadian families in her area who had children attending school. She reports experiencing racism, "mostly from people who didn't know me very well, acquaintances...just knew me to see me across the school yard." ${ }^{23}$ The racism was uttered in the form of "rhymes" and other kinds of speech. She explained that her friends were supportive of her and she hadn't felt that she was "different" until people said these things to her. In this context, she also described how her primary school teachers were "patronizing" in their requests that she perform odori for them, going class-to-class, dressed in a kimono, for show-and-tell. She explains her realization that teachers had 
been "treating me as an object or curiosity," a "cultural sort of exhibit" came years later when she was an adult. ${ }^{24}$

When I asked her if she was ever taught about the Internment in public school or college, she replied, "'No. No. Never. No, it was never mentioned." 25 She adds, "I don't know how much Canadian history I ever learned to begin with. I don't think I learned anything about World War II anyways. So, the opportunity wasn't there to learn about the internment." 26 Within this context of discussing curriculum, she emphasizes her own role as pedagogue, "I must have mentioned it to people as a kid. I'm sure a lot of people were surprised."27 This role she continues to this day, "talking to adults."28

Midori, who went to school in a prairie province in the 1970s and 1980s, thinks she may have studied the Internment in school. She remembers doing a project on the incarcerations in junior high. This, however, was not her initial exposure to this knowledge; she recalls, "knowing about it, some of it, a bit before that." 29 She chose to work on this project because she was "interested and knew a little bit about it and wanted, by doing a project, to find out more of the details." ${ }^{30}$ She states "It could have been about anything really. So it wasn't taken as something that you shouldn't talk about. It was just like :inybody's project." 31

Joanne went to public school in British Columbia in the 1960s and 1970s. She recalls having one teacher who was not white in high school. She described the racism experienced by her and the few other classmates of colour. Her mother switched her to a more middle-class school and the white boys at that school also called her racist names. Although other women interviewed report being the target of racist attacks by both male and female children and adults, Joanne emphasizes how the perpetrators in her school were male: "It was always the boys in class who would say horrible things...or would call me names." 32

Joanne was also never taught about the Internment. In high school there was a section on World War II in social studies. She remembers, "I was given another project to work independently on, which is interesting." 33 In this instance, we see how the student who is racialized challenges curricular practices that collide with her/his subject position. This is an embodied contestation, where the mnemonic encounter between the Japanese Canadian student and the white teacher results in her "removal" from the lesson. That the 
teacher is also negotiating the mnemonic differences suggested by the study of World War II for different students is apparent here. Yet the solution offered, to exclude one student and continue with the lesson, assumes that the other children are unifiedly included and addressed in its undertaking. As Lisa Lowe points out, the "history" lesson on World War II instantiates a nationalist narrative that "recognizes, recruits. and incorporates males subjects, while 'feminizing' and silencing the students who do not conform to that notion of patriotic subjectivity. "34 It is also a pedagogical moment that reenfigures the "Asian as 'enemy'." In this case, the teacher's conscious removal of Joanne from the lesson signifies the choice to continue with the narrativization of dominance. The strategy of removing one child from the textual encounter with the set curriculum does not change the relations of domination embedded therein and also continues to mark the "difference" of the excluded child. The unifying address witnessed in this pedagogical moment - how we, as Canadians, view World War II - I would argue is about imagining a hegemonic white masculinity in relation to nation, while the view of "others" is relegated to the margins and reinscribes their "difference."

Janice went to school in Vancouver in the 1970s and 1980s. She lived in a "very all-white neighbourhood." 36 In her elementary school, there was one "Black girl," one "Indian boy" and "maybe two Asian kids." 37 There was only one time where she was in the same class as another Asian person; he was Chinese Canadian. All of her teachers were white with the exception of one teacher in high school.

Janice described how at an early age she was aware she was living in an "antiAsian" province. She deduced this from the racial slurs she heard directed at Chinese Canadians, which she remembers as pre-dating her memories of racist language directed at her and other Japanese Canadians. She shares this profound insight into how she came to understand how racism directed at other people was intrinsically connected to the Internment: "I knew that somehow the racism directed at other racial groups had something to do with what happened to us." 38

She remembers one white boy calling her by a racist word when she was in grade four. In her vivid memory of that incident, she is able to describe the appearance of the student and even recalls his name. She situates herself, however, in relation to her friends of colour by stating that "a lot of time people can't tell I' $m$ Asian" and described how in 
high school she witnessed the racism targeted at her friends who "were always" experiencing these attacks. ${ }^{39}$

In the early 1980s, Janice "chose to do" a multi-media project on the Internment in grade twelve for her social studies class. She describes how "It was a free-for-all kind of choose whatever topic you want to do." 40 Her aunt was pivotal in her researching the project and "copied all these photos out of books." "It was easy for me because I was really familiar with the material," she concluded."

Here Janice emphasizes that she was already familiar with some of the history of Internment and worked with her aunt to present this knowledge to her classmates and teacher. Years later, when Janice met former classmates, some of them remarked, "[We] remember that presentation you did." $"$ Janice describes this reaction as reflecting what before her presentation had been a "huge gap in their learning" and she noted "That's the first time they'd ever known anything about it...there was nothing in any history [text] book about internment." ${ }^{43}$ As do many other Japanese Canadians who struggle with the forgetting of the Internment in white spaces, Janice does the pedagogical work not undertaken by white people themselves. Her lesson occurred in the school space of Vancouver in the 1980s. Whose silence is reflected in this space of school? Certainly not Janice's nor her family's who had instilled her with a "familiarity" with their history and supported her in its representation. Who were the other students in this classroom and how was this "gap" in their learning about the space of Vancouver (and the space "inherited" by some of them from their parents) produced? The strength it takes to generate this insurgent knowledge is underscored by Janice's marking it as "the first time I'd ever really had to publicly talk about it."

Naomi went to school in northern British Columbia in the 1970s. Her family members were the only Asians in the town where her mother resided. Most of her schoolmates were Aboriginal, although there were a few white children. She described growing up in a context where there was "a lot of racism" directed at Aboriginal children. She constructs her own experience of racism spatially as she describes how she would visit her father, who is white and who lived in the white area, and was verbally assaulted with racist language by people who thought she was Aboriginal. Her mother, however, lived in the space identified as Aboriginal. 
She answered my question about how she came to know herself as "Japanese Canadian" by telling me a schoolmate had called her an anti-Japanese name in the school yard when she was in grade three. "I didn't understand what [the word] meant really. I knew it was bad, but that's the extent of it."4s

Naomi recounted how she was "crossing those boundaries all the time" between the white space and the Aboriginal space and asking herself, "Am I Indian? Thinking, perhaps, that's perhaps what I was....And then going to school and being called [racist names] by the Native kids. ${ }^{46}$ Naomi's complex negotiation illustrates how her construction by others was contingent upon the space she inhabited or entered and the systems of domination constructing these spaces. Lest we reduce Naomi's testimony and struggle within these spaces, however, to the liberal dictum, "Well, everyone is racist," let us hear how she came to understand her own experiences of subordination:

It gets quite complex when you look at who this person is in the community [who was calling me racist names]. He was a very sort of white-looking Native person. He was from a very wealthy family and you know who these slurs came from... it fits in with how racism works. The poorer darker-skinned Native kids got it too, you know, they got the brunt of that kind of stuff as well. And they weren't the ones who would call me [racist names]. ${ }^{47}$

Naomi presents her understanding of how the white bourgeois space was still producing the relations of domination in the Aboriginal space as whiteness, masculinity. and class domination or the desire to enact these dominant subject positions create a hierarchy within a racialized space, mobilized through attacks on other racialized, classed, and gendered people. Naomi's mother, however, also had a certain class privilege as she worked in the Aboriginal community, but as the only Asian woman. All of these interlocking systems of domination went into Naomi's understanding of herself as "on the boundaries" of white and racialized spaces. ${ }^{48}$

Naomi remembers being able to talk to her mother about these incidents and although she doesn't recall the content of these conversations, she knows her mother reinforced her and told her that any racist language being used against her was wrong. She, however, doesn't remember specifically discussing the anti-Japanese language or what those words meant. 
Naomi's family moved to Vancouver and she attended a school where there were many Asian children. There were no Japanese Canadians in her class. Within this racialized space, however, Naomi was seen as Aboriginal and she remarked how the other children "didn't like me because I was Native." 49 The spatialization of her racializing was reinforced by the teacher as Naomi was told to sit with the lone Aboriginal student in the class who was ostracized by everyone. She recalls one day she was asked "What are you?" by the students. She replied she was Japanese and white, and the response was "We can be your friend now, you're not Native." 50 "It was really disturbing to me," she concludes. She said she learned how "the Native kids... in this city were always ostracized."51

Within these educational settings, Naomi was never taught about the Internment. In high school, students were allowed to "choose topics," and she chose to work on something about Japan She recalls writing something about the Internment for her project but "nothing in-depth." 52 Even within a space where there were many students of colour, the school space still remained a white space of forgetting and where nation was actively remembered as white.

As the producer of this thesis text, I was wary of including Naomi's description of the complexities in how she was constructed racially in different spaces by white, Aboriginal, and Asian students. I have risked sharing what Naomi has taught me through her testimony, even though I heed Sherene Razack's warning that "We still cannot speak out loud about the complexities of racial identities without risking that the oppressive contours of racism will be denied." 53 I fear, however, that the opportune and "safe" historical moment for this discussion may never arrive and I hope that there are some with whom this conversation can occur and it is to them that I address the content of this hope.

Naomi's testimony points out the difficult though necessary discussions we must have within and between communities of colour regarding the social domination we enact and experience as we "cross the boundaries" of our spatialized existences. This includes the exclusionary practices mobilized through different Japanese Canadian community spaces. As women of colour, our energies are so often depleted by addressing the multiple forms of subordination - racism, sexism, classism, homophobia, ableism - we 
variously experience in different spaces. Yet we also have the ability to subordinate others through our attainment of or our desire to attain dominance in these different social locations.

Naomi's incisive analysis lays bare the social relations: it is interlocking systems of domination constructing these relations through the various spaces of our existence. The same racialized person can move through different spaces and find her/himself positioned on different steps of the hierarchy; but let us be clear that the pinnacle of whiteness inscribed through white supremacy will never be attained by the racialized body in a nation that is always imagined as white. If we do not see how the white nation and white spaces are materially producing the pathologized and racialized spaces, then we may reduce what happens in these spaces to a liberal analysis of autonomy. If we do not see how we are relationally constructed through these social hierarchies, we cannot hope to undermine these constructions.

Kyo, who went to school in Toronto in the mid-1970s to 1990s, was the only person other than Midori to report being taught about the Internment in public school. There were no Japanese Canadians in her elementary school and she remembers there being one Korean Canadian family attending that school. She reports experiencing racism as well as verbal abuse from other school children as she walked down the street. She had only one teacher of colour and that was in high school. Kyo describes the lesson on the Internment as lasting "ten minutes" in grade nine Canadian history. ${ }^{54}$ She recalls being shown a film and the teacher "talked briefly about it in terms of World War II, in that context." 55 She states, "at that point, I didn't really know that much about it either, just that my grandfather's boat had been taken away, had been confiscated." 56 She remembers telling the teacher during the film, "That happened to my grandfather." 57 The teacher replied, "Oh, that's interesting." But Kyo then described how "After the film, she discussed it and said, 'That happened to Kyo's grandfather." 58 When I asked her how she felt after seeing the film, Kyo replied:

I don't even remember what the film was. I probably [felt] angry but also maybe a little embarrassed, too. You know, being in this whole class of white people. ${ }^{59}$ 
Kyo's example reminds us of how the "risky stories" of racialized students can become the empirical data used by a teacher or other students. Disclosing these stories can be even more risky given the teacher's power and the power of whiteness in the classroom. The very bodies of these students become the ground on which a national collective forgetting and remembering gets pedagogically displayed. They become the lesson. The lone student becomes constructed as the only witness. The silence of the white witnesses to the Internment and their collective national forgetting is elided through the discursive construction of the white students as "ignorant."

Eiko, who went to school in Toronto in the 1950s and 1960s, replied, "No. Not in high school, not anything" when I asked her if she was ever taught about the Internment. ${ }^{60}$ She remembered, however, "learning about World War II though. And not quite knowing how to feel." 61 She compared the feeling to that which she had recently experienced when a fellow classmate was criticizing a well-known Japanese Canadian man and kept looking at Eiko during his comments. Her response to how these pedagogical moments call attention to her body in the classroom is: "Why are you uncomfortable with this history?... Why are you uncomfortable?"6?

The desire to produce more understanding of the social meanings of the Internment and represent them to oneself also continues in post-secondary institutions. Four of the women produced projects on the Internment within the space of the university.

The only woman who reported the Internment being mentioned in a university course lecture was Kyo. This occurred in an Ontario university in a Women's Studies course when they studied the novel, Obasan. When I asked her what it was like to study the novel within that context, she replied,

For the first time you're reading about experiences that you can really identify with.... I'd read articles for that class that I could identify with in [terms of] gender. It was really interesting to be able to identify with a woman on a racial level, too, in terms of experiences. Not just racial, but cultural level. ${ }^{63}$

For Kyo, the reading of Obasan gave her a space to engage issues of gender and race in a Women's Studies course, and particularly the position of Japanese Canadian women within the Canadian nation. Yet, as was seen in Chapter Two, "critical" 
interpretations of this novel do not necessarily undermine stereotypical representations of Japanese Canadian women. While much literary criticism on Obasan has been generated by non-Japanese Canadians, it would be important to further investigate how survivors and their children respond to this text.

Janice reported that at her university, in British Columbia, all of her professors were white except for one woman. Her first-year Canadian history textbook included a paragraph about the Internment in the section discussing World War П. "A whole paragraph!" she emphasizes. ${ }^{64}$ Joanne also did a paper on the Internment for a geography course taken in British Columbia.

Sylvia described how she did research on the Internment when she was working on a bachelor's degree. This was for a "gender course" in sociology and the students chose to "do a research paper on anything [they] wanted." 65 The Internment "wasn't part of the formal course curriculum," she emphasized. ${ }^{66}$

Yuko also did a paper on the Internment in a sociology course at an Ontario university. She describes herself as "naive" in the selection of the topic. which was "the psychological and sociological implications of the internment during the Second World War." 67 She reported how she read through all the newspapers on microfilm to "dig" for information because "there wasn't a whole lot of information around about the internment." 68 She added that her father was "reluctant" to give her information for her project. She emphasized that the Internment "wasn't part of the curriculum" and the paper could have been on "any topic." She was pleased, however, that she received a "good grade on the paper." 69

Naomi completed a project on the Internment while she attended a British Columbia university. "It wasn't part of the curriculum. No one else had to do it.... That was the one and only time that I've actually done research and pursued that in any depth," she states. ${ }^{70}$ She used "well-known" books as her secondary sources; in addition, her literature search included empirical research produced by Japanese Canadians, which she retrieved through a Japanese Canadian community library. Naomi describes the response of her white professor, a "British woman," in this way:

The professor criticiz[ed] me for being too political and for coming to the conclusion that I did. [She commented] that I wasn't being fair to the 
Canadian government. I read it now and I just get really angry.... This is racism. This is terrible.... The one time that I pursued this and came to a clear conclusion that what happened [to Japanese Canadians] was to appease the fears of the white racists in B.C., the professor flipped out. She really did not like to hear that in a paper; that was not acceptable. That was in university.... That was only in $1990 !^{71}$

Naomi concludes, "It's pretty frightening that this happens and a lot of people don't realize this is what it is like.... There's a lot of resistance to this stuff. Just talking to you I'm realizing how non-existent it has been. And...just the silence around it." 72 In this commentary, Naomi identifies what she confronts in the space of school as a "resistance" to articulating her subjugated knowledge of the Internment and the knowledge produced by community members. She also notes how her interventions intrude upon the silence of the schooling space. Naomi's recent experience also points out how even after the government's acknowledgment of the expulsions and incarcerations of Japanese Canadians, the violence of the Internment is still actively denied and the witness to the violence is challenged and even punished for bearing witness. Naomi's experience helps to illustrate how space is critical to understanding how what is witnessed about the Canadian nation by Japanese Canadians and what is understood of these analyses by nonJapanese Canadians is always mediated by social relations of power.

Naomi's experiences of schooling led her to develop strategies for dealing with the violence of that space. She acknowledges the support she has received from her mother and sister with whom she can discuss what occurs in their daily lives. She credits her mother for sharing her "insights" with her gleaned from her life experience. She adds, "I feel really, reaily lucky that I've had that because I know a lot of people of colour that are going to university with me don't have that [support]." 73 She, along with other students, formed a students of colour group "to try and be a support system for each other and also try and change the kind of institutionalized racism and white supremacy that we felt was going on." ${ }^{74}$ She says she also keeps lists of things that occur in the classroom and has addressed some of her concerns to the administration of the university. She states, "It was very empowering. Nothing happened but it was still empowering."

In this section, we have seen how the space of schooling in various geographical locations can be a space of violence for racialized children. That children are taught from 
a very early age the "sticks and stones" adage of racist language as benign and merely words is part of the process of the forgetting of racist violence. As Mari Matsuda and others have argued, racist speech are "words that wound,"76 and can be a form of "spirit murder"77. I have tried to be cautious in my repetition of racist language because of the harm these words have inflicted upon the women testifying and also on other people of colour. That women can remember particular incidents of racism with such clarity and describe and even name the perpetrators is indicative of how it has cognitively and emotionally been mnemonically inscribed. I would argue that these testimonies describing racism are reflective of its psychological impact and the early "trauma of racism." 78 Midori told me that she remembers being regularly assailed with anti-Japanese and antiChinese language by a white boy in grade nine. She refers to this experience as "traumatizing... because I still think about it now."

In the mnemonic encounter between Japanese Canadians and white people, racist speech testifies to the dominant subject's imagining of the nation as white in defiance of Japanese Canadian women's assertion to enter white-dominated spaces and imagine the nation differently. Thus the forgetting of who has been and must be removed in producing white spaces is also about a reiterative memory formation for dominant subjects. The imagining of the nation as white necessitates this forgetting and racist speech reinscribes the violence forgotten. These violent encounters, however, not only mark the position of the Japanese Canadian/Asian Canadian subject within the nation state but also reveal the cracks in the mythology of the nation as an always stable entity. As is stated by Laura Hyun Yi Kang, “A solid 'presence' of nationality can be conceived only through the virulent marking out of various alien-others for exclusion and repression but these very gestures of negation...can reveal the uncertainty and instability of that very national identity." 80 Homi Bhabha also contends that "the racist gaze" enunciated through "racist stereotypes, statements, jokes, myths" reveals the "narcissism and paranoia" of the figure of domination. It is through these representational admissions that the figure of domination loses its "representational authority" by revealing the "phobic myth of the undifferentiated whole white body." 81 Yet it must be underlined that the violence unleashed through these repetitive processes of re-stabilization of the national identity and hegemonic subject produce lived harms of enormous consequence. 
The forgetting of violence perpetrated upon certain communities is promulgated through curricula that do not teach how this violence has occurred and is occurring. In speaking about the curriculum in the United States, Don Nakanishi has stated, "although the bulk of the literature on the Internment appeared during the twenty-year period following the war, very little found its way to American textbooks or the mass media."8? Although the Canadian context differs in that very little literature was generated on the Canadian incarcerations in the period immediately following the Internment, there are now multiple interdisciplinary representations with which to engage through the curriculum. It would seem, however, that it is not the availability of materials that determines the curriculum guidelines but rather the ideological framework of the ministry of education in each province and the decisions guiding the implementation of these standards at the levels of municipal government, school boards, individual school, and classroom. Recent changes developed by the Ontario provincial government led by the Progressive Conservative party proposed deleting "anti-violence prevention....antidiscrimination training...(and) education about native people." 83 The government's history curriculum guidelines omitted "any reference to the African slave trade in North America or the internment of Japanese Canadians during the second world war." addition, the Toronto school board equity programs are being dismantled, including antihomophobia and anti-sexism initiatives, resulting in community groups struggling with and against each other over curriculum and resources.

Children, however, take note of pedagogical amnesia and carry the dissonance between the notion of nation they inherit from family and community spaces and that which they encounter represented in the space of school. The spaces of school, family, community, nation must not therefore be seen as discrete and separate. Managing the trauma of everyday oppression is a responsibility that a child carries through all the spaces of her existence.

That so many women chose to intellectually and creatively engage with the legacy of the Internment in an environment where this history was suppressed, I would argue, reflects a prior epistemic acquisition of the Internment. Women had to "know" something about the incarcerations in order to even conceptualize and propose it as a subject of research. The seeds of that episteme were planted in the space of family and/or Japanese 
Canadian community, in contrast, from most accounts, to the space of school where their subjugated knowledge met with a barren silence.

To only see the daughter of the survivor or the subject speaking as the source of representation denies how knowledge and memory are multiply constituted; it denies how knowledge is imparted within the family and/or Japanese Canadian community space and how the subject brings her knowledge of those spaces into other spaces, transforming absences into presence. It also occludes how access to different spaces is socially constituted and how spaces are hierarchized, with work done in "respectable" white public spaces recognized in ways that emphasize its intellectual and creative independence from spaces less esteemed. I would suggest we re-think the simplistic binary constitution of the child of survivors as "speaking" and the parent survivor as "silent," and recognize the complex spatial negotiations of remembering from differently located subjectivities. In this way, perhaps we will begin to dismantle the reification of the autonomous subject and acknowledge the ways in which our knowledge of violence and oppression, and our resistance to domination depend upon our connectedness to a community who remembers.

That so many of the women accomplished projects "on the Internment," within these settings, is a testament to these women and a reflection of a profound desire to articulate and represent in their own ways, the legacy of the violence done to their families and loved ones. However, the school must not be reified as a site of such knowledge production. As Haru stressed, education is a class-related activity and postsecondary education in particular is for the most part accessible only to middle-class students and the economic elite. My focus on the school stems from realizing its critical spatial relationship to nation, a site where most children spend some time and where children from subordinated communities experience violence.

It is revealing, however, that women could see the intellectual significance of the Internment across various disciplinary spaces, including sociology, geography, and women's studies. The curricular consignment of the Internment to the study of World War II alone is also a function of disciplinary containment. Envisioning multiple discursive interventions across disciplinary categories interrogates the ways in which knowledge of violence is contained in intellectual production and contests, through the 
embodiment of present witnesses, the temporal relegation of the Internment as a past and therefore "forgettable" historical event.

All of the women who worked on these projects did them within the curricular framework of "choose any topic" and where they alone were "marked" for acquiring this knowledge. Some were rewarded institutionally for completing these projects by achieving good grades, yet most had little material support from their instructors. What would it be like for students to be supported intellectually and emotionally for undertaking the difficult work on examining their histories of violence and not just simply be "allowed" to attempt this work? Eiko's feeling, for example, that she was perhaps "naive" to undertake the study of the "psychological and sociological" effects of the Internment reflects the ways in which the "inheritor" of the Internment is left to internalize what is "unknowable" about this history as a personal limitation rather than evidence of its complexity and necessary "forgetability" within spaces of domination. That the issue of the effects of the Internment are still under-explored in the Canadian theoretical literature speaks enormously of how Eiko's work was ground-breaking and foreshadowed the concerns of her's and subsequent generations.

In writing this section, I have come to hear myself through many of he stories told to me by women who attended schools in various communities, "after the Internment." I also acknowledge the many "silences" I have encountered within the space of schooling, only ever attending two classes as a student where the Internment was a part of the curriculum - a class at the graduate level where Obasan was taught and another graduate course taught by a visiting white historian from the United States, whose area of scholarship was the Internment of Japanese Americans. Any attention given to the Internment in other courses I have attended has been the result of work I have done in insisting it be addressed. Like Naomi, I have been challenged for undertaking this work at a university, not however by professors, but by fellow students at the graduate level. Two incidents stand out: a white feminist scholar who told me I needed to think about how the government was "protecting" Japanese Canadians by expelling them from the B.C. coast; and a white man, a teacher at a private boys' school, who refused to believe that Prime Minister Mackenzie King ever used racist language to describe Japanese Canadians, even though documentation of this usage was shown to him. 
The lack of curricular attention to subordinated histories is part of the social construction of what I have been naming in this thesis as the collective national forgetting of the Internment and it is a forgetting that can be violently defended when confronted by remembering, as is witnessed in Naomi and my testimonies. But it is also pedagogically questionable to include a lesson on the Internment, for example, only because there is a Japanese Canadian student in the classroom (determined as "the" subject of that history) and to allow the body of that student to become the lesson. In this way, we continue to deny how the Internment and other histories of violence are constitutive of everyone's history within the classroom, part of the making of nation and its citizens.

Before I began to interview women, I held the belief that educational institutions could be a site of insurgency for students. In learning from the women I interviewed and in re-membering my own experiences and those of friends and colleagues, I am more clearly understanding this space as one where violence occurs against students from subordinated communities. Violence is mobilized through various means and various bodies, and I cannot allow myself to forget that these violent practices are more probabilities than unlikelihoods. There are contestatory discourses occurring within the space of school and the work that these women have done within these spaces of education is evidence of an extraordinary resistance to forgetting. Yet, as we have seen, this work is usually done with little institutional support, within the context of "it could be any topic," and there are also the possibilities that such work will be demeaned and penalized.

In regards to teaching children traumatic texts, Simon and Armitage-Simon have concluded,

If teachers have little background information about a historical event and its context, and have neither resolved the questions such stories elicit nor found a way to live with the unknowability of many of the questions they raise, perhaps they should not incorporate these stories in their curriculum. ${ }^{85}$

Mere inclusion of the Internment or any other representation of historical violence in curriculum is insufficient and even potentially damaging. While I have been inspired by all the women I have interviewed who struggle to remember and have so generously handed across their memories to others and to me, I also see the pain in this continual 
negotiation and the violence that lurks below the surface of mnemonic encounters with forgetting. In my conclusion, I will propose strategies for supporting the generations of the Internment who continue to struggle to remember. I will now turn to an examination of the knowledge produced by women and how they hand across this knowledge in various social spaces, offering a counter-memory to the hegemonic notion of the Canadian nation.

\section{Section Two}

\section{Remembering the Internment in White Spaces}

Kyo described an encounter she had with a white woman working for the Ontario Progressive Conservative party in an election. As the woman began to defend her party's policies, Kyo retorted these policies discriminated against poor people, women, and people of colour. When she was asked about racism, the woman replied, "Racism doesn't exist." When Kyo informed her that she was called racist names on the street, the woman denied her experience by saying "That doesn't happen." Kyo replied, "It doesn't exist for you." The woman then added, "Your people are so respected in our community." When Kyo reminded her of the events of the 1940s, the woman replied, "Well, except for that incident. I forgot about that." ${ }^{86}$ Kyo explained this as her strategy, "Making [racism] political is a way for me to survive, a way to resist." 87

This example introduces the final section of this chapter and emphasizes the ways in which women continue to negotiate their memories of the Internment through white spaces of forgetting. In these mnemonic encounters, we see how the forgetting of violence is reiterated and the nation as "our community" is continually normalized as white by white people. Bearing witness to the Internment is not just about remembering it in historical isolation but it is also about how the knowledge conveyed by its import informs the struggles of women in the present.

Japanese Canadians encounter the forgetting of the Internment in different ways. Another kind of mnemonic encounter occurs when white people "confess" their "ignorance" of the Internment to Japanese Canadians. ${ }^{88}$ In this confessional engagement, Japanese Canadians are held responsible for acting as pedagogical witness for the "ignorant" confessor. Although there was a nation of white witnesses and beneficiaries to 
the Internment, it is doubtful that they are called upon to remember the Internment in this way. While these encounters can be invasive to say the least, they also map the various silences produced by white people, occurring in our spaces of existence and who is held accountable for speaking in these spaces. While I have been arguing for the importance of memory in our reconstructing of knowledge of the Internment and the subject(s) of violence, I do not feel it is our responsibility to act as the confessional for a nation's forgetting or to give absolution to those who attempt to perform their innocence.

Louise described to me how whenever the Internment enters public discourse, people approach her saying, "We didn't know this happened to the Japanese people.... Did it happen to you? And were you affected? And it was awful and all this sort of thing." 89 These confessional encounters were especially heightened for her during the redress struggle. While Louise will respond to some questions when asked, she adds, "It's not something I bring up." ${ }^{90}$ Demands to meet the needs of confessors/interrogators once again demonstrate how relations of power construct memory and forgetting. To hold Japanese Canadians alone accountable for remembering and speaking about the Internment is to deny how forgetting is continually reinstituted by non-Japanese Canadians through white spaces and how our choosing not to remember or speak in these spaces is also about our remembrance of the violence forgotten and the potentiality of violence hovering beneath the surface of these mnemonic encounters. Negotiating our memories in these encounters is also then about "how and where women see dominance." $" 91$

These mnemonic encounters extend beyond the specific discourses of Internment (although I would argue they are connected to them) and occur when we enter various white spaces. Eiko told me her mother had been recently approached by a white woman who "confessed" something she had done to a Japanese Canadian man just after the Internment: "Years later, she confessed all this to my mother who she didn't even know." 92 


\section{Resisting Domination in White Spaces}

Women described to me how they continue to experience people's racializing and en-gendering practices in the present. While I cannot detail the many examples that all women cited, I have included some of them in this section. What is clear from the testimonies of all of the women interviewed is how they continue to confront a hegemonic notion of nation in different ways and how they use their understandings of their histories of Internment in analyzing and contesting domination. Admittedly, systems of domination are not static but shift over time and are geographically specific. David Goldberg's concept of "racisms" is useful in conveying the historically and geographically specific mobilizations of racial domination, for example. ${ }^{93}$ The economic and social power accrued from domination must continually be fought against and challenged. I have described how women have been handed down the memory and knowledge of the Internment, but white subjects are also handing down their conceptions of nation and citizenship. As we shall see in this section, hegemonic notions of the nation and citizenship still produce the nation as variously exclusive and Japanese Canadian women continue to name and contest these exclusions.

Irene described how "racist words" are used against her in Toronto and take various anti-Asian forms: "A white European gentleman passed me in the street once and said something derogatory about Koreans and how we should all go back to our country." She also notes how one of her childhood friends always refers to her as "her Japanese Canadian friend," which she finds offensive. "It's how she views the world. In specific categories," that marks her in this relationship. ${ }^{95}$

Sylvia reported she had been to St. Catharines, Ontario, and as she was driving into town, a young white man passing in his car, yelled out of the window an anti-Chinese racist word. Both Irene's and Sylvia's reports of being the targets of anti-Asian hate language illustrate how Asians are "imagined outside the political community" imagined to be essentially the same. As McAllister states, this non-differentiated sign of the Asian "becomes a flexible image that can be loaded with changing national anxieties." 97 Getting the "Asian origin" wrong (we aren't Chinese) is not the point. It is rather the origins of practices that legitimize and normalize the marking out of spaces of white entitlement and monopoly: the repetitive citation of the exclusion of Asians, 
Aboriginal people, and people of colour, discursively and materially reinforced through violence in the form of hate speech.

Sylvia also reminds us that racism cannot be separated from sexism in understanding incidents where our bodies are marked for exclusion. She sees this when she and other Asian women are referred to as a "girls" and not "real" women: "I'd be in situations where a white woman my age would be calling me 'dear' or refer to me as a 'girl'." 98 Laura Hyun Yi Kang also sees in this infantilization of Asian women or the "emphasis on [their] youth" as echoing "both patriarchal and colonial representational modes of reducing these women as subjects." 99

Asian women within the white Canadian imaginary occupy particular job categories. In this "national fantasy," 100 Asian women are seen as subordinate to white people. Sylvia explained how her cousins were asked whether they were their mixed-race children's "nannies" while walking in their neighbourhoods. ${ }^{101}$ These responses indicated that the children were perceived to be white and the relationship between an Asian woman and a white child was immediately construed as that of worker and white employer.

Kyo reported she does not enjoy travelling with her white male partner to towns or rural areas in Ontario. "It's really obvious when people stare at us.... I don't know whether they're staring at me or they're staring at us because we're an interracial couple." 102 Her comment, "the way [my partner] experiences [a rural area] and the way I experience it are two different things," 103 indicates how the same space is experienced differently, contingent upon how one's body is perceived in relation to that space. Women often talk about their experience of racism in relation to the spaces they inhabit or visit. Incidents of racism in these various spaces indicate how white subjects continually must mark the space as white in order to recreate the myth of white ownership. That people of colour are regularly verbally assaulted in this way is constitutive of a violence that is continually forgotten, minimized as "isolated" incidents and "merely" words. As Sylvia points out, for women of colour, racializing practices that seek to contain or diminish us are also part of the ways in which we are en-gendered through relations of domination. 
In Vancouver, Midori reported recently seeing a wall of the spectacular ocean walkway in Kitsilano spray painted with the words, "Japs Go Home." When she saw the racist slogan, it reminded her of what happened "fifty years ago." 104 Midori's accounts of being "sporadically" the target of racist language while walking on the street also gives lie to the mythologizing of large Canadian cities as "multicultural" havens.

May also indicated how she is reminded of her incarceration when she reencounters racism and draws upon her experience in analyzing violence: "When you've gone through, knowing the evacuation and all of that happened...it scared me, for instance, when that young Chinese man was beaten to death in Detroit...he was killed by mistake... [the killers] were protesting against Japanese cars...."105

That women continually struggle with systems of oppression has been evident throughout this thesis. May was only one of two women I interviewed who used the term "shikata ga nai" in describing how one might deal with the violence of the Internment. When we hear her testimony, it is clear that what the term signifies for her is the pain incurred through loss and the understanding that the losses are irretrievable. This explanation of how she has coped with the losses sustained through the Internment arose when I asked her about the possessions her mother had left with friends in Vancouver. Taking a job as a domestic worker, leaving behind her mother and sister in the prison camp, supporting her family with her wages, and going to school in a community where she knew no one did not avail her with the time nor energy needed to track down her family's possessions. She explained, "I learned that was one of the things you learn to do to survive was to let things go.... So it was a way of dealing with the pain. You know, Japanese say, 'shikata ga nai'." 106 This is not about capitulation or the fixity conveyed through the term "silence"; it is about the complex negotiation of dealing with violence and its effects while trying to survive them.

Ann illustrated how she dealt with the racism she experienced after she moved to Ontario. She was worried about her son having to attend a rural school and they eventually moved to the town of Chatham. Here her son was attacked by other nonJapanese Canadian students of colour. She said he defended himself from the attacks and that he must have drawn from "her nature" in learning to challenge the attackers. ${ }^{107}$ She added, "there was a lot of that when I was growing up, too."108 
What does not always get conveyed through representations of Japanese

Canadians are the processes of struggle in surviving the Internment, its consequences, and the other forms of social domination encountered after the dispersal. These struggles and negotiations were and are continuous and are not just singular, as one might come to believe from the way in which the redress campaign becomes monumentalized as a unique moment of struggle and resistance. May had to continue to struggle to ensure the survival of her family and she channelled her resources into this commitment. As we have seen, people continued to confront oppression in the many spaces to which they were sent as they were dispersed by the government. May told me that married women in the 1940s were not allowed to work for the government. As a result. she was fired from her clerical job when she married. Her disapproval of this practice was known by some of her coworkers and within a year of her dismissal she spoke on a panel for the civil service association expressing her criticism of this discrimination against women. The panel discussion took place in the late 1940s. "I really do like speaking up and I have sometimes very definite opinions," she emphasized. ${ }^{109}$

Women continue to negotiate their interpellation as racialized and gendered subjects in different spaces of existence. Evelyn described to me how she felt people in her British Columbia environment reacted to her "mixed marriage" as a "novelty." "I0 She then told me how she had gone to the bank and wanted to withdraw money from their familial account and the staff, "looked at me as if they doubted I was that person." "She added, "But then I wouldn't be thinking of it as discrimination. Maybe I was naive."112 Continually being questioned by others on the basis of their constructions of us as racialized women can be unnerving, causing one to question oneself and one's understandings of each situation. These moments of "ambivalence" and "disorientation" are responses to the ways we are constructed as Japanese Canadian/Asian women and questioned as to our right to place within the space imagined as white by the interrogator. Our responses in a particular moment do not determine future actions and different situations may engage different responses, but I would argue that the space of ambivalence is one from which we can produce contestatory responses and constructions of ourselves. After describing her community to me, Evelyn then told me how she knows racism exists in her town and gave the example of the school system. She described the 
situation of South Asian students and their experiences in the schools as "horrifying." "It's removing their dignity, removing their self-confidence as students." she explained." As a result, she became involved in instigating "an anti-discrimination policy" with the schools.

In thinking about her own experiences of racism, Janice described how she had witnessed her mother ask a "big, burly" white man seated behind them at a hockey game to stop disturbing people. He replied with racist language and the comment, "Why don't you just go back to where you came from." 14 Her mother stood up and said, among other things, "I'll have you know, I was born in this country." "15 Janice's memory of the man's response was that he shrunk into his seat. Janice, however, said she felt uncomfortable with this confrontation because it was a very public exchange. Her comment reveals how women continually negotiate their responses to racism and how children may feel ambivalent towards their parents' not speaking and speaking about the violence they have experienced. Perhaps the ambivalence we feel in these moments can be used to look beyond our parents' and our own behaviours as its cause, situating its sources in the exclusionary spaces we variously experience as racialized women and men.

When I asked Mayumi about her experiences of racism as a child, she responded by telling me of her current situation and a complaint she has submitted to the Human Rights Commission. She was able to discuss the complaint with her mother before it was launched and describes her response as "If you think it's wrong, then you have to do whatever you think is right." 116 While my thesis has focused upon certain historical moments in these women's lives, I do not wish to portray the mother-daughter or familial relationships as frozen in time. Women continue to negotiate the memories of the Internment and their knowledge of oppression in all of their relationships, while seeking to build spaces of support.

\section{Conclusion}

In this chapter I have discussed how women resist the forgetting of the Internment in the white space of school and in other white-dominated spaces. In school spaces, female children are variously confronted with racist, gendered, ableist, heterosexist and other forms of violence through speech acts uttered by dominant subjects or those 
subjects seeking to be dominant. They are also marked in various ways through discourses and practices of "othering." These enfigurations of domination within the space of school, where certain bodies are singled out in different ways, map the exclusions within a nation where the model for citizenship is continually imagined as the mirror reflection of the hegemonic white bourgeois subject. The forgetting of the history of Internment within this space is critical to this imagining and when this story is seemingly allowed narration, it must necessarily be contained, so that the extent of the violence does not disrupt the corollary component to imagining the nation of Canada as white and that is its construction as benevolent. In the mnemonic encounter with a hegemonic forgetting of the Internment, women resist through remembering in distinct and diverse ways. In resisting through the spaces of forgetting, women's subjugated knowledge of the Internment can be mobilized to contest the systems of domination inherent in these hegemonic notions of nation, citizenship, and the subject.

\section{Endnotes: Chapter Nine}

1. Adapted from a line in Janice Mirikitani's poem, "Generations of Women,": "We will come like autumn shedding sleep/a sky about to open with rage,/thunder on high rocks. $/$ crush the white wall/with my name." Mirikitani, "Generations of Women," in Mirikitani. Shedding Silence, p. 15.

2. Lustiger-Thaler, "Remembering Forgetfully," p.196.

3. Nagata, Legacy of Injustice, p.113.

4. Interview with Margaret, p.51.

5. Interview with Louise, p.81.

6. Interview with Esther, p.55.

7. Interview with Haru, p.77.

8. From an analysis of 1986 census data, Audrey Kobayashi concludes that "close to half of Japanese Canadians under age $\mathbf{4 5}$ have some university education, and about one quarter hold university degrees.... Canadians as a whole are about one fifth having some university education, and about 10 percent holding a university degree." Kobayashi, "A Demographic Profile of Japanese Canadians," p.39.

9. The gender of the teachers was not always reported. 
10. Interview with Mayumi, p.8.

11. Ibid., p.22.

12. Interview with Haru, p.77.

13. Ibid., p.78.

14. Ibid.

15. Ibid.

16. Interview with Yuko, p.9.

17. Ibid., p.10.

18. Ibid., p.16.

19. Ibid.,p.10.

20. Interview with Sylvia, p.8.

21. Ibid.

22. Ibid., p.17.

23. Interview with Irene, p.27.

24. Ibid., p.27.

25. Ibid., p.29.

26. Ibid.

27. Ibid.

28. Ibid.

29. Interview with Midori, p.19.

30. Ibid.

31. Ibid.

32. Interview with Joanne, p.10.

33. Ibid., p.62.

34. Lowe, Immigrant Acts, p.55. 
35. Ibid.

36. Interview with Janice, p.7.

37. Ibid.

38. Ibid., p. 41 .

39. Ibid., p.15.

40. Ibid., p.21.

41. ㅁid.

42. Ibid., p.21.

43. Ibid., p.22.

44. Ibid., p.21.

45. Interview with Naomi, p.9.

46. Ibid., p. 10.

47. Ibid., p.11.

48. Ibid., p. 10.

49. Ibid., p. 14.

50. $\underline{\text { Ibid. }}$.

51. Ibid., p. 16.

52. Ibid., p.28.

53. Razack, Locking White People in the Eye, p. 167.

54. Interview with Kyo, p.15.

55. Ibid.

56. Ibid., p. 16.

57. Ibid.

58. Ibid.

59. ㅁid. 
60. Interview with Eiko, p.54.

61. Ibid.

62. Ibid.

63. Interview with Kyo, p.17.

64. Interview with Janice, p.22.

65. Interview with Sylvia, p.17.

66. Ibid., p.18.

67. Interview with Yuko, p.15.

68. ㅁid.

69. Ibid., p.16.

70. Interview with Naomi, p.29.

7 I. Ibid., p.30.

72. Ibid., pp.31-33.

73. Ibid., p.46.

74. Ibid.

75. Ibid., p.48.

76. Mari J. Matsuda, Charles R. Lawrence III, Richard Delgado, and Kimberlè Williams Crenshaw, Words That Wound: Critical Race Theory, Assaultive Speech, and the First Amendment (Boulder, CO: Westview Press, 1993).

77. Patricia Williams quoted in Matsuda, et al., Words That Wound, p.24.

78. Chalsa Loo, “An Integrative-Sequential Treatment Model,” p.90.

79. Interview with Midori, pp.15-16.

80. Kang, "Compositional Subjects," p.130.

81. Homi Bhabha, The Location of Culture (London and New York: Routledge. 1995), pp.91-92.

82. Nakanishi, "Surviving," p.16. 
83. Enzo Di Matteo, "Tories Slam Book on Anti-Racist Schooling," Now 18, 7 (October $15-21,1998)$, p.24.

84. Ibid.

85. Simon and Armitage-Simon, "Teaching Risky Stories," p.30.

86. Interview with Kyo, p.82.

87. Ibid.

88. See Lustiger-Thaler's description of how Jews who moved to Germany from other parts of Europe, after the Holocaust, were placed in the position of "playing 'confessors" to German 'sinners' through the good offices of the philosemitic state." The Christian symbolism of this metaphor is also of interest here. Lustiger-Thaler, "Remembering Forgetfully," p.196.

89. Interview with Louise, p.82.

90. lid., p.83.

91. Trinh T. Minh-ha quoted in Yeğenoğlu, Colonial Fantasies, note 82, p. 154.

92. Interview with Eiko, pp.88-89.

93. Goldberg, Racist Culture, p.97.

94. Interview with Irene, p.75.

95. Ibid., p.76.

96. McAllister, “Asians in Hollywood,” p. 13.

97. Ibid., p.10.

98. Interview with Sylvia, p.28.

99. Kang, “Compositional Subjects," p.221.

100. Lauren Berlant, The Anatomy of National Fantasy. Chicago and London: University of Chicago Press, 1991.

101. Interview with Sylvia, p.58.

102. Interview with Kyo, p.30.

103 Ibid., p.31.

104. Interview with Midori, p.109. 
105. Interview with May, p.78. The "mistake" she is referring to is that the killers claimed they believed Vincent was Japanese. For a filmic representation of the incidents surrounding the Chin murder, see, Christine Choy and Renee Tajima (directors), Who Killed Vincent Chin? (New York: Filmmakers Library, 1988); for a textual account, see Takaki, Strangers from a Different Shore, pp.481-484.

106. Interview with May, p.44.

107. Interview with Ann, p.76

108. Ibid.

109. Ibid., p.62.

110. Interview with Evelyn, p.78.

111. Ibid.

112. Ibid., p.79.

113. Ibid.

114. Interview with Janice, p.17.

115. Ibid.

116. Interview with Mayumi, pp.12-13. 


\section{Conclusion \\ Re-Imagining Nation, Citizenship, the SubJect}

In this thesis, I have argued that violence was committed through the expulsion, incarcerations, dispossession, displacements, and deportations of Japanese Canadians. The sites of incarceration and displacement were discursively and materially interconnected through interlocking systems of domination, en-gendering women and men through processes of incarceration and forced labour, and the destruction of the social and economic arrangements of families and communities.

The representation of Canada as a tolerant and benevolent country, nationally and internationally, necessitates a forgetting of the violence done within the nation space. When violence occurs, its representation must be contained in various ways. The forgetting of the violence of the Internment, a violence that was critical in reinsinuating Canada as a space of white supremacy and hence constructing the Canadian nation as white, is not a passive, fixed process but must be continually reiterated through the containment of what is admitted and remembered. What and who is remembered, and what is forgorten are therefore reflective of social relations of power. The discourse of the silent Internment survivor is part of this process of forgetting and I have attempted to interrogate its raced and gendered insinuations, and raise questions about whose silences are measured and whose silences are forgotten. Survivors of the Internment and their children offer a counter-memory to the forgetting of the violence and while memory is not intrinsically counter-hegemonic, the memories of these women have revealed subjugated knowledges that offer possibilities for re-imagining nation, citizenship, and subjects.

In remembering the resistance that we develop in present communal arrangements, we must also remember the origins of our spatializations, including the violence that forced Japanese Canadians to these dispersed spaces and how violence continues in multiple exclusionary forms. In the displacements caused by hegemonies of capitalism, globalization, colonialism, and imperialism we must recognize how the right to place is secured in relation to placelessness. Despite attempts to relegate the Internment to the "past," we must not forget that the violence of the expulsion mapped out spaces of 
dispersed existence for Japanese Canadians and spaces of entitlement for white bourgeois subjects, and was formative in the continual hierarchical arrangement of all people residing within the Canadian nation.

My attempt to understand the spatial construction of the Internment also engages some discussion of what these spaces produced and continue to produce across generations of Japanese Canadians and also for non-Japanese Canadian citizens of Canada. Part of the violence experienced through these spaces was the disruption and destruction of families, relationships, and communities. There are numerous other ways in which violence touched each person's life and the complex and painful effects of the Internment can never be claimed to be known by those of us who did not undergo these experiences of incarceration and displacement. My work is an attempt to resist the violence of this history, my way of witnessing a profound familial and communal legacy.

I end this thesis by also admitting that my focus upon the violence of the Internment and its legacy has foreshadowed the illumination of the testimonies of the women interviewed in all their complexities. Despite the limits of my work, I still maintain that we must work toward understanding how we live relationally as heterogeneous subjects and how we might continue to build collectivities who resist domination. In recognizing our heterogeneous interconnectedness we may be better able to envision new cultural forms "that do not depend upon privileging a singular subject as the representative of the group, conceptions of collectivity that do not prescribe a singular narrative of emancipation."' The women I have interviewed may not agree with the conclusions I have reached through this project and I alone am accountable to them for my representations of their words and ideas. The possibilities I construe from their testimonies, however, are generated from their insights which they so generously provided to me and for which I am extremely grateful.

The hope that I have felt through this project is attributable to the gift of possibilities for ways of being and living differently that women have offered us. The connections to others remembered and built by women, and their generosity in sharing their testimonies with me and with all who read this work have deeply moved me and taught me enormously about how to remember and how to work toward resisting and challenging oppression. This conclusion to my thesis seeks not to narrate a redemptive 
closure to our history of violence in this country. I know that others in the multiply situated Japanese Canadian spaces within this nation space will continue to remember in their own ways and perhaps respond to the ways in which I have remembered. This work is but a beginning, contingently produced in relation with the people I have interviewed and the many people through whose work, friendship, and example I have found inspiration and hope. It is offered in the desire that we might always remember how we are interconnected and connected to other communities with whom we share national and transnational spaces, and that within our imagined communities we will seek creative possibilities for challenging domination in all its forms.

\section{Imagining Nation Differently}

Women continue to struggle with the memory of their individual and communal losses and those sustained by other subordinated communities in relation to a collective notion of nation. If the nation is imagined as a white and benevolent space, then certain people and practices must be continually forgotten in order to maintain the hegemony of the national mythology. As Foucault suggests, the exertion of power necessarily meets with resistance in varying forms and throughout this thesis we have witnessed the heterogeneous ways in which women resisted the violence of the Internment, its legacy, and the multiple forms of domination to which they have been subsequently subjected. In proposing we re-imagine the Canadian nation, it is not suggested that we can or should therefore make a really "benevolent" nation, as I am uncertain that any form of nation is possible without violence and exclusion. Rather, I am proposing that we need to first reimagine Canada, and admit how the mythologized homogeneous construct of this nation is procured through violent systems of domination generated in multiple spatial arrangements, in order to conceptualize how we live in and produce spaces that are interconnected within and outside of national territories.

The ongoing struggle against the forgetting of the Internment was most cogently expressed when I asked women their impressions of the 1988 redress settlement with the Canadian government. While I have been unable to examine this historical struggle in detail, I would propose that further research be done on the relationship of redress to the production of memory. Alice Yang Murray has suggested that mobilizations of survivors' 
memories were critical to the redress movement in the United States. ${ }^{2}$ It is also clear that survivors' memories were critical to the initiation and execution of the Canadian redress struggle. As was seen in Chapter Eight, the activities of the redress movement supported the discussion of the Internment within some familial contexts. Yet despite the government's acknowledgment, women's testimonies indicate that remembering the Internment in different spaces is still met with hostility and forgetting.

Some examples will be cited from my conversations with women on the redress settlement. These testimonies convey how women's images of nation are different from the benevolent one reiterated even within the written text of the redress agreement itself. Many of the women, such as Aya, expressed appreciation for the work that was done by Japanese Canadians who participated in the redress struggle. Nevertheless, while the government on behalf of Canadian citizens may have sought closure with this agreement, the women I interviewed see redress as part of an ongoing struggle to remember and imagine a nation space that is different from one presented as always ever benevolent, in the hope that "it won't happen again."3 As Kirsten Emiko McAllister states, "the redress movement in itself was not capable of resolving the violations of the past nor issues and concerns that faced the contemporary community."4

Evelyn defines redress as a "major contribution to Canadians." She adds, "It would never, never be able to compensate for all that they have robbed. But financial compensation is a recognition of the wrong they have done to Japanese Canadians." Evelyn believes that one direct effect of redress will be a change in educational curriculum, a change to what is taught as Canadian history. For without redress, she feels, her history of incarceration would not have been recognized as "history." In this way, she imagines the Japanese Canadian space of struggle that resulted in redress as affecting the spaces of education for children and adults, promoting an epistemological shift in how they view the history of Canada. She concludes, "One hopes that the government having had to [make redress] would think twice the next time."7

Margaret asserted that financial compensation was an essential component of the redress settlement. She is conscious that some people were critical of this part of the agreement with the government but maintains, "I'm not like some people saying, 'I don't want to touch that money." She also remembers other members of the community who 
died before the settlement was negotiated, "there were a lot of people who worked toward that end." 9

Kazuko raised the issue of the redress settlement when she asked me if I knew about the "money that we got from the government." 10 "It didn't take the place of everything we lost but it's something.... We had an apology from the Prime Minister, but that doesn't cover everything," she comments. "She explained how her father died before the settlement and how he had "lost everything," "the ten acres, the berry...farm...the chickens, the horses." "We have lost an awful lot," she emphasizes. ${ }^{13}$ When speaking about her daughter and the fact that she was born after the incarceration, Kazuko expressed her awareness and fear that others could be similarly treated, "I just hope it won't happen again."

Kazuko's daughter, Sylvia, also remembered her father as she discussed the redress settlement. "It's a very small sum of money. And the money obviously doesn't repair all of the hurts and the loss of property, etc." ${ }^{15}$ She also commented on how the amount of $\$ 21,000$ only went to those who were alive at the time the agreement was signed with the government, "My father had died before the settlement. A number of relatives had died." In her view, the settlement does not erase "the lasting wounds that even people in my generation feel." 16

Midori expressed how she was happy for her parents but thought the "hard part for a lot of people was that most of the Issei who really deserved it weren't around to receive it." 17 Louise also expressed her regret that her father had not lived to see redress accomplished and that her father-in-law had not lived to receive the acknowledgment. She also emphasizes the elders' losses of property and rights, but thinks the settlement was good in acknowledging the government "had done wrong." 18

Haru also regretted that her husband died before the redress settlement was finalized and "he wasn't here to see that day." time during and after the incarcerations. "They went through the war, they all had to start with nothing. My husband came out with one little canvas bag. So did I. Everybody did." 20 
Ann expressed her view on the redress settlement in this way:

I guess nobody gains by [redress], do they? At least I don't think so. I guess for most, a lot of us, it came too late. Like my husband didn't have much time to enjoy it. I guess the monetary thing is the least of it, isn' $t$ it? No matter how much of an apology we get, it'll never make up for those lost years. But the thought that is there says something, doesn't it? ${ }^{21}$

In this reply, much is said about the pain of the Internment, a pain that is lived and re-membered relationally.

Mayumi, Ann's daughter, also emphasized how her father was personally committed to the redress struggle and knew that a negotiated agreement had been reached, but died a few weeks before the cheque from the federal government arrived. "After everything he had been through and I know how he felt about it. But it never arrived," she states. ${ }^{22}$ Her mother's cheque arrived before his death and a few days after he died his cheque was delivered. Mayumi also finds it "interesting that [the government] did that at all" and acknowledges "how much work it took to get there."23 She concludes, however, "But that doesn't make it over. It doesn't make it okay."24

Eiko told me how her mother and father "gave a lot of the [redress money] away." 25 "They carefully went through their whole history and thought of all those places, people that had helped." She adds, "I really admired my parents for doing that. And they're not well-off."26

In each of these instances, women again situate themselves within a community remembered: those who did not live to see the promise of redress to the community upheld, those with whom we struggled and who struggled on our behalf, and those to whom we pass on the responsibility to continue to remember the losses sustained. It is in this handing across of the memories of the Internment that we must witness how the spaces of nation have been lived differently by different subjects. That women remember the nation as one where unjust incarceration, dispossession, and displacement of citizens occurred and can imagine this violence as an ever-present possibility is an open challenge to the benevolent image of Canada presented nationally and internationally. Kyo expressed her feeling that her knowledge of her parents' incarcerations has impressed upon her "how easily things can be pulled from under you with legal authority. And that's 
scary."27 She feels this knowledge informs what she does for "cultural survival" in relation to the ways in which she is constructed as a racialized woman.

The process of handing down the memories of the Internment continues and the need to remember attests to how there is a certain commitment to struggle with the meanings of these memories as witnesses situate themselves in relation to the nation space. Yuko told me "In terms of my historical place in Canada with Vancouver and all that, that's still yet for me to uncover and talk about with my family."28

The nation imagined as inhabited by white subjects is also imagined as one inhabited by heterosexuals. May used her understanding of subordination to analyze a Canadian church's position on homosexuality and the reaction by some church members. She explains how she witnessed how some of these members knew individual gay people and yet "were down on these people as a group of people." 29 She suggests that domination mobilized against other communities may be interlocking with how one experiences other forms of social domination: "Does that mean they know me but they would still be down on my people?"30

S. recalled how the Internment changed her "daily existence" and affected her education. ${ }^{31}$ She states:

"[it] was an experience that turned out - essential in someone's eyes but not good for the Japanese. I think we lost a great deal, and in a sense, if you were able to go back and think of all the small things that made the difference, then that's what we lost." 32

S. emphasizes how the Internment affected the health of her parents and she credits them and her mother in particular for supporting her close-knit family, "our mother...carried on and never gave up." ${ }^{33}$ Her mother, who wrote haiku and played koto, was asked to teach Japanese classes before the Internment but this dream was unfulfilled due to the incarcerations. When a family member accomplishes something they remember her by saying, "Mom would have been proud of us." 34 . thinks people have to learn that the Internment "shouldn't have happened in the first place. And so it shouldn't happen again...that would be a mistake not to tell future generations what happened. And [I] hope that they will learn from what's gone on and this evacuation that we went through." 35 
The history of Internment is also the history of displacement. As we saw in the case of Naomi's family, as some children grew older, they left the towns to which their families were dispersed in order to continue education or find work opportunities. Aya described to me how much of her year is spent travelling to see her children in different parts of the country. She proudly told me of her ten grandchildren and one greatgrandchild, most of whom she was separated from by great distances. Her commitment to maintaining these connections was expressed to me as she described her travelling itinerary for the coming year, the seventy-eighth year of her life. In the spring, she travels to help her daughter in British Columbia, cooking for her while she and her family harvest crops. She then travels to Toronto to see her daughter. Louise, and her grandchildren. She does this at least once a year. In the past year she had also visited a granddaughter in Calgary and attended the graduations of other grandchildren. "The years seem so short," she exclaimed. ${ }^{36}$

Ann also told me of her fifteen grandchildren and three great-grandchildren, the eldest being thirty years and the youngest seven months. The extended family is something that Sylvia also emphasizes in acknowledging her cousin, who has a wide circle of Japanese Canadian friends, and who "set[s] an example for [her]."37

While the familial construct is one in our community that is mobilized to discursively contest and defy the ways in which the government attempted to destroy our families and communities, we must not reify the hegemonic bourgeois family as the model for intimate and loving relationships. Women may choose not to have children or live with partners; women and men have intimate and loving relationships with same-sex partners; women and men live as single parents. People also live within social relationships that they would prefer not to denote as familial relations. May referred to the difficulties experienced by both her mother and sister, who were divorced "way back then." 38 In these close relationships between sisters and their mother, they learned to support one another by saying, "We are really something." 39

That women and men have struggled to maintain connections to each other across great and small geographical distances is part of the lesson I have accrued from these women. The labour women have invested in reconstituting families and communities in different forms in the various spaces of dispersal must not be underestimated or forgotten. 
How is it that this labour, this struggle disappears in the representation of women as "silent"? How can we remember the women in our community who have struggled against violence? In her awareness that Japanese Canadians are accused of not resisting during the Internment, Esther makes a comparison to how women have historically struggled against male domination and reminds us that being subordinated should not be confused with accepting subordination. "We are still fighting for change," she concludes. ${ }^{40}$ How can we re-imagine the spaces in which we inhabit, not as ones where nuclear family units assert their autonomy and secure hegemonic masculinity, heterosexuality, and class privilege, but as ones where women, men, and children struggle against the processes of domination to create loving, healthy relationships and communities?

Joanne proposes an image of community that she has built in relationship with other people. She calls these people her 'teachers', "close friends [who] are first generation Canadians or people who have a sense of something outside of that middle classness." 41 For her, resisting domination is about "actually changing the space of the violations against people," to present meaningful "possibilities for loving and living and producing." 42

The government, with the cooperation and assistance of non-Japanese Canadian citizens, separated Japanese Canadian families in different ways. As we have seen, the women interviewed reconstitute the family and the community through their remembering of the Internment. Their's are not stories of the autonomous subject unimplicated in the horrors experienced by others. Rather these narratives reconstruct the subject as one who struggled to maintain connections despite the violent attempts to destroy these complex social relations, a subject who remembers others and seeks out others with whom they may remember.

\section{Alternative Spaces}

Although my concerns regarding how the Internment is "taught" or handed down to subsequent generations focuses upon this history of national violence. they can also be more generalized as preoccupations regarding the need for our community to commit itself to critical pedagogy and engagement on how we are constructed as subjects of 
nation in relation to other subjects. While I see the necessity in advocating for changes in curriculum that include the teaching of the Internment in public schools, I have also raised some concerns in this regard in Chapter Nine. Esther pointed out to me that many Japanese Canadian teachers are committed to curriculum development on the Internment, including a Japanese Canadian Educators' Group in British Columbia. More work is needed in supporting the generation of curriculum materials and Japanese Canadian teachers who undertake this work. Curriculum development should ideally be done in collaboration with other subordinated communities in order to develop pedagogical strategies that take into account the contrapuntal spatialization of social domination.

It is my belief, as was stated in Chapter Nine, that the school as a site of knowledge production cannot be relied upon for support in developing a critical understanding of the Internment or other histories of violence. While I advocate a multispacialized approach to addressing the forgetting of this history, including curriculum changes and working with schools and teachers, I would also strongly advocate the creation of alternate spaces for this knowledge production and suggest that the community support these spaces materially.

If, as was argued in Chapter Eight, people need to imagine the spaces of incarceration in order to understand the meaning of those spaces, representational aids are needed to assist in this imagining. As a general comment, I would like to see funding generated to support representational work in our community. While there exist the grants awarded in many fields of endeavour through the Endowment Fund sponsored by the National Association of Japanese Canadians (NAJC), there is no fund in our community specifically targeted toward the support of representational work. This cultural production would include community-based projects, multi-media artistic representation, as well as academic research. Such representational work, as we have seen, can enhance the ways in which we develop an understanding of our community and its histories. We must also identify and keep in print critical texts, such as Ann Sunahara's book The Politics_of Racism. We cannot trust that critical representations will be supported by publishing houses or government funding sources and must strategize as to how to ensure that representational work is produced by people invested in the health of our community. 
We must also find ways of supporting community ventures that resist the forgetting of our community's incarceration. Projects such as the Nikkei Internment Memorial Centre that marks the site of New Denver as one where Japanese Canadians were incarcerated are important geographical reminders and necessary to a handed-down practice of commemoration. In a landscape where our community's expulsion, incarceration, and dispersal have been spatially and discursively obscured and normalized, we need to remember and mark these carceral spaces for ourselves and future generations.

Although our community and its members have been variously described as "silent" about the Internment, we (and I might add many non-Japanese Canadians) have in fact depended upon its oral transmission, inviting survivors to speak at special commemorative events, at educational functions, or be interviewed in projects such as this one. This dependence upon embodied transmission of the history was reinforced by one woman who asked me, "What happens when the last internment camp survivor dies?" While I believe the transmission of this history is incumbent on all of us and not just survivors, I understand that the relations of handing down the history will change in subsequent generations. Representational work is thus a vital part of attending to the desire of community members to articulate how Japanese Canadians define ourselves at particular historical junctures as well as addressing our need to see how others represent these processes.

Representational work is also occurring within family spaces. May described how her mother began to write her history and now her daughter Eiko "is really after me to get my story down." ${ }^{43}$ These individual projects may never be acknowledged publicly but they also inspire us to think of different ways in which we might hand across our knowledge.

Concomitant with the desire to produce representational work are the "enunciative responsibilities" for its accomplishment and circulation. As Kirsten Emiko McAllister has stated, we must work toward "critical cultural production" that is "self-reflexive" and creates the "capacity to discern and critique not only the efficacy of various actions, but the implications of its own epistemological framework." ${ }^{44}$ We need to create spaces where critical work on representation produced by and about Japanese Canadians is 
supported and encouraged. Given the dispersed nature of our various communities, the direct result of the incarcerations, we need to develop mechanisms for developing and distributing critical work across geographical spaces. While the issue of critiquing representations produced by and about Japanese Canadians is always a difficult one, especially when there are relatively so few of us, the academic response to the novel Obasan illustrates that many non-Japanese Canadians in various sites are generating critical commentaries about our work at the same time as problematic images of our community are also being produced and received uncritically. Spaces must be procured for this engagement by members of our community.

May underlined how her mother had been active in a community organization about which a book had been written. Her mother was not mentioned in the book and May feels "it hurt her." While May emphasized, "I don't think it was malice.... I think it was simply an oversight," she then speculated, "I also think that if it were a man who had done this [work] the oversight wouldn't have taken place." ${ }^{" 46}$ May reminds us that we must address how patriarchal and, I would add, heteronormative relations structure our work and our community.

Our preoccupation with the handing down of this history, as children of families who were incarcerated, evidenced through the prominence of the discourse of silence used to describe our elders leads me to pose the questions: "How will we hand down this history?"; and "How will we be portrayed by the generations after us?" Given that the need for this transmission has been identified, how can we develop supportive pedagogies and spaces for this handing down to our children? More work is needed in developing pedagogical strategies in dealing with the difficulties in communicating with children about the Internment. An understanding of trauma must be included in this discussion and supports must be provided to both learners and teachers engaging with this material. We need to provide supportive community spaces for this engagement both for parents and for children of all ages, some of whom may not have elder or younger familial members with whom they can discuss this history.

Finally, in relation to all the points presented in this section, I would emphasize that representing the Internment to others can be profoundly painful work and must be recognized as emotional, intellectual, and physical work, a process embedded within 
interlocking systems of domination. That so many survivors have worked for us in transmitting knowledge of the Internment to us and other communities are pedagogical acts that must not go unnoticed. That the work necessarily engages psychological processes of trauma also must be recognized and it is my hope that we can develop ways to include this understanding and develop non-pathologizing forms of support and care for those who are called upon to remember.

While I have focused in this thesis upon how relations of domination produce violence against Japanese Canadians, I also see the need to address how violence is also produced within the spaces of family and community. Just as we must name the violence promulgated through the Internment as wrong, we must also name violence exerted upon family and community members by Japanese Canadians as also unacceptable. We must find ways of acknowledging how systems of domination produce us hierarchically and relationally within the family and community, and challenge these systems by supporting efforts that name these relations and struggle to change them.

While my use of the term "community" in this section is sometimes vague. I see myself addressing many different communities to whom I am connected. Although the history of the Internment is inherited by Japanese Canadian communities in particularized ways, I have argued that the Canadian nation is built, in part, upon this violence and is thus part of the historical legacy shared by all who imagine themselves as Canadian citizens. In addition, I do not envision the Japanese Canadian community as one monolithic community. Naomi emphasized in her expression of alienation from some community activities that she also constitutes herself as being connected to her Japanese Canadian family members and friends. She feels the Japanese Canadian community has "a lot of different parts...we are a part of that as well." It will perhaps be in working through the spaces of this community and in working with people from other subordinated communities that we will be able to examine the ways in which we variously experience and enact systems of domination from dominant and subordinate subject positions. 


\section{Where Are You From?: Imagining an Alternate Citizenship}

In her critique of the normalization of the process called "assimilation," Yoshiko suggested that the term actually disguises what is an inherently racist imperative. She states, “I know people say it's not racism, but to me it is. It's the arrogance of one particular culture or group of people over another." 48 "There are so many different cultures or ethnic groups in Canada," she states, "You come out of it without really a claim to any...particular group or specific culture. You're this individual person."49 Yoshiko's analysis offers us a way of reconceptualizing the making of Canadian citizens: acknowledging the racism of the assimilation discourse and how such a process serves to pathologize "other" cultures and communities, in the service of producing an autonomous, "individual" citizen.

Irene's self-identification is questioned by white people in two ways. One: "Why doesn't she call herself a "Canadian'?" and two: when she does call herself "Canadian," the insistence that she must be "from" somewhere else and must disclose this to the interrogator. ${ }^{50}$ This second form of interrogation began when she was very young. She recalled an incident where she was wearing a kimono at Expo '67 in Montreal and a woman approached her and said, "Oh, aren't you cute. What are you?.... Are you Korean? Are you Chinese? Are you from Taiwan?" Irene's response: "No, no, no." as she thought, "What a stupid woman." "5t From an early age, Irene felt her resistance to interrogators seeking the originary through their racializing questions would be expressed by her response, "I am Canadian." Yet her interrogators would predictably not accept this response and would "go back far enough in the family history to find out" the where. "That turned me off saying 'I'm Canadian!'... But I'm not Japanese. That's not what I am. I'm Japanese Canadian," she concludes. ${ }^{52}$

Naomi, however, states that calling herself "Japanese Canadian" makes her uncomfortable. "It doesn't feel as real or natural... as saying...Sansei or Asian or Mixed." 53 For Naomi, Canada or Canadian does not "reflect" who she is. Rather these words - Canadian, American, Western - convey to her the notions of "consumption... exploitation...monoculture." 54

In the mnemonic encounters with people who imagine the nation as white, Asian women are continually assailed with questions as to our "other" origins. We are 
continually imagined as outside of the Canadian nation. The struggle for Japanese Canadian women is not so much to find the right words to describe ourselves but how we mobilize our understanding of why these identifiers are so important to others. Why is the adjectival originary (its use, non-use) or our use of "Canadian" so important to white Canadians? The term "Japanese Canadian" has always been mobilized in multiple ways. It has also been rejected or not used. Some of the women I interviewed used the term "Japanese" as a self-identifier or identifier of community members. It is, in fact, my selfidentification as "Japanese Canadian" that has taken discursive precedence throughout this thesis.

The term Sansei is also mobilized in different ways. Irene states she only uses the term when she is with Japanese Canadians/Americans. Sylvia also describes how she identified with the term "Sansei” but felt most people in her community wouldn't understand what that meant. "And you get tired of explaining things," she added. 55 Although I have been critical in this thesis of the ways in which the generational designations of "Issei," "Nisei," "Sansei" have been used to produce toializing images of each generation, I do see the use of these terms as a technology of memory. When used to situate ourselves in relation to the Internment, these terms serve as a way of identifying ourselves in relation to community and nation. They are also an enunciated resistance to the violence of demonizing our historical connections to the Japanese language.

Nevertheless, it is not the term "Japanese Canadian" or "Sansei" that are of uppermost interest to me here but how the linguistic obsession of white people with our naming or their naming is actually about how they are the point of contention within a nation of our imagining. As Laura Kang reminds us, in the demarcation of Asian women as outside of nation, the delineation of national identity is in effect contingent upon an identity identified as Asian. In this way, Asian women "calibrate...the membership criteria of the nation-state." ${ }^{56}$ Our memories of the Internment and our historical relationships to nation can be mobilized in this calibration of citizenship. And if the gates of belonging are only open to those who enter by means of dominating others, then perhaps we need to redefine citizenship and not the language we use to denote our citizenship. 


\section{Resisting the Liberal Autonomous Subject and Re-Viewing Subjects Who Resist}

All the women interviewed who were incarcerated invoked the memory of their parent(s) and were able to situate themselves relationally to them in comparing their own losses. Many reported their parents' and older siblings' losses as greater. All of them talked about the Internment within a memory of community and in reconstructing their memories of the violence, they reconstruct themselves as connected to others. Their mnemonic record of relationships honoured and valued stand against the violence that strove to destroy our communities. Through the handing down of this knowledge of the Internment, we have seen how daughters learn from multiple memory sources, embodiments of community and relationship, that both convey and reconfigure their own subjectivities relationally in struggling with the meanings of this history. It is this memory of a community connected through oppression and a memory resisting forgetting that shows us how we might struggle against constructing ourselves as autonomous from the struggles of others.

Evelyn reminds us how the knowledges produced through the Internment are knowledges one can mobilize and teach to others. While Japanese Canadians have often been denoted as "silent" about the Internment, there are multiple ways in which their knowledge of the violence are applied to understandings of other enactments of social domination. Evelyn explains that because she has been affected by this history, her "attitude to the society would be affected." 57 She states, she will not tolerate injustice or discrimination and her children will be affected by witnessing the stands that she takes.

All of the women interviewed have been active in community-related organizing. The ways in which women and men have built communities, including Japanese Canadian communities, are examples of resistance and must not be forgotten.

Eiko articulates how her philosophy of living was "passed down" from greatgrandmother to Grandma to aunt and mother to her: "Grandma and I called it recycled courage." 58 She sees her own involvement in social justice issues as reflective of what her parents have done with their knowledge of the Internment. The night I interviewed her they were volunteering for a social agency. "[My] involvement in social justice...comes 
as a direct result of an experience that's not even mine to claim, that sort of by osmosis is mine." 59 She adds:

I also think that in terms of very basic human rights, just to be on the side of the disabled, to be on the side of women, I know that's all shaped in me, wheelchair or not, woman or not, to fight for people of colour who live in situations of racism and and....60

Eiko attributes part of her own learning about who she is to the handing down of knowledge from her family and she concretized these connections in a poem written about her grandmother and grandfather. The poem, which was published, was also translated into Japanese by a friend and written on a "huge piece of rice paper" and framed. The translation of the poem in English is written on the back. "It's also a lovely piece of art work...at some point it will be a nice heirloom to hand down," she concludes. ${ }^{61}$ In the face of the dispossession of our families and the destruction of our communities, women have found different ways of handing down a knowledge of our interconnectedness.

Yuko emphasizes the connections between space and social constructions of subjectivity in her comment, there are "many factors that are involved in people's perception of their life. Being Japanese is one of them. But being a woman is another. Where you grew up is another." 62 She adds, "It's hard to separate because it's all one, being a Japanese Canadian woman. " 63 Yuko participated in the development of antidiscrimination policies in her workplace. For her, it is important to underline the heterogeneity of Japanese Canadians and challenge homogenizing practices when she works on projects committed to social change: "I don't represent all Japanese Canadian women. I try...to not have people [make] a generalization about all Japanese Canadians are like this or all Japanese Canadian women are like this." 64

Midori also argues against the homogeneous construction of "Japanese Canadians." Referring to the Japanese Canadian communities in Vancouver, she said, "it's not something that you can generalize." 65 She points out how the Vancouver communities are made up of members who have lived in Canada for many generations and others who have immigrated to Canada more recently and in the post-Internment period: "Trying to classify that as a unified group is pretty difficult." 
Sylvia wanted to underline her middle-class social location and how she feels she has some options that working-class people of colour do not have in dealing with the racism they experience. ${ }^{67}$ Her comment suggests how race, class, gender, sexuality, and physical/mental ability interlock and construct us as relational and hierarchized subjects even as Japanese Canadians and people of colour. But as the Internment demonstrated, a privileged class location did not protect middle-class people from being expelled from their homes.

A vision of the subject who comes to know the self in relation to others and as sharing a history with others was offered by Janice. She describes how being Japanese Canadian for her is not about how one looks. She plans to have children with her white male partner and feels they "won't look Asian at all."68 But she knows, "They're going to identify with being JC." ${ }^{69}$ She thinks about how they might be questioned about this identification but it is clear to her that subjectivity is about how you understand yourself in relation to your familial and communal history:

How I perceive myself to be Japanese Canadian isn't how I look because that isn't my defining thing to the outside world. It's... your values, how you treat your family, your relationships with people. I know for my kids too that's what their cultural identity is going to be. It's not going to be [from] taking odori and learning to do flower arranging.... It's going to be the fact that they know who all their cousins are. They'll know about their aunts and uncles. They'll know about their grandparents and they'll know everything that's happened to our family. The idea of people identifying with who they are is knowing who you actually are. ${ }^{70}$

Sylvia also wonders how her daughter will be constructed by others but is clear how she wants her to see herself. She remembers how when she was a child racist and sexist constructions of Japanese Canadian women produced the feeling that she did not look "right" because she "didn't look white."71 When she thinks about her child, she states, "She doesn't look all that Japanese"72 but "I don't want her to think that she's white." 73 She adds, "I want her to be aware of her ancestry and I want her to socialize with other Japanese Canadians" 74 and concludes, "I want her to be very aware of who she is." 75

While this conclusion focuses upon how women remember and struggle against violence, the images of struggle we imagine for ourselves also entail a re-imagining of the 
male subject. In this project, I was not able to analyze the ways in which men reconstruct their memories of the Internment or how these memories are handed down to sons of families who were incarcerated. Yoshiko expressed this limitation of my work well when she stated, "I really feel badly that more men and young men are not part of the discussion or not part of the discourse of making a whole picture."76 Yoshiko's implicit critique of my methodology was well-taken and I agree that work needs to be done that critically examines the position of Japanese Canadian boys and men in relation to the Internment and the nation. More critical work must also be developed in understanding the relationship of our non-Japanese Canadian family and community members to our Internment histories. How do they struggle with hegemonic notions of the subject given their different social locations and their mnemonic encounters with our memories of the Internment and our daily experiences as racialized women?

In acknowledging attempts by Sansei and Yonsei to represent the Internment, May also impressed upon me that she "resent[s] third and fourth generation persons writing about [her] experience and saying we were like slaves." 77 Her comment indicates the need to reconstitute herself in opposition to what she sees as the fixity of some representational images and she concludes "what happened was completely contrary to what the bigoted politicians aimed for when they moved us out. In the larger picture, they certainly didn't get rid of us or put us down." ${ }^{\text {78 }}$ I feel that it is necessary to underline that the Internment was a violent process and there have been those who have described their treatment as a form of slavery. ${ }^{79}$ Yet I take May's comments as a challenge to understand the impact of our representational work upon survivors and as I have argued in this thesis, we must begin by examining our own subject positions in relation to our efforts to remember. Within her expression of protest against objectifying portrayals of Japanese Canadians, May is also clear on what the government's aims were - to "get rid of us" and "put us down." She expands on these comments by emphasizing how she was separated from all of her Vancouver friends and felt that others who were incarcerated "seemed to have a friend" while she had to start at "square one... That felt really unfair somehow, that everybody else had a community." 80 This isolation resulted in what May calls a "disorientation," going "back and forth," "not being anywhere," and she links her feeling 
of disorientation to the crossing of boundaries between Japanese Canadian spaces and non-Japanese Canadian spaces. ${ }^{81}$

As Japanese Canadian women who have lived through and inherited the history of Internment, we negotiate the relations of power in our lives and confront the "orienting" of our selves - the images of racialized, sexualized Asian women - that situate us as gendered and raced subjects outside of the Canadian nation. Each of us develops various strategies for resisting these disorienting processes and the systems of domination that produce them.

It is to be hoped that we can widen our understanding of resistance in our commemorative practices to include more complex notions of how women. men, and children struggled to survive the violence of incarceration and how we continue to struggle in a country where our spaces of existence and non-existence were mapped out through national violence. Remembering that people struggled in each of the carceral spaces and subsequently in the spaces to which we were dispersed, and that the very act of remembering these spaces and the people who struggled within them can be an act of resisting violence, may lead us to a different notion of the Canadian nation - one where people struggle against domination. Remembering our "embodiment, relationality, difference ${ }^{182}$ through our history of Internment and other struggles against oppression in this country may offer us and subsequent generations support for imagining and enacting resistance. The memories we inherit and hand across of the Internment offer us possibilities for unsettling the hegemonic notions of nation, citizenship, and the subject. "Disidentification"83 with these hegemonies may be a starting point for re-imagining ourselves, our communities, and new forms of political engagement.

\section{Endnotes: Conclusion}

1. Lisa Lowe, Immigrant Acts, p. 170.

2. Murray, "Silence No More."

3. Interview with Kazuko, p.74.

4. McAllister, "Cultural Production," p.174.

5. Interview with Evelyn, p.114. 
6. Ibid., p.112.

7. Ibid.

8. Interview with Margaret, p.80.

9. Ibid., p.80.

10. Interview with Kazuko, p.58.

11. Ibid.

12. Ibid., p.58.

13. Ibid.

14. Ibid., p. 74.

15. Interview with Sylvia, p.22.

16. Ibid., p.23.

17. Interview with Midori, p.67.

18. Interview with Louise, p.77.

19. Interview with Haru, p.91.

20. Ibid., p.87.

21. Interview with Ann, p.79.

22. Mayumi quoted in interview with Ann, p.92.

23. Interview with Mayumi, p.26.

24. Ibid.

25. Interview with Eiko, p.51.

26. Ibid.

27. Interview with Kyo, p.71.

28. Interview with Yuko, p.21.

29. Interview with May, pp.76-77, emphasis in the original.

30. Ibid., p.77. 
31. Interview with S., p.49.

32. Ibid., p.50.

33. Ibid., p.54.

34. Ibid.

35. Ibid., p.58.

36. Interview with Aya, p.63.

37. Interview with Sylvia, p.68.

38. Ibid., p.63.

39. Ibid.

40. Interview with Esther, p.88.

41. Interview with Joanne, p.76.

42. Ibid.

43. Interview with May, p.67.

44. McAllister, “Cultural Production,” p.66.

45. Interview with May, p.9.

46. Ibid.

47. Interview with Naomi, p.37.

48. Interview with Yoshiko, p.58.

49. Ibid., p.59.

50. Interview with Irene, p.51.

51. Ibid., p.51.

52. Ibid.

53. Interview with Naomi, p.64.

54. Ibid., p.65.

55. Interview with Sylvia, p.47. 
56. Kang, “Compositional Subjects," p.134.

57. Interview with Evelyn, p.93.

58. Interview with Eiko, p.35.

59. Ibid., p.33.

60. Ibid., p.51.

61. Ibid, p.3.

62. Interview with Yuko, p.25.

63. Ibid., p.38.

64. Ibid., pp.39-40, emphasis in the original.

65. Interview with Midori, p.107.

66. Ibid.

67. Interview with Sylvia, p.59.

68. Interview with Janice, p.58.

69. Ibid.

70. Ibid.

71. Interview with Sylvia, p.60.

72. Ibid, p.58.

73. Ibid, p.64.

74. Ibid, p.47.

75. Ibid., p.65.

76. Interview with Yoshiko, p.98.

77. Interview with May, p.79.

78. Ibid.

79. See for example, Elmer Oike's statement that when Japanese Canadians arrived in Manitoba, farmers picked the workers "like slaves in the old slave markets." Oike quoted in The History of Japanese Canadians in Manitoba, p.19. 
80. Interview with May, p.80.

81. Ibid.

82. Yeğenoğlu, Colonial Fantasies, p.8.

83. Lowe, Immigrant Acts, p. 103. 


\section{BIBLIOGRAPHY}

Adachi, Ken. The Enemy That Never Was: A History of the Japanese Canadians. Toronto: McClelland and Stewart, 1979.

-. The Enemy That Never Was: A History of the Japanese Canadians. Toronto: McClelland and Stewart, 1991.

Adachi, Pat. Asahi: A Legend in Baseball. Etobicoke, ON: 1992.

Ahmad, Aijaz. In Theory: Classes, Nations, Literatures. London and New York: Verso, 1992.

Alarcón, Norma. "The Theoretical Subject(s) of This Bridge Called My Back and AngloAmerican Feminism." In Making Face, Making Soul: Creative and Critical Perspectives by Women of Color, edited by Gloria Anzaldúa, pp.356-369. San Francisco: Aunt Lute Foundation, 1990.

Alonso, Ana Maria. "The Politics of Space. Time and Substance: State Formation, Nationalism and Ethnicity." Annual Review of Anthropology 23 (1994): 379-405.

Anderson, Benedict. Imagined Communities. London and New York: Verso, 1991.

Anderson, Kay. Vancouver's Chinatown. Montreal and Kingston: McGill Queen's University Press, 1991.

Angus, H.F. Preface to The Canadian Japanese and World War II, by Forrest E. La Violette, i-vi. Toronto: University of Toronto Press, 1948.

Antze, Paul and Michael Lambek, eds. Tense Past: Cultural Essays in Trauma and Memory. New York and London: Routledge, 1996.

Armor, John, and Peter Wright. Manzanar. New York: Random House, Vintage Books, 1989.

Ashworth, Mary. The Forces Which Shaped Them. Vancouver: New Star Books, 1979.

Axford, Roger W. Too Long Silent: Japanese Americans Speak Out Lincoln, Nebraska: Media Publishing and Marketing, Inc., 1986.

Ayukawa, Midge. “Good Wives and Wise Mothers: Japanese Picture Brides in Early Twentieth-Century British Columbia." B.C. Studies, 105-106 (Spring 1995): 103 118.

Bakan, Abigail B., and Daiva Stasiulis. Introduction to Not One of the Family, edited by Abigail B. Bakan and Daiva Stasiulis, pp.3-27. Toronto: University of Toronto Press, 1997.

Bar-On, Dan. Fear and Hope: Three Generations of the Holocaust. Cambridge and London: Harvard University Press, 1995.

Benjamin, Walter. Iluminations, edited by Hannah Arendt. New York: Harcourt, Brace and World, 1968.

Bergmann, Martin S. and Milton E. Jucovy. Preface to Generations of the Holocaust, edited by Bergmann and Jucovy, pp.3-29. New York: Columbia University Press, 1990.

Berlant, Lauren. The Anatomy of National Fantasy. Chicago and London: University of Chicago Press, 1991.

Berreman, Gerald D. "Aleut Reference Group Alienation, Mobility, and Acculturation." American Anthropologist 66,2 (1964): 231-250.

Bhabha, Homi K. The Location of Culture. London and New York: Routledge, 1994.

-. "The Other Question..." Screen 24, 6 (November-December 1983): 18-36. 
Boyarin, Jonathan. "Space, Time, and the Politics of Memory." In Remapping Memory, edited by Jonathan Boyarin, pp.1-37. Minneapolis and London: University of Minnesota Press, 1994.

-. Storm from Paradise. Minneapolis and London: University of Minnesota Press, 1992.

-, ed. Remapping Memory. Minneapolis and London: University of Minnesota Press, 1994.

Breen, David, and Kenneth Coates. Vancouver's Fair: An Administrative and Political History of the Pacific National Exhibition. Vancouver: University of British Columbia, 1982.

Broadfoot, Barry. Years of Sorrow, Years of Shame: The Story of Japanese Canadians in World War II. Toronto: Doubleday, 1977.

Bumet, Jean, and Howard Palmer. Introduction to The Enemy That Never Was: A History of the Japanese Canadians, by Ken Adachi. Toronto: McClelland and Stewart, 1976.

Burton, Antoinette. "Who Needs the Nation? Interrogating 'British' History." Joumal of Historical Sociology 10, 3 (September 1997): 227-248.

Butler, Judith. Bodies that Matter. New York and London: Routledge, 1993.

Caruth, Cathy. Unclaimed Experience: Trauma, Narrative, and History. Baltimore. Maryland: John Hopkins University Press, 1996.

-, ed. Trauma: Explorations in Memory. Baltimore and London: John Hopkins University Press, 199

Cha, Theresa Hak Kyung. Dictée. New York: Tanam Press, 1982.

Chan, Sucheng. Asian Americans: An Interpretive History. Boston: Twayne Publishers, 1991.

Cheung, King-Kok. Articulate Silences: Hisaye Yamamoto, Maxine Hong Kingston, Joy Kogawa. Ithaca and London: Comell University Press, 1993.

Chow, Rey. Writing Diaspora. Bloomington and Indianapolis: Indiana University Press. 1993.

Choy, Christine, and Renee Tajima (Directors). Who Killed Vincent Chin? New York:

Filmmakers Library, 1988. Film.

Choy, Wayson. The Jade Peony. Vancouver: Douglas \& McIntyre, 1996.

Chrystos. Dream On. Vancouver: Press Gang, 1991.

Chuh, Kandice. "Transnationalism and Its Past." Public Culture 9, (1996): 93-1 12.

Collins, Patricia Hill. Black Feminist Thought: Knowledge, Consciousness, and the Politics of Empowerment. New York and London: Routledge, 1991.

Cook-Lynn, Elizabeth. Why I Can't Read Wallace Stegner and Other Essays. Madison: University of Wisconsin Press, 1996.

Creef, Elena Tajima. "Re/Orientations: The Politics of Japanese American Representation." Ph.D. dissertation, University of California, Santa Cruz. 1994.

Danieli, Yael. "Treating Survivors and Children of Survivors of the Nazi Holocaust." In Post-Traumatic Therapy and Victims of Violence, edited by Frank M. Ochberg, pp.278-194. New York: Brunner/Mazel, 1988.

Daniels, Roger. Afterword to The Enemy That Never Was: A History of the Japanese Canadians, by Ken Adachi, pp.371-377. Toronto: McClelland and Stewart, 1979,

-. Concentration Camps: North America. Japanese in the United States and Canada During World War II. Malabar, FL: Robert E.Krieger, 1981. 
Daniels, Roger, ed. Two Monographs on Japanese Canadians. New York: Arno Press, 1978.

Daniels, Roger, et al., eds. Two Reports on Japanese Canadians in World War II. New York: Arno Press, 1978.

Davey, Frank. "The Land That Is Like Every Land." In Post-National Arguments, pp. 100112. Toronto: University of Toronto Press, 1993.

Delbo, Charlotte. None of Us Will Return. Translated by John Githens. New York: Grove Press, 1968.

De Angelis, Maria. "Testimonies: Internment, Racism and Injustice in Canada." In In Justice: Canada, Minorities, and Human Rights, edited by Roy Miki and Scott McFarlane, pp.23-26. Winnipeg: National Association of Japanese Canadians. 1996.

Di Matteo, Enzo. "Tories Slam Book On Anti-Racist Schooling." Now, 18, 7 (October $15-21,1998)$, p.24

Dower, John. War Without Mercy. New York: Pantheon Books, 1986.

Eng, David L. "Out Here and Over There: Queerness and Diaspora in Asian American Studies." Social Text 52/53, 15, 3/4 (Fall/Winter 1997): 29-50.

Essed, Philomena. Everyday Racism. Claremont, CA: Hunter House, 1990.

-. Understanding Everyday Racism. Newbury Park, CA: Sage Publications, 1991.

Fanon, Frantz. Black Skin. White Masks. Translated by Charles Lam Markmann. New York: Grove Press, 1967.

Farber, Michael. "Two Different Worlds." Sports Illustrated 88, 3 (January 26, 1998): 6669.

Feldman, Allen. Formations of Violence. Chicago and London: University of Chicago Press, 1991.

Fellows, Mary Louise and Sherene Razack. "The Race to Innocence: Confronting Hierarchical Relations Among Women," The Journal of Gender, Race and Justice 1, 2 (Spring 1998): 335-352.

Felman, Shoshana. "Education and Crisis, Or the Vicissitudes of Teaching." In Testimony: Crises of Witnessing in Literature, Psychoanalysis, and History, pp. 1 56. New York and London: Routledge, 1992.

-. "Forms of Judicial Blindness, or the Evidence of What Cannot Be Seen." Critical Inquiry 23, 4 (Summer 1997): 738-788.

Felman, Shoshana and Laut, Dori. Testimony: Crises of Witnessing in Literature, Psychoanalysis, and History. New York and London: Routledge, 1992.

Field, Norma. From My Grandmother's Bedside. Berkeley: University of California Press, 1997.

Figley, Charles R. Trauma and Its Wake: The Study of Post-Traumatic Stress Disorder. New York: Brunner/Mazel, 1985.

Foucault, Michel. "Confinement, Psychiatry, Prison: A Dialogue with Michel Foucault, David Cooper, Jean-Pierre Faye, Marie-Odile Faye and Marine Zecca." In Politics, Philosophy, Culture: Interviews and Other Writings, 1977-1984, edited with an Introduction by Lawrence D. Kritzman, pp. 178-210. New York and London: Routledge, 1990.

- Discipline and Punish: The Birth of the Prison, translated by Alan Sheridan. New York: Random House, Vintage Books, 1995. 
-. "Film and Popular Memory. An Interview with Michel Foucault." By Cahiers du Cinema. Radical Philosophy 11 (Summer 1975): 24-29.

- Language, Counter-Memory, Practice. Ithaca: Cornell University Press, 1977.

- The History of Sexuality. Volume 1, translated by Robert Hurley. New York: Random House, Vintage Books, 1990.

- Power/Knowledge: Selected Interviews and Other Writings, 1972-1977. New York:

Pantheon, 1980.

-. "The Subject and Power." Critical Inquiry 8 (1982): 208-226.

Fry, Joseph. “Omoide Garden. Neys, Ontario." Unpublished manuscript, n.d.

Fukushima, Michael (Director). Minoru: Memory of Exile. Montreal: National Film Board of Canada, 1992. Film.

Gilroy, Paul. 'There Ain't No Black in the Union Jack': The Cultural Politics of Race and Nation. London: Century Hutchinson, 1987.

Glenn, Evelyn Nakano. Issei, Nisei, War Bride: Three Generations of Japanese American

Women in Domestic Service. Philadelphia: Temple University Press, 1986.

Gluck, Sherna Berger, and Daphne Patai, eds. Women's Words: The Feminist Practice of Oral History. New York and London: Routledge, 1991.

Goldberg, David Theo. Racist Culture. Oxford and Cambridge: Blackwell, 1993.

Goto, Hiromi. Chorus of Mushrooms. Edmonton: NeWest Press, 1994.

Granatstein, J.L., and Gregory A. Johnson. "The Evacuation of the Japanese Canadians,

1942: A Realist Critique of the Received Version." In On Guard for Thee: War,

Ethnicity, and the Canadian State, 1939-1945, edited by Norman Hillmer, Bohdan

Kordan and Lubomyr Luciuk, pp.101-129. Ottawa: Minister of Supply and

Services Canada, 1988.

Grewal, Inderpal, and Caren Kaplan. "Introduction: Transnational Feminist Practices and

Questions of Postmodernity." In Scattered Hegemonies: Postmodernity and

Transnational Feminist Practices, edited by Inderpal Grewal and Caren Kaplan,

pp. 1-33. Minneapolis: University of Minnesota Press, 1994.

Grewal, Inderpal, and Caren Kaplan, eds. Scattered Hegemonies: Postmodernity and

Transnational Feminist Practices. Minneapolis and London: University of

Minnesota Press, 1994.

Hale, Janet Campbell. Bloodlines. New York: HarperCollins, 1993.

Hanna, Deirdre. “Andrew Danson's Face Kao Shows Canada's Lack of Honour.” Now

15, 29 (March 21-27, 1996), p.60.

Hass, Aaron. In the Shadow of the Holocaust. Ithaca and London: Comell University Press, 1990.

Henriques, Julian, Wendy Hollway, Cathy Urwin, Couze Venn, and Valerie Walkerdine.

Changing the Subject: Psychology, Social Regulation and Subjectivity. London and New York: Methuen, 1984.

Herman, Judith Lewis. Trauma and Recovery. New York: Basic Books, 1992.

Hirabayashi, Gordon. Review of This Is My Own: Letters to Wes and Other Writings on Japanese Canadians, 1941-1948, by Muriel Kitagawa, edited by Roy Miki.

Canadian Ethnic Studies 21, 3 (1989): 139-141.

Hoffman, Linda Uyehara. "A Long Strange Trip It's Been." In Bringing It Home, pp. 184198. Edited by Brenda Lea Brown. Vancouver: Arsenal Pulp Press, 1996. 
hooks, bell. "Feminism: A Transformational Politic." In Talking Back: Thinking

Feminist, Thinking Black, pp.19-27. Boston: South End Press, 1989.

Houston, Jeanne Wakatsuki, and James D. Houston. Farewell to Manzanar. Boston:

Houghton Mifflin, 1973.

lacovetta, Franca. Such Hardworking People: Italian Immigrants in Postwar Toronto.

Montreal and Kingston: McGill-Queen's University Press, 1992.

Ibuki, Norm. "Nikkei Centre, Breaking the Silence." The Bulletin 36, 7 (July 1994): 1315.

Ichioka, Yuji. "The Meaning of Loyalty: The Case of Kazumaro Buddy Uno." Amerasia Joumal 23, 3 (1997): 45-71.

-, ed. Views from Within: The Japanese American Evacuation and Resettlement Study. Los Angeles: Asian American Studies Center, University of California, Los Angeles, 1989.

Irons, Peter. Justice at War: The Story of the Japanese American Internment Cases. New York and Oxford: Oxford University Press, 1983.

-, ed. Justice Delayed: The Record of the Japanese American Internment Cases. Middleton, CT: Wesleyan University Press, 1989.

Ito, Roy. Stories of My People. Hamilton, ON: S-20 and Nisei Veterans Association. 1994.

- We Went to War: The Story of the Japanese Canadians Who Served During the First and Second World Wars. Stittsville, ON: Canada's Wings, Inc., 1984.

Japanese Canadian Centennial Project. A Dream of Riches. Vancouver: The Japanese Canadian Centennial Project, 1978.

Kadi, Joanna. Thinking Class. Boston: South End Press, 1996.

Kanbara, Bryce, ed. Shikata Ga Nai. Hamilton, ON: Hamilton Artists' Inc., 1989. Art Exhibition Catalogue.

Kang, Laura Hyun Yi. “Compositional Subjects: Enfiguring Asian/American Women.”

Ph.D. dissertation, University of California, Santa Cruz, June 1995.

Kawano, Roland M. Ministry to the Hopelessly Hopeless. Scarborough, ON: The Japanese Canadian Christian Churches Historical Project, 1997.

Kenna, Kathleen. "Land of the Free?" Toronto Star, 12 July 1998, p.E5.

Kim, Elaine and Norma Alarcón, eds. Writing Self, Writing Nation. Berkeley, CA: Third Woman Press, 1994.

Kitagawa, Muriel. This is My Own: Letters to Wes \& Other Writings on Japanese

Canadians, 1941-1948, edited by Roy Miki. Vancouver: Talonbooks. 1985.

Kitano, Harry H.L. Japanese Americans: The Evolution of a Subculture. 2d ed. Englewood Cliffs, NJ: Prentice Hall, 1969.

Kiyooka, Roy. Mothertalk: Life Stories of Mary Kiyoshi Kiyooka, edited by Daphne Marlatt. Edmonton, AB: NeWest, 1997.

-. Pacific Windows: Collected Poems of Roy K. Kiyooka, edited by Roy Miki. Burnaby, BC: Talonbooks, 1997.

Knight, Rolf, and Maya Koizumi. A Man of Our Times: The Life-History of a JapaneseCanadian Fisherman. Vancouver: New Star Books, 1976.

Kobayashi, Addie. Exiles in Our Own Country: Japanese Canadians in Niagara.

Richmond Hill, ON: Nikkei Network of Niagara, 1998. 
Kobayashi, Audrey. "Coloring the Field: Gender, 'Race,' and the Politics of Fieldwork." Professional Geographer, 46,1 (February 1994): 73-80.

-. "A Demographic Profile of Japanese Canadians and Social Implications for the Future." Canada: Department of the Secretary of State, September 1989. Mimeograph.

-. "Emigration from Kadeima, Japan, 1885-1950: An Analysis of Community and Landscape Change." Ph.D. dissertation, UCLA, 1984.

-. "For the Sake of the Children: Japanese/Canadian Workers/Mothers." In Women, Work, and Place, edited by Audrey Kobayashi, pp.45-72.. Montreal and Kingston: McGill-Queen's University Press, 1994.

-. "The Historical Context for Japanese-Canadian Uprooting." In Social Change and Space, edited by Ludger Muller-Wille, pp.69-82. Montreal: McGill University, 1989.

- Memories of Our Past: A Brief Walking Tour of Powell Street. Vancouver: NRC Publishing, 1992.

-. "The Uprooting of Japanese Canadians After 1941." Tribune Juive, 5, 1 (Juillet-Août 1987): 28-35.

- Review of Mutual Hostages: Canadians and Japanese during the Second World War. by Patricia Roy, J.L. Granatstein, Masako lino, and Hiroko Takamura. B.C. Studies 96 (Winter 1992-1993): 117-121.

Kogawa, Joy. Itsuka. Toronto: Penguin Books, 1992.

- Obasan. Toronto: Lester \& Orpen Dennys, 1981; Toronto: Penguin Books, 1983. LaCapra, Dominick. Representing the Holocaust: History, Theory, Trauma. Ithaca and London: Comell University Press, 1994.

Lang, Catherine. O-Bon in Chimunesu. Vancouver: Arsenal Pulp Press, 1996.

Langer, Lawrence L. Admitting the Holocaust. New York and Oxford: Oxford University Press, 1995.

- Holocaust Testimonies: The Ruins of Memory. New Haven and London: Yale University, 1991.

Laub, Dori. "Bearing Witness or the Vicissitudes of Listening." In Testimony: Crises of Witnessing in Literature, Psychoanalysis, and History, by Shoshana Felman and Dori Laub, pp.57-74. New York and London: Routledge, 1992.

La Violette, Forrest E. The Canadian Japanese and World War II. Toronto: University of Toronto Press, 1948.

Lifton, Robert Jay. The Broken Connection: On Death and the Continuity of Life. New York: Simon and Schuster, 1979.

Lim, Shirley Geok-Lin. “Japanese American Women's Life Stories: Maternality in Monica Sone's Nisei Daughter and Joy Kogawa's Obasan. Feminist Studies 16, 2 (Summer 1990): 289-312.

Linden, R. Ruth. Making Stories, Making Selves. Columbus, OH: Ohio State University Press, 1993.

Liu, Lydia. "The Female Body and Nationalist Discourse: The Field of Life and Death Revisited." In Scattered Hegemonies: Postmodernity and Transnational Feminist Practices, edited by Inderpal Grewal and Caren Kaplan, pp.37-62. . Minneapolis and London: University of Minnesota Press, 1994. 
Loo, Chalsa M. “An Integrative-Sequential Treatment Model for Posttraumatic Stress Disorder: A Case Study of the Japanese American Internment and Redress." Clinical Psychology Review, 13, 2 (1993): 89-117.

Lorde, Audre. Sister Outsider. New York: The Crossing Press, 1984.

Lowe, Lisa. Critical Terrains. Ithaca and London: Cornell University Press, 1991.

- Immigrant Acts. Durham and London: Duke University Press, 1996.

Lustiger-Thaler, Henri. "Remembering Forgetfully." In Re-Situating Identities, edited by Vered Amit-Talai and Caroline Knowles, pp.190-217. Peterborough, ON: Broadview Press, 1996.

Maclear, Kyo. Beclouded Visions: Hiroshima-Nagasaki and the Art of Witness. Albany, NY: State University of New York Press, 1999.

—. "Beclouded Visions: Hiroshima-Nagasaki and the Art of Witness." Masters thesis. University of Toronto, 1996.

-. "The Myth of the "Model Minority." Re-thinking the Education of Asian Canadians." Our Schools/Our Selves 5, 3 (July 1994): 54-76.

-. "Not in So Many Words: Translating Silence Across 'Difference." Fireweed 44/45 (Summer 1994): 6-11.

Makabe, Tomoko. The Canadian Sansei. Toronto: University of Toronto Press, 1998.

-. "Ethnic Group Identity: Canadian-Born Japanese in Metropolitan Toronto." Ph.D. dissertation, University of Toronto, 1976.

-. Picture Brides: Japanese Women in Canada. Translated by Kathleen Chisato Merken. Toronto: Multicultural History Society of Ontario, 1995.

-. Shashinkon no Tsumatachi. Tokyo: Mirai-sha, 1983.

Malkki, Lisa. "National Geographic: The Rooting of Peoples and the Territorialization of National Identity Among Scholars and Refugees." Cultural Anthropology 7, 1 (February 1992): 24-44.

Manitoba Japanese Canadian Citizens' Association. The History of Japanese Canadians in Manitoba. Winnipeg: Manitoba Japanese Canadian Citizens’ Association, 1996.

Marks, Laura U. “A Deleuzian Politics of Hybrid Cinema." Screen 35, 3 (Autumn 1994): 244-264.

Mass, Amy Iwasaki. "Psychological Effects of the Camps on Japanese Americans." In Japanese Americans: From Relocation to Redress, edited by Roger Daniels, Sandra C. Taylor, and Harry H.L. Kitano, pp.159-162.. Seattle and London: University of Washington Press, 1991.

Matsuda, Mari, Charles R. Lawrence III, Richard Delgado, and Kimberlè Williams Crenshaw, eds. Words That Wound. Boulder, CO: Westview Press, 1993.

Matsumoto, Valerie J. Farming the Home Place: A Japanese American Community in California, 1919-1982. Ithaca and London: Cornell University Press, 1993.

-. "Japanese American Women During World War II." In Unequal Sisters: A MultiCultural Reader in U.S. Women's History, edited by Ellen Carol DuBois and Vicki L. Ruiz, pp.373-386. New York and London: Routledge, 1990.

-. "Reflections on Oral History: Research in a Japanese American Community." In Feminist Dilemmas in Fieldwork, edited by Diane L. Wolf, pp.160-169. Boulder, CO: Westview Press, 1996.

McAllister, Kirsten Emiko. “Asians in Hollywood.” Cineaction 30 (1992): 8-13. 
-. "Confronting Official History With Our Own Eyes: Video-Documentary in the Japanese Canadian Community." West Coast Line 13/14 (Spring-Fall 1994): 6684.

-. "Cultural Production and Alternative Political Practices: Dialogic Cultural Forms and the Public Sphere in the Japanese Canadian Community." Master's thesis, Simon Fraser University, August 1993.

McAllister, Kirsten, and Scott McFarlane. "Documentary Perpetuates Myth of the Passive Japanese Canadian." The Bulletin (December 1992): 25.

McCann, I. Lisa, and Laurie Anne Pearlman. "Vicarious Traumatization: A Framework for Understanding the Psychological Effects of Working with Victims." Journal of Traumatic Stress 3, 1 (1990): 131-149.

McClintock, Anne. Imperial Leather. New York and London:

McClintock, Anne, Aamir Mufti, and Ella Shohat, eds. Dangerous Liaisons. Minneapolis and London: University of Minnesota Press, 1997.

McFarlane, Scott. "Covering Obasan and the Narrative of Internment." In Privileging Positions: The Sites of Asian American Studies, edited by Gary Y. Okihiro, Marilyn Alquizola, Dorothy Fujita Rony, and K. Scott Wong, pp.401-411. Pullman, WA: Washington State Press, 1995.

Miki, Roy. "Asiancy: Making Space for Asian Canadian Writing." In Privileging Positions: The Sites of Asian American Studies, edited by Gary Y. Okihiro. Marilyn Alquizola, Dorothy Fujita Rony, and K.Scott Wong, pp.135-151. Pullman, WA: Washington State Press, 1995.

-. Broken Entries: Race, Subiectivity, Writing. Toronto: Mercury Press, 1998.

-. "Introduction: The Life and Times of Muriel Kitagawa." In This is My Own: Letters to Wes \& Other Writings on Japanese Canadians, by Muriel Kitagawa, edited by Roy Miki, pp.1-64. Vancouver: Talonbooks, 1985.

-. Random Access File. Red Deer, AB: Red Deer College Press, 1995.

-. Saving Face. Winnipeg: Turnstone Press, 1991.

Miki, Roy, and Cassandra Kobayashi. Justice in Our Time: The Japanese Canadian

Redress Settlement. Vancouver: Talonbooks; Winnipeg: National Association of Japanese Canadians, 1991.

Miki, Roy, and Scott McFarlane, eds. In Justice: Canada. Minorities, and Human Rights. Winnipeg: National Association of Japanese Canadians, 1996.

Miller, J.R. Shingwauk's Vision: A History of Native Residential Schools. Toronto: University of Toronto Press, 1996.

Mirikitani, Janice. Shedding Silence. Berkeley: Celestial Arts, 1987.

Mohanty, Chandra Talpade. "Under Western Eyes: Feminist Scholarship and Colonial Discourses." Third World Women and the Politics of Feminism, edited by Chandra Talpade Mohanty, Ann Russo and Lourdes Torres, pp.5 I-80. Bloomington and Indianapolis: Indiana University Press, 1991.

Monture-Angus, Patricia. Thunder in My Soul. Halifax: Fernwood, 1996.

Moritsugu, Frank. "In 1976, some stores refused to sell Michi's book." Nikkei Voice, 13, 4 (May 1999), p.5.

Morrison, Toni. "The Site of Memory." In Out There: Marginalization and Contemporary Cultures, edited by Russell Ferguson, Martha Gever, Trinh T. Minh-ha, and Cornel 
West, pp.299-305. New York: The New Museum of Contemporary Art and Cambridge, MA: The MIT Press, 1990.

-. "Unspeakable Things Unspoken: The Afro-American Presence in American

Literature." Michigan Quarterly Review 28, 1 (Winter 1989): 1-34.

Mufti, Aamir, and Ella Shohat. Introduction to Dangerous Liaisons, edited by Anne McClintock, Aamir Mufti, and Ella Shohat, pp.1-12. Minneapolis and London:

University of Minnesota Press, 1997.

Mura, David. Where the Body Meets Memory. New York: Doubleday, 1996.

Murray, Alice Yang. “' Silence, No More': The Japanese American Redress Movement, 1942-1992." Ph.D. dissertation, Stanford University, December 1994.

Nagata, Donna K. "The Japanese-American Internment: Perceptions of Moral Community,

Fairness, and Redress." Journal of Social Issues, 46, 1 (1990): 133-146.

- Legacy of Injustice: Exploring the Cross-Generational Impact of the Japanese

American Liternment. New York and London: Plenum Press, 1993.

Nakada, Mark Tadao. Ryukyu Rheology. Calgary: disOrientation Chapbooks, 1997.

Nakahara, Yoko Urata. "Ethnic Identity Among Japanese Canadians in Edmonton: The

Case of Pre-World War II Immigrants and Their Descendents." Ph.D. dissertation,

University of Alberta, Spring 1991.

Nakanishi, Don T. "Surviving Democracy's 'Mistake': Japanese Americans and the

Enduring Legacy of Executive Order 9066." Amerasia Journal 19, 1 (1993): 7-35.

Nakano, Mei. Japanese American Women. Berkeley and Sebastopol, CA: Mina Press and

San Francisco: National Japanese American Historical Society, 1990.

Nakano, Takeo Ujo, with Leatrice Nakano. Within the Barbed Wire Fence. Toronto:

University of Toronto Press, 1980.

Nakayama, Gordon G. Issei: Stories of Japanese Canadian Pioneers. Toronto: NC Press. 1984.

National Association of Japanese Canadians. The Case for Redress. Toronto: National Association for Japanese Canadians, n.d.

National Association of Japanese Canadians. Economic Losses of Japanese Canadians After 1941. Winnipeg: National Association of Japanese Canadians, 1985.

"Nikkei Internment Memorial Centre opening in New Denver." The Bulletin 36, 8 (August 1994): 17.

Nishi, Susan. "The Neighbourhood and Local Heroes." Powell Street Festival 5,1

(February 1999), n.p.

Nishiguchi, Gabrielle. "'Reducing the Numbers': The 'Transportation' of the Canadian Japanese (1941-1947). Masters thesis, Carleton University, 1993.

Nora, Pierre. "Between Memory and History: Les Lieux de Mémoire." Representations 26 (Spring 1989): 7-25.

Nunoda, Peter. "A Community in Transition and Conflict: The Japanese Canadians, 19351951." Ph.D. dissertation, University of Manitoba, 1991.

Ochberg, Frank M., ed. Post-Traumatic Therapy and Victims of Violence. New York: Brunner/Mazel, 1988.

Ohama, Baco. Red Poems of Rain and Voice. Montreal: 1995.

- Chiraishi. Stories from the Garden. Vancouver: n.d.

Ohama, Linda (Director). The Last Harvest. Vancouver: Harvest Productions, 1993. Film. 
Oikawa, Mona. “'Driven to Scatter Far and Wide': The Forced Resettlement of Japanese Canadians to Southem Ontario, 1944-1949." Master's thesis, University of Toronto, 1986.

-. "For Shizu." Fireweed 28 (Spring 1989): 19.

Oiwa, Keibo. Stone Voices: Wartime Writings of Japanese Canadian Issei. Montreal:

Vehicule Press, 1991.

Okamura, Raymond Y. "The American Concentration Camps: A Cover-Up Through Euphemistic Terminology." The Journal of Ethnic Studies 10, 3 (Fall 1982): 95109.

Okano, Haruko. Come Spring. Vancouver: Gallerie, 1992.

Okazaki, Robert K. The Nisei Mass Evacuation Group and P.O.W. Camp '101' Angler, Ontario, translated by Jean M. Okazaki and Curtis T. Okazaki. Scarborough, ON: n.p., 1996.

Okihiro, Gary. Cane Fires: The Anti-Japanese Movement in Hawaii, 1865-1945.

Philadelphia: Temple University Press, 1991.

Okihiro, Gary Y., and Joan Myers. Whispered Silences: Japanese Americans and World War II. Seattle and London: University of Washington Press, 1996.

Omatsu, Maryka. Bittersweet Passage: Redress and the Japanese Canadian Experience. Toronto: Between the Lines, 1992.

Onodera, Midi (Director). Displaced View. Toronto: Mcano Film Artists Inc., 1988. Film. Palmer, Howard. "Commentary." In On Guard for Thee, edited by Norman Hillmer, Bohdan Kordan, Lubomyr Luciuk, pp.233-240. Ottawa: Ministry of Supply and Services, 1988.

Palumbo-Liu, David. "The Politics of Memory: Remembering History in Alice Walker and Joy Kogawa." In Memory and Cultural Politics, edited by Amrijit Singh, Joseph T. Skerritt, Jr. and Robert E. Hogan, pp.21 l-226. Boston: Northeastern University Press, 1996.

Peck, Estelle Ishigo. Lone Heart Mountain. Los Angeles: Communicart, 1972.

Pierson, Ruth Roach. "They're Still Women After All": The Second World War and Canadian Womanhood. Toronto: McClelland and Stewart, 1986.

Rafiq, Fauzia, ed. Towards Equal Access: A Handbook for Service Providers Working With Survivors of Wife Assault. Toronto: Education Wife Assault, 1991.

Razack, Sherene. Canadian Feminism and the Law. Toronto: Second Story Press, 1991.

-. "Collective Rights and Women: 'The Cold Game of Equality Staring.' " The Journal of Human Justice 4, 1 (Autumn 1992): 1-11.

- Looking White People in the Eye. Toronto: University of Toronto Press, 1998.

-. "The Perils of Talking About Culture: Schooling Research on South and East Asian Students," Race, Gender and Class, 2,3 (Spring 1995): 67-82.

-. "Race, Space and Prostitution: The Making of the Bourgeois Subject." Canadian Journal of Women and the Law 10 (1998): 338-376.

-. "What is to Be Gained by Looking White People in the Eye? Culture, Race, and Gender in Cases of Sexual Violence." Signs, 19, 4 (Summer 1994): 894- 923.

Renan, Ernest. "What is a Nation?" In Nation and Narration, edited by Homi K. Bhabha, pp.8-22. London and New York: Routledge, 1990. 
Rogers, Kim Lacy. "Trauma Redeemed: The Narrative Construction of Social Violence." In Interactive Oral History Interviewing Edited by Eva M. McMahan and Kim Lacy Rogers, pp.31-46. Hillsdale, NJ: Lawrence Erlbaum Associates, 1994.

Roy, Patricia, and J.L. Granatstein, Masako lino, Hiroko Takamura. Mutual Hostages: Canadians and Japanese During the Second World War. Toronto: University of Toronto Press, 1990.

Said, Edward. Culture and Imperialism. New York: Alfred A. Knopf, 1993; New York: Random House, Vintage Books, 1993.

- Orientalism. New York: Random House, Pantheon Books, 1978; New York: Random House, Vintage Books, 1979.

Sakamoto, Kerri. The Electrical Field. Toronto: Alfred A. Knopf, 1998.

Scott, Joan W. "Experience." In Feminists Theorize the Political, edited by Judith Butler and Joan W. Scott, pp.22-40. New York and London: Routledge. 1992.

Shields, Rob. Places on the Margin: Alternative Geographies of Modernitv. London and New York: Routledge, 1991.

Shigekuni, Julie. A Bridge Between Us. New York: Doubleday, 1995.

Shikatani, Gerry. Selected Poems and Texts/Nineteen Seventy-Three. Toronto: Aya Press, 1989.

Shikatani, Gerry and David Aylward, eds. Paper Doors. Toronto: Coach House Press, 1981.

Shimizu, Yon. The Exiles: An Archival History of the World War II Japanese Road Camps in British Columbia and Ontario. Wallaceburg. ON: Shimizu Consulting and Publishing, 1993.

Shiomi, R.A. "Crossing Borders." Canadian Theatre Review 56 (Fall 1988): 16-19.

-. Yellow Fever. Toronto: Playwrights Union of Canada, 1984.

Shohat, Ella. "Sephardim in Israel: Zionism from the Standpoint of Its Jewish Victims." In Dangerous Liaisons, edited by Anne McClintock. Aamir Mufti, and Ella Shohat, pp.39-68. Minneapolis and London: University of Minnesota Press, 1997.

Simon, Roger I. "Forms of Insurgency in the Production of Popular Memories: The Columbus Quincentary and the Pedagogy of Counter-Commemoration." Cultural Studies 7,1 (January 1993): 73-88.

-. "The Pedagogy of Commemoration and Formation of Collective Memories." Educational Foundations 8, 1 (Winter 1994): 5-24.

Simon, Roger I. and Wendy Armitage-Simon. "Teaching Risky Stories: Remembering Mass Destruction Through Children's Literature.” English Quarterly 28, 1 (Fall 1995): 27-31.

Simon, Roger I. and Claudia Eppert. "Remembering Obligation: Pedagogy and the Witnessing of Testimony of Historical Trauma." Canadian Journal of Education 22, 2 (1997): 175-191.

Smith, Irene. "Hastings Park Hospital - Memories of Nurse Irene (Nee Anderson) Smith." The Bulletin 38, 4 (April 1996): 24.

Soja, Edward W. Postmodern Geographies: The Reassertion of Space in Critical Social Theory. London and New York: Verso, 1989.

Sone, Monica. Nisei Daughter. Seattle and London: University of Washington Press, 1982. Spelman, Elizabeth V. Inessential Woman. Boston: Beacon Press, 1988.

Spiegelman, Art. Maus: A Survivor's Tale. New York: Pantheon Books, 1986. 
Spivak, Gayatri Chakravorty. "Can the Subaltern Speak?" In Marxism and the Interpretation of Culture, edited by Cary Nelson and Lawrence Grossberg, pp.27 I313. Urbana and Chicago: University of Ilinois Press, 1988.

-. "Subaltern Talk." Interview by the editors of The Spivak Reader, edited by Donna Landry and Gerald Maclean, pp.287-308. New York and London: Routledge, 1996.

Stacey, Judith. "Can There Be a Feminist Ethnography?" In Women's Words: The Feminist Practice of Oral History, edited by Sherna Berger Gluck and Daphne Patai, pp.111-119. New York and London: Routledge, 1991.

Stasiulus, Daiva and Nira Yuval-Davis. "Introduction: Beyond Dichotomies - Gender, Race, Ethnicity and Class in Settler Societies." In Unsettling Settler Societies, edited by Stasiulus and Yuval-Davis, pp.1-38. London, Thousand Oaks, CA, and New Dehli: Sage Publications, 1995.

Stoler, Ann. Race and the Education of Desire. Durham and London: Duke University Press, 1995.

Stort, Merl. "The Sexual Reproduction of 'Race': Bisexuality, History and Racialization." In Queer Theory/Sociology, edited by Steven Seidman. Cambridge: Blackwell, 1996.

Sturken, Marita. Tangled Memories. Berkeley: University of California Press, 1997.

Sunahara, Ann Gomer. The Politics of Racism. Toronto: James Lorimer, 1981.

Suzuki, Aiko. Lyra (Fibre Suspension). Commissioned by the Metropolitan Toronto Reference Library, 1981.

Suzuki, Aiko, ed. About Japanese Canadians, Resource Listing III, revised by David Fujino. Toronto: Toronto Nikkei Archive and Resource Centre, 1996.

-, ed. Japanese Canadians in the Arts: A Directory of Professionals. Toronto: SAC/rist, 1994.

Suzuki, David. Metamorphosis. Toronto: General, 1988.

Szasz, Eva. Cherished Memories and Lost Years, written and narrated by Toshi Oikawa and Nobuko Oikawa. Montreal: National Film Board of Canada and National Museum of Man, 1980. Filmstrip, Filmstrip Notes, and Audiocassettes.

Tajiri, Rea (Director). History and Memory: for Akiko and Takashige. New York: Rea Tajiri, 1991. Film.

Takagi, Dana Y. "Maiden Voyage: Excursion into Sexuality and Identity Politics in Asian America." In Asian American Sexualities, edited by Russell Leong, pp.21-35. New York and London: Routledge, 1996.

-. "Personality and History: Hostile Nisei Women." In Reflections on Shattered Windows, edited by Gary Y. Okihiro, Shirley Hune, Arthur A. Hansen, John M. Liu. Pullman, WA: Washington State University Press, 1988, pp.184-192.

- The Retreat from Race: Asian-American Admissions and Racial Politics. New Brunswick, NJ: Rutgers University Press, 1992.

Takaki, Ronald. Strangers from a Different Shore. New York: Penguin, 1989.

Takashima, Shizuye. A Child in Prison Camp. Montreal: Tundra Books, 1971.

Takata, Toyo. Nikkei Legacy: The Story of Japanese Canadians from Settlement to Today. Toronto: NC Press, 1983.

Terr, Lenore. Unchained Memories. New York: Basic Books, 1994. 
Thomas, Dorothy Swaine, and Richard S. Nishimoto. The Spoilage: Japanese American

Evacuation and Resettlement. Berkeley and Los Angeles: University of California Press, 1946.

Toronto Star. Editorial: “Chrétien's Quips Inspire No Confidence.” 21 October 1998, p.A20.

Toronto Star. Editorial: “"We are the Israelites on the move." 20 November 1997, p.A28.

Trinh T. Minh-ha. Woman, Native, Other. Bloomington and Indianapolis: Indiana

University Press, 1989.

Uno, Kathleen S. "The Death of 'Good Wife, Wise Mother'?" In Postwar Japan as

History, edited by Andrew Gordon. Berkeley: University of California Press, 1993. pp. 293-322.

Von Hassel, Malve. "Issei Women: Silences and Fields of Power." Feminist Studies 19, 3 (Fall 1993), 549-569.

Wakayama, Tamio. Kikyo: Coming Home to Powell Street, oral histories edited by Linda

Uyehara Hoffman. Madeira Park, B.C.: Harbour Publishing, 1992.

Ward, W. Peter. The Japanese in Canada. Ottawa: Canadian Historical Association, 1982.

Watada, Terry. Bukkyo Tozen: A History of Jodo Shinshu Buddhism in Canada. Toronto:

HpF Press and the Toronto Buddhist Church, 1996.

- Daruma Days. Vancouver: Ronsdale Press, 1997.

Weedon, Chris. Feminist Practice and Poststructuralist Theory. Oxford: Basil Blackwell, 1987.

Weglyn, Michi. Years of Infamy: The Untold Story of America's Concentration Camps. New York: William Morrow, 1976.

Wheeler, Anne. Interview by Vicky Gabereau. Canadian Broadcasting Corporation Radio, 7 December 1995.

Wheeler, Anne (Director). The War Between Us. Canada: Atlantis Films Ltd./Troika Films Lid., 1995. Film.

Wiener, Nan and Morley Gunderson. Pay Equity: Issues, Options and Experiences. Toronto and Vancouver: Butterworths, 1990.

White, Hayden. "The Modernist Event." In The Persistence of History, edited by Vivian Sobchack, pp.17-38.. New York and London: Routledge, 1996.

Wong, Sau-ling Cynthia. Reading Asian American Literature. Princeton, NJ: Princeton University Press, 1993.

Yamada, Mitsuye. Desert Run: Poems and Stories. Latham, NY: Kitchen Table, Women of Color Press, 1988.

-. Camp Notes. San Lorenzo, CA: Shameless Hussy Press, 1976.

Yamamoto, Hisaye. Seventeen Syllables and Other Stories. Latham, NY: Kitchen Table, Women of Color Press, 1988.

Yeğenoğlu, Meyda. Colonial Fantasies. Cambridge: Cambridge University Press, 1998.

Yogi, Stan. "Yearning for the Past: The Dynamics of Memory in Sansei Internment Poetry." In Memory and Cultural Politics, edited by Amrijit Singh and Joseph T.

Skerritt, pp.245-264. Boston: Northeastern University Press, 1996.

Young, Charles and Reid, Helen R.Y. The Japanese Canadians. Toronto: University of Toronto Press, 1938. 
Government Documents: Published

Canada. British Columbia Security Commission, Removal of Japanese from Protected Areas. Vancouver: 1942.

Canada. Department of Labour, Re-Establishment of the Japanese in Canada: 1944-1946. Ottawa: 1947.

Canada. Department of Labour, Report on the Administration of Japanese Affairs in Canada: 1942-1944. Ottawa: 1944.

Canada. Department of Transport, Meteorological Division. Monthly Record Observations in Canada and Newfoundland, January 1943. Toronto: 1943.

Canada. Dominion Bureau of Statistics. Eighth Census of Canada, 1941, vol.3. Ottawa: 1946.

- Ninth Census of Canada, 1951, vol.10. Ottawa: 1956.

Canada. House of Commons, Debates. Ottawa: 1944.

Canada. Statistics Canada. Census 1991, Ethnic Origin. Ottawa: 1993.

Canada. Statutes of Canada, 1914, 5 Geo.V. c.2.

\section{National Archives of Canada, Ottawa}

\section{Government Records}

National Archives of Canada (hereafter NA), Records of the Department of External Affairs, RG 25.

NA, Records of the British Columbia Security Commission, RG 36/27.

Manuscript Collections

NA, Muriel Fujiwara Kitagawa Papers.

Special Collections and University Archives Division, University of British Columbia Library, Vancouver

University of British Columbia Aural History Transcripts, 76-1, Mrs. Ellen Enemoto, 16 May 1972

\section{Interviews}

Interview by the Author

Ann [pseud.]. Tape recording. 1 November 1995.

Aya [pseud.]. Tape recording. 26 August 1996.

Eiko [pseud.].Tape recording. 30 November 1995

Esther [pseud.].Tape recording. 17 August 1995.

Evelyn [pseud.]. Tape recording. 26 August 1995.

Haru [pseud.] Tape recording. 23 November 1995. 
Irene [pseud.] Tape recording. 16 June 1995.

Janice [pseud.]. Tape recording. 23 August 1995.

Joanne [pseud.]. Tape recording. 31 October 1995.

Kazuko [pseud.]. Tape recording. 19 October 1995.

Kyo [pseud.]. Tape recording. 30 June 1995.

Louise [pseud.]. Tape recording. II July 1995.

Margaret [pseud.]. Tape recording. 20 June 1995.

May [pseud.]. Tape recording. 24 March 1992.

Mayumi [pseud.]. Tape recording. 1 November 1995.

Midori [pseud.]. Tape recording. 24 August 1995.

Naomi [pseud.]. Tape recording. 31 December 1994.

S. [pseud.]. Tape recording. 16 August 1995.

Sylvia. [pseud.]. Tape recording. 29 September 1996.

Yuko [pseud.]. Tape recording. 6 November 1995.

Yoshiko [pseud.]. Tape recording. 22 December 1994. 